\author{
UNIVERSIDADE DE SÃO PAULO \\ FACULDADE DE FILOSOFIA, LETRAS E CIÊNCIAS HUMANAS \\ DEPARTAMENTO DE GEOGRAFIA \\ PROGRAMA DE PÓS-GRADUAÇÂO EM GEOGRAFIA HUMANA
}

MARCO ANTONIO TEIXEIRA DA SILVA

A metrópole antitética: a relação capital-espaço e a expropriação no Pantanal da Zona Leste

São Paulo

2015 


\author{
UNIVERSIDADE DE SÃO PAULO \\ FACULDADE DE FILOSOFIA, LETRAS E CIÊNCIAS HUMANAS \\ DEPARTAMENTO DE GEOGRAFIA \\ PROGRAMA DE PÓS-GRADUAÇÂO EM GEOGRAFIA HUMANA
}

\author{
MARCO ANTONIO TEIXEIRA DA SILVA
}

\title{
A metrópole antitética: a relação capital-espaço e a expropriação no Pantanal da Zona Leste
}
Tese apresentada ao Programa de Pós-Graduação em Geografia Humana do Departamento de Geografia da Faculdade de Filosofia, Letras e Ciências Humanas da Universidade de São Paulo para a obtenção do título de Doutor em Geografia

Área de Concentração: Geografia Humana

Orientadora: Professora LivreDocente Amélia Luisa Damiani

São Paulo 
Autorizo a reprodução e divulgação total ou parcial deste trabalho, por qualquer meio convencional ou eletrônico, para fins de estudo e pesquisa, desde que citada a fonte.

Catalogação na Publicação

Serviço de Biblioteca e Documentação

Faculdade de Filosofia, Letras e Ciências Humanas da Universidade de São Paulo

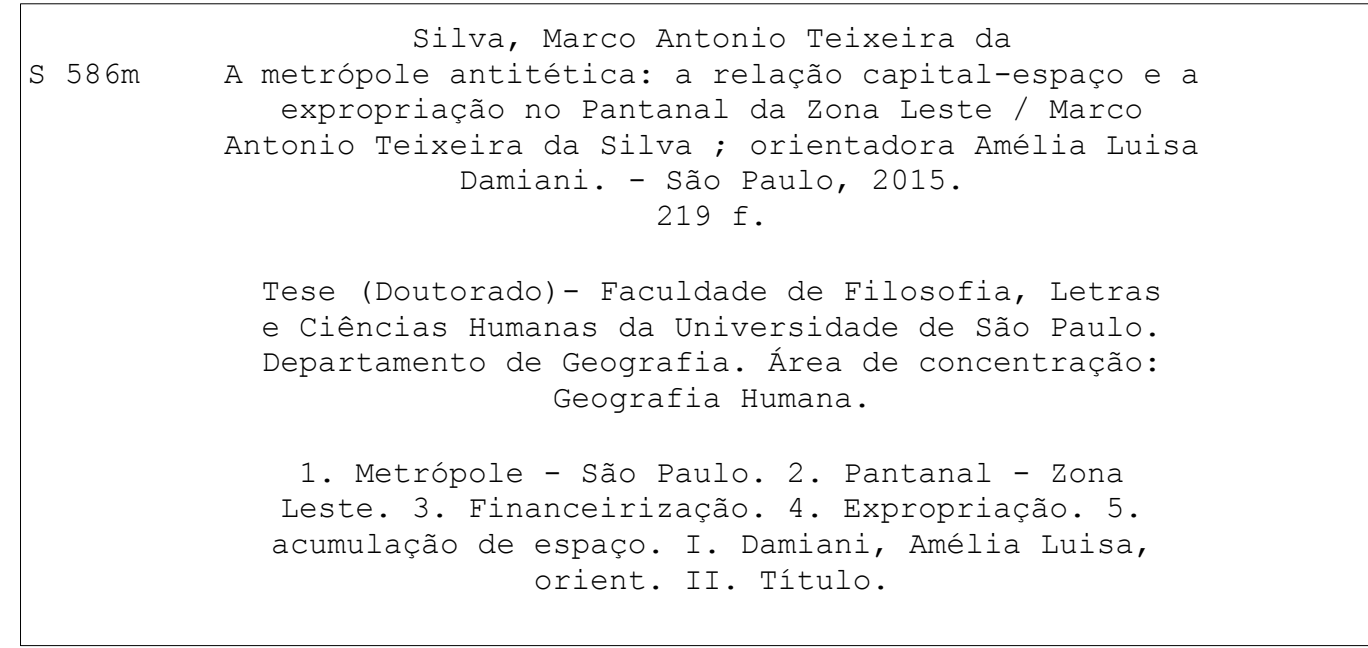


Nome: SILVA, Marco Antonio Teixeira da

Título: A metrópole antitética: a relação capital-espaço e a expropriação no Pantanal da Zona Leste

Tese apresentada ao

Departamento de Geografia da

Faculdade de Filosofia, Letras e

Ciências Humanas da Universidade

de São Paulo para a obtenção do

título de Doutor em Geografia

Aprovado em:

Banca Examinadora

Prof. Dr. Instituição:

Julgamento: Assinatura:

Prof. Dr. Instituição:

Julgamento: Assinatura:

Prof. Dr. Instituição:

Julgamento: Assinatura:

Prof. Dr. Instituição:

Julgamento: Assinatura:

Prof. Dr. Instituição:

Julgamento: Assinatura: 
Este trabalho intenta elucidar a negação do urbano às populações empobrecidas. $\mathcal{A}$ elas dedico esta infima obra em nome do direito à cidade. 


\section{Agradecimentos}

Uma tarefa difícil lembrar todas e todos que participaram direta e indiretamente da produção desta tese. Agradeço sinceramente por estarem comigo nesta caminhada.

Ao colega Vitor, do curso de Geografia, pelos primeiros contatos que me levaram ao Pantanal. Igualmente à Sirena, também por ter me colocado em contato com Oswaldo. Aos trabalhadores do Instituto Alana, principalmente Oswaldo pelos materiais fornecidos, pelos diálogos e por me abrir as portas para participar dos Fóruns do Pantanal. Aos integrantes do Movimento de Urbanização e Luta pelo Pantanal (MULP), principalmente Wagner e Zélia, pelos diálogos esclarecedores e materiais fornecidos. Ao Ronaldo Delfino, pelo também esclarecedor diálogo. Ao Núcleo de Habitação e Urbanismo da Defensoria Pública do Estado de São Paulo, principalmente o Defensor Bruno Miragaia. A todos os moradores e integrantes de instituições que participaram dos fóruns do Pantanal.

Aos colegas Alexandre (com saudades), Evânio, Ricardo, Flávia, Bruno, Cauê, Felipe, Luciano, Jean, Cleuza, especialmente ao Marcinho, e todos que colaboraram e colaboram com o Grupo de Estudo sobre Alienação, no qual uma parte significativa de minha formação aconteceu. À Professora, Coordenadora deste Grupo e também Orientadora desta Tese Amélia Damiani, pela afetividade, pelo conhecimento proporcionado e pela paciência. À Professora Odette Seabra, com quem iniciei esta caminhada há muitos anos atrás.

Aos amigos e vizinhos queridos, sempre muito solidários, Ana e Rinaldo, muito obrigado pela ajuda no mapa e em tantas outras ocasiões.

Aos amigos Vera, Reginaldo, Luciane, Marilisa, Dalmo, Sueli, Rita, Leno, Edeli, Maizza, Davi, Gleice, Xico, Adriana, Mario, Pri e os filhos, Lúcia, Simone, Humberto, Débora, Dani, Scarin, Bily, Laercio, Toninho, Mimi, Fernanda, Carol e a tantos outros, todos os que aqui estão comigo, sempre estiveram, nos risos, nas lembranças, nos momentos os mais diversos dessa trajetória. 
À minha família, Dona Elisa, Sr. Jose, meus pais amados; Tania, minha irmã de sangue e de fé; Reverson e Ju, sobrinhos queridos que me presentearam com a surpresa de ser tio-avô e padrinho dessa maravilhosa criança, minha sobrinha-neta Emilly.

À minha outra família, Laercio, Marcia, Olivia, e todos os filhos, primos, tios, sobrinhos, que me acolheram, é tudo mano parente.

À minha amada, meu amor, minha Isis, a mesma parte de mim.

A todas(os), muito obrigado. 


\section{Resumo}

Esta pesquisa considera a problemática da área denominada Pantanal da Zona Leste, região situada no leste da cidade de São Paulo que corresponde às várzeas do rio Tietê. A partir da institucionalização dos atributos ambientais na forma do Parque Várzea do Tietê se estabelece o conflito para a remoção dos moradores. Tal conflito permite analisar as condições da reprodução contemporânea baseada na relação capital-espaço. Sob a aparência do ambientalismo e da sociedade do risco, as instituições estatais e privadas operam a produção do espaço de modo que os atributos da "sustentabilidade social" se sobreponham ao vivido ali constituído. Por décadas, a reprodução de populações empobrecidas refletia o cotidiano espoliado em espaços infraurbanos. As metamorfoses da reprodução contemporânea impõem outra lógica para estas populações, uma vez que o espaço torna-se elemento estrutural da reprodução, esta que se relaciona à financeirização de maneira cada vez mais intensa. Assiste-se então a uma acumulação de espaço como centralidade do processo, pela possibilidade de inversões de capital para remuneração financeira, esta que, para o caso aqui estudado, torna-se dívida pública. Há, portanto, uma nova condição para a reprodução dos pobres na metrópole, que é a sua expropriação como meio para se atingir a acumulação de espaço. Tais processos se concretizam, mas o fazem de maneira velada, por meio das representações do espaço, a forma socialmente aceita que culmina nos espaços de representação como realização de todo um processo que define a reprodução contemporânea de maneira antitética, "não há urbano para todos".

Palavras-chave: metrópole antitética, financeirização, relação capital-espaço, acumulação de espaço, expropriação, Pantanal da Zona Leste. 


\section{Abstract}

This research considers the problem of the area called East Zone Pantanal, a region situated in the eastern city of São Paulo that corresponds to Tietê River floodplains. From the institutionalization of environmental attributes in the form of Tietê Várzea Park establishes the conflict for the removal of the residents. Such conflict allows analyze the conditions of contemporary reproduction based on capital-space relationship. Under the guise of environmentalism and the risk society, the state and private institutions operate the production of space so that the attributes of "social sustainability" superimposing to been lived there constituted. For decades, the reproduction of impoverished populations reflected the quotidian despoiled in infraurban spaces. The metamorphosis of contemporary reproduction impose other logic for these populations, as space becomes structural element of reproduction, this one is related to financialization more and more intense. We are witnessing an accumulation of space as the centrality of the process, the possibility of capital investment for financial remuneration, this one, in case studied here, becomes government debt. There is therefore a new condition for the reproduction of the poor in the metropolis, which is them expropriation as a means to attain the space accumulation. Such processes are concretized, but they do so in a veiled way, through the representations of space, the mode socially accepted that culminates in the spaces of representation as the realization of a whole process that defines the contemporary reproduction of antithetical mode, "there is no city for everyone ".

Keywords: antithetical metropolis, financialization, capital-space relations, space accumulation, expropriation, East Zone Pantanal. 


\section{Sumario}

Introdução 11

Parte 1 - Elementos Teóricos para a Análise do Espaço 23

Capítulo I

A Produção Desigual do Espaço na Reprodução Capitalista 24

Capítulo II

O Movimento Crise-Acumulação e o Processo de Financeirização 39

Capítulo III

A Financeirização na Relação Capital-Espaço 54

Capítulo IV

A Relação Capital-Espaço em Relação à Propriedade-Expropriação 65

Parte 2 - Metropolização 83

Capítulo V

Espaço e Relações Sociais na Metropolização de São Paulo 84

Capítulo VI

Periferização 98

Capítulo VII

Metamorfoses nas Relações Socioespaciais 108

Capítulo VIII

Rios e Várzeas na Metropolização de São Paulo 123

Parte 3 - Pantanal 139

Capítulo IX

As Várzeas do Pantanal na Lógica da Financeirização 140

Capítulo X

O Pantanal em Si 163

Conclusão 209 
Bibliografia

Apêndice:

Mapa 1 - Localização do Parque Várzea do Tietê, Sistema Viário Metropolitano e Barragens do Alto Tietê

Mapa 2 - Mapa detalhado do Sistema Viário Metropolitano

Anexos:

Anexo 1 - Folheto Operação Defesa das Águas

Anexo 2 - Perímetro do Parque Várzea do Tietê (Departamento de Águas e Energia do Estado de São Paulo - DAEE)

Anexo 3 - Relatórios do Banco Interamericano de Desenvolvimento (BID) sobre a Operação BR-L1216 (Parque Várzea do Tietê)

Anexo 4 - Mapa das Remoções 
Introdução 
As perspectivas da análise geográfica passaram por significativas transformações ao longo da própria historia de Ciência Geográfica. Tal como aconteceu em outros momentos, nos vemos atualmente num debate a respeito não propriamente das questões epistemológicas da Geografia, embora se incluam nesse escopo como necessárias às novas análises, mas num amplo embate teórico que abarca variados campos do conhecimento a respeito das complexas metamorfoses pelas quais a reprodução capitalista contemporânea vem passando. A complexidade de relações predispostas mundialmente por processos que simultaneamente produzem uma exponencial acumulação contraposta a uma iminente crise aponta para um momento marcado pela profunda negatividade do processo em si, uma implosão-explosão deste, cujo devir se nos apresenta tão sombrio como as contradições que dele emergem, como que vindas de uma fantasmagoria profunda lançada sobre toda a sociedade.

Em meio a uma incrível produtividade industrial que se desenvolve a partir de relações cada vez mais profundas com a ciência e a tecnologia, dinamizando a relação tempo-espaço numa escala cada vez mais mundial e infinitesimal, emergem condições cada vez mais precárias de trabalho que envolvem enormes contingentes. Por outro lado, o dinheiro se multiplica de maneira exponencial, em dívidas, em títulos, em depósitos, em fortunas e em muita miséria. Torna-se a forma pura e definitiva de uma sociedade calcada em relações abstratas. Mas, ao mesmo tempo em que aquele se multiplica, o faz de maneira fictícia. Guardar esta ficção, cuidar para que permaneça e se multiplique parece ser a lógica conduzida por alguns para o sacrifício dos outros.

Uma primeira consideração que surge como objeto desta pesquisa é a de que a produção do espaço urbano na atualidade reflete tais processos. A escala de análise pressupõe um movimento geral da reprodução capitalista, que daqui por diante tratarei apenas por reprodução, num espaço urbano particular, este que explicava-se primordialmente a partir de um duplo processo urbanização-industrialização que, me parece, pressupõe agora novas análises. A Metrópole de São Paulo desde o século XIX se constituiu a partir desse duplo urbano-industrial, o que configurou uma vasta região caracterizada predominantemente em sua formação por um duplo relacional que se 
convencionou conceituar centro-periferia. Na atualidade percebe-se que novos processos se inserem para explicar a dinâmica da produção do espaço urbano nessa metrópole. A partir de tal premissa, surgem alguns questionamentos que norteiam os objetivos desta pesquisa. Num primeiro momento, cabe refletir então quais seriam as novas condições da produção do espaço na metrópole paulistana diante de transformações estruturais as quais redefinem as formasconteúdo urbanas. Por outro lado, torna-se primordial entender quais os nexos que nos permitem relacionar tal produção às novas condições para a reprodução do capital contemporaneamente, de tal maneira que se faz necessário repensar os processos socioespaciais a partir de outras lógicas que operam nas relações sociais e no espaço urbano de maneira a possibilitarem os novos termos dessa reprodução, sobretudo a partir de uma lógica financeira.

Diante disso, me propus a analisar as novas formas da produção do espaço a partir da região denominada Pantanal da Zona Leste, situada nas planícies fluviais do rio Tietê na porção leste da Metrópole de São Paulo, onde se encaminha a definição de uma área protegida denominada Parque Várzea do Tietê. Num primeiro momento, a aproximação com a temática da apropriação dos rios e das várzeas na formação da metrópole de São Paulo permitiu-me analisar ao longo de minha trajetória acadêmica os processos que fundamentaram a constituição desses ambientes fluviais em forças produtivas da urbanização, mas que revelaram também profundas contradições nesse processo. Os eventos ocorridos no verão 2009/2010, com a inundação da região que, em algumas áreas chegou a sessenta dias, me chamou a atenção como um possível campo de investigação. Por outro lado, a construção do referido Parque e as formas pelas quais esta relaciona mecanismos mundiais de financiamento com formas de expropriação dos moradores me levaram a pensar se nesse processo haveria então a relação entre a produção do espaço urbano e a reprodução capitalista contemporânea, ou melhor, se por este exemplo poderíamos elucidar algumas das formas contemporâneas desta relação que denomino capital-espaço?

A problemática na região do Pantanal da Zona Leste é a da regulamentação dos chamados atributos ambientais, propriamente a planície fluvial do rio Tietê a montante e jusante dos trechos percorridos pelas Avenidas Marginais do Tietê, na forma de zonas de proteção nas quais não se permite 0 
estabelecimento de moradias. A justificativa para a intervenção se baseia na localização destas no ambiente fluvial das várzeas ${ }^{1}$, sob o argumento de que tal condição implica num impacto ambiental por tratar-se de formas de ocupação que, ao modificarem os fatores do escoamento superficial, tornam-se potencializadoras das inundações do rio Tietê, tanto na área pesquisada como a jusante, no trecho que corresponde ao trajeto das vias Marginais Tietê. Nestes termos, tal regulamentação é justificada também pela preservação da "qualidade de vida" dos próprios moradores envolvidos na problemática, uma vez que se situam em áreas consideradas de "risco", além de a possibilidade de remoção ser considerada como uma condição de acesso à "moradia digna" por inclui-los em programas sociais de reassentamento. Diferentes níveis se articulam neste e por este espaço, ao abarcar dimensões que envolvem o ambiente fluvial das várzeas na sua condição institucionalizadainstitucionalizante, perpassam o cotidiano das populações envolvidas e se realizam também nas esferas mundializadas do capital financeiro.

Nestes termos, entendo que a área de estudo desta pesquisa, o Pantanal da Zona Leste em São Paulo, se insere no espaço da metrópole como um lugar especificamente definido a partir de sua institucionalização como condição própria da reprodução do capital financeiro. As condições institucionais propostas que produzem este espaço o tornam potencial para a financeirização, mas o fazem num contexto histórico definido a partir da relação capital-espaço como relação primordial ditada pelas metamorfoses contemporâneas na reprodução do capital em geral. Neste processo, o cotidiano de seus moradores se expressa como negação, tanto nas condições objetivas como subjetivas, na maneira como estes vivem e percebem o espaço urbano.

Elaboro então um desenvolvimento teórico que põe o espaço como elemento central da reprodução contemporânea. Mas este não é puramente físico, concreto, ou algo que serve de suporte para os objetos, e sim que se

\footnotetext{
${ }^{1}$ Daqui por diante trato por várzeas as áreas correspondentes à planície fluvial. Me defino por este termo como conceito, aquele que foi desenvolvido e incorporado no cotidiano de uma população que historicamente produziu modos de vida ligados aos rios e as várzeas a partir de saberes constituídos na relação com estes ambientes. Não se trata, portanto, de um termo, mas de um conhecimento desenvolvido ao longo de séculos que permitiu tanto a incorporação desses ambientes em termos mercadológicos, pela apropriação privada de suas frações minerais, como sua apropriação coletiva em temos lúdicos.
} 
define nas e pelas relações sociais historicamente constituídas, estas que revelam a metrópole num conjunto concreto e abstrato, ou de outro modo, de abstrações concretas no interior do movimento categorial que põem e opõem os termos da reprodução capitalista. Procuro transcender o espaço como objeto concreto e pensar nas relações sociais ${ }^{2}$ que aqui se constituem em diferentes níveis que se põem como condição do espaço enquanto realização destas mesmas relações, que envolvem o próximo e o distante, território no qual se confrontam o cotidiano dos moradores, as necessidades de realização das esferas financeiras mundializadas do capital e o Estado como poder político e regulador dessa realização. Portanto, entendo que o Pantanal da Zona Leste significa mais do que nomear a área de abrangência de um projeto de demarcação territorial da legislação ambiental. Possibilita-me pensar, a partir das relações sociais ali desenvolvidas, o processo de produção do espaço e seus vínculos com a reprodução contemporânea.

Desenvolvo a produção do espaço como exterior e interior ao individuo, à sociedade mesma, como dimensão objetiva e que se constitui também subjetivamente, ao operar o desejo, o corpo, a sociabilidade, ao produzir, difundir e fazer se incorporar os "valores sociais" enquanto verticalidades ${ }^{3}$ oriundas de um processo geral da economia mundializada. Pensar as relações da produção do espaço que se interpõem aos grupos sociais é, como nos propõe Amélia Damiani (2008), inverter a teoria do espaço como suporte social, pensar a produção do espaço no interior de uma concepção crítica da economia política do espaço. Para esta autora metamorfosear a ciência do espaço, realizada enquanto lógica formal, à produção do espaço, como compreensão dialética.

\footnotetext{
2 Tratamos aqui das relações sociais de produção como integradas ao movimento de reprodução do capital em geral e por ele (re)definidas. Claro que as relações sociais não se resumem a este processo e são definidas também nos interstícios deste, se realizam naquilo que é próprio do humano, como singularidades que envolvem relações afetivas, de proximidade, de reconhecimento e, nos conflitos gerados pela sua inserção na reprodução do capital em geral, tornam-se residuais, posto que conservam a centelha da constituição da humanidade e do humano.

${ }^{3}$ Nos trabalhos de Milton Santos, este termo torna-se conceitual e se define por aquilo que é próprio do que o autor chama de economia globalizada, suas determinações formais enquanto processo realizado nas esferas e corporações empresariais e que se territorializam como condição de objetivação dessas formas econômicas, fenômeno este que vem "de cima para baixo", definido nas altas cúpulas das empresas globais, agentes transformadores dos lugares e mesmo regiões, enfim transformadores daquilo que autor chama de "espaço banal". Ver SANTOS, 2002
} 
Ser o espaço, nesse entendimento, o pressuposto estrutural da atual reprodução não significa que por ele se encaminhe a condição total da análise. Ao se conformar uma leitura de superfície sobre a qual se situam objetos incorre-se no equívoco da forma pura, uma vez que as categorias de análise se movem no processo histórico pressupostas por relações sociais as quais se definem enquanto forma-conteúdo e permitem ver a negatividade do processo posto pelas abstrações concretas, pela análise no interior do processo e não em sua superfície. Isso se explica pela condição de superar o espaço enquanto representações, as quais se movem no conjunto das relações socioespaciais de maneira a obscurecer a análise e tanto criar como sustentar discursos que se tornam objetivações como espaços de representação.

Subjetivamente, as representações do espaço, as ideologias como, por exemplo, o ambientalismo, os mecanismos de coerção postos pelos desvios em relação às médias sociais, tudo isso se conforma numa racionalidade, numa maneira de se pensar e de ser pensado, de se ver e ser visto num contexto social de aceitação, a partir do que podem operar as formas de recriminação, de culpa, de aceitação da institucionalidade como forma possível de regulação social e de inserção nessa regulação. Situados nas novas condições de reprodução do capital, a vida se expressa como incerteza, como impossibilidade, que daí resulta viver o urbano como pura negatividade (DAMIANI, 2000) $)^{4}$.

Tais representações velam pela manutenção da expropriação ${ }^{5} \mathrm{e}$ precisam ser dissipadas pela análise. A compreensão passa pela necessidade de pensar no ambientalismo e no risco social como potências reguladoras

\footnotetext{
${ }^{4}$ No artigo em questão, Amélia L. Damiani expõe uma trajetória de pesquisa que revela o cotidiano das populações por ela pesquisadas vivendo as múltiplas relações na metrópole definidas pela perda, ausência, precarização, que envolvem as formas de trabalho, moradia, organização social.

5 Digo expropriação porque, mesmo sem a propriedade de fato, jurídica, a moradia está estabelecida há muitos anos na área de estudo, em alguns casos, há mais de três décadas. $O$ tempo não importa necessariamente. O que define este termo, expropriação, é propriamente antítese da apropriação, as bases do acesso desses moradores a uma porção do espaço metropolitano como realização da moradia, ou seja, a posse da terra mesmo em condições específicas de mercantilização, como é o caso das ocupações que formam um mercado particular sem a condição jurídica da propriedade, assim como as próprias ocupações como forma de acesso a esta porção do espaço. A despossessão (HARVEY, 2004) seria a perda do terreno, desta porção da superfície terrestre. Já a expropriação seria a negação da apropriação do espaço, o qual não se resume ao terreno, à posse em si, mas uma iminente perda do urbano, para o urbano, como nos sugere Henri Lefebvre em alguns de seus trabalhos, cujo espaço urbano e a apropriação se fundem na vida cotidiana como movimento positivo e negativo. Ver LEFEBVRE, 1999; 2001.
} 
territoriais, ideologias e práticas a partir das quais se configuram novas estratégias de produção do espaço relacionadas às formas financeiras do capital. O planejamento urbano permanece como instrumento de poder sobre o espaço, agora munido das técnicas e engenharias que consideram-no a partir do conhecimento científico que calcula e define os atributos ambientais necessários à sua regulação, também a partir da subjetividade, ao difundir e incorporar significações sociais, que nesta pesquisa trato por representações do espaço. São muitas as suas formas que aparecem nas médias sociais. Propagam as definições da "qualidade de vida" como possibilidade a ser alcançada socialmente pela incorporação de populações empobrecidas aos elementos estruturais da vida contemporânea, como são os indicadores socioambientais, como é também o acesso, pela via da institucionalização e mercantilização, à propriedade privada do solo urbano. A forma pura desta estratégia é o espaço de representação, o devir pressuposto pelas atuais condições da reprodução capitalista.

No campo teórico-metodológico, proponho uma analise a partir das categorias historicamente constituídas da formação capitalista, mas numa condição histórica particular que foi a metropolização em São Paulo. Acredito que há aqui uma chave de interpretação para o desvendamento da relação capital-espaço. A interpretação da categoria espaço como objetivação das relações sociais de produção torna-o imanência dessas relações, o qual se produz de maneira desigual explicada no interior das contradições categoriais, como são o trabalho e a propriedade. Retomar este processo, a metropolização, se faz necessário para localizar de que maneira os momentos dessa reprodução podem explicar as condições contemporâneas que assume o espaço na reprodução capitalista.

Ao pensar a metrópole como fenômeno da modernidade, cujo processo de reprodução se move pelas condições de realização do capital em geral, esta se apresenta como positividade, pois que nela se concentram as forças produtivas sociais, as condições para a divisão do trabalho, a técnica, o próprio espaço como mercadoria; e como negação que, por suas contradições internas, torna cada vez mais complexa a realização do capital, configurando metamorfoses nas relações sociais de produção definidoras das objetivações espaciais enquanto momentos dessas contradições. Nessas condições, sua 
produção histórica, a metropolização, move-se em meio às contradições internas, ao produzir e reproduzir o cotidiano de seus moradores como relações sociais de produção, identitárias e ao mesmo tempo antitéticas ao se defrontarem à reprodução do capital. Identitárias, pois que relacionam historicamente a produção social com a reprodução do capital. Antitéticas porque redefinem a própria reprodução posta pelas contradições internas nas relações sociais de produção. Neste aspecto, tornam-se expropriação. A moradia possível de outros tempos torna-se impossível pelas novas condições requeridas para a realização do capital, que "varre" o espaço de seus incômodos para redefini-lo sob suas determinações formais. Transfigura-se a forma, mas que esta, ao ser penetrada por relações abstratas, revela-se como conteúdo. Neste contexto, o urbano se afirma como condição de reprodução do capital, ao mesmo tempo em que se nega como expressão do cotidiano dos moradores. Neste e por este processo é que a razão instrumental associada às ideologias ganha significado, produzem espaços de representação.

Proponho numa escala mais aproximada ao cotidiano uma situação geográfica, uma relação espaço-tempo-lugar na qual se confrontam diferentes níveis e dimensões ${ }^{6}$ e relacionam o ambiente fluvial das várzeas às formas sociais postas e dispostas pela modernização em São Paulo. Há, portanto uma premissa teórica que relaciona o processo geral de reprodução ao processo particular da fragmentação da metrópole de São Paulo, à compreensão do que foi a inserção desses espaços na modernização dentro dos quais a análise das relações sociais permitem a leitura da textura social e suas objetivações socioespaciais como processos que incorporam as categorias básicas da formação histórica capitalista, mas o fazem sob contextos e práticas sociais particulares.

A institucionalização do espaço como pressuposto das transformações em seus usos objetivados, como no caso do Pantanal, de remoção das moradias da área de proteção permanente, é pressuposto de novos arranjos

\footnotetext{
${ }^{6}$ Henri Lefebvre propõe como análise do espaço a ação de diferentes níveis e dimensões que se definem no e pelo espaço a partir de relações que variam das mais abstratas, por exemplo, no nível do Poder, do Estado e das estruturas privadas por este dinamizado a partir das sóciológicas pressupostas pelo que o autor chama de neodirigismo, passando pelo nível "especificamente urbano", no qual se relacionam os lugares e as instituições, e o nível mais particular definido pelas relações habitar-habitiat, condicionadas pela escala da prática cotidiana, mas tensionada pelas abstrações mundializadas (LEFEBVRE, 1999 p. 77-98).
} 
espaciais como possibilidade das inversões de capital na forma financeira. Dizer uso objetivado não significa que o uso e a apropriação estejam no mesmo escopo jurídico, o da propriedade. Na metropolização de São Paulo este processo torna-se primordial para uma leitura contemporânea da produção do espaço. Longe do amparo da ordem jurídica, ao mesmo tempo em que esta modifica seu conteúdo, se apresenta uma parcela significativa do espaço urbano de São Paulo como acumulação de espaço, um espaço possível e passível de ser transfigurado em outro, de ser redefinido por novas formas de uso e, portanto, de ser expropriado.

Relaciono nessa análise diferentes momentos da metropolização para alcançar o entendimento da produção desigual do espaço e refletir sobre a metrópole como antitética. A partir da periferização como expediente da reprodução da força de trabalho, vai se constituindo internamente à metrópole um espaço que simultaneamente produz e é produzido pela acumulação e pela espoliação. Essa produção desigual traz para a reflexão contemporânea o preceito da acumulação de espaço tornada estratégica para as intervenções atuais na metrópole pela via da expropriação.

Esses espaços acumulados ao longo da metropolização em São Paulo apresentam-se como espaços potenciais de grandes obras futuras, bases reais dos processos que se situam no centro da crise-acumulação capitalista contemporânea $^{7}$, como afirmação desta mesma crise. Transforma-los em espaços institucionais definidos como áreas de proteção ambiental explicam e são explicados por este processo, como potenciais "congelados" (termo muito usado nos dizeres jurídicos), reservas no aguardo das inversões financeiras. $E$ são principalmente os espaços empobrecidos da metrópole os que sustentam tais condições, não como acaso, mas por diversas características que favorecem as ditas ações de desapropriação e desocupação, ou como se diz na linguagem instituída da sociedade de risco, "desfazimento". À dinâmica socioespacial das populações empobrecidas na metrópole se contrapõem as definições jurídicas do espaço, principalmente aquelas que dizem respeito à

\footnotetext{
7 HARVEY (2004, cap. 4) trabalha os pressupostos da sobreacumulação como momento necessário à compreensão da produção do espaço contemporâneo. Em minhas considerações, há sempre acumulação e crise simultâneas.
} 
propriedade privada do solo urbano como fundamento das formas de expropriação, conteúdo mesmo que se situa no movimento capital-espaço.

Por outro lado, essa metropolização carrega consigo um significado modernizador, premente de atualizações tecnológicas que propugnam 0 pertencimento a um processo dinamizado pelo progresso aliado à técnica e à engenharia como elementos estruturantes da prática social. Essa lógica revela momentos da inserção de São Paulo na modernização pela via, por exemplo, da produção e distribuição de energia elétrica em fins do século XIX feitas por relações de concessão pactuadas entre o Governo da Província à época e a Concessionária Cia. Light \& Power S/A. Os elementos de natureza originária da Bacia Sedimentar de São Paulo, particularmente os ambientes fluviais, passam a ser apropriados e consumidos de maneira privada, transformados em forças produtivas da sociedade como socialização privada. Tornam-se eles mesmos elementos da metropolização como significado do moderno, seja como energia hidroelétrica ou como espaços de circulação viária. Dessa prática se objetiva em São Paulo um complexo "sistema hidrotécnico" que corresponde ao Alto Tietê, composto por barragens, elevatórias, transposições e até a reversão do rio Pinheiros. A operação desse sistema permite regular vazões em pontos específicos da drenagem do Alto Tietê. Entender esse funcionamento e acompanhar essa história tem sido parte de minha formação. Importa-me aqui relacionar a produção desse sistema com a metropolização, pois a problemática do Pantanal da Zona Leste relaciona-se diretamente a essa história.

O percurso desta pesquisa não foi linear. Da mesma maneira que nos ambientes fluviais da várzea do Tietê, foi um percurso meândrico, cuja ideia inicial era uma aproximação ao cotidiano dos moradores, às não menos meândricas tramas que envolvem a condição de habitar espaços declarados institucionais e requeridos pelos poderes políticos, tornados assim espaços conflituosos ao confrontarem moradores e instituições na luta por um pedaço da superfície terrestre, ao exporem a contradição entre espaço e lugar. Ao

\footnotetext{
${ }^{8}$ Este conceito foi elaborado por Vandeli Custódio em seus estudos sobre as inundações em São Paulo ao incorporar as ideias de Milton Santos, dos sistemas técnicos, aliadas á apropriação do sistema hidrográfico do Alto Tietê. Ver: Vanderli CUSTÓDIO: A Persistência das Inundações na Grande São Paulo. Tese de Doutorado. São Paulo, Universidade de São Paulo, 2002.
} 
participar de alguns fóruns organizados por entidades ligadas à luta dos moradores na região do Pantanal, como o Instituto Alana, com a presença de instituições privadas e do Estado, fui percebendo a complexidade do processo, ao mesmo tempo em que elementos estruturais dessa relação se apresentavam. Não pela complexidade das relações envolvidas, mas pelas minhas dificuldades em relação a tempo e espaço, tomei rumos mais teóricos no desenvolvimento da pesquisa. Entendi ser este um caminho razoável, uma vez que não teria fôlego para uma aproximação mais efetiva ao cotidiano dos moradores. Penso ser essa discussão teórica algo que contribua para a construção de um debate geográfico a respeito das mudanças que perpassam a reprodução contemporânea. De qualquer maneira, o entendimento de como se encaminham as formas de expropriação no Pantanal são relevantes para se chegar à produção do espaço, pois esta confronta diretamente moradores e instituições tanto de maneira objetiva como subjetiva. Por trás de relações que aparecem como diretas, se apresentam outras que escapam às análises objetivas e operam por construções simbólicas. A construção teórica desse entendimento como meio para chegar até uma compreensão epistemológica de nível mais geral passa necessariamente pela experiência cotidiana. Dessa forma, me apoiei na experiência dos fóruns de discussão ao longo do ano de 2012, assim como na coleta de alguns depoimentos. Também me apoio em alguns documentos institucionais que considero relevantes, e que eram os até então produzidos pelas instituições.

Importantíssimo ressaltar que não se trata aqui de fazer juízo de bem ou mal, até porque na fala dos moradores está claro que "ninguém gosta de morar numa situação como esta"” (praticamente não há infraestrutura, luz, água, asfalto, saneamento, além da insalubridade do ambiente fluvial). O que se pretende é entender as formas contemporâneas da reprodução capitalista no espaço metropolitano a partir da combinação de sua produção desigual com formas financeiras alimentadas pelas ideologias que tornam potentes as formas de expropriação das populações empobrecidas da metrópole paulistana.

\footnotetext{
${ }^{9}$ Fala de Wagner, morador, integrante do MULP (Movimento de Urbanização e Legalização do Pantanal) uma das lideranças da região. Nessa ocasião participei junto com a Professora Amélia Damiani de um trabalho de campo no Pantanal pela disciplina Trabalho de Campo em Geografia I em 01/06/2014.
} 
Por fim, a tarefa não menos árdua de organizar o todo para a compreensão dos leitores. Árdua porque organizar não significa necessariamente que a leitura tenha que ser linear. A própria escrita não o foi. Entendo, o que não precisa estar correto, que a apresentação possa funcionar como partes temáticas que compõem a construção como um todo. Separar tais partes me foi o mais difícil, mas o leitor segue pela minha construção de maneira mais segura, o que também não precisa estar correto.

Desse modo, a organização deste trabalho segue uma forma que sugere a própria construção teórica, do geral ao particular, da história como processo categorial que realiza o espaço como possibilidade de análise desse processo, no interior do qual está o lugar como expressão cotidiana das contradições que daí derivam. Portanto, a primeira parte se constitui das categorias gerais da formação capitalista que acredito serem pertinentes para as análises aqui propostas, a produção desigual do espaço, o capital financeiro e a financeirização, as mudanças estruturais na reprodução capitalista, tudo isso como significado para analisar os objetivos aqui propostos. A segunda parte expõe relações particulares desse processo geral na metropolização de São Paulo, pelo viés da produção do espaço como resultado e processo das relações sociais de produção, pois que daí derivam elementos estruturais da análise como são a produção desigual do espaço, a fragmentação da metrópole e as metamorfoses nas relações sociais de produção, o que inclui também a produção do espaço no ambiente fluvial da Bacia de São Paulo. A terceira parte é a realização da produção do espaço no campo de luta cotidiano, o lugar, o Pantanal da Zona Leste como expressão teórica e prática das relações sociais contemporâneas na lógica da reprodução.

Dizem ser a pele o mais profundo, isso me alivia. Tocar o papel, virar as páginas, seguir as linhas, uma após a outra, dessa forma caminhei pelas muitas autoras e autores aqui presentes, pensamentos que me ajudaram a dar esta pequeníssima contribuição, inconclusa por motivos elementares de minhas limitações, ao pensamento sobre o processo social, ele mesmo uma obra inconclusa. 
Parte 1

Elementos Teóricos para a Análise do Espaço 


\section{CAPÍTULO I}

\section{A Produção Desigual do Espaço na Reprodução Capitalista}

As atuais condições da reprodução capitalista se relacionam a diversos momentos que incluem a produção, mas que definem também outras formas, dentre os quais o que denominamos aqui de acumulação de espaço, o qual se apresenta, sobretudo, para investimentos de capital sobreacumulado, processo que se liga mais à crise do que à acumulação, mais à realização de capitais ociosos por um processo de territorialização financeira do que algo oriundo da geração de mais-valia ${ }^{10}$. A acumulação do espaço se faz pela sua realização desigual e pelo resguardo que esse desigual possui enquanto uma "reserva" que serve tanto à territorialização financeira quanto a condição do espaço como fiduciário, contrapartida aos investimentos financeiros. Tais espaços acumulados se resignificam diante das metamorfoses do processo geral de reprodução. Esse raciocínio perpassa não somente a existência de per si do espaço, mas que, diante das múltiplas formas de apropriação que nele incidem combinadas à própria busca por espaço na metrópole, realiza-se primordialmente em áreas densamente ocupadas, expressões de um cotidiano social que inclui formas de uso as mais diversas, dentre as quais a moradia, majoritariamente, de populações empobrecidas. A razão primordial dessa qualidade é a fundamentação jurídica que resguarda a propriedade privada do solo urbano.

Ao se apropriarem destes espaços, acabam também essas populações empobrecidas inseridas no jogo da reprodução por diferentes meios. Relacionam-se o mediato e o imediato, processo que impõe, pela via da reprodução social, o imediato, contingência não somente de se localizar na metrópole, mas do habitar, do jogo de relações que cria e recria as formas de

\footnotetext{
${ }^{10}$ Claro que a realização da mais valia se situa na própria condição de produção do espaço. No trabalho de Flavia Elaine da Silva Martins, a realização da mais-valia no processo de produção do espaço em São Paulo relaciona o mercado financeiro com a produção de edifícios a partir da aquisição de terrenos por incorporadoras na metrópole paulistana, cuja construção, ao lançar mão de mecanismos de superexploração do trabalho, definem patamares da realização da mais-valia tendo a indústria da construção civil como setor produtivo (MARTINS, 2010). Tal processo também foi tratado por Amélia L. Damiani ao pesquisar a indústria da construção em Cubatão-SP, inclusive por localizar formas de exploração do trabalho ligadas às práticas do peonato como garantia de geração de patamares significativos de mais-valia (DAMIANI, 2000).
} 
apropriação, a tessitura socioespacial que define o lugar como expressão do cotidiano. Por outro lado, o mediato é expressão aparente da re-significação, adormecido e latente, designa propósitos sem necessariamente lhes objetivar, aguarda que os imperativos da reprodução the imprimam as determinações jurídicas e políticas da generalização. E esse conflito latente, que por décadas paira sobre os territórios empobrecidos da metrópole, se objetiva diante dos limites impostos à reprodução e ganha significado na territorialização financeira, processo que expõe a expropriação como potencial para a retomada da reprodução na forma de remuneração financeira que passa pela produção do espaço.

É importante e lembrar que não se trata do espaço em si, mas sim do jogo apropriação-expropriação. Este é o que dá fundamento ao espaço na sua atual condição para a reprodução capitalista. Esse movimento é histórico, sempre presente como processo que se define a partir das relações postas primordialmente pela separação trabalho-propriedade, fundamento da expropriação. É possível, nos diferentes momentos do processo capitalista verificar essa potente presença do espaço como elemento significativo dos termos da reprodução. Trata-se da relação que denominamos capital-espaço em certa medida definida pelas relações de produção que se constituem socialmente. São as relações históricas que produzem espaço. São, portanto, relações socioespaciais. Como já dito antes, não o espaço em si, mas este como força produtiva social, como mediação necessária às relações sociais de produção, definido e redefinido por essas mesmas relações. Por outro lado, é também o espaço em si, tornado elemento da reprodução, pois que se realiza como equivalente de capital seja no processo de formação de capital, ou neste que nos interessa mais de perto, a territorialização financeira.

Há uma leitura geográfica de viés territorial, cuja gênese ratzeliana traduz o espaço como poder e soberania, raciocínio difundido e retrabalhado pela lógica do poder por diversos autores importantes, Yves Lacoste e Claude Raffestin são dois exemplos ${ }^{11}$ dentre outros tantos. Na história do Brasil, desde sempre o movimento contraditório capital-espaço se definiu como processo

\footnotetext{
${ }^{11}$ Ver Yves LACOSTE: A Geografia, isso serve em primeiro lugar para fazer a Guerra. Campinas: Papirus, 2005; Claude RAFFESTIN: Por uma Geografia do Poder. São Paulo: Ática, 1993.
} 
elementar, tanto que para alguns autores trata-se de algo "genético", ou mesmo de um "modo de ser"12. Nossa questão aqui, que também envolve poder e soberania, é a do espaço como condição para as nossas reflexões pelo viés da economia política. Na verdade, trata-se do processo contraditório da reprodução capitalista, desde sempre definido a partir das condições negativas postas em movimento pela contradição crise-acumulação. É pensar o espaço no contexto da economia política e chegar à sua produção desigual por este raciocínio, o qual procura se desprender das naturalizações do processo e para revelar a condição do espaço como elementar na produção e reprodução histórica do capital, embora não seja somente isso que o espaço produz e o que se produz nele.

Os termos da reprodução do capital, suas categorias e determinações formais, estão postos historicamente, assim como as contradições internas que os move. Em diferentes momentos da história, tais categorias e determinações se relacionam conforme as condições históricas da reprodução naquele momento, assim como naquele espaço, de tal maneira que um fundamento na análise da modernidade seja a simultaneidade que pressupõe relações socioespaciais desiguais num espaço ao mesmo tempo local e mundial. Daí resulta um movimento desigual no tempo e no espaço, o qual dispõe formas de uma economia geral desigualmente posta no espaço mundial, a qual cria e recria os lugares, as regiões enquanto racionalidade pressuposta pela modernização que se generaliza, torna-se ao mesmo tempo um processo civilizatório e um devir, que será correspondido pela forma desigual como esta se incorpora, ou melhor, impõe-se ao produzir relações sociais e, portanto, espaços. Dessa forma, o movimento histórico de reprodução do capital põe e opõe as categorias imanentes dessa reprodução. "Na vida prática, encontra-se não apenas a concorrência, o monopólio e o seu antagonismo, mas também a síntese, que não é uma fórmula, e sim um movimento" (MARX, 1985 p.141). No momento histórico atual, tais categorias se relacionam em condições outras

12 Antonio C. R. MORAES (1994) vai definir a conquista territorial como genética em nossa história, assim como Wanderlei M. da COSTA (1988) define este processo como um modo de ser histórico com relação ao território. (ver respectivamente Meio Ambiente e Ciências Humanas. São Paulo: Edusp, 1994; Estado e Políticas Territoriais no Brasil. São Paulo: Contexto, 1988). 
que nos momentos anteriores, mas é de sua relação contraditória que pensamos as condições atuais de sua reprodução.

A reprodução do capital não se apresenta somente enquanto acumulação, mas simultaneamente como crise, contradição imanente que move o processo. A contradição entre as forças produtivas e as relações de produção torna-se limite e processo ao mesmo tempo. No movimento posto pela contradição, uma e outra são positividade e negação, visto que, quanto mais se desenvolve a produção capitalista, mais crítica se torna a sua reprodução. Em diferentes momentos da história é possível revelar a forma antitética do capitalismo e de que maneira as relações sociais se estruturam por processos que parecem excludentes um ao outro, mas são na verdade uma simultaneidade posta pelas próprias condições de reprodução. Simultaneamente, o processo industrial em diferentes regiões da Europa e a instituição da escravidão na América compunham as condições históricas da reprodução do capital no século XVIII. "A escravidão, por ser uma categoria econômica, sempre existiu nas instituições dos povos. Os povos modernos conseguiram apenas disfarçar a escravidão em seus próprios países, impondoa sem véus no novo mundo" (idem, p.108). O que está posto e se define na categorização primordial é a relação trabalho-capital, cujas variações se realizam nas condições desiguais de reprodução nos termos de uma economia mundial que, simultaneamente, inclui diferentes relações sociais de produção.

Dessa forma, a condição da realização do capital a partir da existência de espaços desiguais no processo de reprodução contemporâneo perpassa antigas e sempre presentes práticas de expropriação. $\mathrm{Na}$ "chamada acumulação primitiva", Marx (1980, livro I, cap. XXIV) nos expõe o primordial da reprodução, a separação entre trabalhador e meios de produção, a transformação dos meios de subsistência em capital: "[...] é apenas o processo histórico que dissocia o trabalhador dos meios de produção [...] a expropriação do produtor rural, do camponês, que fica assim privado de suas terras, constitui a base de todo o processo" (idem, p. 830, 831). Por um lado, as instituições como o Estado definem a relação propriedade-expropriação pelo poder, pela violência, pelas instituições jurídicas de sua constituição política, como esta que institui a propriedade privada capitalista, momento que relaciona a classe dos proprietários capitalistas ao desenvolvimento do próprio Estado. 
Como o próprio Marx nos revela, a composição orgânica do capital é definida neste processo de separação conduzido pela relação entre classes dominantes e Estado e que resulta nas categorias essenciais da formação capitalista, ao constituir a força de trabalho rural e urbana como capital variável e os elementos materiais aqui produzidos agora como capital constante (idem p. 863). Mas, mais do que isso, e primordial para as considerações sobre o processo histórico contemporâneo, o Estado participa na definição da substância das relações sociais de produção, ou seja, que a produção econômica moderna não é somente um cálculo, mas um processo histórico que fundamenta, constitui e reproduz as relações sociais como relações de produção, a "nova alma" que entra no corpo das coisas:

\begin{abstract}
Imaginemos uma parte dos camponeses de Westfalia que, no tempo de Frederico II, fiavam todo o linho que produziam, fosse violentamente expropriada e expulsa de suas terras, sendo os restantes que lá ficassem transformados em jornaleiros de grandes arrendatários. Suponhamos ainda que se construam grandes fiações e tecelagens onde esses expropriados possam trabalhar como assalariados. O linho não mudou materialmente em nada. Não se modificou nenhuma de suas fibras, mas uma nova alma social entrou no seu corpo (lbidem).
\end{abstract}

Por se tratar de formas de expropriação seria então, como nos diz Amélia Damiani, uma "acumulação primitiva sempre renovada"? (DAMIANI, 2000 p. 28). Sim, em certa medida. No entanto, condições outras nos fazem repensar alguns termos deste processo. Tratemos esta realização a partir do que pode ser um primeiro momento desta análise, uma acumulação primitiva que se realiza no e pelo espaço. Para tanto, cabe considerar que a acumulação primitiva em si é um processo presente no próprio movimento de reprodução do capital que se constitui historicamente por formas de expropriação no sentido de acumular elementos necessários e definidores da reprodução naquele momento, inclui-se o espaço, combinados às condições simultâneas em que o capital se realiza. Para Francisco de Oliveira:

[...] a acumulação primitiva não se dá apenas na gênese do capitalismo: em certas condições específicas, principalmente quando esse capitalismo cresce por elaboração de periferias, a acumulação primitiva é estrutural e não apenas genética (OLIVEIRA, 2003 [1972] p. 43).

Importante chamar a atenção para as outras possibilidades presentes a partir desse pensamento da produção desigual, que é a formação de espaços 
periféricos, que incorporam e reproduzem territorialmente elementos exteriores, como pressuposto da formação de espaços centrais, de onde se impõem e se expandem as demandas da reprodução, não necessariamente nessa ordem, menos ainda separadamente, mas que ambas as categorias se definem numa relação. Determinados espaços se constituem como centros do sistema e operam as definições políticas e de poder, assim como definem as relações socioespaciais nesses espaços periféricos conforme as condições da reprodução, o que também possibilita, no interior da relação, que a própria periferia, a partir das relações contraditórias capital-espaço, possa tornar-se centralidade. A relação que se estabelece marca uma construção também definida pelas condições da divisão territorial do trabalho, uma vez que possibilita a formação de capital e sua reprodução na outra ponta, pois configura estruturas que integram trabalho morto e trabalho vivo, improdutivo e produtivo e dessa forma compõem o processo geral da reprodução. Esse processo se desenvolve pelas premissas da existência desigual de espaços, pelas formas de expropriação que nestes atuam, postas pela separação primordial trabalho-propriedade. Vejamos alguns argumentos dessa construção.

Francisco de Oliveira relaciona a reprodução capitalista que ocorre no Brasil na década de 1970 a partir da integração dos setores urbano e rural, "moderno" e "arcaico", na qual a expansão territorial, a incorporação de novos espaços serve ao modelo de expansão capitalista, mas não como dualidade e sim numa relação dialética, cujo processo territorial, ou seja, de expandir os mecanismos de dominação e as formas de poder da burguesia dominante, posto em ação pelo Estado, torna-se definidor neste movimento:

A solução do chamado problema agrário nos anos de passagem da economia agrário-exportadora para urbanoindustrial é um ponto fundamental para a reprodução das condições de expansão capitalista. É um complexo de soluções, cujas vertentes se apoiam no enorme contingente de mão de obra, na oferta elástica de terras e na viabilização do encontro desses dois fatores pela ação do Estado construindo a infraestrutura, principalmente a rede rodoviária. Ela é um complexo de soluções cujo denominador comum reside na permanente expansão horizontal da ocupação com baixíssimos índices da capitalização ou sem nenhuma capitalização prévia: numa palavra, opera com uma sorte de "acumulação primitiva" (Ibidem). 
Por meio desses mecanismos de expansão territorial acompanhados de formas de expropriação, o Estado e suas ferramentas, sobretudo o planejamento, opera a incorporação desses espaços, digamos, pouco ou quase nada capitalizados, de certa maneira, "resguardados" de uma integração mais efetiva (pois que não existem espaços não capitalistas), ao mecanismo de reprodução ampliada. Mais adiante, os processos distintos em sua aparência, rural e urbano, se relacionam internamente pela penetração de formas mais absolutas das relações sociais de produção pressupostas pelas categorias primordiais do capitalismo, a partir das quais rural e urbano se explicam no interior da relação contraditória, e não mais separadamente.

À expansão territorial corresponde à expropriação, a qual ocorre, segundo o autor, no excedente e não na terra, mas permite o processo de acumulação na outra ponta, no setor urbano industrial ao definir, pela expropriação do excedente, a formação de preços agrícolas compatíveis com a reprodução da força de trabalho urbana, numa combinação que permite manter o que o autor definiu por agricultura "primitiva" combinada às formas de modernização, que reproduz aquela no interior do sistema, e não como algo externo que suponha um argumento dualista, mas que resulta de uma relação intrínseca:

[...] ao impedir que crescessem os custos da produção agrícola em relação à industrial, ele (o modelo de combinação "atrasado" x "moderno") tem um importante papel no custo da reprodução da força de trabalho urbana; e, em segundo lugar, e pela mesma razão de rebaixamento do custo real da alimentação, ele possibilitou a formação de um proletariado rural que serve às culturas comerciais de mercado interno $\mathrm{e}$ externo (Idem, p. 45).

É importante ressaltar nesse momento que, mesmo que a expropriação não se dê na terra em si, o elemento estrutural da separação posta pelas relações trabalho-capital revela a expropriação como trabalho excedente. Este autor define a acumulação primitiva interna e integrada à reprodução do capital, como elemento estrutural posto por relações aparentemente diferenciadas entre o "moderno" e o "arcaico". "Longe de um crescente e acumulativo isolamento, há relações estruturais entre os dois setores que estão na lógica do tipo de expansão capitalista [...] por detrás dessa aparente dualidade existe uma integração dialética" (Idem, p. 47-8). 
Numa linha de pensamento semelhante, Jose de Souza Martins (1997) ao tratar mais recentemente da expansão territorial brasileira em direção à Amazônia, situa uma combinação entre o que é capitalista e o que é précapitalista, diferenciados no interior do processo por seus conteúdos categoriais. Para este autor, embora definida como histórica e recorrente no processo do capital, a acumulação primitiva estaria envolvida numa trama temporal e, em certos momentos, confundida com o processo de acumulação em si, deste distinguida:

Quando se pensa em acumulação primitiva como processo [...] pode-se entender que é processo que pode ter, e tem, ritmo mais ou menos lento. Por isso, além de ser um requisito histórico da acumulação capitalista (e não necessariamente um requisito simultâneo dessa acumulação em todos os ramos e momentos da produção), a acumulação primitiva pode mesclar e se confundir com a reprodução do capital (Idem, p.96).

Por tais condições, Jose de Souza Martins inclui momentos históricos, e porque não dizer também espaços, capitalistas e não-capitalistas como integrados pelas relações de produção, pela divisão territorial (grifo nosso) do trabalho: "produção de capital no interior do processo de reprodução ampliada do capital, [...] reprodução de capital com base em relações formalmente capitalistas de produção" (ibidem). Embora pareçam processos separados, ocorrem de maneira simultânea no movimento geral da reprodução ampliada, mas que não podem ser confundidos, produção de capital e reprodução ampliada, são distintos, pois:

[...] não se pode falar em produção capitalista de capital, pois a produção de capital envolve mecanismos e procedimentos próprios da acumulação primitiva. Envolve, portanto, a conversão de meios e situações não-capitalistas ou précapitalistas em instrumentos de produção capitalista propriamente dita (Ibidem).

Para ambos os autores, as condições de expropriação, de acumulação primitiva (nestes casos, expropriação do excedente), se situam na diferenciação interna, na combinação de espaços desiguais que revelam formas distintas em relação à reprodução ampliada, mas que operam no interior desta. Conforme Jose de Souza Martins, por uma modernização conservadora, e para Francisco de Oliveira, uma combinação desigual. 0 primordial dessa construção é a constatação de que o fundamento da relação 
capital-espaço se situa na diferenciação interna deste próprio espaço e em formas de expropriação consubstanciadas nestas e por estas diferenciações internas. Formação de capital e reprodução ampliada estão distintas e integradas pela lógica da desigualdade espacial.

Francisco de Oliveira, em outra obra que trata da inserção da "Região"13 Nordeste numa economia mundializada a partir da segunda metade do século $X X$, expõe de que maneira essa região "atrasada" se insere nas condições de reprodução dadas pelo centro dinâmico urbano-industrial representado pelo Centro-Sul conforme uma "combinação desigual". Segundo o autor, o "atrasado" e o "moderno" se realizam a partir das contradições internas entre as forças produtivas e as relações de produção e que tais dinâmicas definem diferenciações propícias às novas condições de reprodução ao possibilitar que "regiões" situadas nesse descompasso possam permitir formas de reprodução a partir de sua inserção na divisão "regional" do trabalho.

[...] precisamente no descompasso entre o nível das forças produtivas ou formas de reprodução do capital e relações de produção é que reside uma das contradições básicas do sistema capitalista de produção, e exatamente essa perspectiva é que abre possibilidades mais ricas para o estudo concreto dessa combinação desigual (OLIVEIRA, 2008 [1977] p. 148).

Nessa construção, o autor trabalha as contradições postas pelo descompasso na relação entre forças produtivas e relações de produção como estruturais na constituição de espaços diferenciados cuja aparência reflete a existência dual entre o moderno e o arcaico, arcabouço das formulações teóricas baseadas nos "desequilíbrios regionais", para os quais, as formas de integração a partir de políticas de desenvolvimento seriam a solução. Deste raciocínio, cujo aparente desequilíbrio não é mais do que uma integração dialética dessas diferenciações espaciais, emerge o Estado e a forma do planejamento, segundo o autor, "uma forma técnica da divisão do trabalho":

O Planejamento emerge aqui como uma "forma" de intervenção do Estado sobre as condições entre a reprodução do capital em escala nacional e regional, e que tomam a aparência de conflitos inter-regionais; o planejamento não é portanto a presença de um Estado mediador, mas, ao contrário, a

${ }^{13}$ As aspas no termo região são do autor por definir que a tendência de homogeneização do capital põe termo à estas diferentes áreas. Como exemplo, cita os Estados Unidos, cuja homogeneidade na produção capitalista, embora aconteça em áreas diferentes, criou um conjunto homogêneo e suprimiu aquilo que para o autor se define por regiões. 
presença de um Estado capturado ou não pelas formas mais adiantadas do capital para forçar a passagem no rumo de uma homogeneização ou, conforme é comumente descrito pela literatura sobre planejamento regional, no rumo da "integração nacional". Nem ainda o planejamento é uma forma neutra dessa presença; ao contrario, ele é, no mais das vezes uma forma transformada pela própria luta de classes, tanto ao nível das contradições entre as formas diferenciadas, "regionais", daquela reprodução e as mesmas formas das relações de produção (Idem, p.149).

Esses princípios norteiam uma construção teórica a partir da lógica da reprodução desigual do espaço, cujos elementos estruturais desta podem integrar a formação de capital e/ou a reprodução ampliada. De qualquer maneira, o processo é um só, a reprodução capitalista baseada na lógica dos espaços desiguais, como inserção destes no processo de divisão do trabalho, cuja realização se faz pela intervenção do Estado, sobretudo na forma do planejamento, como foi a história do Brasil, principalmente a partir da segunda metade do século XX, momento em que se busca integrar aquilo que os ideólogos da integração nacional denominaram de "vazios demográficos", justamente porque neles, pelo ponto de vista das formas técnicas, as populações são invisíveis, e só se tornam, ou mesmo surgem como "cidadãs" ao fazerem parte da expansão das fronteiras da modernização. Claro, não poderíamos deixar de mencionar o genocídio que tal processo perpetua nas fronteiras da modernização, o qual implica no extermínio de populações tradicionais (chamemos assim), ribeirinhos, caboclos, indígenas, caiçaras, quilombolas, enfim, um avassalador processo que parece remeter aos recônditos do colonialismo, mas que aqui estão, sempre estiveram, na formação do Brasil, o que, de per si, já significa em todos os tempos, o moderno.

Embora a expansão territorial seja um processo dominante na condução da política brasileira desde os primórdios da colonização, precisamos tratá-la de um ponto de vista da economia política, para a qual a existência de espaços desiguais resulta em formas de apropriação-expropriação que dão conteúdo às condições da reprodução nos termos da modernidade em todos os seus momentos. A produção desigual então define o que é moderno e que não é. $O$ Estado, pela via do planejamento define a maneira como tais espaços serão integrados ao moderno. As ideologias impõem a necessidade dessa integração 
e lhe dão sentido. E o privado se apropria do espaço como elemento da reprodução capitalista. Portanto, a expropriação integra um processo mais amplo e ao mesmo tempo particular, ao qual nos referimos por uma situação geográfica, momento em que os elementos constitutivos do espaço tornam-se potenciais para a definição da expropriação como condição da reprodução capitalista.

Podemos aproximar a escala de análise e verificar estas relações na São Paulo no início do século $X X$, nos primórdios da metrópole, quando o duplo industrialização-urbanização se sedimentava pelas condições de formação de uma classe dominante relacionada a uma economia mundial, processo que requeria e ao mesmo tempo definia determinadas condições sociais propícias a este novo momento da reprodução capitalista no Brasil, e cuja centralidade era São Paulo, ou, como definiu Francisco de Oliveira, o urbano-industrial era o centro do sistema (OLIVEIRA, 2003 [1972] op. Cit.). Mecanismos de formação de capital aliavam-se à produção de mais-valia, ao expropriarem tanto o trabalho como a terra.

Para o caso de São Paulo, que envolve a produção do espaço a partir da apropriação privada dos ambientes fluviais, um exemplo significativo é o da Cia. Light And Power S/A, empresa multinacional que foi o centro da pesquisa da Professora Odette Seabra ${ }^{14}$. A autora pôde desvendar a relação entre a reprodução de capital desta empresa relacionada ao seu espaço de atuação tanto empresarial quanto político. Essa parcela do espaço metropolitano correspondente às várzeas do rio Pinheiros, espaço no qual a empresa dirigiu os mecanismos políticos e econômicos de expropriação de populações da respectiva área de interesse, ao mesmo tempo em que este mecanismo propiciava-Ihe uma formação de capital baseada na apropriação privada de terras como equivalente de capital. No entanto, uma novidade se situava nesse processo: as formas de apropriação privada do ambiente fluvial das várzeas como resultantes de formas de expropriação. Conteúdos de novas condições da técnica e da engenharia, assim como novas necessidades relacionadas à urbanização-industrialização de São Paulo geraram as condições para esta

${ }^{14}$ SEABRA, 1987 op. Cit. 
realização, e tiveram no Estado a forma política necessária para o processo como um todo.

Resumidamente, a Cia. Light, para a construção de um sistema de geração de energia hidrelétrica em São Paulo, mais precisamente na Bacia do Alto Tietê, definiu os parâmetros territoriais desse sistema a partir da apropriação privada dos ambientes fluviais que the correspondiam na cidade de São Paulo, aqueles do rio Pinheiros, o qual deveria ter seu curso revertido para que fosse possível a geração de energia elétrica diante das condições naturais aqui dispostas. Havia, portanto, uma dupla correspondência, ideológica e prática, pois nos moldes do higienismo era necessário sanear as várzeas. Por outro lado, nos moldes do progresso, era necessário gerar energia.

Se apresenta para a Light a forma urbana do espaço produzido para o progresso e para o saneamento como possibilidade para um processo de formação de capital a partir das formas de expropriação consubstanciadas à apropriação privada das terras no entorno do referido rio.

O desigual é justamente aquilo que a Light produziu, um aparato do progresso como significado da modernização em meio a um urbano ainda muito ruralizado, "atrasado", caipira, impróprio aos elementos da modernização propugnados naquele momento.

Os negócios com a terra, as possibilidades desta como equivalente de capital, como forma mercadoria, e principalmente, que na modernidade a separação posta pela relação trabalho-propriedade privada relaciona a terra ao trabalho como representação equivalente, foram estes os mecanismos que sustentaram o processo de valorização naquele espaço e foram representados pelo preço da terra a partir do trabalho objetivado nas várzeas como componente da urbanização em São Paulo.

Veja-se o exemplo do Clube Pinheiros, o qual moveu um processo na justiça pelo direito à propriedade e ao uso dos rios e várzeas em função dos esportes náuticos praticados ali. A resposta a este processo foi:

"O Esporte Clube Pinheiros se obriga a pagar à The São Paulo Tramway Light and Power Company, Limited, a quantia de $\mathrm{Cr} \$$ 200.000,00 (duzentos mil cruzeiros) essa importância corresponde ao saldo de débito pelo benefício introduzido em sua propriedade na várzea do rio Pinheiros, em virtude das obras realizadas por esta Companhia" (SEABRA, 1987 p. 207). 
Se explicavam também numa lógica mundial, pois tratava-se de acréscimo monetário em função do movimento financeiro do dinheiro como meio de circulação, meio de consumo.

Há outro relato de um morador expropriado, obrigado a deixar sua propriedade pois que esta foi definida no perímetro requisitado pela Light para as obras, o qual requer, por meio da compra, tornar a ser proprietário daquela porção da superfície terrestre. Responde-Ihe a Light:

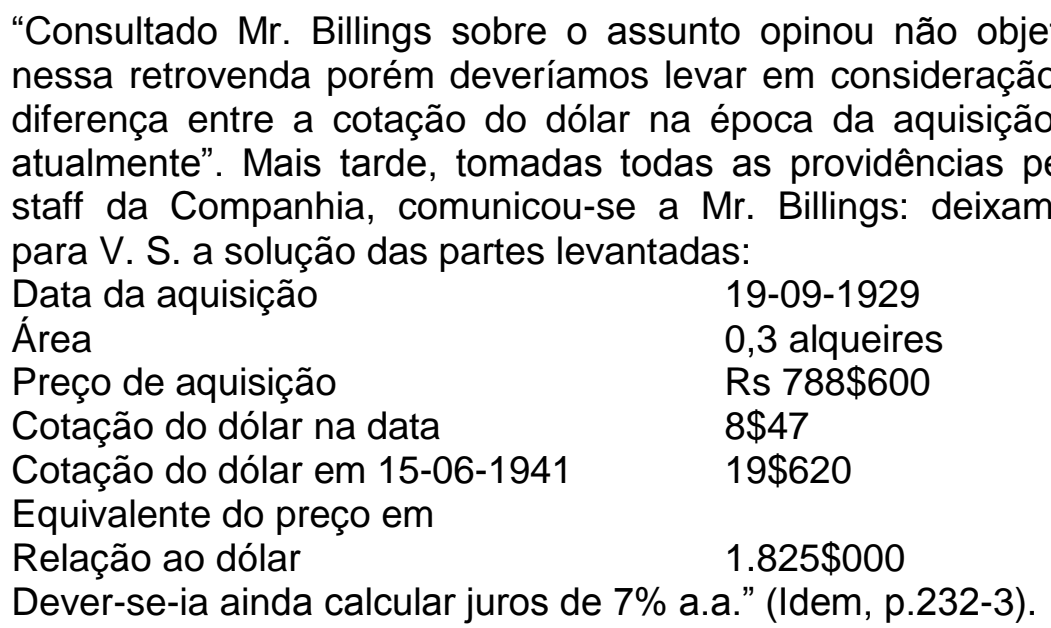

Ou seja, o preço da terra naquela operação ganhou outra dimensão muito mais vantajosa e da qual a Light se valeu no campo dos negócios imobiliários pois que a retirada dos moradores e instituições e a apropriação privada das terras requeridas ao Estado possibilitaram um considerável processo de formação de capital. Claro que, após isso, se sedimenta também o trabalho como equivalente social, o qual se representa no preço da terra, mas que se definiu primordialmente na relação capital-espaço dada pelas formas de expropriação que o Estado referenciou legalmente e que a Light conduziu de maneira que o seu aparato técnico e de engenharia possibilitaram tal situação, fato que consagrou tais terras tornarem-se propriedade privada da Light. Mais do que isso, tal estudo mostra a terra como um equivalente de capital inserida numa lógica social e histórica, própria dos elementos da modernização e também das categorias elementares do capital, terra-trabalho-renda.

Este é um apanhado muito resumido da referida pesquisa, da qual tornaremos a falar outras tantas vezes, dada a sua importância. Essa construção teórica nos auxilia no pensamento específico sobre a área de estudo, o Pantanal da Zona Leste de São Paulo, cuja transposição se define 
para as condições do espaço metropolitano na sua contemporaneidade. As formas de expropriação dos moradores das várzeas do Tietê no Pantanal da Zona Leste se assemelham àquelas produzidas nas décadas iniciais do século XX pela Light, por esta empresa deter as condições técnicas de operação do sistema hidrográfico da Bacia do Alto Tietê que, combinado às condições meteorológicas particulares do ano de 1929, possibilitaram a inundação de significativas áreas ao longo da planície fluvial do rio Pinheiros e dessa forma tornaram a Light proprietária justamente pela expropriação dos moradores. $O$ que importa é pensar nas condições do espaço como elemento estrutural da reprodução capitalista e que, para esses casos particulares, o ambiente fluvial das várzeas se torna potência na operação de "desapropriação", tanto naquele momento como agora, quase cem anos depois. No entanto, se explicam de maneiras diferentes, por práticas e também por construções ideológicas no campo das contradições contemporâneas.

Diante disso, ocorrem outros processos os quais revelam o espaço como fragmentado, posto pelas relações de produção que diferenciam estruturalmente tais fragmentos não como parcelas arcaicas e modernas, atrasadas e contemporâneas, centros e periferias, mas como condição intrínseca oriunda de complexos e simultâneos processos de ressignificação, os quais se apresentam para a reprodução na forma atual das relações capitalespaço, na qual o Estado e sua forma política do planejamento hão de realizar.

O desigual se apresenta na atualidade na forma de fragmentos, resultado de uma metropolização que se definiu ao longo de sua constituição como um processo de implosão-explosão ${ }^{15}$. Corroído por dentro, o espaço metropolitano revela em todo o seu conjunto o dilaceramento de um processo posto pela hierarquização socioespacial, na qual os lugares se re-significam a partir de objetivações, de estruturas que Ihes qualificam ao processo geral da reprodução, mas que é também coisificação, os objetos e seus signos tornados símbolos tanto da modernização como seu distanciamento ${ }^{16}$; a forma

\footnotetext{
${ }^{15}$ Ver LEFEBVRE, 1999; 2001, op. Cit.

${ }^{16}$ O Estádio do Corinthians, o Itaquerão no bairro de Itaquera na Zona Leste, é um bom exemplo de como tais signos simbolizam a proximidade ou não à modernização, pela centralidade que este objeto passa a significar no contexto não somente metropolitano, mas mundial, dada sua condição de sede da Copa do Mundo de Futebol 2014. Itaquera se cindiu em Itaquerão, aquilo que o aproxima do moderno e ao mesmo tempo permaneceu Itaquera como fragmento precário na metrópole.
} 
mercadoria e o fatiamento irrestrito do solo em lotes, o rentismo em todas as esferas sociais, a não-propriedade ela mesma enquanto forma mercadoria que molda o imediato, a contingência da moradia. Tudo isso se espraia num conjunto extenso que se apresenta estilhaçado pela presença não mais restrita e sim ampliada de todos os fragmentos em todos os lugares, posto que o espaço mercadoria pode, aqui ou acolá, redefinir os patamares da reprodução. Tornado possível-impossível, o espaço da metrópole une separadamente tudo que the anima e the estanca, que lhe compõe e decompõe. Vista de cima, distante, por imagens de satélite, a metrópole é um conjunto multicolorido numa forma areolar homogênea. Ao nos aproximarmos vemos que a textura desigual é o que forma esse todo, os retalhos de uma costura cuja linha nos é invisível, mas ao mesmo tempo real, pois que os fragmentos não se dissociam, costurados pelas agulhas que as relações sociais de produção põem a mover.

E é neste contexto de fragmento que podemos pensar a área de estudo, o fragmento desigual de tudo aquilo que também é desigual e que por isso se torna potência na realização das formas contemporâneas da relação capitalespaço. Mas atingi-la pelo pensamento significa contextualiza-la na produção desigual do espaço e sua construção teórica enquanto economia política do espaço. Falta um detalhe, justamente o do ambiente fluvial das várzeas no jogo contemporâneo das formas de expropriação como necessidade para as novas formas de reprodução, uma vez que se metamorfoseiam as próprias condições intrínsecas da realização do capital. Nesse jogo de novidades, para o caso da área pesquisada, o ideário, as formas veladas que impulsionam as expropriações são o ambientalismo e o risco social. Novas formas para que conteúdos historicamente constituídos se objetivem, obscurecidos pelos mecanismos ideológicos sempre presentes no jogo das representações do espaço, cuja realização possibilita a estes mesmos mecanismos tornarem-se espaços de representação, mas que, no interior de tudo, nos interessa localizar como se realiza a reprodução nessa lógica ideológica. 


\section{Capítulo II}

\section{O Movimento Crise-Acumulação e o Processo de Financeirização}

Internamente, o processo do capital é negativo. Seu movimento se constitui por essa negatividade, uma contradição imanente que impele o capital a se expandir como necessidade de acumulação, ao mesmo tempo em que essa mesma acumulação se torna crítica. Simultaneamente, operam diversos formatos da produção baseados em composições orgânicas muito diferentes, assim como as formas do próprio capital, financeiro, industrial, comercial, se apresentam por montantes variados. Esse processo é desigual no tempo e no espaço, mas esse desigual passa por uma combinação na qual se estruturam mudanças na forma predominante. Passamos atualmente por um momento de clara predominância financeira na forma do capital, o que não exclui as outras, pelo contrário, as inclui numa totalidade operante de maneira que o capital possa se reproduzir acrescentando-se a si mesmo. Noutros tempos, com mais clareza, esse acréscimo se definia pela substância imanente de todo o processo, o valor. Parece que os tempos são outros e os arranjos na combinação desigual passam a significar um aprofundamento das relações negativas expostas por uma massa incomensurável de capital financeiro, muito dele disposto de forma fictícia. Uma pequena compreensão deste processo se faz necessária para relacionar capital e espaço na reprodução contemporânea.

A atual predominância da esfera financeira na centralização do capital e, portanto, das decisões políticas e de poder, se constituiu historicamente como necessidade da própria reprodução capitalista. A obra de Lênin, editada pela primeira vez em 1917, discorre sobre a tendência monopolista do capital já em fins do século XIX baseada em "fusões" e aquisições de grupos econômicos mobilizando grandes massas de capital oriundo da união "íntima" (aspas minhas) entre o capital bancário e o capital industrial, a qual resulta:

[...] acentuada dependência da grande indústria face a um pequeno número de grupos bancários. A estreita ligação entre 0 industrial e o mundo das finanças restringe a liberdade de movimento das sociedades industriais que têm necessidades de capitais bancários [...] no que diz respeito à íntima ligação existente entre o banco e a indústria [...] o banco não abandona o seu modesto papel de intermediário [...] porem [...] se o 
banco tem em mãos enormes capitais de uma empresa [...] daí resulta uma dependência cada vez mais completa [...] A união pessoal de bancos e das indústrias é completada pela união pessoal de uns e outros com o governo (LENIN, 1979 p. 41).

O autor demonstra que tal predominância se consubstancia como processo histórico (embora este prefira falar em fase):

O capitalismo chega à sua fase imperialista, conduz à beira da socialização integral da produção; ele arrasta o capitalista, seja como for, independentemente de sua vontade e sem que ele tenha consciência disso, para uma nova ordem social, intermédia entre a livre concorrência e a socialização integral (Idem, p. 23).

A tendência monopolista apontada pelo autor se define no plano da concorrência entre os capitais como devir que realiza não a concorrência, mas o monopólio, no qual predomina substancialmente o capital financeiro: "a supremacia do capital financeiro sobre todas as outras formas do capital" (Idem, p.58), pois:

[...] o que é próprio do capitalismo é separar a propriedade do capital de sua utilização na produção; separar o capital-dinheiro do capital industrial ou produtivo; separar aquele que vive apenas dos rendimentos obtidos do capital dinheiro, não só do industrial, como de todos aqueles que participam diretamente na gestão dos capitais. O imperialismo, ou o domínio do capital financeiro, é aquela fase superior do capitalismo na qual esta separação atinge vastas proporções (Ibidem).

O conteúdo desse processo revela-se também na relação capital-espaço a partir de diferentes mecanismos postos pelo imperialismo que resultam em grandes massas de capital em geral movendo-se num espaço mundial, na forma de indústrias multinacionais, monoculturas, extração de recursos, alavancados por forças produtivas relacionadas à expansão do capital na sua forma financeira, ou seja, que a combinação desigual da reprodução capitalista é a própria produção desigual do espaço.

Por mais de três décadas a partir de meados do século $\mathrm{XX}^{17}$ o processo de acumulação centrado na produção de mais-valia se manteve em níveis satisfatórios. Baseado na expansão territorial do processo industrial pela via

\footnotetext{
${ }^{17}$ A expansão da produção para por todas as regiões do planeta, um grande desenvolvimento tecnológico acompanhados de registros de crescimento econômico e melhoria das condições de vida dos trabalhadores dos países centrais foi cunhado por alguns autores de "Idade de Ouro". Ver Eric HOBSBAWN: A Era dos Extremos. São Paulo: Cia. Das Letras, 2005, pp. 1126.
} 
das empresas multinacionais, as quais se instalaram em grandes regiões do chamado mundo subdesenvolvido, o processo de acumulação produziu efetivos de força de trabalho em escala mundial que garantiram massa de valor suficiente para sustentar os níveis globais da acumulação. Na verdade, se apresenta, como em todo o processo histórico do capitalismo, a simultaneidade, uma vez que nas grandes concentrações industriais dos países ditos centrais, a concorrência, a tecnologia, a gestão empresarial, enfim, acabaram por redefinir os patamares das taxas de lucro nestes países, nos quais tais taxas apresentavam uma queda tendencial ${ }^{18}$. De certa maneira, tal processo impele a produção capitalista na busca de novas áreas, na tentativa de compensar as taxas de lucro das áreas centrais e remunerar seus capitais, condições sempre redefinidas pela concorrência entre os capitais. A relação entre o espaço e o capital proporciona que a expansão territorial da exploração da força de trabalho na forma de mais-valia absoluta possa manter ou ampliar os níveis de acumulação. David Harvey se apropria da leitura de Rosa Luxemburgo, a qual relaciona capital e espaço por meio das formas imperialistas e colonialistas de expansão da acumulação, sobretudo em meio às dificuldades de realização da mais-valia:

Uma forma potencial de sair dessa dificuldade é ampliar as relações comerciais com sociedades e setores não capitalistas ou pré-capitalistas. Esta seria a solução de (Rosa) Luxemburgo ao problema da demanda efetiva, e a levou a estabelecer uma firme conexão entre a acumulação de capital e a expansão geográfica do capitalismo por meio de políticas coloniais e imperialistas. (HARVEY, 1990 [1982] p. 102-3).

Acontece que há uma contradição imanente entre a expansão da exploração do trabalho na forma da mais-valia absoluta em relação à maisvalia relativa, esta que estabelece a exploração relativamente às formas de organização do trabalho e de sua conjunção à maquinaria. É uma das relações críticas do capitalismo e o põe em movimento através do espaço na busca de integrar grupos sociais ao processo de exploração do trabalho assim como

\footnotetext{
${ }^{18}$ Karl Marx analisou esse processo que se encontra no Livro Terceiro, Seção III d'O Capital (op. Cit.). Sobre o assunto da queda tendencial e da consequente financeirização ver: O Futuro do Trabalho: Elementos para a Discussão das Taxas de Mais-Valia e Lucro. São Paulo: AGB/SP, LABUR/Programa de Pós-Graduação em Geografia Humana, Departamento de Geografia, FFLCH/USP, 2006. Livreto produzido pelo grupo de estudos coordenado pela Profa. Amélia Luísa Damiani do Laboratório de Geografia Urbana - Departamento de GeografiaUniversidade de São Paulo.
} 
apropriar-se privadamente das forças produtivas destes novos espaços. O fundamento dessa expansão permanece o primordial da relação histórica, a separação entre a propriedade e o trabalho. A expropriação está no centro desse movimento e produz simultaneamente o avanço e o atraso, processos sempre renovados, já presentes nos primórdios da formação capitalista, descritos na mais pura violência que permeia o movimento do capital como um todo.

A desigualdade socioespacial, ou seja, contingentes populacionais empobrecidos, espaços potenciais para exploração capitalista, tornam-se nessa lógica, fundamentos da acumulação, ao mesmo tempo em que esta se defronta à crise, movimento próprio da concorrência capitalista. Dessa forma, a expansão das fronteiras da exploração, fundamentadas na apropriação privada da terra e do trabalho tornam-se primordiais para a permanência da remuneração dos capitais, ainda que este processo implique conectar, a partir da divisão do trabalho, áreas em hemisférios diferentes, como foi o caso da incorporação no século $\mathrm{XX}$ de vastos espaços da América Latina ao processo de expansão capitalista ditado pelos centros de poder, Estados Unidos e Europa Ocidental ${ }^{19}$ fundamentalmente.

As condições para a reprodução do capital se definem não somente na concorrência entre os capitais, mas também, e principalmente, pela condição política e de poder em que se apresenta o Estado como agente da produção econômica, portanto, também agente da produção do espaço. A partir de sua forma, o Poder Político, assume papel significativo de maneira a dinamizar o processo de reprodução ao proporcionar, por um lado, adiantamentos de grandes massas de capital, e de outro, a condição de legislar e produzir o espaço, a infraestrutura primordial, além da própria condição coercitiva de exercer o monopólio da violência em favor deste processo posto pela dupla condição de dispor do poder jurídico e também policial.

Manter a remuneração dos capitais investidos nesse processo não se trata, porém, de algo puramente econômico. As formas de apropriação privada da riqueza produzida socialmente trazem consigo uma condição política, pois

${ }^{19}$ Digo Europa Ocidental não somente pelo momento da Guerra Fria no pós anos 50 do século $\mathrm{XX}$, a separação em "duas Europas", mas que os grandes centros políticos da economia capitalista situam-se nesta porção territorial do continente, Inglaterra, França e Alemanha principalmente. 
que se encaminham pela via da expropriação, ora disfarçada por processos políticos como tem sido o planejamento territorial, ora pela pura forma da violência, monopólio de fato do Estado. Em muitos casos, como o do Brasil, pela junção de ambas, pelo monopólio de fato e de direito do Estado, o poder de legislar sobre o território e o poder da violência. No Brasil, o Estado torna-se a principal via que permite a manutenção da apropriação privada da riqueza social e, por mecanismos fiscais, de remessas de lucro, entre outras formas econômicas, garante a remuneração dos capitais do outro lado do Atlântico, ou mesmo alguns milhares de quilômetros ao norte, em direção aos Estados Unidos, o que foi mais comum para o nosso caso.

Nesse contexto, o processo se fundamenta nos moldes políticos, estes que possibilitaram manter as taxas de acumulação que garantiram remessas de lucro e remuneravam os capitais monopolistas de grandes empresas multinacionais, estadunidenses em sua maioria. Vale ressaltar que o Brasil, e toda a América Latina, passam por um período ditatorial de décadas e dezenas de milhares de mortos, além da repressão social que o poder militar destes países impunha. O Estado nacional torna-se a representação dos poderes econômicos do capitalismo monopolista, ao impor uma política de Estado pela força, pela tortura, pela lei ${ }^{20}$ em si e para si, a condição econômica da manutenção das formas de expropriação e das taxas de exploração do trabalho em níveis elevados, além de resguardar as empresas multinacionais instaladas na América Latina de uma concorrência internacional na forma de leis protecionistas. Tais medidas possibilitaram que a desigualdade socioespacial, econômica e, porque não dizer política, mantivesse as taxas de lucro em níveis aceitáveis na esfera mundial de acumulação. Calar as demandas sociais, criar a representação do progresso como forma de ascensão social, permitir pela via da mais pura violência as taxas de acumulação do capital monopolista, foram os preceitos dos estados ditatoriais latino-americanos. A desigualdade, cuja aparência remete ao progresso como forma de sua supressão, é na verdade produzida, pois que a simultaneidade progresso e atraso é o véu que encobre a violência pressuposta da inserção dos milhões de indivíduos às engrenagens da reprodução capitalista.

${ }^{20}$ O Ato Institucional no 5, de 13 de dezembro de 1968 imposto pelo governo militar aqui no Brasil, que suprimia direitos políticos e civis, foi um claro exemplo deste processo. 
Os nexos na produção em escala mundial são complexos e de difícil apreensão. Resumidamente, a produção incessante de tecnologias voltadas aos processos industriais conduziu a uma divisão do trabalho que simultaneamente difundiu formas muito avançadas e ao mesmo tempo bastante precárias de produção. A composição orgânica do capital no que tange aos seus componentes variável e constante apresenta-se em espectro amplo, muitas vezes no interior de uma mesma região, mas sempre combinando formas aparentemente desiguais de produção. Voltemos ao caso do Brasil, exemplar neste aspecto, pois que o "desenvolvimento" centrado nos processos urbano-industriais do centro-sul, principalmente em São Paulo na segunda metade do século XX, se define pela divisão do trabalho que compõese pela incorporação da Região Nordeste, sempre remetida ao "atraso" e às relações arcaicas mantidas por "coronéis". Esta Região se integrava à economia mundializada pela divisão territorial do trabalho mantida pelo centrosul urbano-industrial por meio da expropriação grupos sociais no campo e de sua incorporação como força de trabalho ao centro-sul, processo garantido pelas condições estruturais da propriedade privada da terra e, em muitos casos, pela violência pura e simples de uma burguesia fundiária personificada pelos coronéis e seus exércitos particulares, o jagunços, representações de um arcaico, mas perfeitamente combinadas com as relações sociais da reprodução capitalista naquele momento e naquele espaço ${ }^{21}$. Tais personas acabavam por se apresentar também como o Estado ${ }^{22}$, cuja presença era a ausência. Façamos como Henri Lefebvre, pensemos neste caso, no Estado como uma presença-ausência. Sua ausência se situava em sua representação pelas classes dominantes regionais que assumiam sua forma e suas atribuições. Tanto é assim que os coronéis e suas milícias, e não a instituição Exército Brasileiro, se incumbiram da opressão e do massacre às ligas camponesas nordestinas durante a ditadura civil-militar no Brasil. Por outro lado, o Estado se incumbia das formas de planejamento que possibilitavam a inserção do Nordeste na divisão internacional do trabalho por meio da construção das infraestruturas necessárias à integração territorial ou, se preferirmos, pela

\footnotetext{
${ }^{21}$ Ver OLIVEIRA, F. de, 2008 (1977), op. Cit.

${ }^{22}$ Ver o trabalho de Carlos de Almeida TOLEDO: "A Região das Lavras Baianas" (Tese de Doutorado, São Paulo, FFLC-USP, 2008) sobre o papel dos Coronéis como personificações necessárias do Estado e do capital na Região Diamantina da Bahia.
} 
objetivação dessas estruturas na forma de capital fixo, este que se realiza após incontáveis rotações numa relação direta com o capital circulante que the consome $^{23}$. Por este motivo, é deixado à custa do Estado como socialização de suas dívidas. A presença estatal se fazia por sua ausência, ao mesmo tempo em que essa ausência permitia a presença em outras formas estruturais.

E dessa maneira, ao produzir simultaneamente diferenciações intrínsecas à divisão internacional do trabalho, o processo produtivo mundial cria uma combinação desigual no interior da qual se redefinem os termos da composição orgânica do capital. Tais combinações são, na verdade, uma busca por situar os patamares de acumulação em níveis elevados, mas que, no interior do próprio processo, tornam-se cada vez mais críticos e suscitam essa combinação desigual na busca por novas possibilidades de formação de capital, centradas na condição de acumular espaços, produzir contingentes precários de força de trabalho, a partir de um movimento que combina variados meios de expropriação definidos por formas semelhantes a uma sempre presente acumulação primitiva. Combinam-se, na verdade, crise e acumulação, a leitura necessária do processo de acumulação como crítico e, dessa maneira, exposto a um movimento que relaciona desigualmente formas produtivas e financeiras, espaços de grande complexidade no interior dos quais há uma necessária relação entre o "atrasado" e o "avançado". A leitura dos desiguais se apresenta, portanto, na apreensão de um movimento dialético, cuja relação negativa entre os desiguais resulta na própria condição negativa do processo.

No quadro atual da produção de mercadorias, o qual alguns autores denominam de acumulação flexível ${ }^{24}$ a partir de condições de concorrência, de gestão e tecnológicas muito diferentes de momentos anteriores ${ }^{25}$, o trabalho como categoria do capital permanece sob a lógica da separação, mas se redefine no interior dessa nova condição da produção, cuja tendência a uma

\footnotetext{
${ }^{23}$ Sobre a relação capital fixo $x$ capital circulante ver HARVEY, 1990 (op. Cit.).

${ }^{24}$ Nas obras de David HARVEY, (1982 e 2004, op. Cit.) essa transição de um período de grande crescimento e níveis elevados de emprego e remuneração nos países centrais é chamado de "Fordismo", contraposto a outro período que se segue, também de grande produtividade mas de precarização das condições de trabalho, terceirizações, subempregos, redução salarial, além das mudanças nas políticas estatais para o chamado neoliberalismo.

${ }^{25}$ Francisco de Oliveira, por exemplo, denomina de "Molecular-Digital", cuja eficiência se consolida em bases cada vez menores de circuitos (nanotecnologia) assim como bases moleculares mesmo, sobretudo na agroindústria e na indústria farmacêutica (OLIVEIRA, F. 2003 p. 135, op. cit.).
} 
cada vez menor parcela de extração de mais-valia atinge níveis críticos contrapostos a uma cada vez mais intensa produtividade. As reestruturações nos processos de trabalho buscam manter a remuneração do capital por formas cada vez mais extensivas de exploração. Desse modo, a reprodução capitalista passa também por metamorfoses. Tudo (ou quase) indica que a remuneração dos capitais está cada vez mais dependente da sua forma financeira em detrimento das formas produtivas. Acontece que essa forma financeira passa também a realizar-se sem uma realidade que the dê fundamento, pois há uma crise de realização da mais-valia a qual redefine toda a condição de sua repartição, ou seja, que as formas de remuneração tanto da propriedade da terra como do dinheiro também se fazem críticas nesse momento. Mesmo assim, os adiantamentos de capital para a produção e/ou comércio de mercadorias em geral tornam-se cada vez maiores, o que implica supor uma cada vez mais intensa forma fictícia pairando sobre o mercado da circulação financeira. O financeiro passa então a uma condição primordial na manutenção da reprodução, mas se torna também necessário que a própria reprodução se metamorfoseie em função desse processo crítico.

A compreensão dos processos socioespaciais na contemporaneidade passa pelas transformações na reprodução do capital em escala mundial, sobretudo a partir das ultimas décadas do século XX. De momentos tidos como de "grande crescimento econômico" embasado numa produtividade industrial que explorou intensiva e extensivamente vastos contingentes da força de trabalho, processo cunhado no Brasil da década de 1970 de "milagre econômico", a reprodução do capital situa-se atualmente sob condições outras que redefinem os processos e a escala mundial da reprodução. O novo "estilo de acumulação é dado pelas novas formas de centralização de gigantescos capitais financeiros, cuja função é frutificar principalmente no interior da esfera financeira" (CHESNAIS, 1996 p.14-15).

A reprodução capitalista tem sido acompanhada pelo desenvolvimento de um sistema creditício a partir da concentração e controle de grandes massas de "capital possível" 26 nas mãos de grupos privados e públicos,

${ }^{26}$ Designação dada por Karl Marx ao capital que pode ser inserido na produção por meio de empréstimo, cuja "latência" de refluir acrescido de parcela da mais-valia, ou seja, da condição 
fundamentalmente bancos, a partir de um controle cada vez maior por parte dessas instituições tanto de fundos de reserva como de poupança que tornamse, por esse controle e concentração, "fundo comum", o qual se realiza a partir de investimentos produtivos e da repartição que Ihes cabe da mais-valia global como juro ${ }^{27}$. Historicamente, tem-se por princípio desse processo que "essa parte do capital monetário, a qual de outro modo ficaria ociosa como fundo de reserva, é emprestada, funciona como capital portador de juros" (MARX, 1988 p. 287), ou seja, dinheiro disponível ou capital sobreacumulado não pode ficar ocioso. Integrá-lo aos circuitos de reprodução como meio de pagamento, como meio de circulação, na forma de adiantamentos, de financiamentos, de crédito, de papeis em geral, torna-se primordial para que este se mantenha na circulação e dessa maneira possibilite sua reprodução na forma de mais dinheiro, tal como é seu movimento histórico. A compreensão desse movimento "no processo real de circulação aparece sempre apenas como mercadoria ou dinheiro". No entanto, embora possua um "caráter específico como capital portador de juros, lançá-lo na circulação torna-o mercadoria como capital [...] como valor que possui o valor de uso de criar mais-valia" (Idem, p. 244-5), processo este que se explica no movimento geral do capital:

Que esse dinheiro seja aqui ao mesmo tempo capital monetário, uma forma do capital não decorre do ato da compra, da função real que aqui exerce como dinheiro, mas da conexão desse ato com o movimento global do capital, pois esse ato que realiza como dinheiro inaugura o processo de produção capitalista (Ibidem).

Embora para os estudos de Karl Marx esse capital portador de juros se define pela repartição da mais-valia, por sua condição de tornar-se ele mesmo meio de produção, ou seja, relacionar-se à exploração de força de trabalho, o autor já apresenta em seus estudos mecanismos que extrapolam a compreensão dessa concentração de dinheiro relativamente à sua base produtiva, o que, para o caso por ele estudado, das letras de câmbio, torna "impossível decidir quantas delas provém de negócios reais" (LEATHAM, W. 1840 apud, MARX, idem, p. 285-6), ou seja, nesse momento de sua análise,

de tornar-se capital inserido no processo de exploração da força de trabalho Ihe torna "capital possível" (MARX, K. 1988 p. 241-2).

27 Uma história desse processo de acumulação de capital financeiro e sua condição monopolista encontra-se na obra de Vladimir I. Lenin (LENIN, 2012, op. Cit.). Ver também MARX, 1988 (op. Cit.), p. 255-318. 
Marx nos fala de um "capital fictício". Com base em vários relatórios de bancos e auditorias fiscais da primeira metade do século XIX, é possível verificar pela leitura do autor que já se manifestam situações de multiplicação desses títulos de dívidas para além de sua base real, o sistema produtivo.

A produção diferencial e combinada desde meados do século $X X$ possibilitou grande acumulação centralizada em determinadas áreas do globo, personificadas nas mãos de grupos privados, sejam industriais ou financeiros, amparados por poderes estatais em diferentes escalas, desde entidades municipais até países, cuja grande expressão é os Estados Unidos. Veja-se a política de investimentos estadunidense do pós-guerra, os chamados Planos Marshall e Colombo, "fundos perdidos" destinados à "reconstrução" dos países da então Europa Ocidental e do Japão, assolados pela Segunda Guerra. Para alguns autores como David Harvey (HARVEY, 2004), neste período se situa uma problemática de sobreacumulação de capital, ou seja, há uma grande massa de capital possível, disponível aos diversos segmentos da produção mundial, ao mesmo tempo em que dinamizados por políticas globais de entidades financeiras surgidas no pós-segunda guerra, como é o emblemático Fundo Monetário Internacional (FMI) ou o Banco Mundial. Atrela-se a essa realidade, outra que se situa no plano político global, mas que se define por meio de "potências" desse poder político, como é o caso, mais uma vez, dos Estados Unidos, as quais difundem nessa ordem política imposta o acesso aos créditos dessas instituições ao mesmo tempo em que definem quais as formas de investimento que devem ser adotadas por estes países "devedores".

$O$ fato é que tais condições impulsionam uma financeirização desmesurada a qual se supõe, atrelada à ficcionalização da reprodução capitalista. Dizemos ficcionalização pois esta torna-se premente nesse circuito uma vez que nem todo dinheiro adiantado retorna como mais dinheiro lastreado por uma correspondência da produção da mais-valia global. $O$ dinheiro torna-se mais dinheiro sem necessariamente passar pelo processo produtivo:

O desenvolvimento espantoso de uma economia especulativa indica que o capital não encontra mais aplicação lucrativa no campo produtivo, o que torna evidente uma crise de sobreprodução. Três dias de transações financeiras mundiais equivalem ao montante do conjunto do comércio mundial; três dias de transações monetárias em Londres são equivalentes 
ao produto anual do México! Outro índice desse desenvolvimento do capital fictício é o crescimento do endividamento: apesar de todos os anúncios de superação da crise da dívida externa, a dívida externa dos países de terceiro mundo cresceu de 500 bilhões de dólares em 1975 até quase 2 trilhões na atualidade [...] Na principal economia capitalista do planeta, responsável pela segurança do conjunto, os EUA, a dívida pública atinge atualmente a casa dos 5 trilhões de dólares! (COGGIOLA, 1996 p. 198-9).

Os adiantamentos de capital necessários à sua própria expansão, nas suas diversas formas, sejam capitais fixos ou circulantes, cujo resultado se pode verificar no aumento significativo das movimentações financeiras mundiais, de suas quantidades no mundo dos negócios, e de suas consequências, tais como o aumento significativo das dívidas dos países, passou a produzir toda sorte de títulos e a predominância de um mercado mundial desses papéis cada vez mais intensivo e extensivo, ao ocupar as mais variadas esferas da reprodução do capital em geral. Passam estes capitais a se realizar a partir da forma financeira, ao ampliar cada vez mais o mercado de dinheiro para financiar seus diferentes campos de atuação ${ }^{28}$.

Ocorre que o movimento financeiro, a mercantilização do dinheiro, suas formas de adiantamento, dão um sentido mais especulativo do que produtivo para a reprodução, processo que resulta na dimensão de uma sobreacumulação de dinheiro fictício, tornado capital fictício, pois que move o processo de acumulação, oriunda da produção, também fictícia, de mais dinheiro e de mais dívidas ${ }^{29}$. Temos, simultaneamente, condições de

${ }^{28}$ O trabalho de Gilberto Dupas "Economia Global e Exclusão Social" (São Paulo: Paz e Terra, 2001) traz inúmeros dados sobre a financeirização. Ao contrário do que apregoam os ideais neoliberais, os gastos estatais dos países centrais (OCDE) tem aumentado relativamente ao PIB pela intensificação de pagamentos de juros, transferências e subsídios (p. 107-9). Outra informação é o envolvimento cada vez maior de setores produtivos com produtos financeiros, como é o caso das grandes montadoras de automóveis, FORD e GM, e gigantes do setor elétrico, GE, entre outros exemplos, que oferecem um leque amplo de produtos financeiros: fundos, seguros, cartões de crédito, hipotecas, e por aí vai. (pp. 41-5).

${ }_{29} \mathrm{Em}$ alguns momentos, nem uma coisa nem outra, por exemplo, na chamada "crise do subprime" ocorrida nos EUA de 2009, na qual os adiantamentos na forma crédito imobiliário para setores da classe média estadunidense não retornaram aos bancos como mais dinheiro, fato que causou o chamado "estouro da bolha financeira". Como resultado, os devedores foram espoliados de seus imóveis e, no país considerado "mais rico do mundo", formou-se uma multidão de home lesses de classe média da noite para o dia; e, claro, o socorro do Estado aos bancos veio com bilhões de dólares para "salvar" os outros investidores e manter a "calma" do mercado.

Em 2011 tivemos outro fato importante a esse respeito. O Congresso dos EUA, sob acirradas negociações envolvendo inimigos políticos históricos, Democratas e Republicanos, aprovou a elevação do teto da Dívida Pública do país, o qual está referenciado por Atos Institucionais que 
acumulação pressupostas por adiantamentos de capital financeiro, e crise por reprodução deste mesmo capital na forma fictícia:

\begin{abstract}
Atualmente, essa perda de impulsos internos na reprodução ampliada do capital manifesta-se adicionalmente na magnitude dos fundos improdutivos requeridos pela esfera financeira para sustentar a produção corrente, ou na ingerência sem precedentes dos Estados no mundo do trabalho com o intuito de assegurar a extração de mais-valia. (KATZ, C. 1996 p. 255).
\end{abstract}

Por outro lado, é necessário pensar também que o próprio sistema produtivo mundial também se revela crítico, uma vez que torna-se, pela concorrência e tecnologia dela resultante, cada vez mais difícil remunerar os capitais investidos a partir das taxas de mais-valia. Este pressuposto se define a partir de contradições primordiais do processo histórico capitalista entre forças produtivas e relações de produção. Tais condições amparam as dificuldades de remuneração do próprio capital a partir de taxas de lucro cada vez menores. Alguns autores apontam para uma crise pressuposta pela produção do valor, ou seja, o capital em vias de perder sua substância.

Ao pensarmos no movimento de reprodução do capital pelas relações contraditórias postas historicamente, há tempos a contradição entre as forças produtivas e as relações de produção se constitui "no fato de que, através do aumento da produtividade e da racionalização, se produz por produto e por utilização de capital um valor cada vez menor" (KURZ, 1997 p. 112). Robert Kurz aponta para uma crise de produção do valor e de valorização na esfera produtiva dinamizada por fatores como:

... a racionalização microeletrônica pós-fordista e a globalização dos mercados de mercadorias e de trabalho e dos mercados financeiros fizeram com que quantidades tão grandes de trabalho se tornassem não rentáveis [...] chegou ao ponto no qual não se pode mais mobilizar rentavelmente quanta suficientes de trabalho no patamar dos padrões de produtividade, criados pela própria sociedade. (idem p.113).

Embora as relações de produção se tornem cada vez mais críticas, ao mesmo tempo e como resultado dessa mesma crise, se fincam cada vez mais em processos de precarização do trabalho, os quais tornam-se mais extensivos quanto à exploração, sempre repondo, explorando e precarizando contingentes

necessitam ser aprovados no Congresso para mudanças em suas quantidades, uma vez que 0 teto do endividamento público do país, de aproximadamente 15 trilhões de dólares, foi superado em mais de 150 bilhões de dólares. 
cada vez maiores de trabalhadores, ainda que se apresente um movimento que vai da produção industrial das grandes plantas (há permanências dessas formas, por exemplo, nos casos de produção industrial na China e na Índia) para outras formas de trabalho, principalmente os serviços terceirizados e desregulamentados $^{30}$. O momento atual pelo qual passa a reprodução do capital redefine as relações sociais de produção de maneira que mesmo estas passam a constituir um movimento crítico, no qual as condições da concorrência, da expansão tecnológica, da racionalização, enfim, da produção em si e da produção do valor constituem o próprio movimento crítico e expõem os liames da contradição entre as forças produtivas e as relações sociais de produção:

As crises aparecem então como o único meio eficaz de contrabalançar os desequilíbrios, de restaurar o equilíbrio entre a produção e o consumo. Mas, essas crises trazem consigo a desvalorização, a depreciação e a destruição do capital. E este nunca tem sido um processo com o qual se possa viver de forma cômoda, particularmente porque também traz consigo a desvalorização, a depreciação e a destruição do trabalhador. (HARVEY, 1990 [1982] p. 105).

No entanto, é sempre importante reiterar a permanência de um processo que busca condições cada vez mais extensivas de exploração do trabalho na tentativa de remuneração do capital. Mas ao mesmo tempo, quanto mais essas condições se tornam críticas, mais fictícia é a forma fundamental da reprodução baseada nas demandas creditícias do dinheiro.

É importante situar também a condição histórica do Estado na esfera financeira e, na atualidade, primordial para a reprodução a partir da emissão dos títulos públicos que "representam a espinha dorsal dos mercados de obrigações mundiais. Seu volume de transações supera, de longe, o de qualquer outro segmento dos mercados financeiros, com exceção dos capitais de câmbio". (FMI, 1994 p.34, in CHESNAIS, op. cit. p 248).

Nestes termos, o Estado permanece com o seu papel dinamizador da acumulação, mas se reestrutura em função das novas condições da divisão do trabalho. Para alguns autores, essas novas condições se impõem, ao contrário

\footnotetext{
${ }^{30}$ No texto intitulado "Século XXI, nova era da precarização", Ricardo Antunes levanta algumas formas do trabalho no mundo atual consideradas a partir das novas condições impostas pela desregulamentação e outras formas que, segundo o autor, vigoram a partir da década de 1970, ampliando-se no começo do século XXI. Ver Ricardo ANTUNES e Ruy Braga: Infoproletários. São Paulo: Ed. Boitempo, 2009.
} 
de momentos anteriores nos quais "o crédito estatal cresceu em conjunto com o trabalho produtivo nas indústrias, o que possibilitou ao Estado recolher mais impostos justos e custear seus gastos cada vez maiores" (KURZ, 1997 p.131), em condições outras que resultam desse novo momento de rearranjos nas formas de reprodução, agora centradas principalmente no capital financeiro que se apresenta nas últimas décadas de maneira a sustentar a reprodução do capital em escala mundial, fato que situa a dívida pública num patamar também central de sustentação da reprodução a partir da emissão de títulos. Os gastos estatais buscam sustentar os atuais níveis de desenvolvimento das forças produtivas sociais, pois:

[...] o nível civilizatório da infraestrutura, da formação profissionalizante e da ciência, da saúde pública, dos meios de transporte público, da eliminação do lixo e dos resíduos, etc., não é um luxo, mas uma necessidade para manter em funcionamento a própria acumulação de capital (idem, p.109).

Robert Kurz faz considerações sobre um processo mundial, mas que precisamos considerá-lo como fragmentado. No caso brasileiro, o processo de acumulação dinamizado pelo Estado, principalmente com as políticas de sustentação ao processo industrial, desde a década de $1930^{31}$, não possibilitou o mesmo resultado do que foi dito anteriormente, ou seja, "recolher impostos e custear seus gastos". Ao contrário, o endividamento estatal, e portanto social, sempre correu ao lado da acumulação privada, fato que inclusive gerou significativos momentos de crise, como aconteceu a partir de meados da década de 1970, em pleno "milagre econômico" (taxas de crescimento do PIB na média de $10 \%$ ao ano), o endividamento e o processo inflacionário resultantes do financiamento público passaram a redefinir as formas de representação política das classes dominantes. De qualquer maneira, nunca passamos por um "welfare state" como foram os casos europeu, estadunidense e japonês.

${ }^{31}$ Consideramos aqui o Estado como sustentáculo do capital fixo, das grandes estruturas necessárias à divisão do trabalho pressupostas nas fases mais promissoras da industrialização brasileira. Se considerarmos o Estado em momentos anteriores, como a industrialização em São Paulo a partir de meados do século XIX, o Estado já é fundamento com seu endividamento, mas principalmente na forma variável do capital, do financiamento à migração, ao disponibilizar dessa maneira a força de trabalho necessária. 
Nos termos do imperialismo como forma política e de poder regulador mundial ${ }^{32}$, nosso Estado procura viabilizar, via remessa de lucros, as taxas de acumulação mundiais. Pela via do endividamento e do planejamento, o Estado possibilita as formas de acumulação privada, embora haja limites ao processo, como foi a crise do regime civil-militar em fins da década de 1970. A partir daí, transformações profundas nas relações trabalho-capital buscam formas de realização do capital por meios que precarizam mais ainda o trabalho na busca por remunerações à produção e aos investimentos. Por outro lado, a via da produção do espaço passa a compor cada vez mais as formas de reprodução. Um ponto desse processo é o aprofundamento da relação entre o financeiro e o espaço por vias diversas, como é o financiamento para o caso do Pantanal. No entanto, tais condições também aprofundam o processo crítico, pois que surgem outras contradições para as quais são necessárias novas análises.

\footnotetext{
${ }^{32}$ Voltemos à obra de Vladmir I. Lênin, "Imperialismo, fase superior do Capitalismo" (op. Cit.).
} 


\section{Capítulo III}

\section{A Financeirização na Relação Capital-Espaço}

Todo esse apanhado de uma crise na reprodução capitalista nos remete a pensar quais seriam os meios pelos quais o capital em geral, mas sua forma financeira principalmente, possa se realizar mesmo como ficção? Quais as formas atuais necessárias para que se sustentem os investimentos financeiros? Neste e por este movimento, a produção de espaço reitera as condições da reprodução do capital ao definir novas lógicas constitutivas das relações sociais de produção. Embora haja diversas condições espaciais dessa territorialização do capital, o urbano e sua contingência como espaço construído, como massa de capital fixo, como imperativo de infraestruturas, mas também passível de destruição e expropriação, torna-se um importante atrativo para os investimentos financeiros. Podemos pensar no capital fixo, como organizador do espaço, no sentido de racionalizá-lo para permitir o aumento da exploração do trabalho.

No urbano, há um significado para a produção do espaço que não se limita à realização os investimentos. O urbano é em si uma estrutura produtiva, uma forma a partir da qual a racionalidade da produção, da circulação, do consumo se combinam, pois:

[...] contém uma parte importante do trabalho passado e fixado, literalmente morto, de que o capitalismo dispõe para se apoderar do trabalho vivo, o que ela contém sobrevive deste modo ao desgaste cotidiano dos instrumentos de trabalho; mantém, à maneira de uma instituição, a divisão do trabalho indispensável ao funcionamento do capitalismo por consequência mantém e aperfeiçoa no seu seio a divisão social do trabalho (LEFEBVRE, 1972 p.132-3).

Mas o urbano é também forma que propicia o próprio conteúdo do capital de se realizar como processo dominante, de manter em seu interior condições elementares da subsunção do trabalho ao capital:

A cidade é, de pronto, o fato da concentração da população, dos instrumentos de produção, do capital, das fruições, das necessidades [...]. A oposição entre cidade e campo só pode existir no interior da propriedade privada. É a expressão mais crassa da subsunção do individuo à divisão do trabalho, a uma atividade determinada, a ele imposta [...]. O trabalho é, aqui, 
novamente o fundamental, o poder sobre os indivíduos, e enquanto existir esse poder tem de existir a propriedade privada (MARX \& ENGELS, 2007 p.52).

No urbano significativas metamorfoses do processo capitalista relacionaram historicamente o que é móvel e o que é imóvel, numa lógica transformadora para as formas do capital. As metamorfoses da propriedade privada do solo urbano condicionadas por novas possibilidades criadas no interior da modernização têm como lócus político e institucional o espaço urbano, no interior do qual a metrópole de São Paulo é exemplo significativo. São redefinições jurídicas e políticas que metamorfoseiam as formas da propriedade privada do solo urbano diante de condições nas quais esta tornase, ela própria, processo e limite à reprodução pela via da inversão de capitais no espaço urbano propriamente dito.

Henri Lefebvre (1972) desenvolve a metamorfose da propriedade fundiária em propriedade privada moderna num processo histórico no qual as parcelas do solo ganham sentido não somente como capital imobiliário, mas como capital mobiliário. Nesse contexto, a cidade é, simultaneamente, local, instrumento e teatro desta gigantesca metamorfose, a partir da necessidade de que, no espaço urbano, a propriedade sobreponha à sua forma imobiliária outra forma, mobiliária, ou seja, que este capital imobilizado na propriedade, numa específica porção da superfície terrestre, se mobilize no espaço. "Daí a tendência disso que outrora foi o "imobiliário", doravante "mobilizado" (construções, especulações) tornar-se central no capitalismo" (LEFEBVRE, 2008 p.118). Para o atual momento na metrópole de São Paulo, a forma propriedade do solo urbano se ajusta cada vez mais aos referenciais financeiros, estes que passam a representá-la no mercado mundial de títulos cujo preço se define não mais somente pelas circunstâncias locais, mas como referencial aos preços internacionais nos mercados financeiros.

Esta forma, mobiliária e imobiliária ao mesmo tempo, se sustenta no espaço como, à semelhança dos capitais que nele incidem, ele mesmo fiduciário, promessa de realização futura, seja pelas transformações objetivas no espaço da metrópole, seja pelas condições que a propriedade assume como título no mercado financeiro, seja pela junção de uma e outra. O recorte e a costura desse raciocínio são dados não somente pelo mercado, mas também 
pelas intervenções jurídicas e políticas na forma da propriedade privada, inserida em perímetros específicos do espaço metropolitano. A partir de definições jurídicas do Estado respaldadas pelo planejamento urbano e, para o caso do Pantanal da Zona Leste, em consideração aos fortes apelos ambientais reforçados pelas condições de risco social, a institucionalização do espaço revela um movimento pelo qual se define a expropriação dos moradores, à custa dos quais se realizam os novos negócios na metrópole como possibilidade da financeirização do espaço.

A produção do espaço urbano combina meios de exploração do trabalho com formas de remuneração de investimentos financeiros. A destruição é uma característica desse processo. Ela passa de simbólica, aquilo que não representa mais nada diante dos "avanços" da modernização; para efetiva, aquilo que não serve mais e que deve ser destruído. Em sua tese de doutorado, Ana Fani A. Carlos (2001) encontra os limites da reprodução do capital em suas próprias categorias fundamentais, como é o caso da propriedade privada do solo urbano. Uma vasta região no sudoeste da cidade de São Paulo passou por transformações de ordem jurídica que implicaram em uma radical expropriação/despossessão de um vasto contingente de moradores de diversos níveis de renda; terra arrasada, destruição de inúmeros quarteirões com o sentido de recolocar as condições da reprodução centrada na relação capital-espaço, ao fazer a propriedade mudar de mãos pela via da expropriação/despossessão consubstanciada na mudança da legislação urbanística, pela inclusão desta área nos perímetros das novas modalidades institucionais e jurídicas do planejamento, as Operações Urbanas.

Sempre houve uma relação primordial entre a reprodução do capital e o espaço, sobretudo como forma desigual, como possibilidade de expansão das fronteiras do "progresso", da construção das estruturas necessárias à constituição do "moderno", do atual, do contemporâneo, objetivados e ao mesmo tempo simbolizados por edifícios modernos, prédios inteligentes, pontes e over-drives (as "impressionantes esculturas de lama" que chamaram a atenção do compositor Chico Science); enfim como possibilidade, na condição urbana, de se dispor à reprodução nas variadas esferas do capital:

Quando a cidade não é só continente da atividade industrial mas a urbanização propõe, enquanto tal, a presença da 
indústria, espacialmente a da construção e seu aparato -, a cidade cresce, crescendo também como negócio industrial: os subterrâneos produzidos, a verticalização, os viadutos e tantos outros produtos da urbanização (DAMIANI, 2000 p. 28).

Definir o espaço como, ele mesmo, produto industrial, de relações de produção no campo da construção civil, implica também a busca do capital pela produção da mais-valia por meios cada vez mais precários de trabalho. 0 "encontro com o peão ${ }^{33}$ " o qual Amélia Damiani nos conta em sua dissertação de mestrado em meados da década de 1980, não cessa em nossos tempos. Ao contrário, intensifica-se nos cada vez mais presentes alojamentos de trabalhadores da construção civil, onde essa precarização se desenrola, sempre a renovar seus contingentes, a buscar novas fontes na tentativa de manter a mais-valia a partir de condições de exploração que parecem revelar um passado remoto, o mesmo da época em que a autora fez sua pesquisa, década de 1980, mas que estão cada vez mais presentes no "boom" da construção civil nas metrópoles brasileiras das primeiras décadas do século XXI. São outros os lugares das fontes da força de trabalho precária, Maranhão, Piauí, Bolívia, Peru, Nigéria, Haiti, mas as mesmas formas de exploração, baseadas na sujeição, na violência, os mesmos exemplos que outrora serviram para pensar num peonato da construção civil, permanecem nesta indústria na busca por remuneração aos capitais investidos.

No entanto, é necessário pensar também na condição financeira que a indústria da construção civil lança mão atualmente. É, principalmente, no próprio mercado de terras atrelado ao mercado financeiro que se desenrolam as formas contemporâneas assumidas pela relação capital-espaço. Incorporam estes elementos outras configurações nos atuais processos de produção do espaço, pois que se apresentam também:

[...] como puro bem financeiro, imerso no movimento do capital como uma corrente de valor, que envolve toda ordem de

\footnotetext{
${ }^{33}$ Dissertação de Mestrado da Professora Amélia Damiani que revela formas de exploração de trabalho baseadas em mecanismos de sujeição e violência, tais como manter uma espécie de cárcere dos trabalhadores no alojamento, cobrar taxas por "alojamento", uso de ferramentas, se apropriar da documentação como forma de manter o trabalhador sujeitado ao "gato", o intermediário entre a construtora e o empreendimento, enfim, as condições de exploração do trabalho aparatadas por outras formas de intensificar ainda mais a extração de mais-valia (Ver Amélia Luisa DAMIANI: "Na busca das favelas o encontro do "peão" que permanece : as favelas de Cubatão num quadro de desenvolvimento do centro petroquímico siderúrgico". Dissertação de Mestrado, FFLCH-USP, São Paulo, 1984)
} 
especulações com a terra. Trata-se do controle de um direito sobre rendimentos futuros previstos (DAMIANI, 2000 p. 41).

Alguns trabalhos apontam a relação entre os investimentos financeiros e a produção do espaço em São Paulo. Percebe-se que grandes massas de capital buscam sua realização a partir de empreendimentos imobiliários, tanto na compra de terrenos como na produção de edifícios. O espaço torna-se possível meio de remuneração desses capitais:

[...] a maior parte dos megaprojetos em São Paulo são dos fundos de pensão, entidades de previdência privada regulamentados no fim da década de 80 (que na verdade já existiam desde 1970, quando foi criada a Petros, Fundação Petrobras de Seguridade Social). Os imóveis fazem parte da carteira de investimentos dos fundos juntamente com ações, depósitos a prazo, fundos de investimento e outros tipos de aplicação [...] o patrimônio dos fundos é cerca de 98 bilhões de dólares, movimentando cerca de $11,5 \%$ do Produto Interno Bruto do País (FIX, M., 2001 p. 23).

Portanto, para entender a produção do espaço na atualidade, é necessário pensar na reprodução do capital na esfera financeira, pois "o capitalismo, longe de prescindir do espaço, realiza-se a partir e por meio deste" (CARLOS, 2005 p.30). Os novos negócios urbanos, a produção do espaço em si, pressupõem inversões de capital financeiro que se territorializam e diferenciam os lugares do ponto de vista dos investimentos, assim como produzem este espaço enquanto fragmentos, lugares segundo uma hierarquia cujas bases se estabelecem quantitativamente a partir desses investimentos que dinamizam "o espaço como momento significativo e preferencial da realização do capital financeiro" (idem, p.32).

O movimento do capital financeiro no e pelo espaço se constitui a partir de mudanças nos elementos da reprodução definidos anteriormente de maneira contundente pela relação capital-trabalho, mas que, nas condições atuais, convergem cada vez mais para a relação capital-espaço enquanto "mudança dos investimentos da produção para a especulação no mercado de ações a globalização das finanças e o novo nível de engajamento delirante com os valores imobiliários" [...] (JAMESON, 2001 p. 183).

Tal movimento acontece há tempos nas metrópoles dos chamados países centrais, metamorfoseando o espaço a partir das mudanças estruturais nas formas de reprodução do capital (o que de certa forma corrobora com 
nossas especulações acima a respeito dos limites à remuneração dos capitais produtivos), que nestes casos, se definem claramente como espaciais, pois que operam de maneira a relacionar:

[...] o movimento da renda fundiária e o movimento da capital financeiro que é organizado em torno dela são elementos estruturais permanentes do sistema, às vezes assumindo um papel secundário e insignificante, às vezes, como no nosso período, vindo à tona como se fossem o principal centro da acumulação capitalista (idem p. 199-200).

São várias as formas pelas quais tais investimentos perpassam a produção do espaço. Para o caso brasileiro mais recente podemos apontar, por exemplo, a formulação em 1997 de um novo sistema de aquisição de imóveis financiados, o Sistema Financeiro Imobiliário (SFI), cujas formulações se justificam pelo "déficit habitacional", mas que implica numa relação intrínseca entre o consumo do espaço e a produção fictícia de valores imobiliários a partir dos juros correntes no mercado, ou seja, aprofunda a relação entre o financeiro e o espaço a partir da justificativa daquele como necessidade social para "resolver o déficit habitacional" 34 .

Por outro lado, o aprofundamento da relação entre o capital financeiro e o espaço urbano significa que as próprias condições da metropolização passam a se produzir, além de outras formas, também a partir desta relação. Esse processo redefine as formas da apropriação do espaço urbano, assim como as da expropriação. São diversas metamorfoses que reestruturam a dinâmica dos conflitos em torno da moradia a partir de lógicas que perpassam desde a espacialização dos investimentos até a própria forma propriedade. Isso aprofunda a lógica espacial da fragmentação e dispõe o espaço da metrópole de maneira que este possa produzir outras condições para a remuneração dos investimentos.

As reestruturações no espaço urbano não são algo atual e puramente produzido pelos investimentos financeiros. Muitas das transformações em

\footnotetext{
${ }^{34}$ O Trabalho de Luciana Oliveira ROYER: Financeirização da Política Habitacional (São Paulo, Annablume, 2014) faz uma discussão pormenorizada sobre a criação e a trajetória do SFI, suas implicações para o mercado imobiliário e o impulso que cria para a financeirização do consumo imobiliário. Esta autora analisa a formação desse mercado financeiro voltado ao imobiliário a partir da justificativa do "déficit habitacional" como aparência, o que, para ela não passa de um aprofundamento da relação entro o imobiliário e o financeiro como forma de remuneração deste último. Por isso as aspas em "déficit habitacional", que são da própria autora.
} 
termos estruturais nas chamadas periferias da metrópole são resultado de vários processos que perpassam desde lutas sociais de grupos de moradores para o acesso a bens e serviços ${ }^{35}$, até a própria mercantilização do espaço; a segmentação e expansão do consumo, como é o caso dos hipermercados, magazines, redes de lojas de material de construção ao longo das principais vias de ligação das áreas centrais com as periferias (ver Anexo 1 'Mapa 2) ${ }^{36}$, enfim, processos que dinamizaram o espaço da metrópole de maneira a produzir diversas centralidades em áreas até então consideradas longínquas e desprovidas de estruturas ${ }^{37}$.

No entanto, é importante focar no financeiro e nas transformações que este pressupõe. Um estudo sobre São Paulo de Flavia E. S. Martins (MARTINS, 2010) discute a abertura de capitais nas incorporadoras, como o Initial Public Offering (IPO) que permite a captação de recursos a partir de ações comercializadas na Bolsa de Valores de São Paulo. Para a autora, as relações entre a financeirização e o espaço metropolitano impulsionam uma lógica semelhante àquela que chamei de acumulação de espaço, o que ela define como banco de terras que, para responder à produção de valor e ao pagamento da renda de capital adiantado, os níveis de produtividade mantém uma produção em escala. Para que isso ocorra há uma busca por terrenos distantes e de maneira extensiva que gera concorrência entre as incorporadoras e que também se define no embate entre a renda paga ao capital financeiro e aquela que remunera a renda da terra (p. 55-6). O ritmo financeiro passa a ditar a valorização imobiliária, pois a terra "passa a ser vista como bem financeiro e seus títulos de propriedade passam a ser vistos como capital fictício com rendimentos previstos nos ritmos deste capital” (p. 55). Ocorre também uma mobilização socioespacial uma vez que há uma disputa territorial.

\footnotetext{
${ }^{35}$ A esse respeito, ver os trabalhos de KOWARIK, 1994; e CALDEIRA, 2000 (deste último especialmente a Parte III ).

${ }^{36}$ Boa parte dessas vias foram construídas ao longo das décadas de 1980 e 1990 nas várzeas dos rios da Bacia de São Paulo, principalmente por programas como o PROCAV já citado nesta obra.

37 Amélia Damiani desenvolve o conceito de espaços economizados, dados lugares da metrópole dinamizados por grandes investimentos econômicos que acarretam transformações no sentido puramente econômico para tais espaços, varrendo outros significados ou incorporando-os à mercantilização pura. Ver DAMIANI, 2008 (op. Cit.).
} 
Outra condição que isso implica é a relação legalidade/ilegalidade nos terrenos, fato que se embasa diretamente nas questões da propriedade privada. A regularização fundiária torna-se uma lógica necessária e gera também uma mobilização socioespacial pela metrópole:

Embora esse processo ainda seja limitado, parece que algumas dessas regiões (periféricas) estão começando a entrar no mercado imobiliário legal e a passar por um processo de capitalização na produção de moradias, à medida que incorporadores maiores começam a investir e a construir moradias legais, especialmente edifícios de apartamentos (CALDEIRA, 2000 p.239).

Para o caso de São Paulo, é significativo considerar as transformações no espaço como definidas pelas diferentes condições da reprodução do capital, em outros momentos mais centrada em torno da produção, atualmente pressuposta mais pela financeirização. Tal processo é histórico e convém defini-lo no plano das contradições internas da própria reprodução do capital. Nesses termos, os investimentos fundiários, as inversões de capital diretamente sobre a terra, perpassam diferentes fontes de financiamento juntamente com o Estado, este como instituição imprescindível, dinamizador do processo por deter o poder de legislar sobre o espaço em todo este movimento que relaciona diferentes formas de capital na reprodução. É necessário tratar da inserção do Estado como agente estruturador desta relação capital-espaço a partir de sua forma política e de poder, além de assumir aqui, também, importante papel econômico. Para o caso desta pesquisa, é na forma urbana que encontramos a conjugação desses elementos constitutivos da relação capital-espaço, pois que se definem nas políticas urbanas, nas condições de legislar, de criar espaços onde tais relações possam se desenvolver como lógicas de reprodução.

Metamorfoseiam-se, então, as condições de permanência das formas da relação capital-espaço. Resultam deste processo rearranjos nas relações de produção nas últimas décadas, nas quais o Estado se apresenta como condição da reprodução financeira ao definir, pela via do planejamento, entre outras, o espaço como forma dessa reprodução a partir de investimentos nos setores de serviços urbanos, na infraestrutura, ao sustentar aportes financeiros de agências e bancos internacionais, como são, para o caso desta pesquisa, o Banco Interamericano de Desenvolvimento (BID), os Bancos Japoneses, que 
neste caso, financiam a reestruturação da drenagem na metrópole de São Paulo $^{38}$.

Diversas são as formas de inserção destes capitais pela via do planejamento no espaço urbano de São Paulo. No entanto, se definem no plano das condições socioespaciais específicas de um movimento que requer do espaço formas particulares a partir das quais essas definições políticas se condicionam à reprodução pela via dos investimentos financeiros em obras de infraestrutura. $O$ espaço e a sua condição primordial na realização das formas financeiras atuais está pressuposto também pelas suas formas particulares, e essa forma particular do espaço acredito ser a do espaço como fiduciário, como promessa de realização futura para investimentos, o qual se define por sua condição específica enquanto reserva territorial, historicamente constituída na metropolização de São Paulo, os espaços acumulados. Ao tratarmos esta condição por uma forma pura, quantitativa, o espaço em si aparece como raridade atribuída ao fato de não haver mais espaço, de uma ocupação intensiva e extensiva territorialmente. Mas, ao adentrarmos às condições qualitativas, vemos que essa proposição é formal. A condição da propriedade informal, ou seja, como posse, torna-a reserva territorial e ao mesmo tempo espaço fiduciário, aquele do capital possível, pois latente ao processo de expropriação. É o que verificamos no Pantanal da Zona Leste.

A institucionalização dos atributos ambientais expõe as novas formas que o espaço assume na reprodução, ligadas às várias transformações pelas quais as relações sociais de produção passam nos últimos tempos, postas pelos rearranjos na divisão internacional do trabalho. Por outro lado, os termos da atual condição dessa realização na metrópole de São Paulo se fazem por meio da expropriação de populações situadas nas áreas de interesse. Tal situação aparece como momento de uma regulação jurídica que determina as formas de ocupação a partir de zoneamentos planejados de acordo com normas que buscam um ordenamento do espaço. No entanto, se apresenta a partir de nexos que dão significado ao espaço como possibilidade de realização

${ }^{38}$ O Projeto Tietê (1992) e o Plano Diretor de Macrodrenagem da Bacia do Alto Tietê (SÃO PAULO, 1999, op. Cit.) receberam aportes financeiros do BID e dos Bancos Japoneses a partir do acordo para a reestruturação da drenagem urbana na Bacia do Alto Tietê. Ver Plano Diretor de Macrodrenagem de São Paulo. Governo do Estado de São Paulo: Secretaria de Recursos Hídricos - Departamento de Águas e Energia. São Paulo, 1999 
do capital na sua forma financeira, a partir de investimentos que reestabelecem os usos, incluindo a expropriação de moradores das áreas de interesse.

$\mathrm{Na}$ relação capital-espaço na metrópole emerge a moderna forma da propriedade privada do solo como fundamento. A afirmação da metrópole contemporânea como possibilidade da realização do capital se expressa através da expropriação consubstanciada nas metamorfoses de uso do espaço, postas pelas contradições internas desta mesma realização.

Dessa maneira, verificamos que de formas de acumulação primitiva, passamos para formas semelhantes, mas que remetem a outra lógica que é a de acumulação do espaço, e esta se faz pela via da expropriação como continuidade do movimento primordial da separação, pois a própria condição para que o capital se realize na atualidade requer a re-integração, re-definida de processos que articulem trabalho morto e trabalho vivo, capital produtivo e capital improdutivo. Reavivar a condição do capital de acumular, mesmo que essa acumulação seja em si a própria crise, capital sem substância, reestabelecer a contradição que é o movimento em si, um re-começo que re-quer condições outras definidas no interior da metropolização como expropriação consubstanciada do espaço por parte do Estado como garantia do reestabelecimento dos circuitos da produção e da financeirização; do Estado como o ente que dota o capital de sua capacidade de se acrescentar ao emitir títulos da dívida pública correspondentes aos financiamentos das novas condições da urbanização, como são os muitos Parques Lineares projetados para a metrópole de São Paulo ${ }^{39}$. Estado, que pela forma jurídica que the é atribuída enquanto poder regulador, garante as formas de expropriação e dispõe o espaço como centralidade das novas condições de financeirização a partir das definições jurídicas postas pelo planejamento e, fundamentalmente, de como tais formas recaem sobre populações que são expropriadas de seu cotidiano, de suas condições de existência, de seus vínculos, de seu lugar.

\footnotetext{
${ }^{39}$ Os dois casos mais emblemáticos são, por suas dimensões quantitativas e qualitativas, o Parque Várzea do Tietê (ao qual se refere esta pesquisa); e o Parque Linear Água Espraiada, no entorno da Avenida Roberto Marinho, também com $60 \mathrm{~km}$ de extensão e que implica a desapropriação de 4000 famílias, a maioria populações de favelas que ocupam terras públicas ou tornadas públicas por decretos. Ver site http://www.prefeitura.sp.gov.br/cidade/secretarias/infraestrutura/sp obras/operacoes urbanas/a gua espraiada/index.php? $\mathrm{p}=167263$. Acesso em 12/2014
} 
Desfaz-se a práxis espaço-tempo-lugar, pois o espaço se transforma em fiduciário, este que se apresenta a partir de sua existência física como existência fictícia, como não-propriedade, contraposta à existência fictícia enquanto existência física da propriedade como expropriação. 


\section{Capítulo IV}

\section{A Relação Capital-Espaço em Relação à Propriedade-Expropriação}

A acumulação de espaço pressuposta a partir da metropolização como produção desigual do espaço se realiza em momentos diferenciados. A acumulação do espaço é uma presença, pois é latente, e é também ausência, pois a expropriação se objetiva quando simultaneamente as condições da financeirização e do planejamento estatal se coadunam. No caso do Pantanal, mais uma manifestação dessa simultaneidade é o ambiente fluvial das várzeas. O plano subjetivo da acumulação do espaço nestes e por estes momentos particulares, se objetiva como expropriação. O espaço torna-se fiduciário, uma reserva territorial que é também um capital possível. É então a acumulação do espaço latente e adormecida enquanto continente da moradia precária sob as condições particulares do processo histórico em São Paulo, conduzido pelas condições da acumulação capitalista que dessa maneira produziram a moradia precária em condições infraurbanas; e ilegal, pelas formas jurídicas postas e opostas na qualificação das moradias em relação aos termos jurídicos dominantes.

A constituição de vastas áreas na metrópole ausentes das condições jurídicas formais formam reservas territoriais às quais se definem a partir do reordenamento político proposto pelo planejamento urbano. Não é possível (re)definir as primordiais relações capital-espaço na reprodução ampliada do capital sem, no entanto, predispor a dissolução do cotidiano dos moradores onde tais condições se desenvolvem, ou seja, existe uma lógica que amarra toda a formação anterior da metrópole à prática contemporânea da expropriação como processo imanente da relação capital-espaço na formação histórica do capitalismo, agora disposta sob novas condições, sob o específico da forma urbana na metrópole de São Paulo. Esse processo histórico nos permite analisar o caso do Pantanal da Zona Leste.

Nesses espaços da metrópole que acumulam a precarização e a ilegalidade é que se desenvolve o cotidiano espoliado. Nos trabalhos de Lucio 
Kowarick $^{40}$ se apresenta a espoliação urbana a partir da apropriação privada do trabalho pela propriedade, o trabalhador não participa, não usufrui de seu trabalho. Na leitura de seus textos percebe-se que a espoliação urbana acontece não somente na expropriação do tempo de trabalho, mas que este processo recria as próprias formas urbanas e se define no cotidiano das populações empobrecidas, no viver um urbano espoliado, para além do processo produtivo em si. Perpassa o vivido, a esfera pública e privada do individuo na sua sociabilidade como reprodução da força de trabalho, como cotidiano espoliado nos longos trajetos, nas parcas condições da reprodução, na economia evanescente. Há um espaço acumulado e ao mesmo tempo usado e assentado por grupos sociais em meio a um cotidiano espoliado. Daí a condição antitética da metrópole, pois afirma o urbano enquanto cotidiano espoliado e o nega a partir da expropriação quando dos momentos requeridos pela reprodução em geral.

Pensarmos nessas condições primordiais para a acumulação do espaço significa pensamos também na existência física do próprio espaço como particular a este processo. David Harvey traz significativas reflexões para se relacionar o espaço ao atual movimento da reprodução do capital através do que ele denomina de "acumulação por espoliação"41 (HARVEY, 2004) que se realiza na despossessão do espaço como condição para inversões de capitais ociosos pela via dos investimentos em novas realizações deste espaço enquanto forma (podem ser as comumente denominadas revitalizações e tantas outras). A construção desse pensamento parte das relações que implicam determinadas condições do espaço como propícias à reprodução do capital, à transformação de parcelas do solo urbano em ativos financeiros:

Tal como no caso da oferta de trabalho, o capitalismo sempre precisa de um fundo de ativos fora de si mesmo para enfrentar e contornar pressões de sobreacumulação. Se esses ativos, como a terra nua ou novas fontes de matérias-primas, não estiverem à mão, o capitalismo tem de produzi-los de alguma maneira. (HARVEY, 2004 p.119).

\footnotetext{
40 Ver KOWARICK, L. 1993; 1994, op. Cit.

${ }^{41}$ Harvey (2004, op. Cit.) reconhece nesse processo algo semelhante à acumulação primitiva, mas que necessita ser retrabalhada para se definir nos atuais processos de produção do espaço. É pela via da espoliação que as possibilidades de investimento se realizam contemporaneamente no e pelo espaço. O autor analisa também outras formas de espoliação, como foi o caso das privatizações.
} 
A relação capital-espaço como uma das formas da reprodução capitalista contemporânea se afirma e se converte na expropriação. A nova forma pressupõe a financeirização, os investimentos que se realizam no e pelo espaço. A produção desigual do espaço é o que possibilita as intervenções no sentido da expropriação.

Essa produção desigual também se fragmenta no espaço, mantem áreas desiguais dentro de uma mesma região. O aprofundamento das desigualdades perpassa uma produção assentada nas relações sociais, ou seja, é uma desigualdade produzida. Para o caso do Pantanal, tal situação é produzida nos diferentes lugares que se inserem dentro e fora dos limites institucionais implementados a partir das legislações restritivas. $\mathrm{O}$ acesso a certos bens funciona como mecanismo de pressão sobre os moradores. Embora situado nos territórios empobrecidos da metrópole, acabam por internalizar formas específicas daquilo que Rosa Tello Robira denomina "territórios de escassez produzida" (ROBIRA, 2005 p. 17). Pensamos que a condição do Pantanal, assim como de vastas áreas na metrópole de São Paulo, como espaço de reprodução do capital se aproxima daquilo que esta autora denomina de "territórios-reserva", ou seja:

[...] territórios capazes de manter em seu interior territórios "não capitalistas" que, na forma de "reservas", tenham a função de resolver de maneira eficaz as sucessivas crises de expansão/acumulação do próprio sistema territorial metropolitano (Idem, p.10).

É necessário considerar que a condição primordial da reprodução enquanto relação capital-espaço se define pela existência de territórios diferenciados no interior da metrópole, aquilo que ao longo de minhas considerações chamei de produção desigual do espaço, mas não que essa diferenciação se situe numa relação entre um território capitalista e outro nãocapitalista, e sim pela existência em si de uma diferenciação interna ao espaço mesmo, fragmentado como conteúdos das contradições postas pela própria reprodução. São espaços empobrecidos relacionados à reprodução da população precarizada pelo trabalho, que vive um cotidiano espoliado e, por essa mesma condição, é juridicamente destituída dos pressupostos da moradia "legalizada", formalizada junto aos órgãos jurídicos, estes que detêm e dispõem da forma reconhecida social e juridicamente da propriedade privada. Tal 
reconhecimento cria e recria olhares sobre essa população e seus lugares na metrópole, algo que se acrescenta à lógica da expropriação. Em meio à representação formal da propriedade da terra, tais contingentes se apresentam dela destituídos pois que diante da leitura formal da sociedade, representam algo "anti-natural":

Os espaços marginais, nesse contexto, não merecem esse qualificativo porque se localizam nos limites ou nas margens do tecido urbano ou porque são espaços residuais ou reduzidos, mas porque, independentemente de seu tamanho e localização, são espaços, do ponto de vista urbano e social, não-regulares, nos quais as "condições naturais" da vida são "infranaturais", ou estão aquém do que (uma sociedade concreta) pode considerar "normal". Os espaços marginais constituem os territórios-reserva onde se produz a acumulação de escassez (Idem, p. 17, o parêntesis é meu)

Impossível vivermos fora de uma sociedade concreta. É esta mesma sociedade que assume tais representações formais do espaço e da propriedade. Aliás, tratam esta ultima como direito sagrado e tratam também de não reconhecer os que se situam fora dela. É importante refletir sobre essa forma propriedade, que aparece sob diversas camadas ${ }^{42}$, definidas por contextos sociais respaldadas por formalizações jurídicas e protegidas pela força policial que cabe ao Estado. Dizemos que ela aparece pois se trata das múltiplas facetas do que é a propriedade privada como categoria primordial e constituída historicamente, anterior ao capitalismo mesmo, mas que neste e por este movimento histórico se consolidou de maneira a se apresentar pela via da separação. Mais do que isso, adquiriu nesse processo dimensões abstratas relativas à equivalência e à identidade, a tautologia para a qual nos chama a atenção Ricardo Baitz:

Se retornarmos nossos olhares à propriedade, em especial a territorial, esta seria representada em sua forma tautológica, pela equação inaugural $\mathrm{P}=\mathrm{P}$, ou Propriedade $=$ Propriedade, 0 que permite esvaziar os conteúdos espaciais e trabalhar abstratamente o continente, o território [...] que faz sentido no âmbito formal, aquele pelo qual o Direito se enveredou (BAITZ, 2007 p. 92)

Mas o movimento tautológico da propriedade equivale ao processo histórico diante do qual se desenvolvem suas aparências. De tal maneira que nos situamos no urbano, e que este se move pelas contradições imanentes e

\footnotetext{
${ }^{42}$ Sobre as "camadas" ver Tese de Doutorado de Ricardo BAITZ, 2012 (op. Cit.).
} 
metamorfoseia as relações socioespaciais, a propriedade em si mesma. Dessa maneira, "além de lógico, este processo é concreto, na medida em que tende, em meio aos diversos agentes sociais, à interferência no real” (Idem, p. 93). O Estado e sua regulação política do espaço rearranja territorialmente a própria configuração do espaço e dessa maneira redefine usos e busca romper limites da apropriação privada, da mesma maneira que repõe os termos da propriedade:

[...] exercendo o poder de normatizar o território, o poder público pôs no espaço sua razão, dividindo a cidade em múltiplos usos [...] a produção do zoneamento foi também a produção de uma raridade, cada vez mais aprofundada, nas áreas urbanas (Idem, p. 94).

De tal maneira o conjunto da metrópole se desenvolve qualitativamente ao definir não somente o lugar dos grupos sociais neste processo, mas de definir também conteúdos para o espaço que tais grupos habitam. Nesse movimento, a tendência das populações empobrecidas foi a posse da terra, apropriar-se privadamente de porções do espaço para a constituição da moradia sem a condição jurídica pressuposta pelo título de propriedade. Ao longo de muitos anos, tal processo se desenvolveu sem que a terra fosse desapropriada. Décadas e gerações se sucederam nos espaços empobrecidos da metrópole. No Pantanal da Zona Leste há pelo menos quatro décadas para certos lugares. Soa quase nada dizer que a ausência do título de propriedade é a condição primordial para a expropriação, uma vez que a metrópole paulistana está assentada grandemente sobre tal condição. Na lógica do Direito, sequer pode-se dizer tal coisa, pois é o título que garante a propriedade. Mas nossa proposição é mais interna, se desloca da aparência da propriedade privada para o seu conteúdo, ao afirmamos que é no interior desta que se situa a compreensão da expropriação, pois, sutilmente, aparece a posse distinta propriedade, mas aquela se situa no interior desta, da qual deriva e para a qual recorre diante da necessidade de romper os limites da reprodução.

Muitas vezes a posse é apresentada como uma oposição à propriedade, embora ela possa ser, no máximo, seu reflexo invertido. A constatação ou persistência da posse evidencia a presença/ausência da propriedade [...] (Idem, p. 97).

Pensar a propriedade não como forma, pois esta escapa-nos de seus conteúdos, uma vez que se torna aparência sob o manto da condição jurídica 
de sua existência, tal qual nos aparece o título de propriedade, a porção definida, delimitada da superfície terrestre. A propriedade aqui tem um conteúdo categorial, ou seja, não é a sua forma que nos interessa, mas sua condição histórica enquanto categoria do capital, pois nesta se apresenta a propriedade transfigurada em terra pública, em posse, em condições outras que nos permitem revelar sua potência enquanto fundamento da separação. $A$ dificuldade em enxergar a propriedade como categoria, pegá-la com as mãos, pois nos aparece como forma social e socialmente reconhecida, jurídica, mercadológica, se manifesta como delimitação privada, terra pública, posse, mas que, para além de sua existência material, pedaço da superfície terrestre, há sua existência abstrato-concreta como categoria histórica.

Falamos da condição antitética da metrópole, a qual, neste momento, requer espaço com intuito de reproduzir capital e dessa forma busca justamente os espaços possíveis e necessários à metropolização. Lembramos que não é mais a urbanização explicada pela industrialização, e sim pela própria condição do espaço urbano como negócio, pela relação capital-espaço. Para Paulo Cesar Xavier Pereira, trata-se de uma "reestruturação imobiliária", que se define no âmbito não somente de uma perda do significado industrial para a urbanização, mas também de outros processos que relacionam a cidade, no caso São Paulo (mas que pode ser também a América Latina), com as condições globais do fluxo de capitais e sua financeirização como negócios imobiliários. Nas palavras do autor:

Mas, o que sintetiza a noção de reestruturação imobiliária? Primeiro, é uma percepção da mudança urbana a partir da dinâmica imobiliária abrangendo um entendimento da especificidade das formas de propriedade, que se funda na valorização imobiliária local mas que se associa à dimensão global da acumulação pela noção de reestruturação. Segundo, é um imbricamento da dimensão social e da dimensão espacial gerando uma unidade onde se observa o filtro da dinâmica imobiliária e a hierarquia das formas de produção do espaço que toma relevo nos processos sócio-espaciais da atual relação espaço-tempo. Por último, a reestruturação imobiliária encontra especificidade num particular movimento de valorização do capital e da propriedade imobiliária, que tende a funcionar e existir como capital, porque esta propriedade associa o financeiro e a indústria oferece uma sobrevida ao capital, capaz de diferenciar e particularizar sua acumulação com relação ao conjunto das outras reestruturações capitalistas. Assim, é uma maneira de falar sobre a atual transformação metropolitana onde se articulam o local e global, 
o espacial e o social, dando conta simultaneamente do que seria mais específico e mais abrangente que afeta a produção do espaço e a distribuição territorial dos grupos sociais (PEREIRA, P. C. X., 2005 p. 3).

Dessa maneira, o espaço da metrópole é analisado como conjunto e ao mesmo tempo como fragmentos, predisposto como um todo aos investimentos imobiliários, mas que fragmentam e hierarquizam os lugares, os quais se relacionam às condições de habitação de grupos sociais e dão margem às inúmeras reintegrações de posse que ocorrem nos últimos tempos, fruto da possibilidade criada para a remuneração dos investimentos imobiliários, a "sobrevida ao capital" da qual nos fala este autor. É também um processo socioespacial, uma vez que reestrutura os lugares, desfaz e refaz as moradias e redefine os grupos sociais, pois:

[...] inovam as condições da apropriação e produção do espaço metropolitano em processos de valorização imobiliária, em que aqueles artefatos, simultaneamente, esvaziam e criam centralidades, redefinem o uso, alteram a ocupação (idem, $\mathrm{p}$. $6)$.

Todo este processo compreendido no interior da própria metropolização de São Paulo se re-significa pela força da reprodução ampliada do capital mundializado. Foi a metropolização como necessidade de acumulação e extração de mais-valia que produziu em seu interior espaços empobrecidos, cuja lógica jurídica, esta também produto das relações sociais de produção, os definiu como ilegais, irregulares, ou seja, potenciais, espaços acumulados propícios às formas de expropriação que, na contemporaneidade, passam a operar pela lógica da reprodução capital-espaço.

Por outro lado, o Estado, a legislação e a propriedade privada do solo urbano formam um conjunto que define não somente a segregação socioespacial, mas também de que maneira tal condição pode ser reintegrada ao processo de exploração capitalista do solo urbano, justamente na forma das reintegrações de posse de terras, sejam elas públicas ou privadas. Mais do que definir uma ausência de políticas de moradia, sempre conclamadas nessa problemática, o que se dispõe é um processo socioespacial carregado dos significados modernos da propriedade privada do solo urbano, cuja leitura se situa no âmbito da economia política do espaço. Tais conflitos expõem as contradições internas da propriedade e sua realização na metrópole capitalista 
contemporânea. Trazem à tona a problemática do espaço como condição da realização do capital na atualidade.

Ao longo da metropolização de São Paulo se constituíram os espaços empobrecidos cujas populações ali assentadas realizavam as formas elementares da acumulação capitalista ao se reproduzirem como populações empobrecidas perfeitamente incluídas nas formas da reprodução. As ocupações de terrenos "vazios" em sua maioria institucionais, definidos por perímetros instituídos há décadas (a legislação proibitiva à ocupação da várzea do Tietê remonta à década de 1960), difundiam como forma comum de moradia os espaços empobrecidos e, ao mesmo tempo, "juridicamente ilegais". Acontece que a posse desses terrenos por parte dessas populações desde sempre confronta-se à propriedade privada da terra como propriedade em si, que em seu interior carrega as diferentes formas sociais desenvolvidas mesmo que thes falte a realização formal posta socialmente. A posse resguarda a propriedade pela via da institucionalização.

Por um lado se integram a mobilidade das populações empobrecidas na metrópole sob a condição política-jurídica da propriedade privada do solo urbano. Tomam posse de áreas "vazias", esvaziadas de conteúdo pela forma propriedade que pressupõe sua representação formal enquanto determinação política e jurídica diante do primordial, o "habitar" (LEFEBVRE, 2004). Fato que explicita esse conflito são as sucessivas reintegrações de posse decretadas pelo poder político nos últimos anos. Aliado a isso, há a condição do espaço como reserva de riqueza, ou seja, a possibilidade de acréscimo no preço da terra pela projeção de investimentos em determinadas áreas da metrópole que passam a movimentar os processos jurídicos de desocupação e reintegração de posse de áreas há muitos anos "congeladas" por seus proprietários. Nos últimos anos, dadas as condições de alto preço dos imóveis e da inserção cada vez maior da terra nos negócios financeiros, tais dispositivos jurídicos são acionados com frequência. Chama a atenção, ao mesmo tempo em que revela essa nova condição do espaço, que a justiça define a reintegração de posse mesmo para terras onde a lei de usucapião já poderia ser colocada como garantia para as populações que ali habitam. A maior parte dos noticiários mostram terrenos ocupados há mais de cinco anos (tempo previsto na lei de usucapião). Em junho de 2013, na Zona Leste de São Paulo, em São Mateus, 
um terreno cujas primeiras famílias lá se instalaram há quase trinta anos teve sua reintegração de posse decretada. Outro caso emblemático, ocorrido em 2012 é Pinheirinho, no município de São José dos Campos, onde cinco mil famílias que ali se assentaram há vários anos foram despejadas por um "exército" de policiais, uma verdadeira operação de guerra com requintes de violência exibidos por diversos meios de comunicação no país, além daqueles que ficaram ocultos e que são a verdadeira face desses violentos processos ${ }^{43}$.

Espaços acumulados, massas de terra reservadas ao processo do capital por longos anos. Definidas no escopo jurídico? Sim e não, pois situadas também numa relação política, aparência daquilo que se define no interior das relações de classe. A classe detentora da propriedade em favor da qual a defesa jurídica toma suas decisões, processo este que se define enquanto relações sociais de produção, pois que determinam as condições de reprodução do capital ao personificar esta classe como elo da ligação ao capital financeiro consubstanciando pela via das relações de classe à objetivação categorial do capital: terra, salário e lucro.

Por outro lado, assim como já mencionada por Ricardo Baitz, Paulo Cesar X. Pereira também entra na questão da raridade do espaço, no entanto, para este há uma estratégia particular de produção da escassez ${ }^{44} \mathrm{e}$, dentre outros fatores, pela inclusão dessa variável, acrescenta-se a valorização. Pensemos o seguinte, a extensão horizontal que a metrópole de São Paulo atingiu é um dos elementos explicativos da raridade pelo ponto de vista de que não há espaço. No entanto, não podemos ver este fenômeno somente desse ponto de vista quantitativo, mas que, no interior do espaço urbano, há um processo qualitativo definidor, que é a propriedade privada em si. Não somente nas bordas da metrópole é que as formas de expropriação ganham sentido,

43 Embora esta pesquisa não apresente dados, o Núcleo de Habitação e Urbanismo da Defensoria Pública do Estado de São Paulo disponibiliza Relatórios nos quais é possível ter uma ideia dessa problemática na metrópole de São Paulo. São inúmeras ações da Defensoria em relação a pedidos na justiça tanto de instituições públicos como privados para reintegração de posse, desocupação de terrenos, desapropriação de áreas, leilões residenciais. A maioria em áreas públicas, quase todas favelas. Boa parte das ações se refere a grandes obras ou propriedades no entorno das mesmas. Ver http://www.defensoria.sp.gov.br/dpesp/Default.aspx?idPagina=2994. Acesso em 01/2015.

44 Ver também "Globalização e Desenvolvimento Imobiliário: tendências de reestruturação" Paulo Cesar Xavier Pereira, disponível em http://www.researchgate.net/publication/265940075 Globalizao e Desenvolvimento Imobilirio tendncias de reestruturao. Acesso 06/2014 
mas nos fragmentos diversos em que a qualidade posta pela propriedade privada possibilita as formas de expropriação, como foi o caso do setor sudoeste da cidade $^{45}$, estudado por vários autores e que incide sobre um fragmento do espaço urbano. Tais processos nos revelam a contradição tornada potente que a propriedade privada estabelecida pressupõe, ou seja, torna-se limite para que ela mesma continue sua expansão, o que resulta em metamorfoses nas formas de uso do solo pressupostas pela legislação ${ }^{46}$.

$\mathrm{Na}$ verdade este fenômeno pode ser compreendido pelas diferentes metamorfoses da propriedade privada nos últimos anos em São Paulo, definidas a partir das possibilidades de romper com os pressupostos da raridade, tal como é, por exemplo, a lei que estabelece o solo criado, possibilidade de expandir os índices de construção de um terreno para além do coeficiente previsto na Lei de Zoneamento, a partir do pagamento por esse a mais $^{47}$. Diversas leis e disciplinamentos do espaço, constituição de perímetros de legislação específica têm garantido nas últimas décadas que a limitação imposta pela raridade do espaço seja sobrepujada. É o que Paulo C. X. Pereira chama de "desabsolutização" da propriedade (PEREIRA, 2005, op. Cit.).

Tal problemática de uma raridade torna-se mais contundente diante das variadas formas com que os limites à produção do espaço se apresentam contemporaneamente, contradições da própria produção do espaço. Tal é o caso das compensações ambientais, presentes nos projetos apresentados junto aos órgãos financiadores internacionais, como é o caso do Banco Interamericano de Desenvolvimento (BID). Tais financiamentos se realizam a partir da existência física de áreas que possam "compensar" intervenções em outras áreas. Daí a necessidade de organizar no espaço da metrópole áreas institucionais capazes de romper com os limites da suposta raridade do espaço em suas variadas formas, como é o caso das compensações ambientais. Pensar essa relação capital-espaço significa retomar a contradição intrínseca da propriedade privada, e não que esta necessita ser redefinida por termos quantitativos. Como nos lembra Ana F. A. Carlos:

45 Ver FIX, M., 2001 op. Cit.; CARLOS, A. F. A. 2001, op. Cit.; FRUGOLI JR, Heitor: Centralidade em São Paulo. São Paulo: Edusp, 2000.

${ }^{46}$ Tese defendida por Ana Fani Alessandri Carlos in CARLOS, 2001, op. Cit.

${ }^{47}$ Mais uma vez a Tese de Ricardo BAITZ (2012) é referência para este debate. 
Nesse momento, o espaço, produto da reprodução da sociedade, entra em contradição com as necessidades do desenvolvimento do próprio capital. Isso significa que a raridade é produto do próprio processo de produção do espaço, ao mesmo tempo que sua limitação (CARLOS, 2001 p.22).

Mas essa raridade precisa ser vista no âmbito qualitativo a partir de outros conteúdos internos da propriedade privada. Existe de fato uma raridade do espaço, ou uma redefinição qualitativa da propriedade privada que aparece pela via da institucionalização como forma quantitativa? A análise deste processo se situa no interior da propriedade privada, em suas contradições enquanto categoria primordial da modernidade, processo histórico no qual suas metamorfoses repõem as condições de sua realização e fragmentam a raridade do espaço.

Aqui a produção desigual do espaço pressupõe que a condição de expansão do capital pelo espaço se sustente a partir da forma propriedade, em que a posse é a propriedade em si, e por esta condição a propriedade subsumi a posse, como é o caso do Pantanal da Zona Leste. Dito de outro modo, há ainda muito espaço na metrópole de São Paulo, predisposto como posse, sem título de propriedade e que, confrontado à ordem jurídica imposta pela propriedade, no interior desta, se desfaz. É a expropriação de suas populações empobrecidas em vastos territórios que repõe os termos da produção do espaço. Este processo dinamiza, inclusive, a propriedade jurídica como tal, já que uma parcela desta população expropriada, como é o caso de muitas famílias no Pantanal da Zona Leste incluídas nos programas populares de acesso à moradia pela via da legalidade, com financiamentos públicos e endividamento particular para alcançar a propriedade de fato e de direito.

Tal condição é histórica e se apresenta na metropolização de São Paulo como intrínseca a esta, como produto das relações sociais de produção que propiciaram formas de acumulação baseadas na extração de mais-valia, num regime de exploração de trabalho que marcou o cotidiano desses trabalhadores e constituiu o seu espaço de moradia como resultado e ao mesmo tempo processo dessa exploração. No interior deste processo, uma acumulação de espaço se anuncia, mas repousa, adormecida, no aguardo de situações propícias. Marcou, portanto, o espaço da metrópole como diferenciado internamente, cunhado por inúmeros autores como centro-periferia. Nosso 
intento é não separá-los, pois estão integrados pelo processo em si, são resultado, mas, mais do que isso, são também movimento expresso pelas relações sociais de produção. Nosso entendimento é de que, neste momento de contradições tão latentes entre as forças produtivas e as relações de produção, momento em que a reprodução se apresenta como crise, tem-se a reestruturação das relações entre categorias primordiais da reprodução. Se apresentam formas históricas que se assemelham a momentos anteriores, tais como aqueles da acumulação primitiva, mas sob novas formulações para a expropriação. Por essa acumulação de espaço, realizada pela desigual produção social no espaço, a reprodução contemporânea forja a expropriação no próprio espaço. A condição de sua realização perpassa diversos processos, mas se fundamenta na forma Propriedade como categoria central, ao mover-se em meio aos espaços que a própria metropolização constituiu, no sentido de re-integrá-los sob novas condições postas pela contemporaneidade das formas de reprodução que relacionam capital e espaço. Nada mais sutil e ao mesmo tempo profundo que a própria terminologia usada pelas instituições, desfazimento: se desfaz um processo, esse do lugar da reprodução da moradia dos pobres, para se fazer outro, que desfaz como expropriação o lugar da moradia dos pobres na metrópole.

Nesse momento histórico em que o processo produtivo redefine seus patamares de acumulação e se direciona para a relação capital-espaço, a forma Propriedade permanece com seus conteúdos, não somente jurídicos e institucionais, mas aqueles que realizam as formas da reprodução ao possibilitar o acréscimo de juros como pressupostos dos adiantamentos creditícios pela financeirização em suas variadas formas. A qualidade de porções da superfície terrestre em representarem, a partir da propriedade, valores produzidos socialmente pelo trabalho soa, como diz Marx, como algo místico. Embora apareçam como processos distintos, a Propriedade predispõe aos seus proprietários a repartição da mais-valia nas esferas da renda e dos juros, oriundos da propriedade da terra e do dinheiro ${ }^{48}$. Em ambas as situações, propriedade do dinheiro e da terra possibilitam captar parcelas da

\footnotetext{
${ }^{48}$ Marx faz uma consideração irônica no capitulo XLVIII (A Fórmula Trinitária) dada essa aparência da repartição da mais-valia em juros, renda e salário: "relacionam-se mais ou menos como custas de cartório, beterrabas e música” (Marx, 1991 p.936).
} 
mais-valia social justamente por se tornarem fundamentos da produção, ou seja, funcionam nesse processo como capital, empréstimos para realizar a produção da mercadoria espaço, sempre a partir de relações de exploração, da força de trabalho, da terra. Tais rendas aparecem como separadas, independentes, mas a trama que lhes une é o capital em si como relação social de exploração, de apropriação privada de parcelas do trabalho social justamente porque a propriedade como separação se defronta com o trabalho e subtrai deste a substância que move o processo, o valor que possibilita ao capital se reproduzir como valorização. Para o nosso caso, ambas as categorias se amarram, terra e juro, pois é o espaço como condição da financeirização que permite uma parcela da reprodução do capital em geral.

Para Marx, a "moderna forma da propriedade fundiária" (MARX, 1991 p. 706), pressupõe condições históricas que destituem, separam mesmo o trabalho da terra no modo capitalista de produção e permitem ao proprietário fundiário não somente "dispor de determinadas porções do globo terrestre como esferas privadas" (ibidem), mas que estas parcelas pressupõem também a "valorização desse monopólio na base da produção capitalista" (ibidem). A maneira pela qual se exerce essa valorização se dá pelo uso da terra privada e pelo pagamento por parte de quem a usa ao "consentimento de empregar seu capital nesse campo especial (a terra) de produção" (idem, p. 710). Vejamos que Marx trata por capital, ou seja, que o emprego da terra no processo produtivo seja capaz de subtrair do trabalho sua porção determinada de maisvalia, que a parte que cabe ao proprietário seja oriunda do fracionamento da mais-valia produzida pela relação trabalho-propriedade como separação. Aqui a propriedade se desdobra em terra e outros meios de produção (ferramentas, por exemplo), assim como a mais-valia se fraciona entre os proprietários da terra e os desses meios respectivamente.

Portanto, ao definir que "renda fundiária é a forma em que se realiza economicamente, se valoriza a propriedade fundiária" (ibidem), Marx nos aponta a mais-valia como estrutural na valorização. Por outro lado, há considerações a partir de outras formas de acréscimo ao preço da terra como renda, mas que não integram a renda fundiária propriamente. Tais condições acontecem por "capital incorporado à terra" (ibidem), que o autor trata por capital fixo, mas que este, como "acidente inseparável da substância" (idem, p. 
711) se realiza como "juro pelo capital empregado na terra e pelas melhorias que ela assim adquire como instrumento de produção pode integrar a renda" [...] "mas que não faz parte da renda fundiária" (ibidem). Dessa forma "o proprietário acrescenta à renda fundiária propriamente dita o juro pelo capital incorporado à terra" (ibidem).

O desenvolvimento das forças produtivas como processo que se objetiva no espaço dispõe aos proprietários acrescer os valores de suas propriedades:

[...] se abstrairmos do movimento da renda fundiária propriamente dita - do enriquecimento ascendente dos proprietários de terras, do aumento contínuo de suas rendas e do valor monetário crescente de suas propriedades com o progresso do desenvolvimento econômico (ibidem).

Daí que a renda é um processo social que se define no campo das relações sociais de produção como expressão concreta do movimento da reprodução capitalista e como condição socioespacial. O raciocínio de Marx a respeito da condição da renda fundiária como "existência pura, sem qualquer acréscimo de capital incorporado ao solo" (idem, p. 714) soa como uma "categoria que à primeira vista se revela irracional" (idem, p. 715), pois em si a "terra não é produto do trabalho" (ibidem), mas "atrás dessa forma irracional oculta-se uma relação real de produção" (ibidem), o que se explica no campo da capitalização posta pela mercantilização da terra derivada dos processos sociais, referenciada "pelo movimento do preço da terra independente do movimento da própria renda fundiária, regulado apenas pela taxa de juro" (ibidem). Disso resulta que:

[...] o preço da terra tende a subir, independente mesmo do movimento da renda fundiária e do preço dos produtos agrícolas, do qual a renda constitui parte (idem, p.716). $\mathrm{Na}$ prática, constitui o rendimento do proprietário da terra, valorização econômica de seu monopólio, do mesmo modo que a verdadeira renda fundiária, e como esta, atua no preço da terra determinando-o (idem, p. 717).

A renda fundiária é, portanto, um processo histórico e social, pressuposto por uma condição que não se explica exclusivamente pela produção na terra de per si, mas pela existência desta como monopólio privado, o que a torna estrutural no processo que Marx denomina "espoliação contínua" (MARX, 1989 p. 152), ou seja, que a propriedade separada do trabalho permite aos proprietários expropriar o trabalho, "a renda resulta das 
relações sociais nas quais se realiza a exploração" (ibidem). Constitui-se como um valor social, pois seus produtos são mercadorias se e somente se confrontados às mercadorias em geral produzidas tanto no meio rural como no urbano. Neste último o mercado de terras se apresenta pelo confronto dos lugares, uma vez que a mercadoria se constitui da terra em si, mas que esta se valoriza no processo social acrescida do trabalho social que the proporciona maior valor e se expressa no aumento do preço desta mercadoria. Tal condição só foi possível pelo fato de que no desenvolvimento histórico do capitalismo a propriedade separada do trabalho se defronta com este materializado sobre aquela de maneira a representá-lo na equivalência geral da mercadoria terra, acrescida do trabalho social, definida então como equivalente deste mesmo trabalho por sua expressão abstrata de preço no mercado de terras em geral.

De qualquer maneira, o que se observa é a terra como relação social que equivale ao processo histórico em movimento, que propugna a terra como expressão da natureza, ao mesmo tempo em que essa mesma natureza se explica no processo de abstração social:

A renda, em vez de ligar o homem à natureza, apenas liga a
exploração da terra à concorrência [...] como renda a
propriedade fundiária é mobilizada e se torna um objeto de
comércio [...] Quanto ao arrendatário, ao capitalista industrial,
ao operário agrícola, eles não estão mais ligados à propriedade
que exploram do que o empresário e o operário manufatureiro
ao algodão ou à lã que fabricam; só experimentam vinculação
ao preço de sua exploração, ao produto monetário (idem, p.
148).

Daí que a complexidade do processo social hoje põe e dispõe a terra como um equivalente geral diante da produção social global ao mesmo tempo em que relaciona um processo específico que se realiza nos e pelos lugares como fragmentação predisposta por esta mesma produção ao dispor tais fragmentos à realização geral da reprodução capitalista. Em meio às metamorfoses do processo produtivo global, torna-se o espaço não somente um meio, porque é histórico, nem também um fim, pois se combina ao processo produtivo na condição da exploração do trabalho, mas uma categoria primordial, um processo em si ao repor os termos da reprodução na relação com a propriedade privada da terra, relação essa que se constitui enquanto um poder sobre essa parcela, um poder de dispor dela para si e indispô-la aos 
outros, assim como dispor das condições históricas e sociais enquanto objetivação socioespacial como tributo social que lhe cabe neste processo.

"E o poder imenso que deriva dessa propriedade fundiária [...] capacita este (proprietário) a impedir praticamente de residirem neste ([a] parcela do) planeta os trabalhadores (ou outros) [...] Parte da sociedade exige da outra um tributo pelo direito de habitar a terra [...] Concorrem para elevar necessariamente a renda fundiária relativa as construções, 0 aumento da população, a necessidade crescente de habitações daí resultante e o desenvolvimento do capital fixo, que se incorpora à terra ou nela lança raízes ou sobre ela repousa, como todos os edifícios industriais, ferrovias, armazéns, estabelecimentos fabris, docas, etc. Aí não é possível reduzir o aluguel, que representa juro e amortização do capital empregado na construção, à renda correspondente apenas ao terreno [...] o espaço como necessário à toda produção e a toda atividade humana. E a propriedade fundiária cobra seu tributo nos dois domínios. A procura de terrenos para construir aumenta o valor do solo na função de espaço e de base" (MARX, 1991 p.890).

É, pois a terra, suas inúmeras frações, uma representação abstrata do processo social ao tornar-se equivalente monetário deste mesmo processo e dessa forma representá-lo em diferentes situações, pois acompanha tanto 0 desenvolvimento socioespacial nela objetivado, capital fixo se se pode dizer assim, como o próprio movimento especulativo predisposto pela mercantilização que inclui o processo financeiro, a movimentação dos títulos, do câmbio, de toda a sorte de papéis que se equivalem ao dispor para seus proprietários uma referência monetária.

Poderia parecer "irracional" o surgimento de um "plus" como juro pago ao financiamento predisposto para a construção do Parque Várzea do Tietê. Aos envolvidos no contrato, os termos jurídicos que dispõem prestamista e mutuário, aparece a ajuda que ambos trocam ao possibilitar um adiantamento financeiro com pressupostos de resolução de problemas ao objetivar formas de lazer e "qualidade de vida" preservando os atributos ambientais, aumentando a quantidade de verde por habitante, diminuindo as inundações (o que não é verdade) removendo as populações para apartamentos não quitados longe das inundações (e de suas referências socioespaciais também). No entanto, tratase de confrontar a terra enquanto título de dívida ao relacioná-la no movimento financeiro como fundos de investimento por meio dos financiamentos aos projetos tanto públicos como privados promovidos por agências que controlam uma parte dessa massa financeira global, como é o caso do Banco 
Interamericano de Desenvolvimento, que financia parte da construção do Parque Várzea do Tietê.

Por um lado, podemos pensar que a reprodução na contemporaneidade da produção do espaço é juro pago como realização de investimentos dos capitais ociosos baseados na existência de ativos sociais, como é o caso da terra, disponíveis para tais investimentos, cujo "pagamento", ou melhor, a promessa de, situa-se também e fundamentalmente, na dívida pública. Por outro, há uma complexa trama que expõe diferentes elementos para a análise, uma vez que a financeirização do espaço pela via dos empréstimos por parte das entidades financeiras possivelmente é pura ficção, dinheiro de financiamento tornado dívida pública. Dessa forma, o Estado e o mercado de circulação financeira se relacionam ao proporcionar uma socialização desse endividamento de uma forma puramente abstrata, mas objetivamente inserida no cotidiano social. Pela via do Estado, tais dívidas podem ser diretamente incorporadas aos índices inflacionários, à regulação cambial, à emissão de títulos, ao pagamento de juros, ao superávit primário, enfim, às formas fictícias que permitem a apropriação privada da riqueza social por parte dos investidores. Como nos lembra Flavia E. Martins: "o Estado é o lastro do endividamento, e como lastro é a forma mais segura e eficaz que o capital tem de repassar para o conjunto da sociedade suas perdas" (MARTINS, $2010 \mathrm{p}$. $65)$.

Esse movimento é abstrato e concreto ao mesmo tempo, pois relaciona a ficção da produção de valor sem substância, dinheiro como mais dinheiro, à produção direta da riqueza social e, o que se torna mais comum no momento atual, a espoliação de contingentes populacionais para que este acréscimo à reprodução ocorra; mas para estas populações diretamente envolvidas compete o decréscimo da porção que Ihes cabe da riqueza socialmente produzida. Não é por acaso que em tempos de reprodução cada vez mais definidos pela relação dinheiro que se torna mais dinheiro, as formas de precarização do trabalho se mundializam e se aprofundam como relações concretas. Relativamente a isso, a reprodução social se ficcionaliza profundamente como relações abstratas. A condição abstrato-concreta desses tempos se reproduz como relações sociais. 
Personas de um processo contemporâneo da reprodução capitalista, como são os mandatários das entidades financeiras, suas alianças políticas, tanto com pessoas dos poderes executivos, como do corpo técnico-burocrático do Estado, esses são a representação de classe que se confrontam aos moradores expropriados das áreas destinadas aos inúmeros projetos urbanísticos, como é o caso desta pesquisa, do Parque Várzea do Tietê. Aqueles podem ser imaginados, como nos fala François Chesnais "um administrador praticamente anônimo de um fundo de pensão com ativos de bilhões de dólares, quem personifica o 'novo capitalismo'" (CHESNAIS, 1996 p.15); estes, os moradores expropriados, despidos de sua materialidade exterior, a moradia, assumem-se nus diante do projeto que se lhes defronta, e nus se reconhecem como expropriados, lutam em meio às dificuldades de saber quem são, quem está contra ou a favor deles, se lutam contra si mesmos, com quem e contra o que lutam. Se seu inimigo é o Poder Político obscurecido pelas formas de representação das contradições contemporâneas, tornam-se eles mesmos, como invasores da natureza, complicadores nas infindas problemáticas metropolitanas. Destituí-los de suas condições objetivas, não somente da moradia, mas da necessidade de lutar é a forma obscurecida que thes aparece. Como que num espelho "machadeano" 49 , sua constituição como trabalhadores precários, como indivíduos vivendo um urbano desurbanizado, espoliados das condições materiais que produzem na relação capital-trabalho, aparece-lhes como o outro da metrópole, cidadãos fora da prática social e que necessitam ser "incluídos" nas práticas socioambientais, nas formas reconhecidas socialmente como são a propriedade privada e 0 progresso contemporâneos. A força que move a expropriação contemporânea se constitui nesse processo, tornar as representações do espaço espaços de representação.

\footnotetext{
${ }^{49}$ No conto "O Espelho: Esboço de uma nova Teoria da Alma Humana", Machado de Assis confronta seu personagem, Jacobina, à sua imagem refletida num espelho. $O$ desejo e a satisfação que Ihe trouxeram a designação de "Alferes" quando de seus vinte e quatro anos, ressignificaram a forma deste dantes pobre e desvalido soldado da Guarda Nacional ver-se e ser visto diante de seus iguais na vila em que habitava. Tal representação incrustou-se em seu inconsciente de forma que, anos mais tarde, era essa a imagem que se refletia ao defrontar-se com um espelho, posto em seu quarto por vontade de sua tia Marcolina, como sinal da vaidade dele e por ele. Via-se no espelho o Alferes dos tempos gloriosos, dos admiradores, dos bailes imperiais, a alma exterior: A única parte do cidadão que ficou comigo foi aquela que entendia com o exercício da patente; a outra dispersou-se no ar e no passado (p. 29). Ver Machado de ASSIS: Contos. Rio de Janeiro, Coleção Nossos Clássicos. Livraria AGIR Editora,1977.
} 


\section{Parte 2}

Metropolização 


\section{Capítulo V}

\section{Espaço e Relações Sociais na Metropolização de São Paulo}

Pensar a produção do espaço na contemporaneidade é remeter às formas de reprodução do capital na relação capital-espaço ao longo da metropolização de São Paulo. É pensar nas relações sociais estruturadas sob a modernização enquanto processo que se constituiu a partir do duplo urbanização-industrialização que se deu principalmente de meados do século $\mathrm{XIX}$ em diante e sedimentou as categorias elementares do capital nas relações sociais de produção do espaço de diferentes maneiras, movendo as contradições essenciais do processo urbano sob as condições mundiais da relação crise-acumulação do capital. Mais do que isso, é desvendar o movimento histórico das categorias primordiais do capital e de que maneira transcendem uma localização temporal para se definirem enquanto relações históricas num espaço particular, no processo específico de formação da metrópole de São Paulo. É necessário retomar tal processo na busca por elementos que possam trazer a compreensão tanto das mudanças nas relações sociais de produção nas últimas décadas como dos nexos que permitem compreender a relação capital-espaço como centralidade da reprodução contemporânea.

Essa compreensão pressupõe análises de diversas categorias e seu movimento ao longo da metropolização para compreender a produção desigual do espaço como processo histórico e a acumulação de espaço como resultante desse mesmo processo. A metropolização de São Paulo é um processo ao mesmo tempo geral e particular. Carrega consigo o sentido da mundialização econômica em relações sociais que se desenvolveram sob um ordenamento de classes internamente constituído. Mais ainda, sob as particularidades de um ambiente natural que por vezes implicou os rumos da modernização. A natureza natural torna-se social pela apropriação urbana de seus elementos originários como forças produtivas dessa empreitada homérica de construir a metrópole de São Paulo, não como permanência de um processo, mas como destituição, destruição, expropriação. Caminhar pelas relações sociais e suas 
transformações foi o caminho escolhido para se chegar ao espaço da metrópole.

Disso resulta que se refazem as relações sociais a partir das categorias postas historicamente, como foi o caso do momento em que aconteceu o enraizamento de uma classe dominante urbano-industrial em São Paulo e das necessárias metamorfoses constituídas para que a reprodução caminhasse personificada nessa nova classe e objetivada enquanto relações socioespaciais. Mas, antes mesmo, muito antes, nos primeiros séculos da colonização, quando dos aldeamentos paulistas, aquele espaço puramente rural, talvez até mais natural do que rural, na verdade uma mistura do rural com as relações entre os grupos ameríndios originários, mas que, ao transcender da forma do espaço em sua apresentação objetiva, de sua leitura como paisagem ${ }^{50}$, pode-se revelar a modernidade nas instituições impostas pelo processo colonial oriundo do projeto jesuítico e desvendado a partir das relações sociais. Por exemplo, os jesuítas dos aldeamentos paulistas viam nas formas de sociabilidade indígena elementos estranhos ao processo da modernidade que aqueles vinham impor. Chamava-lhes a atenção 0 desprendimento indígena com relação ao trabalho. Na verdade, não havia para estes o sentido do trabalho como acumulação, elemento primordial da agenda jesuíta, e porque não de todo o processo colonial, o trabalho disciplinado, o excedente da produção, a ponto de Pasquale Petrone ${ }^{51}$ localizar em sua obra o que chamou de "população desajustada" nos aldeamentos, tanto indígenas como mestiços empobrecidos, os quais não se reproduziam dentro da lógica moderna, do trabalho como sentido de acumulação e, primordialmente, como separação. Ou, já mais adiante, nos séculos XIX e XX, na pesquisa de Antonio Candido $^{52}$, que ultrapassa um tempo específico, o da colonização, mas que revela um processo transtemporal, ou seja, que aquele primordial estabelecido durante a colonização permanece como remanescente desse processo original em São Paulo, personificado no caipira, que reproduz em meio à modernização

\footnotetext{
${ }^{50}$ Tal formulação perpassa a análise epistemológica proposta por Milton SANTOS: A Natureza do Espaço. São Paulo: Edusp, 2002 p. 103 a 113. Há outras formulações que não cabem aqui, de cunho mais metodológico e físico, e que podem ser apreciadas na obra, por exemplo, de Gerard BERTRANDT e suas considerações sobre o Geossistema.

${ }^{51}$ Ver Pasquale PETRONE: Os Aldeamentos Paulistas. São Paulo: EDUSP, 1995 p. 133-4.

52 Ver Antonio CANDIDO: Os Parceiros do Rio Bonito. São Paulo, Editora 34, 2001 (1964) p. $111-2$.
} 
aquilo que o autor chamou de "desnecessidade do trabalho", uma espécie de "desajuste" dessa população em relação a uma generalidade imposta, esta que o autor denomina de "economia gera"l. Num dado momento, esta obra localiza e fundamenta a relação dialética rural-urbano primordial para que se entendam as supressões das formas de sociabilidade desses grupos postas pelas relações sociais de produção historicamente constituídas na modernização em São Paulo, uma vez que o rural passa a ser explicado por sua relação negativa com o urbano. Não era mais possível manter-se rural sem se urbanizar e o caipira se suprime diante do outro de si, ainda que se mantivesse no meio rural, mas este já intrincado e explicado nas e pelas relações negativas entre rural e urbano ${ }^{53}$.

Podemos então dizer que São Paulo já nasceu moderna se olharmos para as categorias dessas novas condições de sociabilidade, que se constituem a partir da internalização das relações sociais como relações de produção desde o início da colonização, e não somente para as formas constitutivas de um predominante e arcaico mundo rural. Podemos até afirmar que essa modernização é mundial, que o processo colonial pôs São Paulo na divisão internacional do trabalho, mesmo que esta região não produzisse as mercadorias essenciais durante sua existência colonial, assim como nos anos iniciais do Império, mas de suma importância para a condição socioespacial da empresa colonial ao impor e dispor dos grupos originários e seus descendentes, assim como de suas relações territoriais, para o trabalho socialmente necessário ao próprio sentido da colonização ${ }^{54}$.

Derivam daí as condições para pensarmos nessas formas rurais já definidas pela modernização. $O$ que de fato se consolida mesmo nesse universo puramente rural é que a produção torna-se exterior ao trabalho, separada dele. Esta condição primordial norteia todo o movimento histórico desde os primórdios da colonização aos dias atuais. É o próprio sentido da modernização em si, corresponda ela ao período que for, traz como

\footnotetext{
${ }^{53}$ Idem, p. 283

${ }^{54}$ Caio PRADO JUNIOR (Historia Econômica do Brasil. São Paulo: Brasiliense, 1987 [1945]) aponta a empresa colonial baseada no monopólio português da produção, garantida pelo pacto colonial como o processo estrutural que viabilizou a colonização enquanto regime de acumulação para a Coroa Portuguesa. Dispor dos elementos sócio-territoriais postos pela iniciativa empresarial portuguesa era a forma de garantir tanto excedentes como elementos da produção colonial no Brasil.
} 
pressuposto a destituição do trabalho pela instituição da propriedade privada como relação primordial que constitui as categorias essenciais que põe e opõe as relações sociais como relações de produção:

[...] o objeto que o trabalho produz se the defronta como um poder independente do produtor. O produto do trabalho é o trabalho que se fixou num objeto, fez-se coisal, é a objetivação do trabalho. A efetivação do trabalho é a sua objetivação [...] A exteriorização do trabalhador em seu produto tem o significado não somente de que seu trabalho se torna um objeto, uma existência externa, mas, bem além disso, que se torna uma existência que existe fora dele, independente dele e estranha a ele, tornando-se uma potência autônoma diante dele, que a vida que ele concedeu ao objeto se lhe defronta hostil e estranha (MARX, 2004 p. 80-1).

A separação capital-trabalho e sua necessária relação negativa constituem historicamente as premissas da reprodução das relações sociais de produção. Ao adentrarmos aos meados do século XIX, verificamos as transformações fundamentais postas pelas novas relações urbano-industriais, mas que mantêm-se primordialmente como separação, embora passem a requerer novas condições jurídicas e políticas, tal como foi o movimento de passagem do trabalho escravo para o assalariado, mas não sem antes se transformar, em sua forma jurídica sob os desígnios do Estado, as relações de propriedade da terra (embora a posse da terra já se apresentasse como propriedade, faltavam-Ihe as condições políticas primordiais deste momento), uma vez que a própria relação senhor-escravo era em si uma relação de propriedade:

\begin{abstract}
A lei de Terras (Lei no 601 de 1850) garantiu a mobilização das instituições jurídicas e policiais na defesa da propriedade fundiária, garantindo ao mesmo tempo, o caráter compulsório do trabalho, da venda da força de trabalho ao fazendeiro por parte dos trabalhadores que não dispusessem de outra riqueza senão a sua capacidade de trabalhar [...] Ora, a riqueza da época é principalmente, a terra neste país desprovido então, de grandes capitais. A Lei de Terras consagrava aquilo que não existia plenamente: a terra como equivalente de capital, como renda territorial capitalizada (MARTINS, 2004 p. 146-7).
\end{abstract}

A constituição jurídica da propriedade capitalista da terra acontece sob a condição elementar da separação trabalho-propriedade que já estava posta, mas que se ajustava naquele momento à reestruturação das relações sociais de produção e não somente à condição de elevar a terra a um equivalente de capital. Tratava-se, sobretudo de formalizar as instituições necessárias para 
outras formas de sujeição na relação capital-trabalho, pois que a metamorfose nas relações de trabalho que se constituía naquele momento, a partir da segunda metade do século $\mathrm{XIX}$, de transição do trabalho escravo para 0 assalariado, relacionava-se a um devir urbano-industrial já definido anteriormente e sob as novas relações de produção que incluíam, a partir de então, não mais aquelas postas pelo trabalho escravo, mas estas que se definiam pelo trabalho "livre". A substância desse novo campo de relações se apresenta numa outra condição espacial, o urbano, e fundamentalmente, pelas relações sociais de produção definidas no seio das novas relações de classes oriundas de momentos históricos anteriores, mas que se desenvolviam no interior da própria mudança socioespacial requerida pelo processo:

O burguês já surge no Brasil como uma entidade especializada, seja na figura do agente artesanal inserido na rede de mercantilização da produção interna, seja como negociante. Pela própria dinâmica da economia colonial, as duas florações do burguês permaneceriam sufocadas, enquanto o escravismo, a grande lavoura exportadora e o estatuto colonial estiverem conjugados. A Independência, rompendo o estatuto colonial, criou condições de expansão da "burguesia" e, em particular, de valorização social crescente do "alto comércio". Enquanto o agente artesanal autônomo submergia, em consequência da absorção de suas funções econômicas pelas "casas comerciais importadoras", ou se convertia em assalariado e desaparecia na "plebe urbana", aumentavam o volume e a diferenciação interna do núcleo burguês da típica cidade brasileira do século XIX. Ambos os fenômenos prendem-se ao crescimento do comércio e, de modo característico, à formação de uma rede de serviços inicialmente ligada à organização de um Estado nacional mas, em seguida, fortemente condicionada pelo desenvolvimento urbano (FERNANDES, 2005 (1975) p.34-5).

Em São Paulo esta metamorfose social e espacial desenvolveu-se em meio à combinação de formas rurais e urbanas, mas já definidas pela própria condição da mercadoria rural enquanto objetivação das complexas relações mundializadas da economia naquele momento, predispostas por processos tanto da agricultura, plantio, colheita, trato com a terra, como por relações financeiras, de mercadorias e futuros, de produção tecnológica, de companhias de comércio, de ferroviárias, de imigração. A constituição de uma classe dominante burguesa forjada por um lado nas arcaicas relações sociais 
estruturadas no regime colonial escravista e patrimonialista ${ }^{55}$, e a partir de então, também sob os anseios de um devir urbano-industrial, este mesmo histórico, relacionam diferentes momentos a partir dos quais São Paulo se insere numa economia urbano-industrial de caráter mundial. Ainda que sustentada na produção rural, a do café, tal burguesia passa a se constituir como o outro do rural em si. Mesmo que oriunda de uma economia agroexportadora, e justamente por isso, tal classe se constituía a partir dos elementos estruturais dessa nova economia urbano-industrial, inserida num contexto mundializado, portanto, de certo modo a este atrelado e por este definido: "Como cultura comercial, a do café contribuía para que se formasse uma classe numericamente reduzida, mas econômica e financeiramente onipotente [...] A essa cultura nova, correspondiam novos modos de pensar" (MONBEIG, 1984 p. 97).

Pierre Monbeig (op. Cit.) nos apresenta tal classe diferenciada no interior da própria produção cafeeira a partir de relações mundializadas e que estruturavam novas formas de sociabilidade assim como assentavam novas relações entre as categorias da reprodução do capital, algumas renovadas a partir de momentos anteriores, outras predispostas pelas novas condições surgidas; trabalho livre, mercado financeiro mundial, economia monetária, propriedade privada de fato e de direito, rentismo, sociedades anônimas, enfim. Não eram somente relações econômicas que permeavam a constituição de tais indivíduos, pois estes se estruturavam como classe dominante, cuja necessidade perpassa novas relações políticas e de poder, estruturadas ainda no regime imperial, mas que ganhavam contornos republicanos nos quais se incluíam representantes dessa mesma classe burguesa que, na forma da lei e, sobretudo, do planejamento urbano, regulavam as tensões sociais advindas da relação capital-trabalho em favor de suas condições de reprodução no processo urbano enquanto classe ${ }^{56}$.

${ }^{55}$ A respeito desses elementos constitutivos das classes dominantes no Brasil ver Marilena CHAUÍ: Brasil: Mito Fundador e Sociedade Autoritária. São Paulo: Editora Fundação Perseu Abramo, 2000.

${ }^{56}$ A obra de Pierre MONBEIG (op. Cit.) define os fazendeiros do oeste paulista não como uma oligarquia rural, mas como uma nova classe definida no interior de uma economia mundializada e propriamente urbana. Ver também a obra de José de Souza MARTINS: O Cativeiro da Terra (MARTINS, 2004), que relata o quanto essa nova classe dominante manipulava políticas nacionais em favor de sua estruturação enquanto classe, que resultou em transformações profundas na sociedade brasileira, fundamentalmente o trabalho livre. $O$ trabalho de Zélia 
O Estado como condição da reprodução assegura de diferentes maneiras essa substância das relações sociais de produção, consubstanciadas pelo próprio Estado enquanto Estado Burguês, ou de alguma forma, de representação das condições burguesas como esfera de dominação política pressuposta por relações de classe definidas no interior do movimento histórico. Karl Marx em seu embate com Max Stirner a respeito da formação do individuo, desenvolve a tese da necessidade da construção política de burgueses individuais enquanto classe, constituída historicamente sob a égide do liberalismo político, sobretudo em momentos históricos como foram as revoluções Inglesa e Francesa. Elementos anteriores como o Direito, ele mesmo direito à propriedade, são formações sociais que se articulam no plano do próprio desenvolvimento social como aparência de uma construção individual:

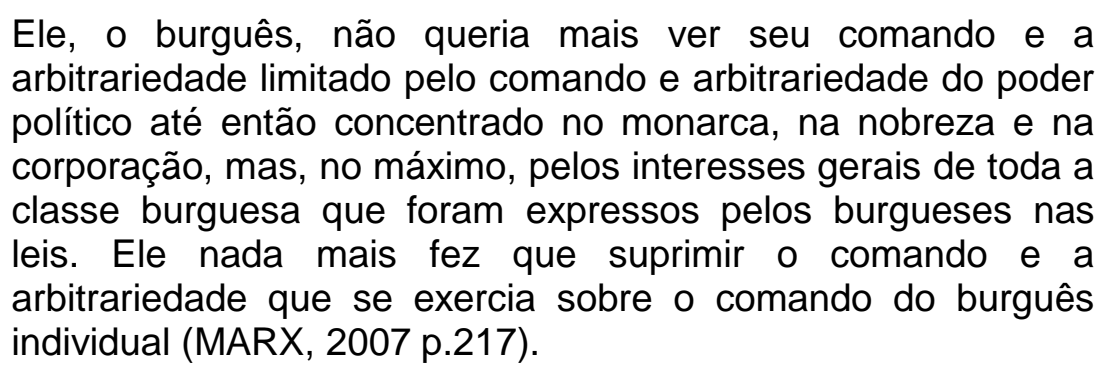

Dito de outro modo, a razão burguesa se expressa na razão de Estado, entidade política e jurídica cujo poder expõe a própria condição de estruturação das relações sociais enquanto relações sociais de produção e, principalmente, assegura tais relações enquanto de dominação, constituídas a partir das relações de classe. As bases, os fundamentos jurídicos deste Estado aparecem como direitos individuais, mas se apresentam como relações de poder entre classes postas pela separação primordial trabalho-capital. Disso resulta uma problemática, a de tornar-se esse Estado burguês um Estado total, ou seja, que possa obscurecer as relações de classe sob o manto da vontade de uma classe como vontade geral.

A produção do espaço perpassa diversas condições objetivas e subjetivas pressupostas por representações sociais, cujas formas espaciais se

Cardoso de MELLO (Metamorfoses da riqueza: São Paulo, 1845-1895. São Paulo: Hucitec, 1990) sobre as famílias enriquecidas nos momentos iniciais da urbanização de São Paulo faz um apanhado descritivo das diversas atividades econômicas oriundas daquele momento de diversificação e aumento da riqueza. 
definem no plano que articula interesses privados aos agentes reguladores do espaço. A produção do espaço se apresenta a partir do Estado como forma do político e do poder. Aliado a interesses privados, opera a partir das representações no campo das subjetividades sociais, interpostas por uma razão social em geral:

O Estado tem, com efeito, interesses próprios e por isso tende [...] a colocar-se acima da sociedade, instaurar-se, mascarando as contradições dessa sociedade, esmagando-as pela força repressiva ou dissimulando-as num nevoeiro ideológico, em resumo, tende a fazer imperar uma "razão de Estado" confundida - ideologicamente - com a "razão em geral" (LEFEBVRE, 1972 p. 147).

Produz-se então, para além da materialidade objetivada nas relações de produção, a subjetividade materializada nas ideias da classe como ideias da sociedade em geral. Este processo potencializa que a ordem burguesa se torne a ordem geral, que as ideias e revelações postos por essa classe possam subsumir as contradições imanentes que resultam da produção do valor. As ideologias tornam-se necessárias e se reproduzem também no seio das relações sociais de produção, ao movê-las em meio à nevoa espessa da sujeição do trabalho à propriedade.

As ideias da classe dominante são, em cada época, as ideias dominantes, isto é, a classe que é a força material dominante da sociedade é, ao mesmo tempo, sua força espiritual dominante. A classe que tem à sua disposição os meios de produção material dispõe também dos meios da produção espiritual, de modo que a ela estão submetidos aproximadamente ao mesmo tempo os pensamentos daqueles aos quais faltam os meios da produção espiritual. As ideias dominantes não são nada mais do que a expressão ideal das relações materiais dominantes, são as relações materiais dominantes apreendidas como ideias; portanto, são a expressão das relações que fazem de uma classe a classe dominante, são as ideias de sua dominação. Os indivíduos que compõem a classe dominante possuem, entre outras coisas, também consciência e, por isso, pensam; na medida em que dominam como classe e determinam todo o âmbito de uma época histórica, é evidente que eles o fazem em toda a sua extensão, portanto, entre outras coisas, que eles dominam também como pensadores, como produtores de ideias, que regulam a produção e a distribuição de ideias do seu tempo; e, por conseguinte, que suas ideias são as ideias dominantes de uma época" (MARX \& ENGELS, 2007 p. 47).

Criar ideias é forjar também a subsunção social à reprodução capitalista. Definir o progresso, o crescimento econômico, o desenvolvimento como ideias 
dominantes encaminha o processo social pela prática. Cria no seio da sociedade a própria ideia de pertencimento à modernidade, de fazer parte desta como expressão simbólica de desenvolvimento. Essa ideia desdobrada obscurece a substância que integra toda a sociedade, a produção do valor que emerge da relação de separação entre o trabalho e a propriedade.

Como demonstração dessa estreita relação entre o Estado e a burguesia emergente como classe dominante em São Paulo a partir da centralidade da produção de café como formação/reprodução de capital, explicadas pela expansão da cultura cafeeira em direção ao interior do estado, na marcha para o oeste que difundia a propriedade privada das fazendas de café, as políticas de proteção a esta atividade garantiam a essa fração da burguesia seus ganhos de capital de diversas maneiras, tais como, a política de subsídios à imigração defendida por personas desta classe como foi o caso do Senador Vergueiro, eminente político paulista da época (ver MARTINS, 2004 op. Cit.), ou mesmo, nas primeiras décadas do século XX, ao se definir o Estado como comprador da produção cafeeira por preços fixados a partir das condições internas de acumulação, longe dos preços internacionais regulados não somente na relação capital-trabalho, mas também nos mercados de futuros sob as oscilações cambiais e de preços das mercadorias que já naquele momento podiam ser consideradas commodities.

Foi preciso o controle governamental para fazê-la (a produção de café) crescer ou diminuir guardando certa distância das flutuações de mercado, para o que teve-se de recorrer ao controle direto (Instituto Brasileiro do Café) e aos preços sociais em lugar dos preços de mercado (OLIVEIRA, 2003 (1981) p. 41).

As garantias políticas e a estruturação do poder dominante como personificação dessa nova classe burguesa urbana em São Paulo vão se configurar como elementos fundamentais para compreender a produção do espaço, uma vez que a categoria fundamental da propriedade fundiária capitalista está posta como conteúdo dessa produção, e seu instrumental político e jurídico, o urbanismo, se referencia na própria condição de esquadrinhar o espaço de maneira que o processo social seja dado pelas normas jurídicas postas pelo Estado enquanto regulador das relações sociais de produção, pois que normatiza não somente o trabalho, mas o espaço, as 
condutas, o acesso ao que é público, a conformação do indivíduo e suas práticas sociais nas relações privadas. Um dos primeiros códigos urbanos de São Paulo, de 1886, é chamado Código de Posturas, ou seja, não se resume ao espaço urbano propriamente dito, mas que penetra no próprio corpo, tanto social como individual, ao definir padrões que vão do privado, o espaço da moradia regulado pelas exigências impostas pelos padrões residenciais; ao público, o corpo, seu movimento e comportamento nos espaços públicos e que pressupunham este como espaço de circulação regulado pelas leis que proibiam ajuntamentos, aglomerações, manifestações culturais e políticas.

O planejamento urbano surgido em São Paulo a partir dessas relações de classe e suas múltiplas derivações se consubstancia nessa forma ao mesmo tempo opressora e segregadora, pela qual as forças produtivas e as relações sociais de produção dão conteúdo à reprodução do capital em geral, assim como se traduzem em relações socioespaciais ditadas não somente pelas leis de definição do espaço, mas do próprio corpo. É interessante notar o quanto se fala em promiscuidade nos relatos e obras deste momento histórico, ou seja, o contato do corpo, as trocas corporais, os fluidos que emanam e se confundem nessa proximidade corporal, nessa aglomeração, nesse ajuntamento irremediável do espaço urbano, dos corpos tanto em movimento quanto em repouso, nos espaços de circulação pública, nas fábricas e outros ambientes de trabalho, nas formas predominantes da moradia urbana da época, fundamentalmente os cortiços.

Dessa maneira e por esses pressupostos, se definem as formas de intervenção direta no disciplinamento dos contingentes de populações de expropriados que afluíam às cidades industriais, na forma jurídica das leis de criminalização aos grupos excedentes, sem condições de se integrar à força de trabalho urbano-industrial, assim como àqueles a ela sujeitados, em todos os casos, a partir das formas do ordenamento do espaço urbano. Espaços públicos se tornam aqueles da circulação. Ajuntamentos, aglomerações, outras formas de sociabilidade não reconhecidas pelos códigos legais são prontamente combatidas. Os diversos lugares da cidade de São Paulo que se caracterizam como nós de uma rede de sociabilidade composta por diversos grupos sociais, escravos, forros, libertos, indígenas, mestiços empobrecidos, tropeiros, vendedoras de tabuleiro, lavadeiras, migrantes, enfim, são desfeitos 
para dar lugar ao que se definiu como progresso, alargamento de ruas, demolições de casarões, cortiços em sua maioria, desativação de chafarizes, o que se definiu como política higienista. Aparece, por um lado, a cidade saudável, ruas largas e moradias ventiladas, ensolaradas, propícias à reprodução da família unicelular. Se apresenta, por outro lado, a cidade privada, dos negócios, das relações de produção, da ordem, da contenção pelas classes dominantes das tensões advindas das próprias relações de classe.

Conforme Michel Foucault, tal modelo higiênico é difundido a partir de meados do século XVIII na França, na qual se produzia, naquele momento, elementos de uma "medicina social", o esquadrinhamento do espaço por meio do urbanismo como ferramenta de poder e de controle social pelo e a partir do espaço:

\footnotetext{
Ora, na segunda metade do século XVIII, se colocou o problema da unificação do poder urbano. Sentiu-se a necessidade, ao menos nas grandes cidades, de construir a cidade como uma unidade, de organizar o corpo urbano de modo coerente, homogêneo, dependendo de um poder único e bem regulamentado.

$\mathrm{E}$ isso por várias razões. Em primeiro lugar, certamente, por razões econômicas. Na medida em que a cidade se torna um importante lugar de mercado que unifica as relações comerciais, não simplesmente a nível de uma região, mas a nível da nação e mesmo internacional, a multiplicidade de jurisdição e de poder torna-se intolerável. A indústria nascente, o fato de que a cidade não é somente um lugar de mercado, mas lugar de produção, faz com que se recorra a mecanismos de regulação homogêneos e coerentes.

A segunda razão é política. O desenvolvimento das cidades, o aparecimento de uma população operária pobre que vai tornarse, no século XIX, o proletariado, aumentará as tensões políticas no interior da cidade. (FOUCAULT, 1984 p. 86).
}

São elementos de uma dominação espacial compreendidos no âmbito do planejamento estatal como processo geral, mas que se difunde e se incorpora sob as condições históricas particulares. Yves Lacoste relata tais formulações em cidades francesas a partir do "aménagement do território", em Lyon, por exemplo, nas quais o planejamento serviu como tática para manter o processo produtivo dos operários têxteis e ao mesmo tempo desarticula-los enquanto movimento de classe (LACOSTE, 2005 p. 39-40). Ou mesmo Henri Lefebvre quando nos fala das intervenções do Barão de Haussman, ou 
"urbanismo haussmaniano" como prefere o autor, na Paris do século XIX, que desarticulou os movimentos operários com a "expulsão do proletariado para a periferia, invenção simultânea do subúrbio e do habitat, aburguesamento com despovoamento e apodrecimento dos centros" (LEFEBVRE, 1999 p. 103-5).

O planejamento urbano em São Paulo desde fins do século XIX vai se constituir na força motriz destinada a intervir nas contradições postas pela relação capital-espaço. É desde esse período que populações empobrecidas tornam-se alvo das decisões políticas e da jurisprudência que define seu lugar no espaço da metrópole: "mais além do que definir as formas de apropriação do espaço permitidas ou proibidas, mais do que efetivamente regular a produção da cidade, a legislação urbana age como um marco delimitador de fronteiras de poder" (ROLNIK, 2003 p.13).

Raquel Rolnik (op. Cit.) lembra a ambiguidade assumida pelas leis de ordenamento do espaço como momento de remoção/expropriação dessas populações das áreas de interesse dos investimentos na cidade de São Paulo assim como possibilidade de reprodução dessa mesma população em outras áreas:

A ambiguidade consistia na criação, dentro da ordem legal, de uma possibilidade de escapar à lei, definindo um espaço - a área suburbana e mais tarde a rural - em que isso poderia acontecer, sem ficar, entretanto, sob a responsabilidade do estado. Embora a possibilidade de não se obedecer à lei fosse parte da própria ordem, a condição de morador de uma habitação coletiva ou de ocupante de espaço público de um modo não previsto na lei era rejeitada por essa mesma ordem (idem p. 59).

Vão se constituindo objetivamente os elementos estruturais da relação capital-espaço, ou seja, uma população definida como não proprietária, ou mesmo proprietária de lotes ilegais e/ou irregulares diante de uma legislação que irá requerer tais espaços como forma de intervir nas contradições postas por aquela relação:

Assim, todas as definições de legislação urbanística que interferem diretamente no potencial de valorização dos terrenos urbanos acabam por ter uma importância que vai além das simples limitações de ordem técnica ou estética, interferindo em uma reserva de valor historicamente estratégica (idem, $p$ 25). 
Diante de uma aparente dualidade que define o legal e o ilegal, o regular e o irregular, se situa uma lógica da produção desigual do espaço urbano, fundamental para a compreensão das atuais condições da produção do espaço, mas que constituídas historicamente no interior das relações políticas ao definir o espaço enquanto relação desigual de poder definida pela própria condição histórica da urbanização, "enquanto os projetos de lei constituíam ideias fora do lugar, um lugar estava sendo produzido sem que dele se ocupassem as ideias" (MARICATO, 2000 p. 151).

Neste período, as políticas higienistas irão incluir em seu escopo jurídico os ambientes fluviais das várzeas da metrópole paulistana. Dessa política surgem formas de apropriação desses ambientes fluviais que irão se constituir historicamente num processo que perpassa desde as políticas sanitárias de fins do século XIX até as políticas ambientais do início do século $X X I$, de maneira que tais ambientes são incorporados ao espaço da metrópole de diferentes formas, sob as relações contraditórias capital-espaço a partir dessas condições de apropriação historicamente constituídas.

No momento atual, em que as condições de reprodução se situam, sobretudo, em grandes massas de capital financeiro na busca de realização, tais ambientes fluviais se apresentam inseridos na lógica da produção do espaço como possibilidade para a realização das condições requeridas pela atualidade da relação capital-espaço.

Novamente, populações empobrecidas se situam no interior dessa lógica, como necessárias tanto naquelas condições primordiais do processo de acumulação, enquanto se constituía uma força de trabalho urbana e industrial, quanto agora, como juridicamente despossuídas e, dessa forma, incluídas no processo de reprodução na relação capital-espaço. E é dentro de uma juridiciação do espaço que se define a ordem urbanística, não pela existência jurídica em si, mas pela ordem que se apresenta a partir das contradições postas pelo movimento do capital e suas condições de reprodução, ou seja, que lei e ordem se relacionam na unidade da relação capital-espaço:

Um abundante aparato regulatório normatiza a produção do espaço urbano no Brasil - rigorosas leis de zoneamento, exigente legislação de parcelamento do solo, detalhados códigos de edificações são formulados por corporações profissionais que desconsideram a condição de ilegalidade em que vive grande parte da população urbana brasileira em 
relação à moradia e à ocupação da terra, demonstrando que a exclusão social passa pela lógica da aplicação discriminatória da lei. A ineficácia dessa legislação é apenas aparente, pois constitui um instrumento fundamental para o exercício arbitrário do poder além de favorecer pequenos interesses corporativos (Idem, p. 147).

A existência jurídica da propriedade é a condição de sua inexistência, e que a constituição jurídica do espaço enquanto propriedade não define sua expropriação no campo da não-propriedade, mas no campo da ordem urbanística. É a produção do espaço a chave dessa compreensão. 


\section{Capítulo VI}

\section{Periferização}

Ao longo da metropolização de São Paulo se reconhece, sobretudo nas décadas de 1960 e 1970, uma condição objetiva do espaço posta como relação centro-periferia observada sob diferentes critérios. A morfologia contrapõe o próximo e o distante, disperso e o concentrado, o horizontalizado e 0 verticalizado, o "contemporâneo" e o "atrasado", o que está pronto e o que está por se fazer:

A forma da cidade que se infere como morfologia permite apreender estabilidades provisórias, equilíbrios momentâneos; coloca-nos diante da duração, daquilo que persiste e daquilo que se rompe, expondo dessa forma a dialética da continuidade/descontinuidade (CARLOS, 2001, p. 46).

Claro que estes termos contrapostos não se realizam como homogeneidade, como condição única e precisa de seu conteúdo e expõem uma complexidade de formações socioespaciais. No entanto, vistos assim, como uma relação de polos opostos, acabam por se tornar indistintos em seu interior e apenas sê-lo na e pela relação que os contrapõe. O que se pretende é o pensamento sobre o processo da metrópole explicado no interior desta relação, a qual se metamorfoseia em novas formas de reprodução que incluem a fragmentação constitutiva da metrópole como conteúdo próprio dessas novas formas.

O momento ao qual se refere o duplo processo urbanizaçãoindustrialização, que desde fins do século XIX em São Paulo produziu formas de moradia relacionadas à exploração da força de trabalho, já definia a complexidade no interior da espacialização centro-periferia. A pobreza e suas formas de reprodução como cotidiano expresso pela população que se constituía enquanto força de trabalho já expunha que o centro não o era em si, mas que já se definia como fragmentado. Contrapunham-se neste processo diferentes grupos sociais que no e pelo espaço situavam suas formas de uso, de maneira que grupos dominantes estabeleciam, pela via da expropriação baseada na legislação, mecanismos para manter afastados outros grupos sociais e suas manifestações. Não era somente o estabelecimento na forma da 
moradia, mas outras formas de uso do tempo também compunham as lógicas de segregação, ligadas ao cotidiano do trabalho, como vendedoras de tabuleiro, lavadeiras, carregadores, espaços públicos como os chafarizes que possibilitavam o encontro de diversos grupos, outras formas mais lúdicas de uso do tempo como a capoeira e as rodas de samba e tiririca; que expunham manifestações populares, mas que também são lidas como conflitos expressos em territórios de luta política entre frações de classes. Foram evidentes tais conflitos nas inúmeras reformas urbanas que procuravam homogeneizar certas parcelas do espaço como territórios das classes dominantes e das formas de realização de seus negócios, como foi o caso das políticas do Prefeito Antonio Prado $^{57}$.

Tal situação evidenciava uma fragmentação no interior daquilo que se constituía como centro, inclusive pela sempre presente periferização, explicitada nas formas de expulsão de populações empobrecidas das áreas de interesse e predomínio das classes dominantes e suas frações. Tais situações se objetivavam nos espaços periféricos contíguos aos da referida classe, como foram a Barra Funda e o Bexiga relativamente aos Campos Elíseos e Higienópolis assim como à Avenida Paulista. A força de trabalho, inclusive aquela destinada aos serviços domésticos da classe dominante, habitava os espaços à margem das áreas de valorização e de moradia da abastada elite paulistana ${ }^{58}$. Constituíam-se, sobretudo de lavadeiras, arrumadeiras, domésticas e pessoas que executavam serviços gerais. Também foi significativo o exemplo dos chamados bairros operários, majoritariamente de imigrantes, mas que também encerravam populações empobrecidas nacionais, negros, mestiços, enfim, e que também foram dispostos "afastados" das áreas de interesse e se caracterizaram principalmente pela sua situação geográfica tratada por alguns autores de "bairros além-Tamanduateí" ${ }^{59}$.

57 Antonio da Silva Prado foi prefeito de São Paulo na virada do século XIX para o XX.
Implantou políticas higienistas que resultaram em inúmeras reformas urbanas, principalmente
àquelas que diziam respeito aos rios e várzeas das regiões centrais. Em sua gestão foi
implementada a concessão para a empresa Light and Power, também responsável por
transformações significativas nos ambientes fluviais. Antonio Prado é um significativo
representante da classe dominante oriunda da cafeicultura do oeste paulista, com suas
derivações econômicas (bancos, companhias de imigração e de estradas de ferro) e políticas.
58 Ver capítulo 02 (p. 59-96) da obra de Raquel Rolnik: A Cidade e a Lei (ROLNIK, 2003, op.
Cit.).
59 Os trabalhos de Renato da Silveira MENDES (In: Aroldo de AZEVEDO: A Cidade de São
Paulo. São Paulo: Ed. Nacional, 1958 p.227 a 255) e Margarida M. Andrade (in CARLOS \& 
As relações socioespaciais se constituíam no interior de um processo que se supunha homogêneo, mas que se revelava como conflito, como é o caso das populações de encortiçados, ao reproduzir seu cotidiano empobrecido no próprio centro, o qual se pressupunha espaço homogêneo, definido pelas políticas de valorização e pela presença das esferas dominantes paulistas, no interior do qual se reproduzia uma parcela da população proletária e seu cotidiano precarizado, fato que desde sempre expôs uma fragmentação daquilo que se convencionou chamar de centro.

Da mesma forma, a extensão das moradias precárias, a periferização do proletariado urbano pelas áreas então rurais e ao mesmo tempo de moradia de frações abastadas da cidade, formava também um espaço fragmentado, posto pelo surgimento de moradias proletárias ao redor das chácaras e sítios dos grupos dominantes, até pelo próprio loteamento destes. São exemplos que até hoje podem ser vistos, a "Casa da Dona Yayá", na rua Manoel Dutra, no Bexiga, antigo sítio da família Mello Freire, representantes dos grupos dominantes paulistas, assim como a "Casa do Regente Feijó" no badalado e hipervalorizado Jardim Anália Franco ${ }^{60}$.

Desde as décadas iniciais deste processo até a atualidade, a moradia dita precária sempre manifestou a condição de pobreza associada à própria produção da riqueza. Lucio Kowarick denominou essa contradição de "espoliação urbana" ao considerar a produção material possibilitada por esse enriquecimento dissociada do lugar de moradia e do cotidiano do proletariado que a produziu. Mais do que isso, o cotidiano se fazia ele mesmo espoliado, precariedade da moradia, do deslocamento, da alimentação, dos serviços urbanos como um todo (KOWARICK, 1993). Marx já nos revelava nos Manuscritos Econômico-Filosóficos de 1844 (op. Cit.) que este processo é pressuposto da separação propriedade-trabalho, da qual resulta que o próprio

OLIVEIRA (org.) São Paulo: Metrópoles. São Paulo: EDUSP, 2004 p.171-192) relatam a formação dos bairros além Tamanduateí, para onde se dirigiam (e eram dirigidas) uma parte das populações empobrecidas, sobretudo os imigrantes, os subúrbios orientais de São Paulo, naquele momento uma área integrada ao mesmo tempo em que apartada da cidade. Nos dizeres de MENDES (op. Cit) a Penha era a "porta oriental da cidade".

${ }^{60}$ A "casa da Dona Yayá" é tombada pelo Patrimônio Municipal (COMPRESP) e pertence à Universidade de São Paulo, é um espaço da Pró-Reitoria de Cultura e Extensão e se destina a manifestações culturais, assim como permite o acesso público. A "Casa do Regente Feijó" rodeada por arranha-céus residenciais é propriedade da Universidade Cruzeiro do Sul (UNICSUL), também tombada e mantida como patrimônio sob concessão, cujo acesso é restrito e somente pode se realizar a partir da prévia autorização desta Universidade. 
corpo do trabalhador lhe é separado na relação. Suas forças e seus pensamentos somente se transformam em trabalho nesta e por esta relação de separação, na medida em que se defrontam com a propriedade. Uma vez posta a separação capital-trabalho, se define a lógica da apropriação da riqueza produzida enquanto lógica de classes, a contradição se revela intrínseca ao processo e expõe a fragmentação socioespacial própria desta relação contraditória, ou seja, o espaço dessas relações revela a marca das contradições pela fragmentação, pela separação, e ao mesmo tempo, pela junção de um todo complexo no espaço da metrópole, que une separadamente os fragmentos postos e dispostos pelas relações sociais de produção.

Ao mesmo tempo em que ocorria a fragmentação interna ao centro, se estabelecia também um "padrão periférico"61 de crescimento possibilitado, sobretudo, por um mercado de terras nas áreas distantes do centro, conjugado a uma expansão, mesmo que insuficiente, dos serviços de transporte, sobretudo na mudança da modalidade do bonde para o ônibus como novo padrão de deslocamento urbano ${ }^{62}$. Os antigos núcleos rurais que circundavam a cidade de São Paulo passaram a se reproduzir como moradia da classe trabalhadora, enquanto as franjas da cidade avançam em direção àqueles. É a extensão do tecido urbano ${ }^{63}$ que se espraia por vastas áreas a confinar seus arredores rurais dentro de si, a difundir não somente a forma urbana em si, mas suas manifestações, predispondo o urbano como devir social e espacial, a forma daquilo que se definiu no campo dos estudos urbanos como "mancha urbana". No entanto, este processo não se dá somente como forma, como mancha urbana em si, mas como redefinição das relações sociais agora postas pela forma-conteúdo urbana. A este crescimento extensivo como forma, se redefinem as relações sociais como conteúdo.

À dimensão intensiva das metamorfoses do espaço corresponde outra, extensiva, que dispôs a reprodução desmesurada do espaço metropolitano. Se expressam negativamente quantidades e qualidades, naquilo que Henri Lefebvre conceituou de implosão-explosão da "cidade":

61 O "Padrão Periférico de Crescimento" foi a designação mais difundida pelas correntes de estudos urbanos para referenciar o que denominamos de periferização, a extensão horizontalizada e desmesurada do espaço urbano, na forma de uma grande "mancha urbana" que corresponde à área urbanizada da Metrópole.

${ }_{62}$ Ver KOWARICK \& ANT in KOWARICK, 1994 pp 73-93

${ }^{63}$ Ver Henri LEFEBVRE, 2004, p.17-8. 
(metáfora emprestada da física nuclear), ou seja, a enorme concentração (de pessoas, de atividades, de riquezas, de coisas e objetos, de instrumentos, de meios de pensamento) na realidade urbana, e a imensa explosão, a projeção de fragmentos múltiplos e disjuntos (periferias, subúrbios, residências secundárias satélites, etc.) (LEFEBVRE, 2004 p.26).

Não podemos referir tal contradição à forma, objetivação material de uma concentração e de uma dispersão que ocorrem simultaneamente, mas que tais condições acontecem no interior de uma relação negativa não somente entre quantidades e qualidades, mas também entre forma e conteúdo. Henri Lefebvre nos coloca diante do devir, de um processo que simultaneamente reproduz uma forma desmesurada tanto interna quanto externamente, no interior da qual qualitativamente se expõem os extremos dessa forma, sem que aquilo que os qualifica possa suprimir aquilo que, ao mesmo tempo, os desqualifica. A urbanização é assim antitética e se revela no movimento entre forma e conteúdo:

Separando-se do conteúdo, forma se separa do concreto [..] Não há forma sem conteúdo, não há conteúdo sem forma. Aquilo que se oferece à análise é sempre uma unidade entre a forma e o conteúdo [...] A unidade, indissolúvel e no entanto rompida pela análise é conflitante (dialética) (LEFEBVRE, 2001 P.87).

A inserção de São Paulo num processo que a viria intensificar e diferenciar a produção da riqueza mostra-se, ao longo da história, como um processo geral que, inserido na lógica mundial da reprodução capitalista, se faz em condições particulares. Conforme Ana Fani A. Carlos, "o processo urbano não sinaliza um movimento que iria do local ao global, mas uma articulação de níveis de análise justapostos, tendo a metrópole como mediação entre eles" (CARLOS, 2005 p. 31).

Articulam-se os momentos dessa inserção de maneira a produzir internamente uma relação negativa da qual resulta o espaço como expressão de riqueza e pobreza ao mesmo tempo, não como casualidade, menos ainda como dualidade, mas como relação definida no interior do processo. Tal é a definição da metropolização como processo cuja análise se situa na relação contraditória entre suas categorias. Ao contrário de uma "modernização incompleta", temos uma modernização que se define pela negatividade e, no 
interior desta, as mazelas como a concentração de renda, nada mais são que a expressão pura e simples das formas históricas de acumulação. Conforme nos apresentou Francisco de Oliveira (2003 p. 46-7), a exploração intensiva e extensiva da força de trabalho produziu uma "estranha forma de 'economia de subsistência' urbana", expressa na pauperização exacerbada, enquanto a "produtividade industrial crescia enormemente" dando "margem à enorme acumulação". Conforme o autor, "nessa combinação é que está a raiz da tendência à concentração de renda".

Alguns autores expuseram de que maneira a reprodução das relações sociais de produção constituem em si a definição do espaço enquanto momento dessas relações ${ }^{64}$. A metropolização expõe tais relações ao definir a periferização como reprodução da força de trabalho, não separada, mas intrínseca ao processo de acumulação, ou seja, não como dualidade que se define como pobreza e riqueza, arcaico e moderno, mas como expressão daquele processo em si.

Ao se apropriar das formulações de Francisco de Oliveira, Ermínia Maricato analisa de que maneira se combinam as formas de produção da moradia com o processo de acumulação que resulta na morfologia da autoconstrução:

É principalmente através da autoconstrução que a maioria da população trabalhadora resolve o problema da habitação, trabalhando nos fins de semana, ou nas horas de folga, contando com a ajuda de amigos, parentes, ou contando apenas com a própria força de trabalho (marido, mulher e filhos) [...] A construção da casa se estende por muitos anos absorvendo a maior parte das economias conseguidas sempre em prejuízo de outras necessidades, já que o salário é baixo para suprir satisfatoriamente todas as necessidades que tem a classe trabalhadora para se reproduzir, em meio ao urbano. (MARICATO, 1982 p. 73).

Francisco de Oliveira, ao analisar a condição proposta anteriormente de uma "economia de subsistência urbana" revela um processo que na aparência é definido como "caótico", "desordenado", mas nada mais é do que a expressão das relações sociais de produção postas por um regime de acumulação baseado em extensiva exploração da força de trabalho, como um supertrabalho, extensão do trabalho necessário para além daquele definido

${ }^{64}$ Ver os capítulos de Ermínia MARICATO (p. 71 a 93) e Raquel ROLNIK \& Nabil BOUNDUK (p.117 a 154) in MARICATO, 1982. 
pela jornada, processo que expropria também o tempo-livre, ao torna-lo extensão do trabalho necessário como trabalho não-pago:

Ora, o processo de crescimento das cidades brasileiras não pode ser entendido senão dentro de um marco teórico onde as necessidades de acumulação impõem um crescimento dos serviços horizontalizado, cuja forma aparente é o caos das cidades. Aqui, uma vez mais, é preciso não confundir "anarquia" com caos; o "anárquico" do crescimento urbano não é caótico em relação às necessidades de acumulação: mesmo uma certa fração da acumulação urbana, durante o longo período de liquidação da economia pré-anos 1930, revela formas do que se poderia chamar, audazmente, de "acumulação primitiva". Uma não insignificante porcentagem das residências da classe trabalhadora foi construída pelos próprios proprietários, utilizando dias de folga, fins de semana e formas de cooperação como o "mutirão". Ora, a habitação, bem resultante dessa operação, se produz por trabalho não pago, isto é, supertrabalho. Embora aparentemente esse bem não seja desapropriado pelo setor privado da produção, ele contribui para aumentar a taxa de exploração da força de trabalho, pois seu resultado - a casa - reflete-se numa baixa aparente do custo de reprodução da força de trabalho - de que os gastos com habitação são um componente importante - e para deprimir os salários reais pagos pelas empresas. Assim, uma operação que é, na aparência, uma sobrevivência de práticas de "economia natural" dentro das cidades, casa-se admiravelmente bem com um processo de expansão capitalista, que tem uma de suas bases e seu dinamismo na intensa exploração da força de trabalho (OLIVEIRA, 2003 p. 59).

O duplo urbanização-industrialização sedimentou a formação de um vasto contingente de força de trabalho a mover o processo produtivo. De diferentes formas, tal contingente se estabeleceu na "cidade" não de maneira passiva, mas a constituir, sob as relações sociais de produção, a própria metamorfose desta em metrópole. No interior deste processo, a reprodução dessa força de trabalho na sua relação com a propriedade privada acabou por definir o que seriam os espaços empobrecidos que, desde seus momentos iniciais, evidenciaram mais do que a simples diferenciação do espaço, e sim o próprio dilaceramento vivido como reprodução. Os cortiços (que predominaram na primeira metade do século XX e ainda hoje aí estão, seja no centro ou nas periferias), as favelas, os "loteamentos clandestinos", os moradores de rua, os espaços empobrecidos e pauperizados da metrópole, tudo isso corresponde às definições do espaço como produto das relações sociais de produção, 
definidoras, portanto, da realização da metrópole no âmbito das relações socioespaciais.

Se constituem historicamente os espaços empobrecidos da metrópole os quais, em diferentes momentos e de diferentes maneiras, se apresentam como potenciais espaços a serem requeridos por sua condição jurídica de nãopropriedade, apesar de sua formação intrínseca ao próprio processo de reprodução enquanto reprodução da pobreza, das relações sociais de produção que envolvem uma multidão de trabalhadores na busca por moradia:

[...] uma parte correspondente da população não tem meios para pagar pelo direito de ocupar um pedaço do solo urbano. Esta parte da população acaba morando em lugares em que, por alguma razão, os direitos da propriedade não vigoram: áreas de propriedade pública, terrenos em inventário, glebas mantidas vazias com fins especulativos, etc., formando as famosas "invasões", favelas, mocambos, etc... Quando os direitos da propriedade privada se fazem valer de novo, os moradores das áreas em questão são despejados, dramatizando a contradição entre a marginalidade econômica e a organização capitalista do uso do solo (Paul SINGER, in MARICATO, 1982 p. 33-4. As aspas são nossas).

Vastas áreas do espaço metropolitano em São Paulo se constituem como moradia não regularizada, o que inclui formas de moradia não reconhecidas pelo escopo jurídico que fundamenta a propriedade do solo urbano. Os moradores dessas áreas empobrecidas não se compõem somente daqueles cuja condição é "sobrar" no mercado da mão de obra, mas também daqueles que se empregam de maneira formal neste mesmo mercado. Tratase de mecanismos de exploração e de expropriação cujo próprio trabalho, ainda que formal, é a condição em si da pauperização.

As condições de moradia no meio urbano pressupostas pelo acesso às parcelas do solo como forma mercadoria resultou em práticas diferenciadas, tanto para sustentar um mercado "formal" de terras, com embasamentos jurídicos das condições legais propostas para a regularização formal da propriedade privada, como um mercado dito "irregular" que se estende desde áreas loteadas e vendidas por grupos "imobiliários", compostos fundamentalmente por loteadores e donos de terras, principalmente naquilo que eram os arredores rurais da cidade, até formas mercantis presentes nos terrenos de ocupação. São as estruturações formais do acesso à terra postas pelas condições de mercantilização num circuito que corresponde à população 
empobrecida ${ }^{65}$ e que realiza aquilo que é denominado "informal", longe dos preceitos jurídicos pressupostos pela propriedade privada do solo urbano.

$\mathrm{Na}$ maioria desses loteamentos, a situação de regularização se deu posteriormente à própria urbanização, em alguns casos, muitos anos após, décadas depois da abertura dos lotes. Alguns exemplos revelam o quanto as infraestruturas modificaram as feições da área, inclusive no que diz respeito ao preço dos lotes referenciado por estas. É necessário pensar também que toda a sorte de negócios eram realizados mesmo sem a documentação oficial, o amparo jurídico da propriedade.

A periferização na metrópole de São Paulo aconteceu, do ponto de vista jurídico, de maneira quase totalmente "informal", até pelas condições intrínsecas de sua realização. Pensar que a formação desta metrópole, sua periferização, aconteceu praticamente sem crédito bancário soa como absurdo. No entanto, o parcelamento do solo e os ganhos de capital previstos para os grupos que atuavam neste processo, fundamentalmente loteadores e proprietários de terra, eram calculados pela antecipação, a chamada "entrada" que os compradores davam para a aquisição do lote, e pelas prestações, ao longo de muitos anos, pagas diretamente aos loteadores, fossem ou não imobiliárias. Era este cálculo que definia os ganhos dos envolvidos na formação dos loteamentos sem que necessariamente os compradores tivessem que recorrer ao crédito bancário, até porque o fenômeno creditício estava fora do alcance de grande parte da força de trabalho. Dessa forma, as questões jurídicas pertinentes à propriedade formal da terra eram deixadas de lado, pois não cabiam no cálculo tanto de quem vendia quanto de quem comprava.

Acontece que, do ponto de vista das relações de produção, a reprodução da classe trabalhadora configurava-se como acumulação na outra ponta, pois que o mecanismo de retração dos salários, ou seja, extração máxima de mais-valia, se perpetuava para além da jornada e se constituía também nas formas de reprodução da força de trabalho, ao expropriar parcelas do tempo livre, ao constituir-se como sobretrabalho. Dessa maneira, tornava-se impossível pensar na moradia do proletariado urbano como processo jurídico

${ }^{65}$ Sobre os loteamentos nas áreas periféricas ver ROLNIK \& BOUNDUKI in MARICATO, 1982 p. 117 a 154 , op. Cit.. 
formal, uma vez que este iria requerer outras condições de remuneração deste mesmo proletariado, ou seja, pressupor outros níveis de remuneração redefinidos pela diminuição das taxas de mais-valia, algo fora da lógica da exploração vigente naquele momento. Diante dessa realidade, o Estado como entidade política era uma presença-ausência, pois ser ausente era a maneira como o Estado presenciava e permitia a reprodução da "ilegalidade", pois que esta era fundamento do próprio processo de acumulação.

Sob tais condições é que se produzem os elementos históricos os quais nos permitem entender o espaço como produção desigual no interior da reprodução social posta pelas necessidades do capital, como condição e estruturação de suas categorias. Trata-se, portanto, da reprodução de relações sociais que conduzem às formas que revelam tais relações no âmbito da reprodução socioespacial como forma desigual de um processo histórico no qual as categorias se defrontam, se movem pela negatividade intrínseca de sua essência. 


\section{Capítulo VII \\ Metamorfoses nas Relações Socioespaciais}

As relações primordiais que estruturaram as categorias elementares do capitalismo, como são a propriedade privada e o trabalho, são apreendidas pelas contradições enquanto movimento, processo histórico. As categorias se apresentam como conteúdo, mas que, no movimento posto por suas relações, redefinem as formas, pois que o movimento é crítico e as metamorfoses dessa relação são imanentes.

Disso resultam condições outras para pensarmos o espaço e sua forma como resultado e processo das relações sociais de produção. Ao se reestruturarem estas, o espaço e sua condição imanente de produto social também se modifica, torna-se forma da reestruturação das relações sociais, ou seja, ao mesmo tempo, são estas e aquele formas-conteúdo do movimento histórico. Os rearranjos na reprodução das relações sociais postas pelo movimento crise-acumulação tornam-se condição imanente das metamorfoses do espaço da metrópole.

Ao revermos algumas condições históricas, ou seja, do movimento das formas-conteúdo nas últimas décadas na metrópole de São Paulo, verificamos transformações significativas no processo produtivo. Sempre houve uma predominância do setor terciário da população economicamente ativa, mas acompanhado por um setor industrial que ocupava significativa parcela desta população e com relativa importância na composição geral da riqueza. Mas, a partir de fins da década de 1970 tal composição tem se transformado. Como chama atenção Ana Fani A. Carlos, há uma "desconcentração industrial acompanhada de uma centralização financeira" (CARLOS, 2005, p. 32).

As redefinições estruturais que se objetivam no atual momento do capitalismo perpassam as diversas categorias de compreensão do processo como um todo. Não se trata somente de uma reestruturação das formas espaciais, mas que as próprias condições da produção/acumulação também se redefiniram a partir das transformações estruturais da reprodução capitalista, pois as determinações da categoria força de trabalho há tempos se modificaram em vários níveis, não somente na oferta de emprego, mas 
também a partir de novas formas de organização do trabalho, principalmente aquelas que redefinem os vínculos empregatícios. Assiste-se a um fenômeno que tornou mais extensivas e intensivas as formas de precarização, diante das quais se apresenta um contingente populacional cada vez mais vasto inserido precariamente neste processo ${ }^{66}$. No entanto, tais condições novas de inserção de um proletariado cada vez mais precarizado, o que leva alguns autores a preferirem o termo "precariado" 67 , casam-se perfeitamente aos novos termos da reprodução capitalista, o que redefine também as condições desse novo momento para o espaço urbano.

As nuances da força de trabalho constituíam diferenciações no seio da esfera produtiva, ao se conformarem desde contingentes de assalariados com registro em carteira e certas garantias jurídicas da legislação trabalhista até outros inseridos sem nenhuma formalidade neste processo. Aos primeiros, por exemplo, a condição formal do trabalho possibilitava que a própria formalização estabelecesse formas de reprodução particulares ao predispor acesso a poupanças institucionais, pois em situações de demissão, receberia a "indenização", o Fundo de Garantia por Tempo de Serviço. Como nos lembrou Jose de Souza Martins (MARTINS, 2004 p. 148-9) a demissão, um momento que expõe as contradições de classe na relação trabalho-capital, tornava-se momento de "júbilo", até porque possibilitava para estes trabalhadores, pela via da indenização, um saldo que poderia ser usado para a compra ou reforma do imóvel, ou mesmo que permitia-Ihes tornarem-se donos de seu próprio negocio, recriava no seio da própria força de trabalho a ideologia burguesa difundida como obscurecimento das relações de classe, o ideal de libertação do trabalhador na perspectiva do burguês, $O$ "trabalho para si como libertação do trabalho para os outros" (ibidem).

Diferentes formas de inserção do proletariado urbano correspondiam ao próprio processo industrial, constituído não somente de grandes empresas, motivo de orgulho nos discursos da época, como também de uma diversidade

\footnotetext{
${ }^{66}$ Sobre as novas condições no mundo do trabalho, as formas de precarização, as mudanças estruturais, as diversas condição de contratação, tais como as terceirizações, assim como a intensificação de formas de exploração intensivas e extensivas, ver Ricardo ANTUNES: Adeus ao Trabalho? São Paulo: Cortez, 2012. Sobre as mudanças nos indicadores de emprego, precarização, inserção precária, transformações no perfil etário e outros dados em São Paulo, ver Marcio POCHMAN: A Metrópole do Trabalho. São Paulo: Brasiliense, 2001.

${ }^{67}$ ANTUNES, R., 2012 op. Cit.
} 
daquilo que até poderia não ser considerado industrialização. No trabalho de Milton Santos (SANTOS, 2012 p. 79-107) nos é apresentada outra industrialização, distinta daquela espetacularizada das grandes unidades produtivas, altamente tecnológicas, mas ao mesmo tempo convivendo com estas, de fabriquetas, baseadas numa exploração extensiva da mão de obra, em formas de contratação que dispensam qualquer formalidade, e ainda uma jornada extensiva baseada em remuneração mínima. Como este autor definiu, integravam-se e distinguiam-se circuitos econômicos por ele denominados como "superior e inferior", os quais compunham um processo de divisão do trabalho e, neste sentido, combinavam-se como diferentes e necessários enquanto momentos da produção, esta que requeria formas precárias de inserção produtiva, assim como tecnologias menos intensivas. De qualquer maneira, a força de trabalho se inseriu neste processo de forma precária e assim se constituiu enquanto contingente de trabalhadores empobrecidos, cujas necessidades de reprodução situam-se nas demandas produtivas do próprio "circuito inferior", ou mesmo daquele que integra a tecnologia mais moderna e produz mercadorias baratas destinadas ao consumo para este contingente empobrecido.

Tais condições de produção revelam uma industrialização deveras diferenciada e põem também a formação de sua mão de obra como identidade negativa enquanto força de trabalho, diante de uma precarização que se estende para a reprodução espacial na metrópole. As extensas áreas periféricas, no mais das vezes, longínquas, são condição de distanciamento não somente daquilo que é material, serviços urbanos, etc., mas como condição da própria inacessibilidade ao urbano como cotidiano, como apropriação. Se constituem dessa forma e para esses grupos "como perda da fluidez da vida urbana, como perda da vida urbana propriamente, e de suas possibilidades" (DAMIANI, 1993 p. 14).

Diante da imobilidade própria dessa população, aqui entendida como a impossibilidade da fruição, da apropriação do urbano, próprias de seu confinamento nas periferias da metrópole, realiza-se a mobilidade como busca por moradia. As contingências da apropriação do espaço urbano como moradia nessas longínquas periferias, cerceada pelas relações de toda a ordem postas pela propriedade privada do solo urbano, acabam por definir processos sociais 
os mais diversos, derivados de um mercado de terras tido como "irregular", mas que se ajusta perfeitamente às condições impostas pela própria propriedade privada enquanto categoria que define a forma de inserção dessa população empobrecida e cujos negócios se realizam num quadro de mercantilização inclusive especulativo.

O próprio processo de especulação urbana se constituía, especialmente, através da criação de pequenas empresas vinculadas aos negócios imobiliários combinando uma mudança explosiva na produção do espaço urbano da cidade, com o perfil de empreendimentos familiares (DAMIANI, 2000 p. 24).

Ora sob a condição de proprietários, seja de loteamentos na maioria os ditos "clandestinos", seja como mutuários do Sistema Financeiro de Habitação, nos conjuntos habitacionais produzidos pelos programas de habitação do Estado, como as Cohab's ${ }^{68}$; ora na condição favelados, ao ocupar terrenos, na maioria públicos, mesmo longe daquilo que se considera a propriedade formal da terra, a condição de acesso à esta se constitui a partir da compra num mercado que engloba este tipo de terras e seu comércio específico. Percebese a fragmentação da "apropriação privada" da terra no mercado urbano, o qual se realiza em diferentes condições da produção do espaço associadas às nuances das formas de mercantilização.

Nesse aspecto, passam a se diferenciar também os investimentos públicos e privados na objetivação de infraestruturas e serviços urbanos disponibilizados no espaço da metrópole, fato que resulta em formas diferenciadas de apropriação deste mesmo espaço, desde condições de circulação na metrópole até formas de uso do tempo livre no cotidiano dos moradores. Por outro lado, definem também a permanência ou a mudança dessas populações definida nos termos de uma valorização incompatível função do processo ligado à questão fundiária, basicamente seu preço no mercado de terras definido pelos mecanismos da renda fundiária, pela maneira como esta representa o trabalho social como preço de uma mercadoria:

${ }^{68}$ Ver Marcio Rufino SILVA: Mares de Prédios, Mares de Gente: Território e Urbanização Crítica em Cidade Tiradentes. São Paulo: Dissertação de Mestrado, FFLCH-USP, 2008; e DAMIANI A. L. (1993, op. Cit.). Estes dois autores trabalham não somente o papel das instituições de produção de habitação popular nas distantes periferias, como a Cidade Tiradentes na Zona Leste de São Paulo, mas o cotidiano e suas relações definidas por essas formas de institucionalização. 
Em princípio, a renda fundiária é um tributo que a sociedade paga à propriedade da terra. Mas a renda fundiária traduz também o valor do lugar, um valor que transita pelo universo simbólico da sociedade como valor histórico e um valor que transita pela maior ou menor rentabilidade econômica da utilização da terra para este ou aquele fim, como resultado de investimentos produtivos no lugar ou também como localização, acessibilidade do lugar (SEABRA, 1988 p.101).

Os fundamentos do preço das propriedades privadas passam a se referenciar nos lugares da metrópole a partir da equivalência proporcionada pelo trabalho social incorporado à terra nesses lugares, tanto no lote em si como no entorno. Na medida em que a metrópole torna-se uma massa de capital fixo, de estruturas as mais diversas que dinamizam a produção e a circulação de mercadorias, sejam estas materiais, mão de obra ou proporcionem outras formas de consumo como o uso do tempo, os referenciais que fundamentam a equivalência da propriedade privada se modificam, mas o fazem num processo que é social, que está no cerne do desenvolvimento das forças produtivas da sociedade, e remuneram a propriedade privada por sua condição de se apropriar do trabalho social, de representá-lo na forma dinheiro como preço da terra. Nos termos deste processo:

As melhorias incorporadas ao solo passam a pertencer ao proprietário dele, como acidente inseparável da substância, o solo. [...] Vende, além da terra, o solo melhorado, o capital incorporado à terra e que nada lhe custou. [...] Aí está um dos segredos - se abstrairmos do movimento da renda fundiária propriamente dita - do enriquecimento ascendente dos proprietários das terras, do aumento contínuo de suas rendas e do valor monetário crescente de suas propriedades como progresso do desenvolvimento econômico (MARX, 1980 p. 711-2).

Não é somente neste aspecto da objetivação das estruturas físicas que os lugares se diferenciam conforme os investimentos, mas principalmente no interior destes se re-significa o cotidiano dos moradores. Ao se constituir uma fragmentação extensiva do espaço, constitui-se também uma nova condição para que os investimentos possam se inserir de variadas formas ao dispor desta fragmentação como possibilidade de realização dos negócios com a terra. É o que se tem notado nos últimos anos na metrópole de São Paulo, pois, sob diversos aspectos, surgem múltiplas centralidades as quais resignificam a mercantilização do espaço, o preço do metro quadrado em 
diferentes áreas. São cada vez mais comuns diversos investimentos e infraestruturas em áreas da metrópole antes consideradas como periferias ${ }^{69}$. É nessa mesma lógica que se reestrutura também o cotidiano de uma parcela da população que habita tais áreas ${ }^{70}$.

Esse movimento revela também outra lógica da representação do preço da terra pela financeirização, lógica essa que se define pelos investimentos em dados lugares, mas que também paira sobre o preço geral da terra a partir dos referenciais cada vez mais sustentados pela disponibilidade de créditos, de empréstimos para a compra de terrenos, de mudanças no sistema financeiro para a habitação, seja publico ou privado. O movimento de financeirização que se situa atualmente de maneira significativa na "remuneração" do capital perpassa também a condição de referência para o preço da terra em geral, uma vez que a reprodução contemporânea se dá pela inserção do espaço na financeirização e nas formas de remuneração do capital. Dessa maneira, os preços do mercado de terras se condicionam, além da própria localização e estruturas ali dispostas, à remuneração dos juros do mercado de crédito em geral. Quanto mais estes se associam à economia geral e perpassam o espaço como fonte de remuneração e referencial para as transações correntes, mais se tornam definidores dos preços no mercado de terras.

A metropolização foi se constituindo de momentos que revelavam a condição centro-periferia como afirmação-negação do urbano para outras formulações a respeito desse processo. Nos termos atuais, cabe retrabalhar esta contradição, o que implica uma análise pressuposta pelo espaço fragmentado no qual a reprodução passa não só a produzir o negativo, mas a afirma-lo, ou seja, alçar a periferia à condição espacial de territorialização das novas formas de reprodução que se apresentam enquanto realização do capital em geral e de sua forma financeira de maneira primordial, a financeirização do espaço. No entanto, o faz sem pressupor uma positividade, pois ao se financeirizar no espaço urbano, em seus fragmentos como aqueles considerados periféricos, o faz sem necessariamente incorporar aos moradores desses espaços, ou seja, aprofunda as relações negativas pressupostas para a

\footnotetext{
${ }^{69}$ Para Paulo C. X. PEREIRA trata-se de uma "reestruturação imobiliária" (PEREIRA, 2005).

${ }^{70} \mathrm{O}$ trabalho de Teresa P. R. Caldeira faz um apanhado histórico da metropolização em São Paulo a partir do que a autora considera como os "três padrões de segregação espacial" desse processo. Ver CALDEIRA, 2000 pp. 211-256.
} 
definição de "urbano periférico" e, como resultado, requer para essas novas condições que os moradores das áreas de investimento, ou grande parte deles, sejam removidos, ou melhor, a negatividade da negatividade é a expropriação, a metropolização é antitética.

A noção de "urbano periférico" (BURGOS, 2008) situa na contemporaneidade a fragmentação da metrópole diante das novas condições de reprodução, definidas tanto pela reprodução da pobreza em diferentes espaços, como pelas possibilidades para que esta se torne, de modo diferenciado, viável ao processo de acumulação.

Portanto, se existiu um determinado momento do processo de urbanização no qual a formação espacial da periferia urbana coincidiu com os conteúdos sociais da reprodução da classe trabalhadora, sob o padrão de desenvolvimento periférico, parece que estamos na atualidade lidando com outro tempo. As mudanças no mundo do trabalho redefinem o lugar da classe trabalhadora no processo de modernização social, tornando-se, sob muitos aspectos, desnecessária aos processos produtivos, sobretudo os mais desenvolvidos. Por sua vez, estas mudanças sociais se traduzem como transformações recentes das periferias da metrópole, na qual se instauram territórios, tanto para as estratégias de sobrevivência dos pobres urbanos na condição de sobrantes, quanto para a formação, acumulação e expansão do capital (BURGOS, 2008 p. 37/38).

Assim como as necessidades do capital vão se situar naquilo que é a periferia, esta também se situa naquilo que se define como centro. Rosalina Burgos analisa tal contradição como interna ao urbano mesmo, forma-conteúdo que redefine as condições anteriores:

[...] se por um lado, o urbano enquanto negatividade é mais completo na periferia (o que é a própria periferia), por outro o déficit de negatividade maior no centro, não chega ao ponto de permitir a positividade plena do urbano; positivo-negativo ficam em conflito. Essas reflexões conduzem ao urbano periférico. (Idem, p. 41).

A condição atual de que a periferia está no centro remete também ao seu contrário, pois o capital se vale de novos espaços antes considerados como as distantes periferias para as condições de sua realização. O processo da metrópole como condição espacial da reprodução do capital se põe em novos termos ao dispor de sua própria produção histórica, o espaço da metrópole profundamente fragmentado pelas formas de reprodução capitalista. 
Como conteúdo dessas outras relações, o urbano se constitui sob novas contradições.

Uma significativa leitura desses novos tempos, porque não de novos espaços, nos é apresentada por Amélia Damiani:

As grandes cidades, as metrópoles, centralidades nucleares de todo o processo, definem uma população gigantesca, sobrevivendo mediocremente de uma história em migalhas. $\mathrm{E}$ aqui não são abordados somente os desempregados e subempregados; a essa massa acrescenta-se uma burguesia perdida no consumo voraz do nada e no nada do consumo. Em todas as classes sociais não se reconhece a consumação: o perder-se no prazer sem limites, sem hora e lugar certos, o puro gozo. Alinhavam-se fragmentos de vida no mundo da sobrevivência de todo o tipo (DAMIANI, 2004 p. 38).

De qualquer maneira, é necessário pensar na fragmentação da metrópole não como um processo que somente separa, mas que precisa ser entendido na e pela relação necessária entre seus fragmentos, pois centro e periferia se condicionam pela relação negativa que os une, pelas formas que a divisão do trabalho os dispõe enquanto realização da reprodução, das imprescindíveis condições de relacionar trabalho morto e trabalho vivo.

É trágico notar que o que anima a metrópole é a própria negatividade que se espraia como vida cotidiana de seus moradores, condição espacial que o urbano sustenta sob as sucessivas transformações a partir de sua realização histórica de abrigar o capitalismo e suas esferas reprodutivas a perpassar diferentes momentos dessa reprodução, pois as condições históricas produzidas na metropolização de São Paulo conformaram vastos territórios empobrecidos, mas este empobrecimento não se pode associar somente às carências materiais, e sim que estes estão conformados no interior de um cotidiano ausente de inúmeras possibilidades, ausência mesmo de subjetividades, ou a busca às conformações sociais pelo acesso à objetivação material enquanto realização subjetiva.

Tal condição é histórica e conjugada aos elementos definidores do cotidiano e que tornam-se instrumentais, para as quais as médias sociais, ou mesmo as mínimas dentro destas, bastam para as definições políticas e da produção do espaço:

O espaço da vida cotidiana, mesmo num país como o nosso, amplia a noção de pobreza urbana, para além dos bolsões de pobreza absoluta, mesmo o considerado como uma utopia de 
massas enormes de empobrecidos moradores de favelas, cortiços, cantos de rua, indigentes que aspiram uma vida organizada e uma casa segura [...] numa leitura funcional dos desejos humanos (DAMIANI, 1993, p. 33-4).

O que se revela neste contexto é a metrópole sob os processos constitutivos da reprodução do capital no mundo contemporâneo como simultaneidade, cuja fragmentação é resultado e processo ao mesmo tempo. Diante da constituição histórica das relações de produção na sociedade capitalista, a divisão do trabalho se põe como processo que fragmenta e une ao mesmo tempo. À divisão centro-periferia pressuposta nas décadas anteriores como necessidade da acumulação de capital se impõe outra, posta na atualidade por uma distinção morfológica, indistinta em termos de investimento de capital com vistas à reprodução, sobretudo a partir da esfera financeira. "Indistinta", pois, pela transposição de uma relação anterior centroperiferia, situada na contemporaneidade numa unidade fragmentada que é a metrópole em si. No entanto, considera-se seus fragmentos como momentos necessários a essa reprodução a partir de contradições internas que estes pressupõem.

As periferias foram constituídas historicamente como local de reprodução da força de trabalho, um momento necessário da divisão do trabalho explicada pela definição do duplo processo urbanizaçãoindustrialização na metropolização de São Paulo. Interessam, na atualidade, as novas condições de reprodução do capital como financeirização dos lugares, como produção do espaço urbano que resulta em investimentos, em territorialização de significativas massas de capital na forma de estruturas urbanas as mais variadas, objetivadas pelo trabalho e suas condições cada vez mais precárias. Para essas novas condições, trabalho vivo e morto se combinam, mas há outros pressupostos. As estruturas fixadas aos lugares, ou em vias de, tais como vias expressas, linhas de trem e metrô, novas modalidades como os monotrilhos, enfim, estas continuam a explicar a lógica da divisão territorial do trabalho, mas incorporam também outra lógica que é a da territorialização financeira, esta que "varre" o trabalho morto ali constituído para repor os termos da reprodução. Nas últimas décadas na metrópole paulistana são muitos os exemplos de terra arrasada, todo o trabalho objetivado nos lugares de interesse para os investimentos financeiros vem 
abaixo. Há então um significado novo para a divisão do trabalho, pois esta ainda considera o espaço como concreto ao mesmo tempo em que ganha cada vez mais o significado abstrato, o espaço em si, quase puro, para o qual o trabalho morto quase nada significa, pode morrer de vez e ser enterrada sua concretude para que sobre o pó das coisas surja o novo.

Se define uma condição espacial, socioespacial melhor dizendo, significativa para se pensar as relações entre o espaço e o capital, que é a constituição e a instituição da propriedade privada na metrópole posta e disposta como forma reconhecida e "naturalizada", processo elementar no interior do qual se debatem, seja como constituição ou instituição, propriedade e a não-propriedade, produto histórico pressuposto pela intitucionalização do espaço, pelas formas de reprodução da força de trabalho, seja nos chamados loteamentos clandestinos ou nas favelas, ou ainda nos projetos institucionais do Poder Público. As atuais condições de financeirização do espaço abarcam essa produção espacial histórica e definem de que maneira tais e tais populações se inserem nessa lógica, seja pela integração ou pela expropriação.

A separação acarreta a separação da população em classes e não pode existir senão no quadro da propriedade privada do solo e do dinheiro, tomando a última o lugar da primeira como poder dominante. Que resulta daí? A alienação Geral (LEFEBVRE, 1972, p. 51).

A metropolização de São Paulo, desde seus primórdios, se fez a partir de ordenamentos territoriais os quais serviram a grupos sociais dominantes, ao mesmo tempo em que definiam espacialmente os territórios das populações empobrecidas. Os diferentes momentos desse ordenamento socioespacial resultaram numa segregação como conteúdo histórico da metropolização. Como resultado, uma porção significativa do espaço metropolitano se fez, do ponto de vista jurídico, de maneira "irregular". São os chamados "loteamentos clandestinos" e as ocupações, processos definidos no interior da própria metropolização, como conteúdo desta. $\mathrm{Na}$ atualidade, diversas ações de reordenamento do espaço acontecem justamente nessas áreas, espaços empobrecidos e, como fundamento efetivo destas ações, sem propriedade jurídica da moradia, ao menos na grande maioria dos casos. Sob a definição de áreas de risco ou de proteção dos atributos ambientais, em certos casos 
ambas as justificativas, tais espaços passam a compor novas definições jurídicas no sentido da remoção das moradias e do estabelecimento de zonas de preservação ambiental. São os nexos da relação capital-espaço. No entanto, compõem-se de elementos estruturais relacionados à dinâmica da reprodução.

A tentativa de se chegar ao espaço como condição do capital nos remete a pensar de que maneiras tal condição se realiza. Uma primeira reflexão nos leva a pensar no espaço como condição do capital fixo sob as premissas da divisão do trabalho como organização do processo produtivo, realização da mais-valia. Por outro lado, trata-se de novos nexos que relacionam os capitais envolvidos na esfera financeira, assim como produção de espaços implicados pela lógica do tempo-livre, como espaços de consumo relacionados à mercadoria tempo, cada vez mais presentes no mundo contemporâneo. Percebe-se desde há décadas que os mecanismos financeiros dispostos à produção do espaço realizam-se principalmente como estruturas voltadas para as formas de uso do tempo como tempo-livre, como extensão do tempo de trabalho, como consumo do tempo, como tempo de consumo:

Tempo livre é uma categoria da modernidade que se insere funcionalmente no tempo produtivo da sociedade do trabalho. Tanto que tem dado margem a que se desenvolva a indústria do entretenimento. Atualmente é a indústria que mais cresce, da qual o turismo é a maior expressão, e na qual o futebol se insere como atividade superorganizada, organizada inclusive em nível global, movendo multidões em direção aos estádios em todo o mundo (SEABRA, 2008 p. 135).

A atualidade das formas de produção do espaço destinadas ao uso do tempo livre revelam os rearranjos contemporâneos da reprodução e suas categorias, o trabalho, a divisão do trabalho, a propriedade, enfim as novas combinações estruturais que implicam o espaço no interior da reprodução. Em nossa área de estudo, Zona Leste da cidade de São Paulo, foi construído o estádio de futebol apelidado de Itaquerão, a Arena Corinthians, a qual foi uma das sedes de algumas partidas da Copa do Mundo de 2014 no Brasil, inclusive da partida de abertura deste evento. O futebol torna-se ao longo de sua trajetória um negócio mundial a partir do qual se estruturam formas de territorialização do capital, tal como a construção dos estádios pelo Brasil com vistas à realização das partidas deste evento mundial, assim como as 
infraestruturas para que o evento aconteça. Tais formas de produção do espaço se produzem para o consumo do tempo-livre, transformar este em tempo de consumo.

Tal exemplo expõe também o espaço como virtualidade, o qual se predispõe historicamente como reserva territorial, espaço acumulado, o qual, na atualidade, se dispõe à realização de diversos interesses como são os ligados às transformações objetivas na Zona Leste de São Paulo em virtude da Copa de 2014. Em seu trabalho sobre as moradias institucionais da Zona Leste, Amélia Damiani já verificava a repartição das terras do Poder Público Municipal em diferentes modalidades, dentre elas, o terreno destinado ao Corinthians para a construção do "futuro" estádio de futebol:

Outras destinações impostas pelo poder municipal enquanto áreas com finalidades institucionais de interesse social, reduziram a área original do projeto Itaquera I [...] área reservada à Prefeitura do Município de São Paulo, equivalente a 197095,14 $\mathrm{m}^{2}$, com finalidades esportivas. Em princípio cedida ao Corinthians Paulista para a construção de um estádio na Zona Leste. (DAMIANI, 1993 p. 107).

Reservada durante muitos anos, essa massa de terra ganha definitivamente a sua condição como realização do capital quase três décadas depois (cedida ao Corinthians ainda na década de 1980), inclusive no interior de um processo de transformação de todo o espaço nos arredores, em função das possibilidades de incorporar à terra os efeitos do trabalho social proporcionados pela construção do estádio. O próprio conjunto habitacional de Itaquera passa por um processo de "valorização" proporcionado pelas transformações daquele espaço, o que resulta também em remoções de populações empobrecidas dos arredores, como é o caso da Favela da Paz.

Estamos diante das metamorfoses das formas urbanas pressupostas pelo capital, as quais, em momentos anteriores eram explicadas, sobretudo pelas estruturas que dinamizavam o tempo de trabalho, estruturas que serviam à circulação física da forma mercadoria sob a condição de produto e força de trabalho. Claro que tais condições não desapareceram e que, inclusive, se mostram combinadas, como é o caso das construções dos estádios para a Copa do Mundo de 2014 no Brasil, evento que expõe a exploração extensiva do trabalho produtivo, mas que se combina com as formas de realização predispostas ao tempo-livre e ganham a dimensão objetiva a partir de grandes 
investimentos oriundos da esfera financeira. Claro está que forma e conteúdo se imbricam num processo que se realiza pela conformação entre tempos e espaços:

A esse espaço, cujas "propriedades" situam-se na articulação da forma e do conteúdo, corresponde um tempo que tem as mesmas "propriedades". O tempo, bem supremo, mercadoria suprema, se vende e se compra: tempo de trabalho, tempo de consumo, de lazer, de percurso, etc. Ele se organiza em função do trabalho produtivo e da reprodução das relações de produção na cotidianidade. O tempo "perdido" não o é para todo mundo, pois é preciso pagar caro por ele. O pretenso "tempo livre" é apenas o tempo separado e mantido como tal nos quadros gerais. Quanto ao tempo imposto, aquele dos transportes e das formalidades, já se sabe como ele se vincula de maneira deslocada ao tempo de trabalho (LEFEBVRE, 2008 p. 50).

O espaço das periferias, constituído historicamente por formas de inserção da força de trabalho ao processo produtivo, ao mesmo tempo em que se realizava como negação ao urbano para estas mesmas populações, se dispõe agora a outras formas de realização do capital, se dispõe à financeirização, que há de anima-lo e varrê-lo na produção de novas estruturas urbanas na qualidade de investimentos realizados pelo conjunto das instituições públicas e privadas a partir dos inúmeros projetos urbanísticos, proposições estatais de produção do espaço metropolitano.

[...] o setor imobiliário vê-se subordinado ao grande capitalista, ocupado pelos empreendimentos capitalistas (industriais, comerciais, bancários) e com a sua rentabilidade cuidadosamente manipulada a coberto do reordenamento territorial. O processo que subordina as forças produtivas ao capitalismo repete-se aqui, tendo em vista a subordinação do espaço lançado no mercado ao investimento de capitais, ou seja, simultaneamente ao lucro e à re-produção das relações de produção capitalistas (LEFEBVRE, 1972 p.155).

A financeirização acontece sob a ordem estatal e por esta se realiza fundamentalmente como dívida pública, como papéis financeiros dispostos mundialmente na forma de títulos de dívidas negociados no mercado financeiro mundial, a lógica que vai se tornando majoritária e que, por seu movimento interno, quanto mais se consome, mais aumenta e, em seu apetite, consome aquilo que se dispõe pela lógica mercantil. $O$ espaço torna-se primordial neste processo, ao mesmo tempo em que as relações socioespaciais se redefinem. 
Esse novo momento da metropolização que denominamos antitética é a afirmação do capital como reprodução do espaço e a negação deste aos moradores das áreas a serem financeirizadas, do espaço como condição objetiva do capital e, por via dos processos contemporâneos, da financeirização dos lugares como pressuposto das novas condições da reprodução, e que desta relação deriva a produção do espaço.

No entanto, do que se trata a produção do espaço? Do espaço em si? Sim e não, pois não é forma pura. Em seu interior é conflito que envolve outras estratégias cujas tramas se combinam às novas formas de organização social, no emaranhado disforme que confunde-se em relações postas e impostas na cotidianidade. São formulações que se constituem no interior das tramas políticas as quais envolvem e revolvem o cotidiano, os elementos jurídicos, as formas de organização social, enfim:

Qual é o estatuto teórico da noção de espaço? Qual é a relação entre espaço mental (percebido, concebido, representado) e o espaço social (construído, produzido, projetado, portanto, notadamente o espaço urbano), isto é, entre o espaço da representação e a representação do espaço? (LEFEBVRE, 2008 p. 40).

Os pressupostos dessa formulação perpassam relações subjetivas, buscam-nas no sentido de internalizar a ordem social vigente posta pela necessidade da reprodução contemporânea. Os discursos aqui ocultam as estratégias de produção do espaço e se realizam no campo da luta corporal, o corpo todo, objetivo, subjetivo, concreto, abstrato, realidade, fantasia. Um campo de forças que, embora desigual, procura afirmar-se como realidade social para ser aceito no maior âmbito social possível. Não basta remover 0 corpo daquele espaço, suas vestes, seu abrigo. É preciso removê-lo do campo de luta, revolvê-lo na subjetividade, predispô-lo ao discurso. Trata-se das formulações contemporâneas da produção do espaço não como realização somente num plano superior e vertical, mas que se define num campo de luta travada no cotidiano. O Pantanal da Zona Leste de São Paulo é um momento desse conflito, situação que revela diferentes formas pelas quais se move a reprodução capitalista contemporânea, o espaço e sua singular condição para essa reprodução, o tempo como objeto de consumo, a financeirização como processo intrínseco da reprodução, as ideologias e práticas como 0 
ambientalismo e a sociedade do risco e as formas reificadas da natureza predispostas como objetos reais e ao mesmo tempo como abstrações, uma vez que as planícies fluviais do rio Tiete na referida área incorporam o positivo e o negativo desse processo, o qual se aproveita para mover-se nelas e por elas. 


\section{Capítulo VII}

\section{Rios e Várzeas na Metropolização de São Paulo}

A apropriação dos rios e das várzeas da Bacia Sedimentar de São Paulo reflete a própria metropolização. Seus conteúdos históricos foram definidos da mesma maneira que a modernização incorporou os elementos da natureza originária como forças produtivas sociais. Mas, o fez sob contradições que afirmam a natureza como primordial e necessária para negá-la como força produtiva. Torna-se outra natureza, natural e social ao mesmo tempo, positiva e negativa como relação. Esse propósito nos interessa primeiramente porque esclarece a produção do espaço a partir de uma substância original, natural, mas apropriada e transformada por relações sociais constituídas historicamente. Por outro lado, nos permite entender que a transformação dessa natureza originária pode servir numa sociedade de classes a interesses no sentido tanto de modifica-la como de manipulá-la. Torna-se uma substância política. É uma natureza que se expressa como natural, por sua corporeidade, em certa medida, intangível; mas que incorpora relações sociais uma vez que essa materialidade se constitui no seio destas. Tais relações estão no centro do conflito entre moradores e instituições no Pantanal da Zona Leste e é necessário compreender essa história para desfazer a cortina de fumaça que se interpõe à análise.

Partimos dessa relação sociedade-natureza como uma relação transformadora para ambas as partes. Marx e Engels (2007) fazem uma construção dos processos sociais que identificam e ao mesmo tempo separam os indivíduos na sociedade a partir da divisão do trabalho como uma construção histórica do modo social de produzir os elementos materiais assim como a própria consciência dos indivíduos. A primeira condição inseparável da constituição histórica do ser social é a natureza em si como fundamento da base estrutural da vida em sociedade, cuja produção se define na mediação com esta pelo conjunto da sociedade, cujo trabalho se desenvolve socialmente, em cooperação. Conforme estes autores, não é possível opor história e natureza, há uma "história natural e uma natureza histórica" (idem, p. 31) que 
se desenvolvem a partir da indústria, não a fábrica em si, mas a condição dos grupos sociais de se proverem de meios materiais:

[...] o primeiro ato histórico é pois a produção dos meios para a satisfação dessas necessidades, a produção da própria vida material, e este é, sem dúvida, um ato histórico, uma condição fundamental de toda a humanidade [...]" (idem, p.35).

Como dito acima, a apropriação da natureza é histórica, se produz de acordo com as relações de produção e forças produtivas estabelecidas naquele momento. Portanto, produz também consciência, a práxis:

Antes de tudo, o trabalho é um processo entre o homem e a Natureza, um processo em que o homem, por sua própria ação media, regula e controla seu metabolismo com a Natureza. Ele mesmo se defronta com a matéria natural como uma força natural. Ele põe em movimento as forças naturais pertencentes à sua corporalidade, braços e pernas, cabeça e mão, a fim de apropriar-se da matéria natural numa forma útil para sua própria vida. Ao atuar, por meio desse movimento sobre a Natureza externa a ele e ao modificá-la, ele modifica, ao mesmo tempo, sua própria natureza. (MARX, 1988 p. 142).

Essa necessária leitura é conflituosa, mas integradora ao mesmo tempo. Não se pode revelar o processo social aqui analisado separado da materialização social a partir dessa substância. Como nos propõe Henri Lefebvre:

O que é "substância" no sentido filosófico? É natureza metafisicamente dissimulada quando separada do homem. Inversamente, o que é consciência? É o espírito humano metafisicamente dissimulado quando separado da natureza (LEFEBVRE, 1980, p. 177).

Consciência é uma natureza humana ou se desenvolve como processo social? A mediação produz e é produzida pela consciência. Na comparação entre o trabalho como instinto natural e o trabalho social, Marx pressupõe a incomparável precisão na construção de um favo pela abelha relativamente a um arquiteto. No entanto, uma diferenciação ao mesmo tempo ontológica e natural os separa: "Mas o que distingue, de antemão, o pior arquiteto da melhor abelha é que ele (o arquiteto) construiu o favo em sua cabeça antes de construí-lo em cera" (MARX, 1988 p. 142). O humano é uma construção que perpassa a consciência como processo estrutural, ou seja, a práxis passa pela cognição. A corporeidade, o movimento, a percepção, tudo isso é abstração como processo intrínseco que perpassa aquilo que vem de fora, que lhe é 
externo. A corporeidade é uma condição indistinta da vida. A distinção como condição humana, conforme Paulo Freire, é a "transcendência", a apreensão da "finitude", da "temporalidade", de "objetivar-se e reconhecer órbitas existenciais diferentes" (FREIRE, 1971 p. 29) ${ }^{71}$. Para Vygotsky esse humano se apresenta como físico, um processo evolutivo a partir do qual se desenvolvem qualidades objetivas da humanidade (filogênese), mas essa condição física não se separa daquilo que se desenvolve internamente, na consciência, no saber, na possibilidade da abstração e da transcendência (ontogênese); um desenvolvimento interno e externo a partir de corporeidade como processo físico e social. Práxis é então interna e externa, corpo e consciência, individual e social. Neste e por este movimento entre consciência e corpo que relaciona a apropriação social da natureza pelo trabalho social é que se constituem historicamente as formas objetivas e subjetivas que relacionam consciência e ação. Dessa maneira, como processo histórico, a subjetivação se desenvolve também como processo político. A biopolítica é a face objetiva desse processo. De certa maneira, as lógicas sociais não se separam da forma política e se fazem compreender a partir dessa como razão social. Por estes meandros se constroem as representações como objetivações sociais, a "consciência mistificada" da qual nos fala Henri Lefebvre (2008).

Nessa história em que a sociedade transforma e é transformada pela relação com a natureza mediada pelo trabalho, surgem elementos da própria natureza social como processo histórico definido pela relação com a natureza originária. Dessa forma, as mesmas representações sociais que turvam os elementos da produção do espaço urbano recaem na produção do espaço urbano enquanto apropriação social da natureza.

Para o caso de São Paulo e sua particular formação geomorfológica, o ambiente fluvial das várzeas se efetiva como possibilidade para os projetos financiados por agências internacionais ancorados nos termos da sustentabilidade. A condição histórica de "apropriação" tanto estatal como privada deste ambiente se mostra ao longo de toda a metropolização de São Paulo como processo político que se define pela expropriação. Odette Seabra

\footnotetext{
${ }^{71}$ Jorge Luis Borges nos brinda com a compreensão da transcendência, da temporalidade humana no conto O Imortal: "Ser imortal é insignificante; salvo o homem, todas as criaturas o são, pois ignoram a morte; o divino, o terrível, o incompreensível é saber-se imortal". Jorge Luis BORGES: Nova Antologia Pessoal. Rio de Janeiro: Ed. Sabiá, 1969.
} 
nos fala das metamorfoses nas formas de uso do tempo como elementares na compreensão da modernização, e de como, neste processo, foram se expropriando os usos ligados aos rios e às várzeas para assumirem estas a condição de forças produtivas na metrópole de São Paulo ${ }^{72}$.

A história da apropriação urbana dos rios e das várzeas na Bacia Sedimentar de São Paulo perpassa mais de um século e insere diferentes grupos sociais nas tramas políticas as quais envolvem o Estado e grupos privados que, sob diversos aspectos, tornaram-se possibilidades de realização de variados e obscuros negócios urbanos. Como revelou Odette Seabra (1987) em sua tese de doutorado, são "os meandros dos rios nos meandros do poder" 73 .

Desde os tempos imemoriais, os rios e várzeas se constituíram em importantes recursos para o processo social em São Paulo. Conforme Caio Prado Junior:

[...] por ser o centro natural do sistema hidrográfico da região. Sem o saberem, seus fundadores tinham-no estabelecido num ponto donde irradiam em quase todas as direções, ou pelo menos as principais, estas vias naturais de comunicação que são os cursos d'água. (PRADO JR, 1983 (1943), p. 20).

Como vias de deslocamento, como referências para as vias terrestres ${ }^{74}$, os rios paulistanos foram incorporados material e simbolicamente nas condições da sociabilidade que adentraram o século $X X$. Basta verificar as toponímias que pontilham até hoje os lugares da metrópole e revelam tanto a rede hidrográfica como as formas de relevo, vales e planícies, não somente nomeadas como referência e localização, mas principalmente por sua dinâmica, pelas relações que indicam a interação dos elementos e fatores naturais revelados pela denominação conceitual que insere a compreensão social na leitura e na apropriação do ambiente natural: Itaquera, Ibirapuera, Tamanduateí, Tietê, Anhangabaú, Jurubatuba, Jaguaré, Ipiranga,

\footnotetext{
${ }^{72}$ SEABRA, 2008 p. $129-146$.

${ }^{73}$ Esta frase dá nome à tese de Odette Seabra a qual revela de que maneira a Cia. LIGHT se apropriou privadamente das terras no entorno do rio Pinheiros e realizou, via expropriação, um processo de formação de capital ao relacionar as contingencias do ambiente fluvial das várzeas com possibilidades políticas da manipulação das estruturas técnicas sob sua concessão na Bacia do Alto Tietê (SEABRA, 1987, op. Cit.).

${ }^{74}$ Ver capítulo "A história dos caminhos nos caminhos da Historia" in SILVA, 2009.
} 
Paranapiacaba, Mogi Guaçu, Itaquaquecetuba, Carapicuíba, Pirajuçara, Piratininga, Barueri, Parnaíba, Morumbi, e por aí vai.

Mais do que simples nomes, revelavam a dinâmica dos ciclos e interações que compõem a paisagem. Desse modo, o nomear nunca se antepunha ao sentir, ao se apropriar, e expressava a leitura de um processo dinâmico que conduziu e foi conduzido por povos originais e, por mais de trezentos anos, também por outros aqui chegados ou aqui feitos $\mathrm{e}$ desenvolvidos pela mistura, pela violência, pelos rearranjos e interações do "povo que come farinha de pau"75, uma identidade desidentificada e ao mesmo tempo assumida como condição histórica e social de um complexo sistema que resultou em grupos sociais mais ou menos primordiais definidos por uma espacialidade colonial nuclear e rarefeita, cujos lugares ganharão novos nomes e significados ao longo da modernização.

Por este mesmo processo que se redefinem tanto os grupos sociais como os lugares, movidos por lógicas destitutivas das qualidades prementes e de certa forma originárias para metamorfosearem-se noutras predispostas e reveladoras da inserção na modernidade, sobretudo no século $X X$, processos transitórios definidos pela relação contraditória entre o rural e 0 urbano. Peixeiros, oleiros, cascalheiros, areeiros, agricultores de vazante, grupos sociais definidos por sua interação com os rios e as várzeas em São Paulo mantinham e propugnavam saberes sobre esses elementos da natureza originária e difundiam um modo de vida ligado e definido por essa relação com os ambientes fluviais. Por outro lado, tais práticas compunham cada vez mais o campo das relações mercantis predispostas pela urbanização, processo que explicava os arredores rurais de São Paulo cada vez mais pela relação contraditória com a cidade, tal como nos apresenta esta passagem da obra de Aziz Ab'Saber:

Em seus terrenos mais firmes, as várzeas asilaram grandes chácaras, de aparência pobre, e humildes moradias de trabalhadores que viviam do rio ou da própria terra varzeana. Proliferaram, desta forma, por toda a sua extensão as olarias

75 Darcy Ribeiro reconstrói elementos dessa constituição do povo a partir daquilo que denomina "protocelulaneobrasileira", formação estrutural étnica que identifica essa nova formação populacional e, pela identidade que comunica o imemorial ao novo, o ritual e o simbólico realizados na prática comum, a comunhão do alimento que congrega o sofrimento e a redenção, a farinha de pau, o comum de dominantes e dominados (Darcy RIBEIRO: O Povo Brasileiro. São Paulo: Brasiliense, 1994). 
que ajudaram a construir a cidade. Portos de areia e cascalho pontilharam 0 dorso dos diques marginais dos rios, contribuindo com a porcentagem mais importante dos materiais de construção, que aos poucos foram empilhados nos arranhacéus da metrópole. (AB'SABER, 1957 p.155).

O devir, a metropolização e a condição de transformação dos rios e várzeas em forças produtivas da sociedade, já posta no momento acima, define por vez a supressão de tais modos de vida por uma relação contraditória com os ambientes fluviais pautada nas necessidades daquilo que é considerado urbano do ponto de vista estrutural. Afirmar o ambiente fluvial dos rios e das várzeas tornou-se o pressuposto de sua negação enquanto processo urbano. Terrenos hidromórficos e alagadiços, criadouros de mosquitos, despejo dos dejetos sociais, ambientes fétidos, terrenos baldios, "terra de ninguém". Tudo isso afirmava rios e várzeas por sua condição natural predisposta aos usos sociais para que fossem transformadas pela negação dessa mesma condição naquilo que era o outro de tudo isso, canais confinados, cobertos, terrenos saneados, planos, vastos e dispostos aos loteamentos (pois que as terras de ninguém eram ou se tornariam propriedade privada), urbanizados principalmente no sentido da circulação viária, sobre os quais seria montado ao longo da metropolização um sistema viário de fundo de vale de nível metropolitano.

Em fins do século XIX grandes transformações no espaço urbano em São Paulo passam a se materializar em elementos da modernização como foi a substituição de diversas formas de energia, por exemplo, carvão, tração animal, pela energia elétrica. Acompanhando o próprio desenvolvimento das relações de produção, se consolida em São Paulo formas mundiais pelas quais tais transformações operam. É o caso dos serviços urbanos oferecidos por trustes internacionais contratados sob regime de concessões. O sistema hidrotécnico do Alto Tietê produzido ao longo da metropolização de São Paulo teve sua montagem com a estruturação do sistema de produção de energia hidrelétrica no período de concessão de serviços de energia e transporte para a Cia. LIGHT S/A. Embora oriundo de um passado em que a produção de energia no Alto Tietê tinha significado, tal sistema permanece objetivado num trabalho morto, num capital fixo que não se sabe exatamente como ou se se realizou, mas que transformou definitivamente todo o processo hidrológico da 
Bacia do Alto Tietê, configurando uma das obras de engenharia mais emblemáticas, como foi a reversão do rio Pinheiros, a construção de barragens, usinas elevatórias, transposições de rios, enfim, todo um sistema técnico de sofisticada engenharia para a produção de energia.

Conforme o relato da Professora Odette Seabra, resultado de suas pesquisas a partir de sua Tese de Doutorado, as modificações provocadas por este sistema são de tal magnitude que não se pode mais considerar um sistema de drenagem do Alto Tietê a partir de suas premissas naturais, mas a partir da consideração das transformações ocorridas com a montagem do sistema Light $^{76}$. E dentro deste sistema opera de maneira contundente um conjunto de barragens responsável por parte significativa da vazão do rio Tietê, inclusive de maneira segmentada a partir da operação da barragem da Penha (ver Apêndice - Mapa I), que "separa" o trecho do rio percorrido pelas vias Marginais do trecho à montante, que corresponde à Zona Leste da cidade de São Paulo e se estende para outros municípios da Região Metropolitana, tais como Guarulhos e Itaquaquecetuba. Tal sistema já havia sido manipulado antes com vistas à formação e reprodução de capital ao expropriarem tanto o trabalho como a terra (ver Capítulo I: A Produção Desigual do Espaço). Soa estranho uma objetivação técnica usada para tais fins. No entanto, tais estruturas se afirmam como conteúdo técnico do processo político, tal como descrito no Capítulo II.

Sem dúvida, um dos elementos estruturadores da apropriação urbana dos rios e das várzeas foi a própria urbanização, na forma de canalizações, retificações, aprofundamento de leitos, transposições, construções de barragens, produção de energia, construção de avenidas de fundo de vale, enfim, uma produção técnica com a finalidade de realização destes ambientes naturais como forças produtivas na metropolização de São Paulo. Mais do que isso, tais formas se referem a conteúdos dentro do processo social, os quais se definem como apropriação do trabalho social pela condição da propriedade privada. As diferentes formas de valorização oriundas da urbanização dos ambientes fluviais proporcionaram, a partir da remuneração da propriedade privada do solo urbano, mecanismos de captação de porções do trabalho social

76 Palestra proferida pela professora Odette Seabra no encerramento do II Simpósio Internacional de Eletrificação e Modernização, no dia 29 de maio de 2013 
que propiciaram negócios urbanos os mais variados baseados nas condições estruturais daquela urbanização:

A consecução do sistema viário, cujas obras coincidiram com as da retificação (do rio Pinheiros), sobre-valorizaram os terrenos que, ao invés das indústrias (como no rio Tietê), possibilitaram a localização de atividades terciárias. [...] A articulação das marginais ao restante da metrópole (e por que não dizer do país) na forma de vias de circulação rápida e intensa favoreceu diversas atividades como os supermercados (SEABRA, 1987 p.7).

A condição espacial do solo urbano corresponde à situação relativa de suas formas, das intervenções urbanas, jurídicas e políticas, do processo social em si e de sua condição enquanto apropriação por parte de grupos sociais, cujo espaço é delimitado por um processo histórico no interior do qual tais situações se definem como lógicas da mercantilização:

A valorização das várzeas não se explica por si mesma. É no contexto de um processo de diferenciação e de divisão do trabalho em geral, através do qual foi se definindo o que seria propriamente urbano, em oposição ao rural, que encontramos sua gênese (da valorização). (idem, p. 13).

A urbanização dos ambientes fluviais resultou não somente numa diferenciação dos lugares de acordo com o trabalho social objetivado e das condições deste ser incorporado aos rendimentos da propriedade privada da terra, mas também num processo de urbanização como um sistema, uma lógica definida pela circulação dentro do modelo viário-automotivo, para o qual o ambiente fluvial foi fundamental. Já em fins do século XIX, as intervenções urbanas nos rios e várzeas proporcionavam a canalização e a retificação dos rios concomitante à construção de avenidas de fundo de vale, conforme nos lembrou Odette Seabra nas citações anteriores, que resultou numa lógica de circulação viária que ao longo dos anos se constituiu num grande sistema que relaciona esta à rede hidrográfica ${ }^{77}$.

Diversos foram os momentos dessa montagem sistêmica da circulação viária, cujos referenciais podem ser encontrados ainda no século XIX. No

${ }^{77}$ Em minha Dissertação de Mestrado, corroboro com as formulações de Odette Seabra, a partir das quais foi possível desvendar as diferentes políticas públicas, assim como suas estratégias, na definição dessa forma, a correspondência entre rede hidrografia e sistema viário no interior da metropolização. Ver SILVA, 2009. 
entanto, algumas políticas passam a compor o concebido ${ }^{78}$ de maneira sistemática para tais objetivações. Vale destacar o Plano de Avenidas do Prefeito Prestes Maia, da década de 1930, que lançou essa formulação urbanística no raciocínio do planejamento como devir de um processo que se modificaria em termos estruturais, mas que manteria sua substância por todo o século $\mathrm{XX}$, adentrando ao $\mathrm{XXI}$ com toda força, fato que questiona as crenças de que o crescimento urbano ocorre sem planejamento.

De maneira estratégica, a estruturação do sistema viário sobreposto à rede hidrográfica se relacionou à implantação de formas de financiamento oriundas da montagem de mecanismos internos para tais fins, como foi o caso da utilização dos fundos obtidos aos trabalhadores com registro em carteira (Fundo de Garantia de Tempo de Serviço - FGTS), resgatados pelo então Banco Nacional da Habitação (BNH) para fins de saneamento, ou melhor, canalização e retificação de rios e córregos situados em espaços urbanos.

\begin{abstract}
Vale lembrar que o instrumento que consolidou a diretriz de projeto de construir avenidas nos fundos de vale dos principais rios e córregos da capital foi o Plano de Avenidas de Prestes Maia. [...] Embora muitas dessas avenidas tenham sido projetadas nos anos 50, a maior parte delas foi executada nas décadas de 1980 e 1990, quando o poder municipal estabeleceu como estratégia conjugar as obras de canalizações de córregos à construção de avenidas, aproveitando a disponibilidade de recursos federais para as obras de saneamento básico. Esses recursos foram disponibilizados pelo governo federal para a realização de obras de saneamento básico nas grandes cidades brasileiras, como meta do Plano Nacional de Saneamento (PLANASA), através do Banco Nacional de Habitação (BNH). [...] Essas avenidas não tiveram origem em um plano viário, mas resultaram da lógica conduzida pelas obras de saneamento básico [...] (BIDERMAN, GROSTEIN \& MEYER, 2004 p 87).
\end{abstract}

Mais tarde, entram no jogo os capitais financeiros mundiais, com tais obras estruturais financiadas por grupos internacionais, como foi o caso do Programa de Canalização de Córregos e Construção de Avenidas de Fundo de Vale (PROCAV - Decreto Municipal 23440 de 16/02/87), lançado em fins da década de 1980 e cujas obras adentraram a década de 1990. Apesar de mudanças estruturais nas gestões municipais, este plano foi responsável pela

\footnotetext{
${ }^{78}$ Aqui o concebido tem um sentido "Lefebvriano", advém da politica que ao perpassar a lógica social aparece como necessário. Pressupõe o Estado como forma. Ver Odette SEABRA: A insurreição do uso; in Jose de Souza MARTINS (org.) Henri Lefebvre e o Retorno à Dialética. São Paulo: HUCITEC, 1996 pp. 71-86.
} 
integração de vários rios paulistanos ao sistema viário metropolitano, como foram os casos dos rios Jaguaré (Avenida Escola Politécnica), Pirajuçara (Avenida Eliseu de Almeida), Aricanduva (Avenida Aricanduva), Morro do S (Avenida Carlos Caldeira Filho), entre outros (Ver Apêndice: Mapa I).

Há nesse momento uma nova configuração para o financiamento dessas obras que combinam em seus projetos o ambiente fluvial com estruturas urbanas. A partir de então, relacionam-se formas internas de financiamento com mecanismos internacionais, já presentes no financiamento do PROCAV pelo Banco Interamericano de Desenvolvimento (BID), agora com projeto e financiamento específico. Este modelo seguirá condições predispostas pelos financiadores internacionais e, dentre os diversos focos para o financiamento, passa a situar-se como central a questão ambiental.

Também em fins da década de 1980, o Projeto Tietê é encaminhado para os órgãos internacionais de financiamento cujo foco era a despoluição do rio e de seus afluentes, justamente sob um forte apelo ambiental difundido pela mídia, com participação direta de grupos ligados às comunicações, como foi o caso da Radio Eldorado e do Jornal Estado de São Paulo (ambos do mesmo grupo), os quais apregoavam a boa nova ambiental para a população como condição primordial de civilidade e progresso, ou seja, sustentabilidade, pensar e agir para o futuro, afinal, algumas das grandes cidades do chamado mundo desenvolvido reverteram a condição de poluição dos seus rios, cujo caso emblemático é o de Londres com a despoluição do rio Tâmisa.

Algumas obras foram realizadas, como as Estações de Tratamento de Esgoto (ETE's); a tentativa (frustrada) de tratamento de esgoto nos rios por flotação, assim como obras de coletores para separação do escoamento fluvial e do esgoto ${ }^{79}$, além de um processo de médio prazo de implementação de formas de tratamento para esgotos industriais, cujas necessidades técnicas

\footnotetext{
${ }^{79}$ Em sua Dissertação, Nelcides M. de Souza revela o quanto o acréscimo de águas servidas à rede fluvial era interessante para o aumento da vazão dos rios do Alto Tietê, pois com esse acréscimo era possível, na maior parte do tempo, manter níveis de vazão suficientes para a produção de energia elétrica pela Cia. Light. Em dados momentos, principalmente no período seco, segundo o autor, a contribuição das águas servidas para a vazão total dos rios desta bacia era maior do que a própria vazão fluvial propriamente dita, o que mantinha níveis aceitáveis para a produção hidrelétrica. Ver Nelcides Marcondes de SOUZA - O esgoto como agente assoreador dos rios da RMSP, o estudo de caso dos rios Tietê e Pinheiros. São Paulo: Mestrado FFLCH, 1995.
} 
para tal compunham também o escopo do financiamento, ao disponibilizar créditos às empresas para instalar tecnologias de tratamento de águas servidas. Tudo isso resultou numa diminuição dos lançamentos de esgoto nos rios, mas permanecem os baixos índices de tratamento de esgoto na metrópole.

No entanto, ao longo da década de 1990, o propósito principal do Projeto Tietê se transfere para a drenagem. Será o caso do Plano Diretor de Macrodrenagem da Bacia do Alto Tietê, construído pelas instituições ao longo da década de 1990 e lançado em 1998, o qual conta com financiamento dos mesmos agentes que financiaram a despoluição, bancos japoneses e o Banco Mundial, e que reestruturou o modelo de drenagem urbana da Região Metropolitana de São Paulo, basicamente com as ações de aprofundamento da calha do rio Tietê e com a construção da rede de reservatórios de contenção de cheias, popularmente conhecidos por "piscinões". O apelo ambiental configurado no termo "vazão de restrição" propugna a sustentabilidade da drenagem urbana na metrópole. As obras estruturais acima visam ordenar o escoamento fluvial para níveis "sustentáveis" no rio principal, o Tietê, e para isso os reservatórios têm a função do controle de vazão ${ }^{80}$.

A "(in)sustentabilidade" da drenagem urbana passa pela própria incorporação dos ambientes fluviais ao processo urbano. Mais do que isso, se explicam num sistema maior, a Bacia do Alto Tietê, cujas transformações e os efeitos da objetivação física da engenharia e da técnica sobre o sistema fluvial desta Bacia, que em certa medida corresponde à sua própria área metropolitana, alterou profundamente os componentes superficial e fluvial da drenagem potencializando em intensidade e frequência as inundações em todas as sub-bacias. Parece que quanto mais se operam as transformações para a sustentabilidade da drenagem, mais ela se torna insustentável. Contudo, essa característica permite uma continuidade quase interminável de obras as mais variadas para o controle das inundações. A complexidade do problema chegou a níveis que, quanto mais a técnica e a engenharia explicam, mais incompreensível o problema se torna.

\footnotetext{
${ }^{80}$ A respeito dos reservatórios de retenção ver os trabalhos de Delmar MATTES - O espaço das águas. São Paulo: Dissertação de Mestrado. Faculdadade de Arquitetura e Urbanismo. 2001; e SILVA, 2009.
} 
Grosso modo, podemos elencar algumas questões importantes para a compreensão da problemática, ou mesmo para se perder nessa compreensão, o que seria mais admissível. Alterações dos níveis do talvegue em relação aos originais, alterações do processo de sedimentação e transporte de material em função de aprofundamentos de calha, transposições, barragens, elevatórias, enfim todo um comprometimento dos níveis de base da bacia do Alto Tietê, elemento estruturador dos processos de erosão, transporte e sedimentação em toda a região. Ao se alterarem tais níveis, ocorre que processos de transporte e sedimentação tendem, principalmente com a construção das inúmeras barragens do sistema Light, ao assoreamento, ou seja, ao comprometimento do volume de vazão no canal do rio, com tendência recorrente ao extravasamento. Combina-se isso à própria forma urbana, à metrópole como expressão do espaço construído fato que torna parte significativa do solo impermeável (não nos enganemos, pois que solos permeáveis também predispõem o escoamento superficial, o qual, dadas as suas qualidades, podem atingir em tempos variados o nível de saturação e permitir a predominância absoluta do escoamento superficial).

Outro elemento significativo foi a própria apropriação urbana dos rios e das várzeas em São Paulo. Ocorreram na forma de canalização e retificações, de uma predominante ideia de que o escoamento deveria ser rápido, a vazão dos rios acelerada por dois motivos, um ligado à ideia primordial de saneamento, levar as águas contaminadas rapidamente para longe, e de que a vazão acelerada evitaria as inundações, desde que combinada com o aumento do volume de escoamento do canal. Dentro dessa lógica da engenharia, difundem-se então, na Bacia do Alto Tietê, as canalizações como obras necessárias ao controle das inundações. No entanto, aconteceu ao contrário, com vazões cada vez mais rápidas, as inundações também tiveram aumento em frequência e intensidade. O sistema de drenagem "original" é de uma densidade considerável, em torno de dois quilômetros de canais por quilometro quadrado de área ${ }^{81}$, ou seja, o escoamento superficial atinge rapidamente aos rios e estes recebem grandes volumes que possibilitam o extravasamento.

${ }^{81}$ Nas medições que realizei para o Trabalho de Graduação Individual (TGI) na Bacia do Pirajuçara a densidade de drenagem média foi de $2,2 \mathrm{~km} / \mathrm{km}^{2}$. Ver Marco Antonio Teixeira da Silva: As enchentes na Bacia do Pirajuçara. São Paulo: Trabalho de Graduação Individual Universidade de São Paulo, 1999. 
Transportam também esses grandes volumes para áreas de confluência da drenagem, extensas planícies fluviais localizadas principalmente a partir dos trechos médios das sub-bacias do Alto Tietê. Essas áreas se tornaram pontos recorrentes de inundação em São Paulo ${ }^{82}$, justamente porque se relacionam com a própria condição natural dessas vastas planícies, de áreas de espraiamento das águas, com volumes cada vez maiores e mais rápidos de vazão fluvial.

O escoamento fluvial se altera de maneira significativa em situações de pluviosidade, mesmo aquelas não tão intensas, que dirá nos chamados eventos excepcionais ${ }^{83}$, presentes nas normais climatológicas de maneira intermitente, com uma temporalidade difusa, mas presentes nas medições históricas em diversos períodos ${ }^{84}$. Acontece que esse processo na atualidade tem uma dimensão concreta, mas que escapa à racionalidade por sua complexidade definida a partir das inumeráveis alterações urbanas. Tais alterações complexificaram situações antes passíveis de resposta, hoje difíceis de serem apreendidas. Para não complicar muito, quais os atuais níveis de base $^{85}$ dos rios principais e secundários da bacia? Com a impermeabilização dos talvegues, rebaixamentos das calhas, processos de assoreamento, alterações de confluência, barragens, transposições, só para citar alguns, de que maneira se lê o primordial processo erosão, transporte e sedimentação em uma bacia qualquer em São Paulo?

\footnotetext{
${ }^{82}$ No trabalho sobre as inundações na bacia do Pirajuçara, destacam-se o Largo do Campo Limpo e o Largo de Taboão da Serra, pontos de confluência de importantes rios da Bacia do Pirajuçara onde o fenômeno das confluências relacionado ao das inundações tornou-se recorrente. (Ver Marco Antonio Teixeira da SILVA: As enchentes na Bacia do Pirajuçara. São Paulo: Trabalho de Graduação Individual: FFLCH-USP, 1999.).

${ }^{83}$ Conforme Carlos Augusto de Figueiredo MONTEIRO, os eventos extremos são aqueles com frequência de longo período, diferente dos excepcionais, que apresentam desvios em relação à média, mas ocorrem em frequências menos espaçadas.

${ }^{84}$ Em meu Trabalho de Graduação Individual, pesquisei vários anos de dados pluviométricos de postos da Bacia do Pirajuçara, tanto fornecidos pelo Departamento de Águas e Energia do Estado de São Paulo (DAEE) como pela Administração Regional do Campo Limpo (as atuais Subprefeituras). Nas análises desses dados, repetiam-se pluviosidades em torno de $100 \mathrm{~mm}$ em torno de 10 anos. Ver Marco Antonio Teixeira da SILVA: As enchentes na Bacia do Pirajuçara. São Paulo: Trabalho de Graduação Individual: FFLCH-USP, 1999.

85 "[...] deve-se admitir que toda vertente evolui em função de um nível de base (qualquer ponto localizado à jusante se constitui em nível de base para evolução do localizado à montante), como o curso d'água em questão que comandará a intensidade dos processos morfogenéticos. Portanto, a vertente, em seu sentido amplo, necessariamente incorporará a presença de um curso d'água ou nível de base que anula os processos areolares, como ponto de referência para seu próprio desenvolvimento." Ver Valter CASSETI: Ambiente e Apropriação do Relevo. São Paulo, Contexto 1991 (p. 60/61).
} 
Toda essa problemática das inundações, de certo modo, corrobora para o deslocamento das prioridades entre despoluição e drenagem metropolitana justamente pela questão da circulação viária, cuja eficiência se justifica na própria condição da drenagem, visto que o sistema metropolitano está assentado no sistema hidrográfico e a principais artérias viárias são também os rios principais, Pinheiros e Tietê, ou seja, as vias marginais que conectam todo o sistema de avenidas de fundo de vale (ver Apêndice: Mapa I). Essa mudança de prioridades impõe também uma significativa mudança de modelos em termos de drenagem urbana. O predomínio de um modelo anterior ligado ao escoamento fluvial rápido passa, a partir do Plano Diretor de Macrodrenagem, por uma significativa mudança, torna-se um modelo de retenção do escoamento, já mencionado anteriormente. Embora haja uma ruptura de modelos de drenagem há também uma permanência de mentalidade quanto à incorporação do sistema hidrográfico ao sistema viário. Mais do que isso, tal incorporação se aprofunda ao relacionar as obras do novo modelo de drenagem à expansão do sistema de avenidas de fundo de vale.

De todo modo, esse momento de mudanças traz em seu bojo novas ideologias que impulsionam a lógica da produção do espaço ao apregoar como necessários tais modelos. De maneira mais simples, os problemas de tráfego em São Paulo quase nunca se justificam pela produção automobilística, pelo aumento permanente da frota, pela insuficiente rede de transportes públicos, ou mesmo pela condição do automóvel como objeto privado que identifica e é identificado ao indivíduo na modernidade, torna-se objeto não somente de fluir pelo espaço, mas de fruir no espaço. $O$ individuo privado se identifica também no tempo e no espaço da metrópole no interior de seu objeto automóvel ${ }^{86}$. Dessa forma, as políticas de produção do espaço urbano sempre implicam na objetivação exponencial do sistema viário. A contradição é que quanto mais 0 sistema viário se expande, menos o automóvel flui ${ }^{87}$. Tanto que há tempos a expansão viária vem acompanhada da proibição à própria circulação viária. $\mathrm{A}$

\footnotetext{
${ }^{86}$ Não é à toa que Henri Lefebvre chama o automóvel de "objeto rei" (LEFEBVRE, 1972, op. Cit.). Outra visão, mais artística e não menos analítica sobre o indivíduo, o automóvel, tempo, espaço e modernidade é o conto "La Autopista del Sur" de Julio CORTAZAR: Todos los fogos el fuego. Madri: Punto de Lectura, 2009.

${ }^{87}$ De maneira irônica mas não menos analítica, Robert Kurz, em meio a esta contradição irresoluta no mundo moderno, nomeia o automóvel de autoestático. Ver "Com todo o vapor para o caos da crise", in KURZ, 1997, op. Cit.
} 
proibição de motos na via expressa da Marginal Tietê a partir de 02 de agosto de 2010 é um exemplo. Os cada vez mais frequentes acidentes com motos (mais de quatrocentas mortes de motoqueiros na cidade de São Paulo conforme dados da Companhia de Engenharia de Tráfego em 2014) restringem a circulação viária na cidade. Os caminhões a partir de 05 de março de 2012 também passaram a ter horário de circulação restrito para não "atrapalharem" o tráfego nas vias Marginais.

Percebe-se que as Vias Marginais, principalmente a Marginal Tietê, se tornaram objetos centrais da política viária em São Paulo. As problemáticas acima relatadas revelam um discurso de fluidez necessária aos carros, ao mesmo tempo em que encobrem as contradições socioespaciais deste processo $^{88}$. Entram nesse escopo das problemáticas as inundações, mas estas são centrais na análise do jogo político e ideológico que interessa a esta pesquisa, pois revelam a trama que envolve os pressupostos ambientais como estruturadores do processo de financiamento que amarra as diversas áreas da metrópole nos termos da compensação ambiental e predispõem as reservas territoriais como compensação para que haja o incremento do sistema viário, por exemplo, com a construção da terceira pista da Marginal Tietê.

$\mathrm{Na}$ lógica das agências internacionais de financiamento, como o BID, a condição ambiental torna-se fator significativo, sobretudo pelas contrapartidas aos novos termos do financiamento da produção do espaço, as chamadas compensações ambientais, áreas destinadas a recompor as perdas ambientais proporcionadas por grandes obras. Sem tais compensações, as operações de financiamento são restritas.

E é essa forma elementar, combinando financiamentos públicos e privados, nacionais e internacionais, que assumem esses e outros projetos, cujo significado se apresenta nas diferentes condições de apropriação urbana dos rios e das várzeas, como é o caso dos diversos Parques Lineares que serão construídos ao longo de rios e várzeas da metrópole paulistana ${ }^{89}$. Essa

${ }^{88}$ A pesquisa de Tatiana SCHOR faz um debate sobre essa questão em São Paulo, a incessante produção do automóvel e de suas necessárias estruturas como condição imanente do colapso da circulação viária. Ver: O Automóvel e a Cidade de São Paulo: a territorialização do processo de modernização (e de seu colapso). São Paulo Dissertação de Mestrado: FFLCH USP, 1999.

${ }^{89}$ Na Lei no 13.430 , de 13 de setembro de 2002 (Plano Diretor Estratégico do Município de São Paulo), está disposto o Programa que formula a política de criação de Parques Lineares 
se torna a tendência primordial para a continuidade da apropriação urbana de rios e várzeas, a expansão do sistema viário em dados espaços em concomitância aos termos da sustentabilidade a partir da "requalificação" de outras áreas em que esses ambientes fluviais possam "retornar" para sua função original de amortecimento de cheias, de leito maior de rios, de espaço de mata ciliar. É a lógica da compensação ambiental nas leituras sobre a produção do espaço.

O que se percebe em São Paulo, no caso particular do Parque Várzea do Tietê, é que se amarram políticas de compensação ambiental à continuidade e ampliação destes mesmos ambientes como sistema viário metropolitano. Vários núcleos do Parque Várzea do Tietê são compensações dos projetos viários: a terceira pista da Marginal Tietê, a Avenida Jacú-Pêssego e o Rodoanel trecho Leste (ver Apêndice: Mapa I). Dessa forma, os espaços empobrecidos da cidade passam a compor uma lógica política definida nos termos dos discursos e políticas ambientais, tornam-se áreas institucionalizadas pelos atributos de natureza que possuem, mas que se referem aos novos momentos das políticas de financiamento internacional e servem a estas como meio de realização das formas financeiras da relação capital-espaço. Por tanto, aparece uma política ambiental que socorre tanto o sistema viário metropolitano como a população que vive sob o risco ambiental, mas se apresenta uma lógica que relaciona o capital financeiro às possibilidades de sua territorialização como momento de sua realização.

Por fim, a relação entre os elementos dispostos acima é o que dá o caráter estratégico a essa região denominada de Pantanal da Zona Leste para a formulação das políticas do espaço, dentre elas a implantação dos diversos mecanismos jurídicos de proteção ambiental e de restrição ao risco. Nessa e por essa relação é que se constituem as estratégias de produção do espaço.

juntamente com a remoção de populações. Conforme seu artigo 106: "Fica instituído o Programa de Recuperação Ambiental de Cursos D'Água e Fundos de Vale compreendendo um conjunto de ações, sob a coordenação do Executivo, com a participação de proprietários, moradores, usuários e investidores em geral, visando promover transformações urbanísticas estruturais e a progressiva valorização e melhoria da qualidade ambiental da Cidade, com a implantação de parques lineares contínuos e caminhos verdes a serem incorporados ao Sistema de Áreas Verdes do Município". 
Parte 3

Pantanal 


\section{Capítulo IX}

\section{As Várzeas do Pantanal na Lógica da Financeirização}

Os ambientes fluviais foram se configurando como espaços de moradia ao longo da metropolização de São Paulo. Esse processo se deu, como em todo o espaço da metrópole, de maneira desigual. Como já vimos acima, estratégias de valorização empreenderam negócios com grupos abastados os quais se fixaram nos ambientes fluviais, ao mesmo tempo em que boa parte desses ambientes foi ocupada por populações empobrecidas. As terras públicas, as sobras do mercado imobiliário, as ocupações, tudo isso configurou ao longo de boa parte da rede de drenagem da metrópole um vasto contingente empobrecido e algumas áreas muito valorizadas. Todos de alguma maneira implicados nas particularidades das várzeas, mas de maneira mais incisiva a população empobrecida e que habita áreas sem aporte de estruturas de combate às inundações. O Pantanal da Zona Leste é um exemplo deste contexto de ocupação das várzeas por populações empobrecidas. Mas a história que se desenvolve aqui é um pouco mais complexa do que isso. Por "N" vezes já se falou da relação capital-espaço, de que houve uma acumulação de espaço ao longo da metropolização e de que essa acumulação serve à reprodução financeira. Mas há um campo de enfrentamento para todo esse processo, que se dá no cotidiano dos moradores, onde a expropriação é estratégica e procura se resolver por uma violência velada que possa ser lida socialmente como necessária, que torna-se representação social geral e particular, que possa operar sem deixar feridas aparentes, sem revelar a luta que se desenvolve no espaço urbano e ser aceita socialmente como necessária e primordial para o bem coletivo. É dessa incomensurável sutileza que tratamos adiante.

Como espaços de moradia, os ambientes fluviais eram pouco prováveis ou até inexistentes em finais do século XIX e primeiras décadas do XX, conforme nos relata Aziz Ab'Saber: 'Enquanto a cidade permanecia nas colinas e por elas se expandia nas mais diversas direções e planos altimétricos, as várzeas paulistanas mantiveram-se com uma historia urbana muito modesta e marginal" (AB'SABER, 1957 p. 155). No entanto, passam a compor o frenético 
mercado de terras, sobretudo a partir dos anos 50, configurando espaços de moradia de diferentes grupos sociais. Encontram-se as mais variadas formas de ocupação das várzeas na metrópole paulistana. Primeiramente, um sistema de avenidas de fundo de vale que articula as diversas regiões da metrópole, que desde fins do século XIX se mantém como forma objetiva de apropriação dos rios e várzeas, mesmo que, em alguns casos, não se articule diretamente ao sistema viário como um todo. Um sistema técnico composto por barragens nas cabeceiras dos rios Tietê e Pinheiros, complementado por outro sistema elevatório também composto por barragens ao longo destes rios, além das barragens das usinas Edgar de Souza, Rasgão e Henry Borden, a jusante do sistema (para esta última, o termo jusante é considerado a partir da reversão do rio Pinheiros).

Ao longo do sistema viário metropolitano objetivaram-se edifícios ligados principalmente ao setor terciário, que se diferenciam de acordo com a valorização da área: de um lado, pequenas oficinas automotivas, depósitos de material reciclável, armazéns paupérrimos, como é o caso da Avenida do Estado ao longo do rio Tamanduateí na região central de São Paulo; de outro, prédios de luxo, escritórios do setor de ponta da economia, estúdios de grandes emissoras de TV nas margens do rio Pinheiros e seus tributários como Águas Espraiadas, margeados pelas vias do mesmo nome.

As moradias também variam conforme a área: os bairros Jardins, setor sudoeste da cidade de São Paulo, cuja urbanização "caprichosa" chamou a atenção de diversos autores como Caio Prado Junior e Aziz Ab'Saber ${ }^{90}$, e que foi a moradia da elite paulistana ao longo do século XX. Mas são as numerosas favelas, os ditos loteamentos irregulares, as ocupações, as formas mais precárias de moradia, as que predominam nessa situação.

Ao elencarmos as diversas formas de uso dos rios e várzeas da metrópole de São Paulo, queremos chamar a atenção para condição de uso desses compartimentos por toda a metrópole, pois, como foi dito anteriormente, tais compartimentos se constituíram como forças produtivas da sociedade ao longo da metropolização de São Paulo, e assim se constituem, como

\footnotetext{
90 Tal região é citada como caprichosa obra urbanística nas obras desses autores, respectivamente em "A Cidade de São Paulo" (1943, op. Cit.) e "Geomorfologia do Sítio Urbano de São Paulo" (1957, op. Cit.).
} 
objetivação de diversos usos. No entanto, as formas jurídicas de restrição implementadas ao longo das últimas décadas incidem somente em determinadas áreas e não para o seu conjunto, que é apropriado por diferentes objetivações urbanas. O Parque Várzea do Tietê, por exemplo, cujo projeto prevê restrições de ocupação desde a área de nascentes, no município de Salesópolis, se interrompe a jusante da Barragem da Penha, trecho percorrido pela Marginal Tietê e densamente urbanizado, para retornar como área de restrição mais a jusante, a partir do município de Carapicuíba (ver Apêndice: Mapa 1).

Essa lógica pressupõe a produção desigual do espaço que define a partir dos termos jurídicos as intervenções em espaços específicos. Situa-se aqui uma estratégia que dá significado à compreensão da produção desigual do espaço nos atuais termos dos financiamentos embasados nas compensações ambientais, a de que a parte sujeita a legislação restritiva de uso torna-se, no interior da própria legislação, a objetivação da outra parte, ou seja, as obras que ampliam a inserção das várzeas no processo de circulação viária, como a terceira pista da Marginal Tietê, assim como outras obras de circulação viária não necessariamente nas várzeas, como o Rodoanel, requerem espaços legislados, normatizados em suas formas de uso e que essas mesmas legislações predisponham usos restritivos para assegurar tais áreas como compensações ambientais, por exemplo, que vastas áreas do Parque Várzea do Tietê se destinem ao plantio de árvores como compensação pelos desmatamentos das referidas obras viárias.

A institucionalização dos rios e várzeas na metrópole de São Paulo remonta períodos da década de 1960, com a promulgação do Código Florestal em 1965 (Lei 4771/65). Embora essa legislação previsse restrições à ocupação das várzeas de acordo com a variação da largura do rio, em São Paulo assim como em outras tantas cidades brasileiras, as restrições nunca ocorreram de fato. Veja-se que ao ser publicada, a lei já não correspondia a realidade dado o andamento da construção das vias marginais Pinheiros e Tietê, só para citar as principais.

Na década de 1970 houve nova tentativa de institucionalização da várzea do Tietê (Lei 7868/76) a partir da lei que instituiu a criação de Parques nas várzeas dos rios, e que será o embrião do Parque Ecológico do Tietê, em 
cujo texto declarava o ambiente fluvial das várzeas do Tietê a montante e jusante das vias marginais como área de utilidade pública. Tal situação conflitava com a própria ocupação da várzea e sua questão fundiária, uma vez que várias indústrias mantinham suas atividades nessas terras: Tamboré Alimentação S/A; Fama S/A; Miguel Badra; Klabin S/A; Indústrias Reunidas Matarazzo; Atlas S/A; Nitro Química; só para citar algumas. Diante dos possíveis conflitos fundiários para requerer as terras da várzea do Tietê como públicas, o Governo do Estado propõe a revogação parcial da área de utilidade pública.

O traçado proposto do Parque Várzea do Tietê ainda acompanha essa lógica. A forma como se apresenta o projeto de criação do Parque se resguarda também na representação cartográfica que é usada para esconder ao invés de revelar o que se situa sob o plano cartográfico. Como um lençol que se sobrepõe ao território e suprime sua objetivação como forma, seu cotidiano como conteúdo. Essa representação cartográfica usada nos relatórios enviados pelo Governo do Estado de São Paulo ao BID tem justamente essa função. Vemos num dos mapas a área em "Verde" como representação da área do Parque, uma massa areolar em torno do rio Tietê, que em certa medida corresponde às áreas permeáveis:

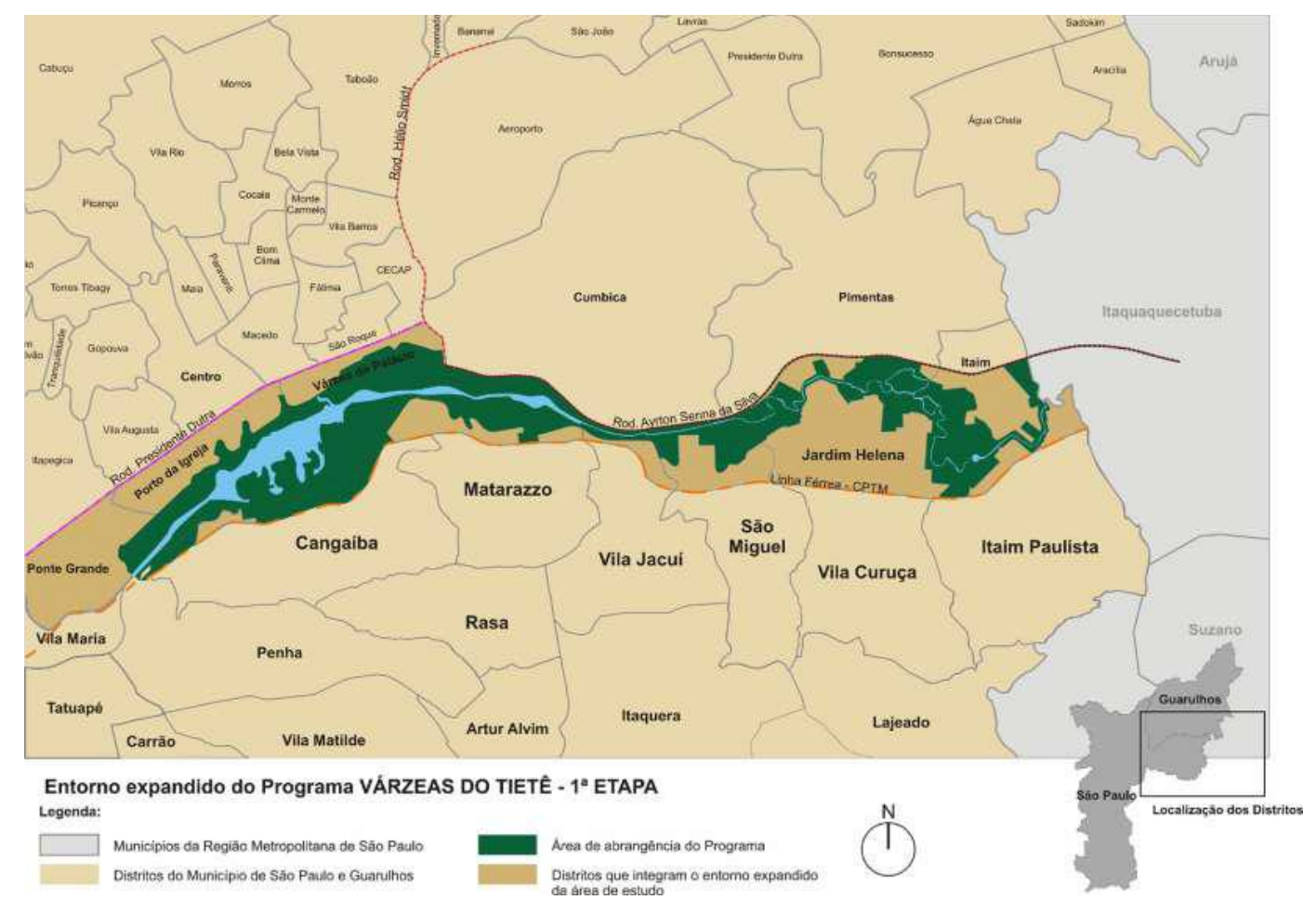

Fonte: São Paulo, 2010bA p. 22. 
No entanto alguns "recortes" chamam a atenção. Alguns levantamentos revelaram que o perímetro do Parque não avança sobre certas propriedades de instituições que também estão na várzea do Tietê e não estão em conflito com - Parque, fato muito comentado pelos moradores. Algumas situações já referidas como a preservação da certas propriedades fundiárias parecem explicar tendências ao traçado perimetral, como expõe a imagem abaixo, compilada a partir da anterior:

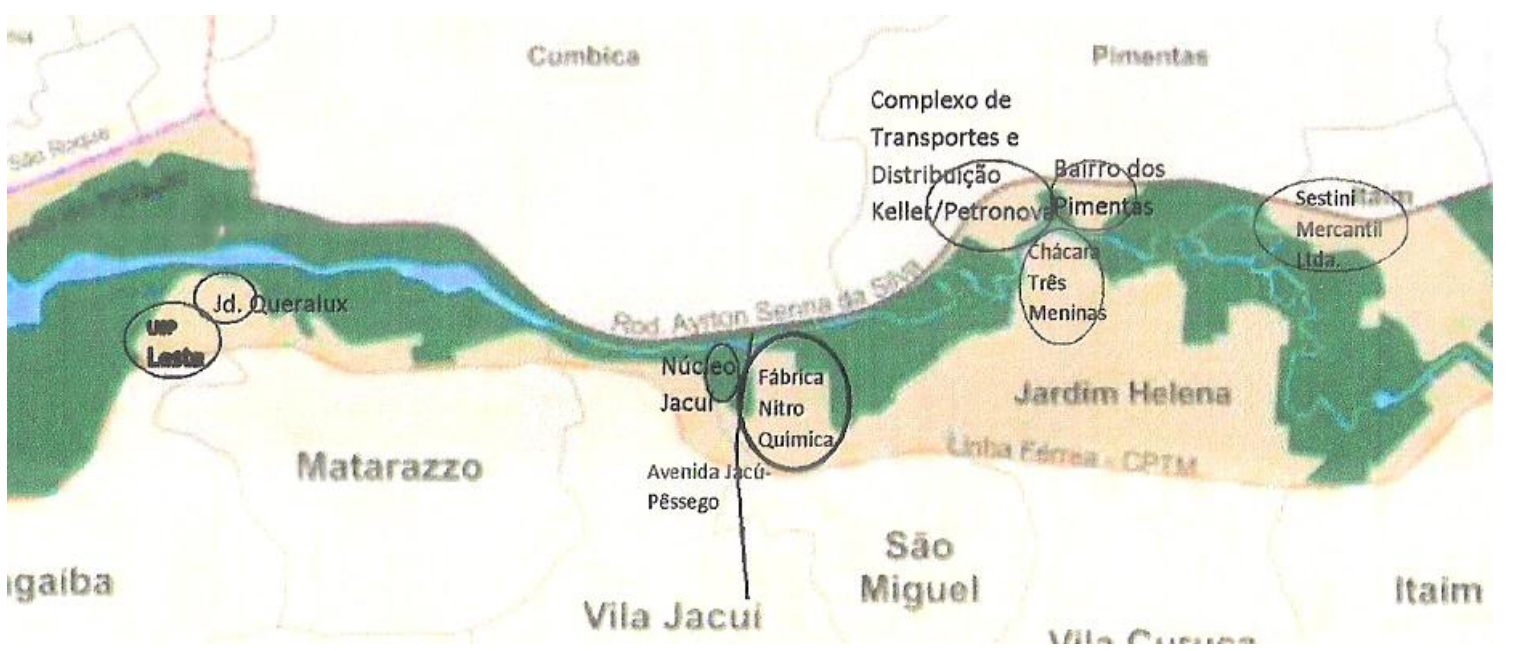

Edição a partir da fonte: São Paulo, 2010bA, p. 22.

O mesmo mapa com algumas referências fundiárias revela que certos "recortes" no perímetro referem-se a áreas privadas, como são os casos da Fábrica Nitroquímica, do complexo de transportes Petronave/Keller, da Sestini Mercantil; ou os usos públicos, como é caso do Campus da USP Leste, do Conjunto Habitacional São Miguel, entre outros. Desde a década de 1980, diversas foram as legislações que sobre esta área incidiram. Estabeleceram perímetros de restrição mais ou menos correspondentes à área da planície fluvial. Dada a diversidade de usos, tais legislações se constituíram a partir de zoneamentos, os quais procuraram preservar a edificação de usos institucionais e outros particulares, um conflito fundiário que se estabelece desde a criação da legislação restritiva sobre a várzea do Tietê e se projeta nas formulações atuais da restrição ambiental.

Ao contrário destes, os usos residenciais não-institucionalizados situados nesses ambientes fluviais passaram a ser, em sua maioria, considerados indevidos no escopo jurídico dessas legislações. Melhor, 
duplamente indevidos. Em primeiro lugar a partir dos pressupostos jurídicos em que estão embasados os termos da propriedade privada do solo urbano, uma vez que trata-se em principalmente de lotes sem registro legal; depois, e também com base no pressuposto anterior, como lotes localizados em áreas definidas juridicamente dentro de perímetros de proteção ambiental no interior dos quais a moradia é proibida, conforme prevê o Decreto № $42.837^{91}$, de 3 de fevereiro de 1998: "Artigo 14 - VIII - remoção das edificações instaladas nas faixas de preservação dos corpos d'água, estabelecidas pelo Código Florestal $^{92}$, e em áreas de risco".

Ao mesmo tempo, ou seja, com a vigência do Código Florestal desde a década de 1960, a situação à jusante, no trecho de várzeas que corresponde à Via Marginal do Rio Tietê, assim como acontece no rio Pinheiros, permanece toda a sorte de negociações com as terras "varzeanas" (novamente, o Apêndice - Mapas 1 e 2, é ilustrativo), inclusive com elevados preços por metro quadrado, como é o caso do sudoeste da cidade, na região que compreende as avenidas Nações Unidas (Marginal Pinheiros) - Luís Carlos Berrini - Águas Espraiadas, um monumental eixo correspondente ao setor imobiliário ligado ao terciário moderno. Aliás, por todo este eixo de avenidas de fundo de vale, que corresponde ao eixo fluvial principal da bacia de São Paulo, as vias marginais Tietê e Pinheiros, se objetiva um corredor de comércio e serviços que corresponde a grandes redes de grupos variados, desde supermercados, magazines, lojas de material de construção, e toda a sorte de serviços.

Ao sairmos da região que corresponde ao eixo das marginais Pinheiros e Tietê, novamente passa a valer a legislação ambiental, como o respectivo Decreto propõe: "que declara área de proteção ambiental regiões urbanas e

${ }^{91}$ Este decreto regulamenta a Lei $\mathrm{n}^{\circ} 5.598$, de 6 de fevereiro de 1987, "que declara área de proteção ambiental regiões urbanas e rurais ao longo do curso do Rio Tietê, nos Municípios de Salesópolis, Biritiba Mirim, Mogi das Cruzes, Suzano, Poá, Itaquaquecetuba, Guarulhos, São Paulo, Osasco, Barueri, Carapicuíba e Santana do Parnaíba, e dá providências correlatas".

92 Lei Federal o 4.771, de 15 de setembro de 1965, conhecida como Código Florestal, que institui regulações na ocupação das margens dos rios nacionais de acordo com sua largura. Não foi o caso, por exemplo, das planícies dos rios Tietê e Pinheiros ao longo da cidade de São Paulo, as quais, mesmo após a regulamentação, continuaram a ser integradas ao processo de modernização como forças produtivas sociais. 
rurais ao longo do curso do Rio Tietê, nos Municípios [...] São Paulo ${ }^{93}$, Osasco, Barueri, Carapicuíba e Santana do Parnaíba, [...]”.

A área correspondente ao trecho das vias marginais se "exclui" do perímetro restritivo da legislação ambiental. No entanto, como foi para o caso da ampliação da Marginal Tietê pela construção de sua terceira pista, o trecho de legislação restritiva serviu como forma de compensação ambiental ao impacto causado pela obra de ampliação desta via. Podemos dizer então exclusão-inclusão, pois que este trecho se relaciona àquele correspondente ao perímetro das legislações restritivas de maneira que as intervenções objetivadas não somente na área das vias marginais, mas em várias outras dentro da metrópole de São Paulo acabam por requisitar áreas de compensação ambiental, estas que se constituem justamente nos territórios empobrecidos da metrópole, situados em muitos casos ao longo dos rios, desprovidos de aparato legal da propriedade privada e que, nos termos da legislação ambiental se constituem como áreas de restrição à moradia.

Ocorre que uma massa significativa de terras passa a se constituir como reserva para compensações por grandes obras estruturais já executadas, em execução, ou mesmo projetadas. Áreas legisladas no escopo ambiental tornam-se estratégicas neste processo. Por esse motivo, suas legislações específicas atuam no sentido de manter a reserva territorial por décadas entre a sanção da Lei e a execução de qualquer projeto. Veja-se que a ocupação do Pantanal remete à década de 1970 e que de lá para cá se sobrepõem diversas legislações que garantem o território institucional resguardado por cinco décadas, embora sistematicamente ocupado pela constituição da moradia e outras atividades.

E são nessas áreas institucionalizadas por seus atributos ambientais que ocorrem obras de grandes proporções na atualidade. Como podemos conceber que a obra do Rodoanel Metropolitano acontece em boa medida em áreas de restrição por legislação ambiental, como é o caso da Área de Proteção de Mananciais? A derrubada de florestas, as mudanças hidrológicas, da geomorfologia, todos esses ditos impactos ambientais aconteceram pela construção do Rodoanel justamente em áreas protegidas pela legislação. E

\footnotetext{
${ }^{93}$ Leia-se São Paulo a jusante e a montante da Marginal Tietê.
} 
como poderia ser diferente? Não poderia! Este é o pressuposto posto pela própria lógica da relação capital-espaço contemporânea. E é esta construção que se define no interior das estratégias do espaço como fiduciário, ou seja, que essas legislações restritivas garantem grandes reservas territoriais tanto para a construção como para a compensação ambiental em voga na atualidade. O Rodoanel, em diversos trechos, foi construído em áreas legisladas e sob restrição, espaços mantidos por essas mesmas legislações ao longo de muitos anos, e que agora servem ao propósito da realização do anel viário metropolitano. Mais do que isso, tais áreas são a contrapartida dos financiamentos internacionais, das formas contemporâneas de realização do processo financeiro global. São estes os pressupostos da acumulação de espaço.

Para o caso do Pantanal da Zona Leste, o processo de legislação restritiva tornou esta área uma reserva territorial, um espaço acumulado destinado às obras viárias ocorridas e a ocorrer em outras áreas da metrópole, como foi o caso da compensação ambiental para a ampliação da Marginal Tietê com a construção de sua terceira pista.

Os projetos (do Parque Várzea do Tietê) para São Paulo estão mais adiantados em função das obras da via Parque que nesse município será construída pelo DERSA com verba de compensação ambiental referente à ampliação da avenida marginal ao rio Tietê (SÃO PAULO, 2010b p. 40).

Da mesma forma aconteceu com a ampliação da Avenida JacúPêssego, também na Zona Leste da Capital, ao longo do rio com o mesmo nome, construída na vigência do projeto PROCAV, anteriormente mencionado. Como o trecho leste do Rodoanel ainda não estava em operação no período desta pesquisa (foi recentemente inaugurado), a referida avenida servia de ligação do trecho sul do Rodoanel às rodovias da região leste de São Paulo que interligam a metrópole às outras regiões do estado paulista assim como a outros estados do país. São os casos da Rodovia Presidente Dutra (Vale do Paraíba e Rio de Janeiro), Fernão Dias (Sul de Minas e Belo Horizonte) e Rodovia Ayrton Senna (Vale do Paraíba e litoral paulista). As compensações ambientais da construção, reforma e ampliação da Avenida Jacú-Pêssego situam-se também no Pantanal da Zona Leste, na construção de um dos núcleos do Parque, o Núcleo Jacú-Pêssego (ver Apêndice: Mapas 1 e 2). 
A área onde se localiza o novo parque foi disponibilizada a partir da remoção de ocupações irregulares durante as obras de implantação da interligação da rodovia Ayrton Senna com a Avenida Jacu Pêssego e representam a compensação ambiental pela implantação das obras de extensão da JacuPêssego até o trecho Sul do Rodoanel. ${ }^{94}$

O Núcleo "Vila Jacuí", foi executado pela empresa de Desenvolvimento Rodoviário S/A - DERSA, em decorrência de compensação ambiental das obras do complexo viário JacuPêssego, não onerando o presente Programa (SÃO PAULO, 2010b p.26).

As imagens abaixo localizam o Núcleo Jacuí (em destaque), construído como compensação ambiental na primeira fase de remoção das famílias que habitavam a várzea do Tietê. As obras se iniciaram no ano de 2010 (imagem da esquerda) e sua inauguração em março de 2011(imagem da direita). Está situado ao lado da Fábrica Nitroquímica (direito nas imagens) e, entre os dois, a Avenida Jacú-Pêssego, uma das vias que teve sua compensação ambiental ligada à construção deste núcleo. Este foi o primeiro núcleo consolidado do Parque Várzea do Tietê e serviu de compensação ambiental para obras viárias financiadas pelo BID.

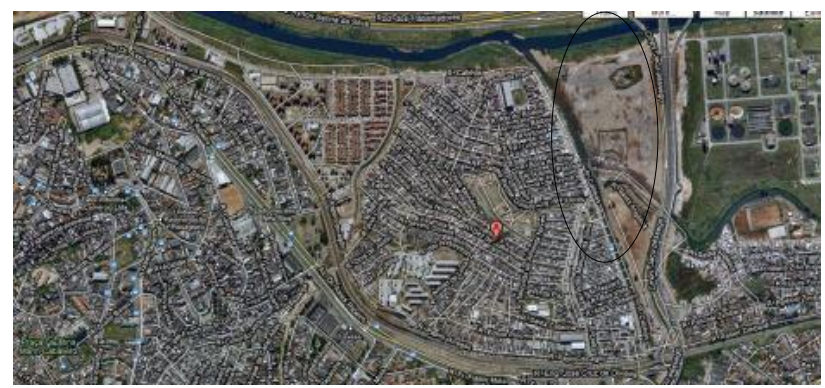

Disponível em (acesso 12/2014)

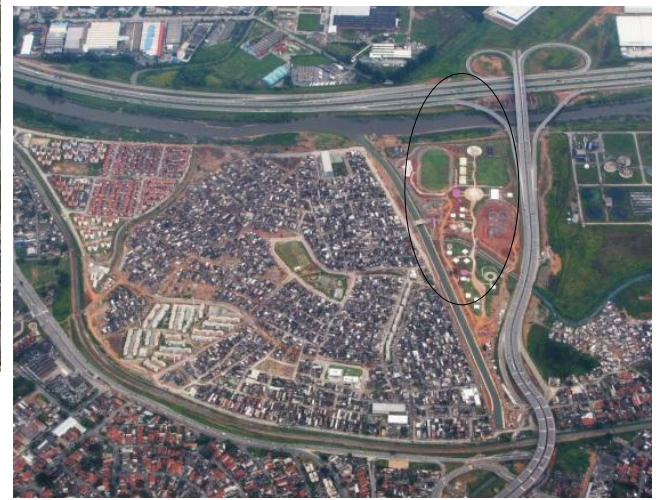

http://www.alltravels.com/brazil/sao-

paulo/guarulhos/photos/current-photo-85407115;

${ }^{94}$ http://www.ecotiete.org.br/noticias/midia 20100327gov.htm. Acesso em abril de 2011 
Dessa forma, torna-se essa área do Pantanal da Zona Leste uma grande massa de terra disponível, um espaço acumulado estrategicamente disposto como forma de compensação ambiental para a objetivação de inúmeras obras no espaço metropolitano. Por outro lado, realiza os preceitos do espaço fiduciário ao disponibilizar um vasto território para financiamentos de variados projetos que se constituem como realização do capital financeiro, neste caso, ao territorializar este capital na construção do Parque Várzea do Tietê por capitais financiados pelo BID os quais se tornam dívida pública na relação capital-espaço.

O Pantanal da Zona Leste de São Paulo passa a objetivar as tramas da economia política. Neste espaço se realiza uma operação definida nos termos da mundialização pressuposta dentro de um contexto político como realização da economia financeira. Um ponto de convergência política e econômica de um momento histórico caracterizado por processos constitutivos que permitem ao capital financeiro "pairar" sobre a superfície do planeta na condição de se territorializar em determinados lugares que the oferecem condições de reprodução. Tomemos emprestada à meteorologia uma analogia que pode nos ajudar a compreender o que significa esta área para nossas proposições. As imagens de satélite do tipo NOAA nos mostram pontos da superfície terrestre para os quais, por conta de diferenças de pressão, convergem grandes massas atmosféricas. São os vórtices. Nossa analogia aqui é de uma situação particular, a situação geográfica definida a partir de condições objetivas que propiciam a convergência das forças políticas e econômicas que governam o processo de reprodução capitalista para um dado lugar, este que se torna espaço potencial da realização dessas condições de reprodução.

A economia financeirizada, esta que paira sobre a superfície do planeta, ou melhor, flutua em ondas eletromagnéticas sustentadas por uma base técnico-científica, como diria Milton Santos, cuja representação são cifras de trilhões de dinheiros, formatados em fundos de pensão, títulos de dívida, comércio cambial, enfim, que se reproduzem de variadas formas, as quais, por impossibilidade de se realizarem objetivamente, o fazem como ficção, e esta acaba por definir a própria realidade. Uma trama complexa e de difícil compreensão, que resulta numa economia política não somente pelo entrelaçamento do político e do econômico de per si, e sim de maneira a se 
estruturar enquanto relações sociais contraditórias obscurecidas pelas representações da economia formal alinhavadas aos ditames das médias sociais.

Ao desvelar as condições da produção do espaço como realização de um processo da economia política que envolve a financeirização dos lugares na forma de financiamentos de projetos e obras os mais diversos, definimos a necessidade da compreensão deste processo à luz dessas relações sociais. Os investimentos realizam formas, produzem estruturas que dinamizam diversos processos, mas o fazem conforme os novos significados que assumem as ideologias e práticas contemporâneas. $\mathrm{O}$ ambientalismo e suas ideias correlatas, tais como a sustentabilidade, configuram-se como indispensáveis na compreensão da produção do espaço na contemporaneidade, uma vez que condicionam os financiamentos a partir de bases consideradas sustentáveis, e por essa lógica é que se definem ou não os projetos a serem contemplados.

(...) as análises sobre o urbano estão sendo invadidas por um "naturalismo" exacerbado, sob a ótica da constituição de uma ideologia do "meio ambiente urbano" pela qual a vida humana em sua complexidade é simplificada pela imposição da ideia de preservação da qualidade de vida como preservação do meio ambiente. Nessa vertente, a naturalização da sociedade reduz o fato social a um fato ambiental (CARLOS, 2001 p.119).

Diante dessa nova condição para os financiamentos internacionais, sobretudo aqueles de instituições tais como o BID, novas estratégias se delineiam na e para a produção do espaço. A sustentabilidade torna-se proeminente para os novos investimentos. O que aparece é a forma jurídica do contrato que estabelece os termos e as convenções que dinamizam novos formatos. Se apresenta na verdade uma forma obscura que se estabelece como poder e dominação. Seus emaranhados não revelam esta condição e se apresentam como igualdade jurídica esclarecedora e democrática, representadas pelas audiências públicas, pelos conselhos paritários, pela participação da sociedade conforme trechos de relatórios do Governo do Estado e também dos órgãos financiadores como o BID esclarecem: 
O processo de intervenção, sempre que possível, não deve interferir nas estruturas de poder existentes nas comunidades, mas sim incorporar suas lideranças nos mecanismos de participação que serão organizados (SÃO PAULO, 2010b p.28).

[...] com o envolvimento efetivo da comunidade para que se transformem em usuários e defensores da infraestrutura e das áreas de proteção a serem implantadas no contexto do Programa (ibidem).

As tramas políticas de tais conflitos expressam uma lógica que transcende a área de estudo, pois situa-se nas formas políticas de realização da economia financeira mundializada. No entanto, tal condição nesta área de estudo se revela particular, pois que nela se situam formas de intervenção propiciadas pelas condições do ambiente fluvial e pela manipulação dos objetos técnicos componentes da Bacia do Alto Tietê. Aliam-se a estes elementos, outras condições postas pela relação entre 0 político e 0 econômico, como a "irregularidade" jurídica da permanência dos moradores nesta área. A articulação desses elementos todos num processo que diz respeito à implantação de uma legislação restritiva revela as tramas políticas da produção do espaço, não como produção de coisas no espaço, mas do espaço em si (LEFEBVRE, 2008 p. 111-2). Justamente por não se tratar simplesmente de coisas no espaço, revela-se pelo estabelecimento de relações políticas e econômicas no interior das relações sociais, ao definir, por vias que vão desde o desejo até a violência, as formas de aceitação das novas condições de produção do espaço no amplo escopo social, a se incluir aqui a própria população removida. Tais elementos compõem a situação geográfica não somente como elementos físicos que se integram ao processo social, mas para além da forma, elementos políticos e econômicos que se relacionam na reprodução contemporânea centrada na financeirização, vórtice para onde convergem os elementos da economia política contemporânea, e o fazem pelas particularidades políticas, sociais, econômicas, naturais da área do Pantanal da Zona Leste.

O Plano Diretor de Macrodrenagem da Bacia do Alto Tietê (1999), por exemplo, que determinou a reestruturação do modelo de drenagem urbano, foi financiado por bancos japoneses e pelo BID a partir de argumentos de sustentabilidade do novo modelo de drenagem urbano, baseado na vazão de restrição, ou seja, cotas de vazão nas sub-bacias do Alto Tietê como 
manutenção da vazão máxima a partir da execução do projeto de aprofundamento da calha do Tietê. Para consolidar a proposta de sustentabilidade, foram concebidos os reservatórios de contenção de escoamento em várias sub-bacias, como é o caso do Pirajuçara, do Aricanduva, das Águas Espraiadas, os quais retém a vazão para que a do Tietê se mantenha nos níveis acordados no Plano. Tais intervenções já são postas como insuficientes conforme relatado no INFORME DE GESTÃO AMBIENTAL E SOCIAL DO PROGRAMA (IGAS - 2010), enviado ao BID como relatório preliminar da execução do PROGRAMA DE RECUPERAÇÃO DAS VÁRZEAS DA BACIA DO ALTO TIETÊ (BR L 1216):

Nestas últimas obras, o Governo do Estado aplicou cerca de um bilhão de dólares americanos, chegando ao limite das obras que poderiam ser feitas no rio para aumentar sua capacidade de vazão, ou seja, não será possível qualquer outra ação estrutural na calha com relação ao controle das enchentes, que seja economicamente viável. [...] Em complemento às obras estruturais realizadas nos cursos d'água principais foram implantados reservatórios de contenção localizados nas subbacias mais densamente ocupadas e com alto grau de impermeabilização (piscinões). Atualmente existem 41 reservatórios de contenção em operação sendo 24 construídos pelo GESP e 17 pelas municipalidades de São Paulo e da RMSP (idem, p. 06).

Nestes termos, o Informe relata como insuficientes as intervenções realizadas até agora, assim como a impossibilidade de que estas continuem no perímetro proposto ao aprofundamento da calha do rio Tietê e sugere como medida necessária a expansão das intervenções para as áreas à montante deste perímetro:

[...] Além das obras já realizadas, outro componente importante para o controle de enchentes na Região Metropolitana são as várzeas localizadas a montante da Barragem da Penha. Com a função natural de amortecer as ondas de cheias, as várzeas devem garantir a descarga de vazão para o trecho de jusante da Barragem da Penha compatível com a capacidade limite do rio (Ibidem).

Tal capacidade é informada no relatório como:

Controlar as vazões no trecho de jusante do Rio Tietê, garantindo a observância da vazão limite estabelecida no projeto de ampliação da calha do Rio Tietê de $498 \mathrm{~m}^{3} / \mathrm{s}$ na seção da referida barragem, mediante ações para recuperação e preservação da várzea no trecho de montante (Idem p. 18). 
O Informe aponta para a necessidade de intervenções na área que compreende a várzea do Tietê à montante da Barragem da Penha, o Pantanal da Zona Leste. O Programa de Recuperação das Várzeas da Bacia do Alto Tietê, que inclui a execução do Parque Várzea do Tietê, financiado em sua maior parte pelo BID a partir do projeto BRL1216, propõe a construção de um Parque Linear ao longo do Tietê, desde a Barragem da Penha até as nascentes em Salesópolis, com 75 quilômetros de extensão, o qual foi dividido em fases, cuja primeira prevê intervenções nos 25 quilômetros iniciais, e é essa que corresponde à área do Pantanal na cidade de São Paulo.

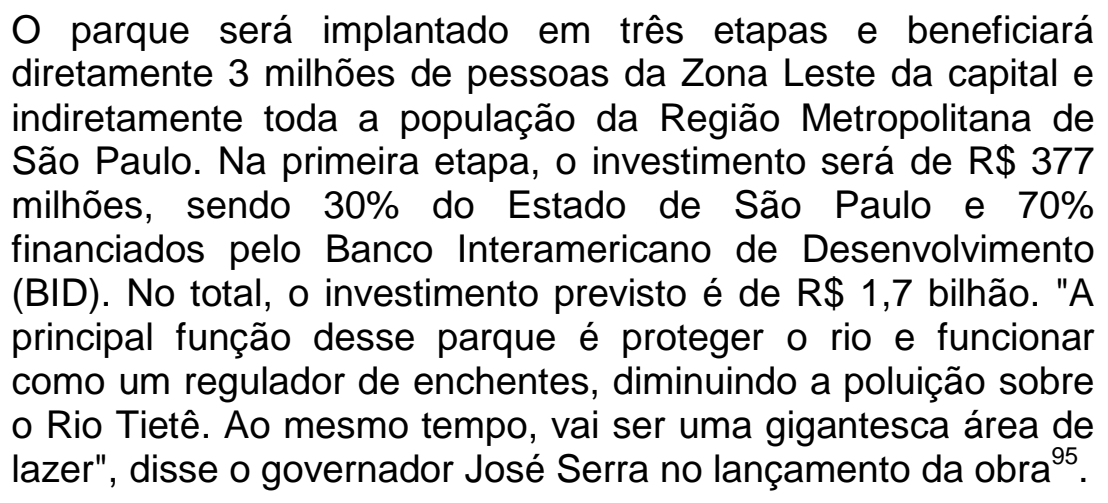

Este projeto (BRL1216) tem como foco principal de financiamento a construção do Parque e financia também serviços ligados à esse objetivo, como os levantamentos sócio-esconômicos de populações a serem removidas, serviços de educação ambiental, serviços de consultoria em empreendedorismo, consultoria em obras, entre outros. Embora para a criação do Parque seja necessário a remoção de oito mil famílias, no que diz respeito ao reassentamento, a parcela do financiamento pelo projeto destinada à construção das moradias corresponde à menor parte. No entanto, o protocolo de reassentamento desta instituição (WASHINGTON, D.C., 1999) orienta toda a produção da documentação por parte do Governo do Estado de São Paulo.

Portanto, o foco principal do BID é a construção do Parque, para o qual o empréstimo é da ordem de 115 milhões de dólares. Por outro lado este interesse na construção do Parque se coaduna a outros tantos projetos que o BID financia ligados justamente à estruturação viária da metrópole paulistana e que passam pela problemática da drenagem, principalmente no que diz respeito ao rio Tietê e suas vias marginais, como foi o financiamento do Plano

95 Conforme o Portal SP Notícias, do Governo do Estado de São Paulo: WWW.saopaulo.sp.gov.br/spnoticias/index.php, acesso em 04/2012. 
Diretor de Macrodrenagem da Bacia do Alto Tietê, ou o atual projeto Rodoanel Mario Covas trecho norte (Projeto BR-L1296:1bilhão e 148,6 milhões de dólares). Conforme o "Relatório de Monitoreio de Progresso - Banco Interamericano de Desenvolvimento - BR-L1216 - Programa Várzeas do Rio Tietê 31 - Out - 2013" (Anexo IV), a construção do Parque implica dois propósitos principais: aumento do tempo de retenção das águas à montante da Barragem da Penha, de 12 horas em 2011 para 14 horas em 2015; e o aumento da capacidade de retenção no mesmo trecho de $800.000 \mathrm{~m}^{3} \mathrm{em} 2012$ para 2.400.000 $\mathrm{m}^{3} \mathrm{em}$ 2015. A lógica do Parque funcionando como reservatório de retenção das águas a partir do fechamento da Barragem da Penha é, sem dúvida, o fundamento da construção do Parque. Essa lógica só pode ser compreendida pela sua relação com o restante da metrópole, pois que este fragmento, conforme já mencionamos, se relaciona a uma totalidade que compreende o sistema viário metropolitano, sobretudo aquele das avenidas de fundo de vale, da expansão do sistema viário com a construção da terceira pista da Marginal Tietê e do Rodoanel em seu conjunto. Tanto a lógica do funcionamento do sistema, ou seja, "conter" as inundações, como a lógica das compensações ambientais, sem as quais os financiamentos não acontecem, são explicadas no interior da acumulação de espaço.

Cabe aqui uma observação técnica, mas com alguma relevância para este debate. A criação do Parque tem pouca ou nenhuma influência para diminuir as inundações a jusante. Como já foi dito anteriormente, as alterações propostas pelas obras hidráulicas em concomitância à urbanização modificaram significativamente os mecanismos de escoamento, o que torna as inundações um problema bastante compartimentado e localizado cujas subbacias e bacias maiores apresentam dinâmicas intrínsecas que se explicam em variações de meso-escala a escalas locais. De modo mais simples, não é necessária pluviosidade em todo o Alto Tietê para ocorrer pontos de alagamento ou extravasamento do escoamento do canal em áreas da bacia do Pirajuçara ou do Aricanduva, por exemplo. Pluviosidades muito excepcionais acarretariam vazões muito elevadas no Tietê, fato que poderia dificultar a vazão de seus tributários. Mesmo assim há pouca influência do Parque em relação às inundações. É dessa maneira que operam os discursos, ao impor necessidades técnicas desnecessárias por representações criadas em meio às 
inseguranças também produzidas no discurso. No centro dessa questão técnica a ideia é preservar a Marginal Tietê manter a circulação viária. Contase também para isso com a operação da Barragem da Penha que impede o escoamento fluvial de montante, como o ocorrido no verão 2009/2010, as águas que escoaram das barragens da cabeceira do Alto Tietê (e não a água da chuva) refluíram para o Pantanal a partir de seu barramento na Penha.

Outra coisa é o perímetro do Parque relativamente às expropriações. Quando visualizamos uma imagem de satélite da região ou o próprio perímetro institucional do Parque (Ver: Anexo III: Perímetro Parque Várzea do Tietê Departamento de Águas e Energia Elétrica do Estado de São Paulo - DAEE) percebemos que há uma grande área livre disponível e permeável que já serve de amortecimento, se fosse esse o caso.

Alguns moradores, via Conselho Gestor do Parque, questionaram a inclusão de conjuntos de moradias dentro desse perímetro. Eles mesmos percebem a desnecessidade da inclusão sistemática de milhares de famílias dentro do perímetro previsto, num jogo que não compreendem, e que é jogado justamente nesse sentido, tornar-se incompreensível e justificar-se nesses termos. Para tanto, elaboraram um documento que encaminharam ao Departamento de Águas e Energia Elétrica do Estado de São Paulo (DAEE) para solicitar a revisão do perímetro. Outras situações vividas pelos moradores também são citadas neste documento, as que estão no âmbito da informação, da clareza, do acesso desses moradores às instituições. O documento é reproduzido na íntegra abaixo ${ }^{96}$ :

Movimento de moradores da Várzea por justiça no Processo de Desapropriação

Ref.: Garantia dos Direitos Fundamentais, diminuição do limite de desapropriação e da dignidade dos moradores da Várzea do rio Tietê

Ao DAEE - Departamento de Água e Energia

Desde o lançamento do Parque Linear Várzea Tietê no Parque Ecológico em 2008 pelo Governador José Serra, nós moradores organizados nos movimentos e entidades que atuam na região por justiça e pelos direitos no processo de

${ }^{96}$ Somente a formatação foi modificada para integrar-se a este texto. O texto do documento este em itálico para efeito de distinção. 
remoção/desapropriação em relação à construção da Via Parque estamos sem informações concretas em relação ao projeto, o qual têm acarretado vários problemas à população que será diretamente afetada.

Temos acompanhado o processo de implantação da obra e percebido a aflição das comunidades da Várzea devido à falta de definição dos estudos para a implantação do Parque, a não apresentação de propostas para as famílias que terão que sair e o real limite de desapropriação/remoção.

Depois de organizarmos várias reuniões, Assembleias populares com a presença do poder público, participarmos de audiências públicas na Assembleia Legislativa, reuniões na DAEE, no Ministério Público, na Defensoria Pública, na Secretaria de Habitação do Estado e do Município (CDHU e SEHAB), manifestação e Audiência Pública com o Prefeito Gilberto Kassab e não obtermos um resultado ao encontro dos nossos anseios que superassem as nossas expectativas encaminhamos este ofício com alguns pedidos conforme consta no Plano Diretor de Reassentamento, o qual o BIRD- Banco interamericano de desenvolvimento fez algumas recomendações: ${ }^{* * * *}$

- Que o Governo através das Secretarias e departamentos envolvidos faça várias reuniões e audiências com a população que será afetada para prestar esclarecimentos sobre a construção do projeto;

- Que para o início das obras, haja a definição exata do limite de desapropriação; *******

- Que haja a definição da política que será adotada para a retirada das familias, antes de começar qualquer tipo de ação em relação à desapropriação e remoção.

- Que desenvolvam um projeto de minimização de impacto de enchentes e barreiras de contenção evitando assim desalojar muitas famílias.

Sabemos que nenhumas destas exigências feitas pelo Banco financiador estão sendo cumpridas. $O$ que temos visto são funcionários da SEHAB e a empresa DIAGONAL fazendo vistorias e o "convencimento" de forma imperceptível na região. Diante disto estamos empenhados por justiça no processo de remoção e desapropriação, seguem nossas propostas:"

- Pela presença da DAEE e de todas as Secretarias envolvidas no projeto para dar melhores esclarecimentos sobre a construção do Parque e o estudo definitivo, o limite de desapropriação, o estudo de impacto ambiental EIA-RIMA, as empresa envolvidas e a política que o Governo adotará de fato para a remoção e desapropriação.

- Pela diminuição do limite de desapropriação. Salientando que é possível a redução de risco na região.

- Por uma justa indenização das famílias que serão removidas ou desapropriadas com um valor significativo que garanta a compra de outra casa.

- Por um projeto de legalização e urbanização no bairro que garanta o desenvolvimento sustentável através de políticas públicas de saneamento básico e outros.

- Pelo desassoreamento de fato do Rio Tietê e construção de barreiras de contenção contra enchentes. 


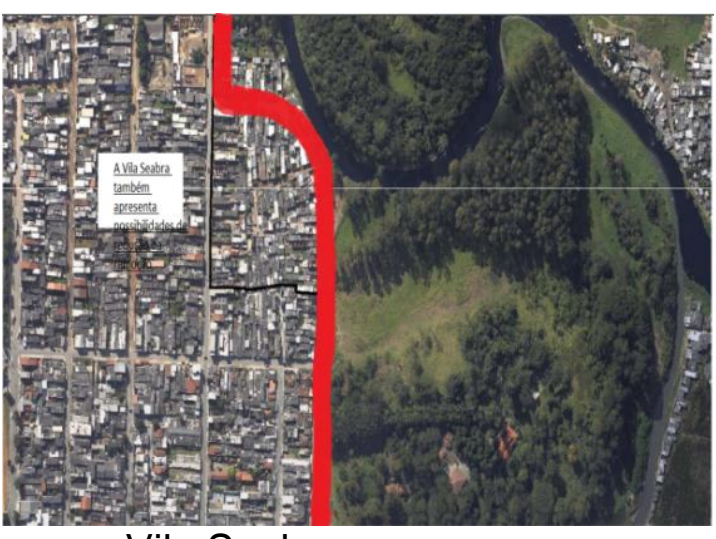

Vila Seabra

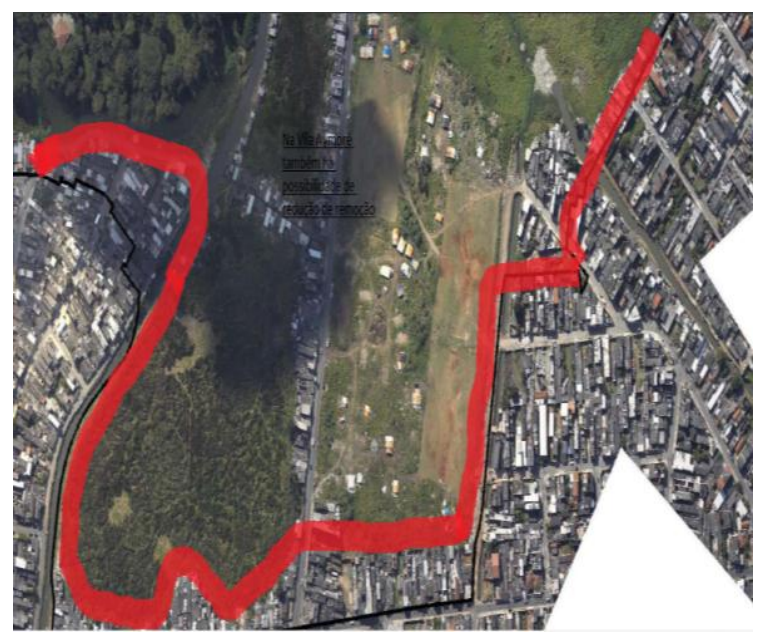

Bairro Aymoré

Jardim Romano (abaixo)
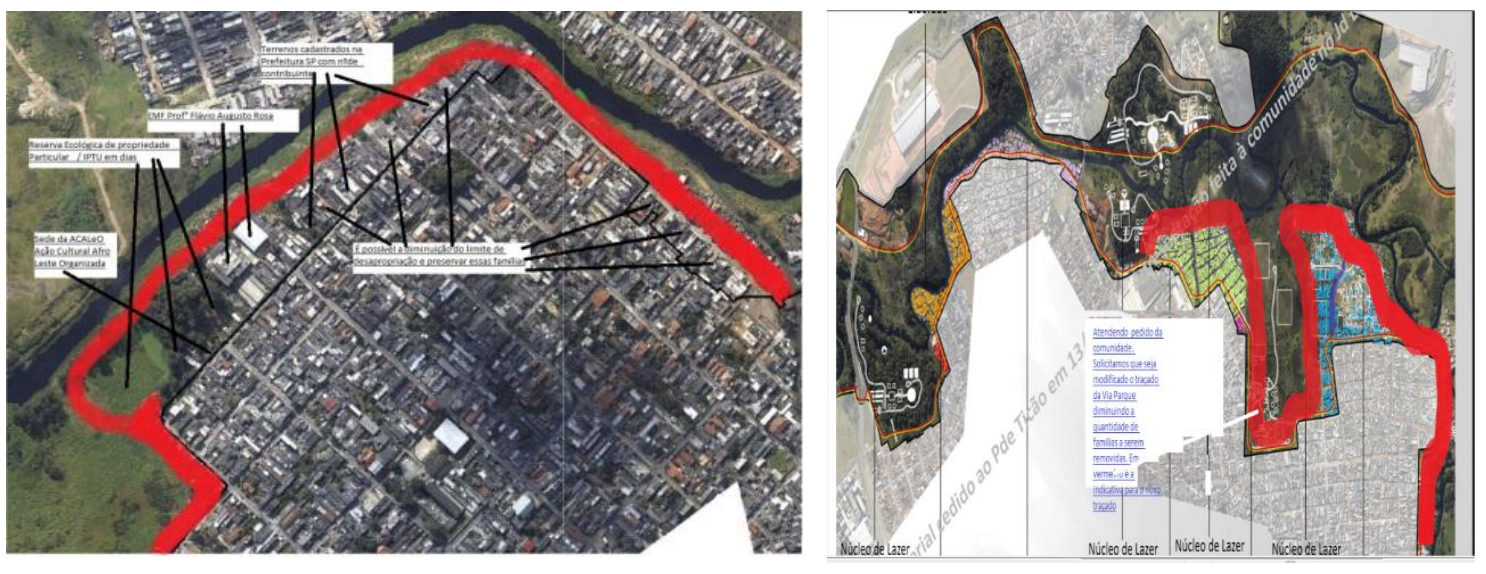

Jardim Pantanal (aciam)

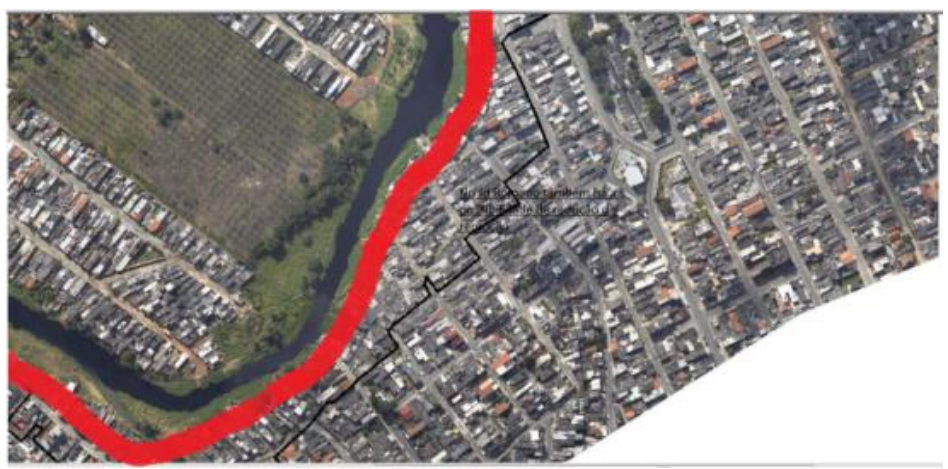

Vila Itaim 
As imagens acima acompanham 0 documento elaborado pelos moradores, os quais a diminuição do perímetro do Parque (linha preta em destaque) pela exclusão de determinadas áreas (linha vermelha). É possível visualizar muitas áreas sem ocupação e permeáveis, o que nos leva a crer, assim como aos moradores, desnecessárias as remoções.

No entanto, tais formulações também coadunam com a lógica que perpassa toda a justificativa da construção do Parque, uma vez que a relevância das remoções se justifica nas próprias condições ambientais das várzeas do Tietê. $O$ ambientalismo é a justificativa das remoções por parte das instituições que representam o Estado e grupos privados, ao mesmo em que uma forma de solicitar a permanência de certos conjuntos de moradias por parte das instituições que representam os moradores, no caso, a representação dos moradores no Conselho Gestor do Parque.

As formas que perpassam a lógica de inserção dos moradores na luta por sua permanência na região são institucionalizadas-institucionalizantes, pois que definem a condição na qual estes devem conduzir suas reinvindicações juntos aos órgãos oficiais. Essa lógica conduz aos moradores para as formas institucionais pressupostas sem o que estes não atingem o campo das "negociações". Vão se constituindo as representações do espaço também no campo de luta por essa via da institucionalização dos movimentos como via única do "diálogo" possível. Nessa forma caminham as muitas formulações e questionamentos relativos ao conflito.

O Conselho Gestor na representação dos moradores destaca também neste documento outra questão relativa à inundação que em nenhum momento é mencionada como problema pelas instituições, mas que contribui com a frequência e intensidade das inundações, que é o assoreamento. Pessoas ligadas aos movimentos dos moradores, Wagner (Movimento Unificado de Luta no Pantanal) e Oswaldo (Instituto Alana e representante popular no Conselho Gestor do Parque), disseram que fazia mais de dez anos que as instituições não desassoreavam os rios da região. Com as pressões populares e 0 descalabro das inundações de 2009-2010, aconteceram desassoreamentos a partir de 2011 e uma quantidade significativa de material foi retirado. 

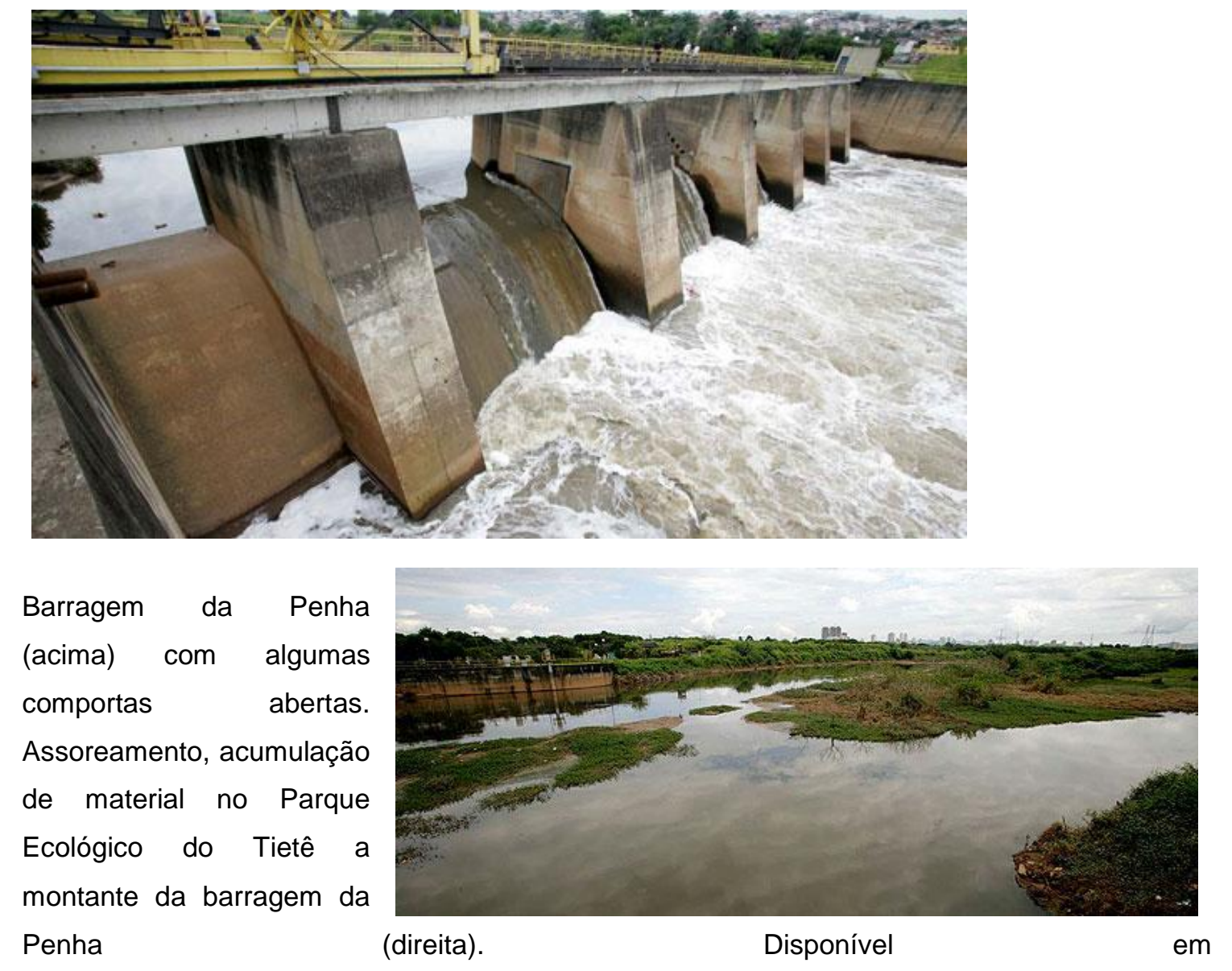

http://noticias.uol.com.br/cotidiano/2009/12/17/ult5772u6678.jhtm acesso 06/08/14.

Abaixo à esquerda (em destaque), caraças de automóveis retiradas do rio no processo de desassoreamento (foto do autor, junho/2014). À direita, carcaças e sedimentos acumulados no leito do Tietê antes do desassoreamento (imagem cedida pelo Instituto Alana (s/d).

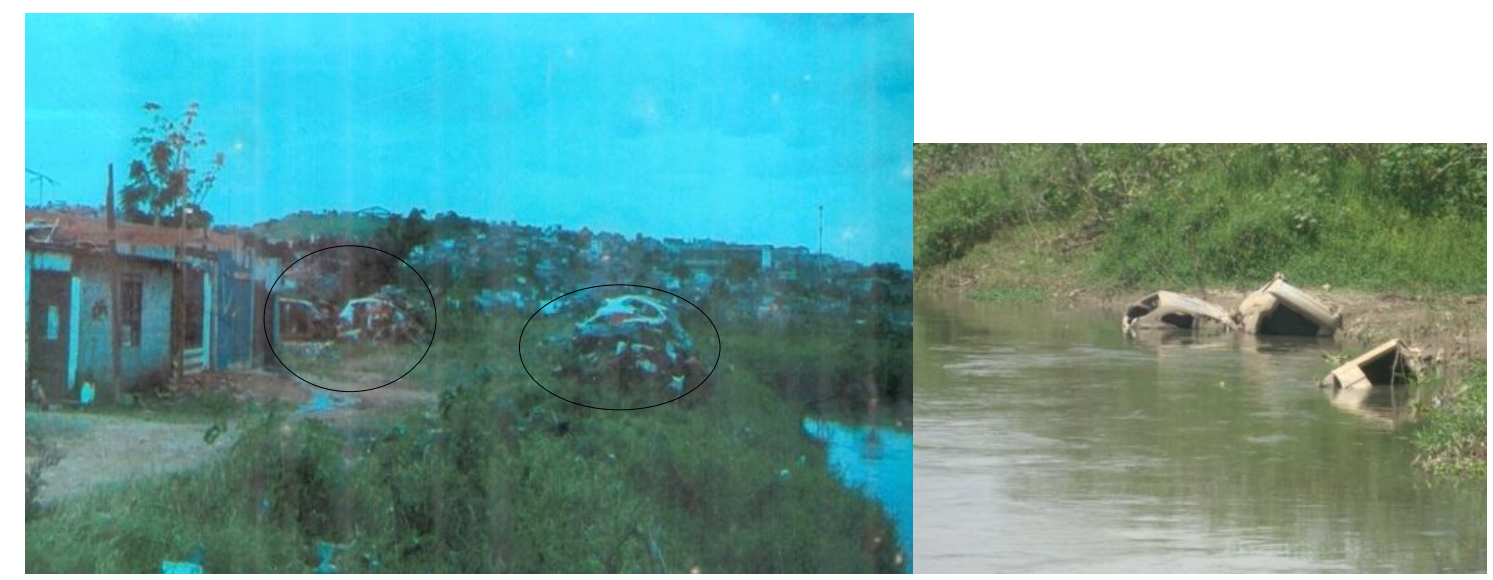


É importante que se diga, as mudanças nos talvegues podem intensificar o assoreamento a partir da própria carga natural do rio, principalmente em caso de barragens, como é, para o Pantanal, a Barragem da Penha, um agente intensificador desse processo e, consequentemente, das inundações:

[...] deve-se observar, ainda, que 0 assoreamento se dá quando o curso d'água não tem capacidade de transporte, o que acontece principalmente em cursos de baixo gradiente, ou ainda por redução da superfície de infiltração (desperenização dos rios), bem como por elevação do nível de base por construção de barragens (CASSETI, 1991 p. 74).

Por essas desconstruções das justificativas da criação do Parque fica a questão: então a que serve tudo isso? Por essa questão é que torna-se imperativo transcender o espaço como objeto concreto para pensa-lo nas e pelas relações que aqui se constituem nos diferentes níveis e dimensões do processo (LEFEBVRE, 1999) ${ }^{97}$ que se põem como condição do espaço enquanto realização destas mesmas relações, as quais envolvem o próximo e o distante no território onde se confrontam ao cotidiano dos moradores as necessidades de realização das esferas financeiras mundializadas do capital e o Estado como poder político e regulador dessa realização, conforme proposto no próprio Plano de Reassentamento:

O arcabouço jurídico disponível na legislação ordinária respalda amplamente a realização das ações previstas no Programa, além dos municípios terem competência para o ordenamento territorial 0 que inclui a formulação de instrumentos jurídicos específicos (lei de expropriação, decretos etc.) (SÃO PAULO, 2010a p. 22).

A demarcação territorial da legislação ambiental não é mera remoção de populações e estabelecimento de políticas de reassentamento, e sim uma condição estratégica definida num dado espaço no interior do qual as formulações políticas e econômicas de realização da economia financeira se tornam potenciais. No entanto, para essa realização cabem outras lógicas, as da ordem subjetiva que capturam a consciência social, operam-na como mistificada (LEFEBVRE, 2008). É nessa lógica que trabalham as

\footnotetext{
${ }^{97}$ Henri Lefebvre propõe como análise do espaço a ação de diferentes níveis e dimensões que se definem no e pelo espaço a partir de relações que variam das mais abstratas, por exemplo, no nível do Poder, do Estado e das estruturas privadas por este dinamizadas a partir das sóciológicas pressupostas pelo que o autor chama de neodirigismo, passando pelo nível "especificamente urbano", no qual se relacionam os lugares e as instituições, e o nível mais particular definido pelas relações habitar-habitat, condicionadas pela escala da prática cotidiana, mas tensionada pelas abstrações mundializadas (LEFEBVRE, 1999 p. 77-98).
} 
representações do espaço. Tal construção se faz de maneira direta e objetiva no Pantanal ao criar uma fantasmagoria que ao mesmo tempo afirma e nega as condições legitimadas nas e pelas ações propostas nos planos de construção do Parque. Esse jogo dispõe uma formulação política aos moradores cuja exposição nunca se elucida, se apresenta sempre velada, esclarece pelo obscurecimento, o que, tomando emprestado a Henri Lefebvre, podemos chamar de presença-ausência, a qual não é somente das entidades mas mesmo do espaço em si, ali está mas não pode ser alcançado.

A própria violência desse processo não é direta nem simbólica, e são as duas coisas ao mesmo tempo. Algumas das tramas contemporâneas da produção do espaço aparecem como soluções e compreensões do processo social, mas, em certa medida, expõem a problemática contemporânea de sua produção desigual. Quanto mais se define como objetivação, mais se realiza como ficção, não somente pelo suporte fictício do capital financeiro, mas por sua forma velada que aparece como representação do espaço e se faz nos moldes impostos pelos discursos produzidos e reconhecidos socialmente, cuja objetivação torna-se o próprio espaço de representação. Tal lógica opera no nível mais cotidiano não somente nos elementos objetivos, como a moradia, mas também na subjetividade, como no desejo. 

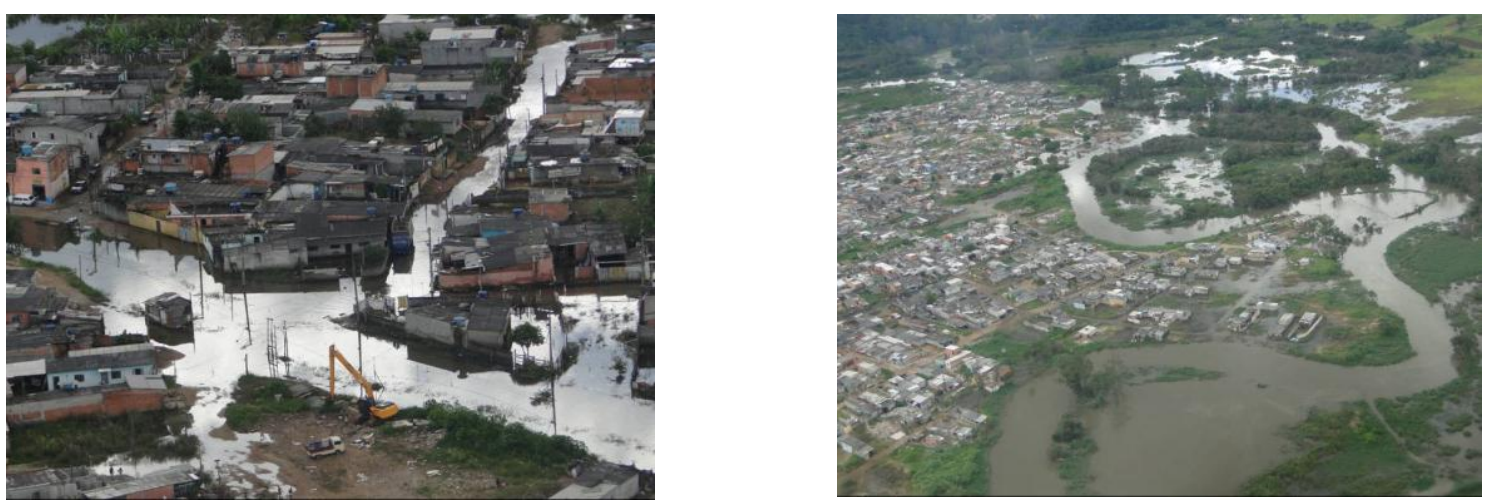

Acima, imagens da inundação de 2010 (direita) que durou 54 dias e a de 2011 (esquerda) que durou 5 dias (imagens cedidas pelo Instituto Alana).

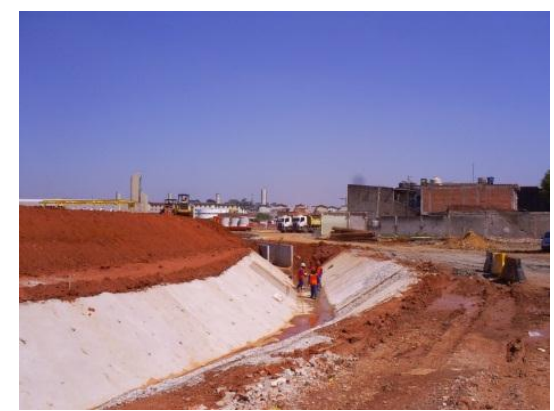

Acima, construção do Dique do Jardim Romano em 2011 (imagem cedida pelo Instituto Alana)
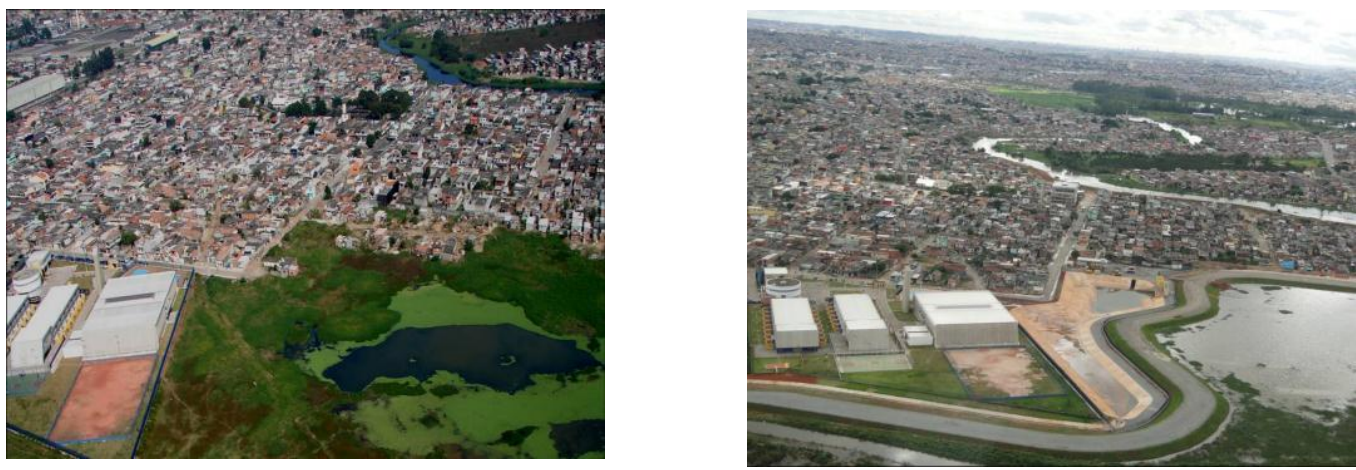

Acima (esquerda) Centro de Educação Unificado (CEU) Curuçá (estrutura em primeiro plano à esquerda) e Jardim Romano (ao fundo) em maio às lagoas do Tietê. À direita, o mesmo cenário após a construção do dique do Jardim Romano em 2011 (imagens cedidas pelo Instituto Alana). 


\section{Capítulo $\mathrm{X}$ \\ O Pantanal em SI}

Minha primeira visita ao Pantanal da Zona Leste foi a uma das localidades, a Chácara Três Meninas, onde ocorreram várias remoções. Aconteceu no mês de maio de 2012. O primeiro contato que fiz foi com Maria Zélia de Sousa Andrade, ou somente Zélia que faz parte do Movimento de Urbanização e Luta do Pantanal (MULP), contato sugerido pelo colega João Vitor, cujo Trabalho de Graduação Individual em Geografia e também a atuação política se desenrolam na área do Pantanal. Combinamos (eu e Zélia) por telefone, quando ela me passou as coordenadas para chegar ao local. Nunca havia ido de trem além da USP Leste. Das Clínicas onde eu estava até a estação Jd. Helena/Vila Mara foi 1h e 30 de percurso. Da estação Brás até lá, 40 minutos. A desembarcar na estação, percorri a pé as ruas do Jd. Helena até a Chácara. Do alto da estação via ao longe duas torres de uma igreja que não me preocupei em saber o nome, para onde a rua em frente à estação levava. Essa imagem em perspectiva ampliava a sensação de lonjura. Ao caminhar pelas ruas percebi que essa perspectiva se produzia pelo desenho do arruamento, um tabuleiro de xadrez clássico, a simetria na qual, na qualidade de estranho, eu poderia tanto me achar como me perder. Procurava as torres da igreja como marco de meu caminho, e lá fui.

Casas térreas na maioria, mas muitos sobrados, uma ao lado da outra, muitas com recuo lateral, outras tantas não, quase todas bem acabadas, sinal de muitos anos de construção, nenhum prédio a não ser um conjunto habitacional próximo à estação de trem, nenhum terreno vazio, ao menos naquele trajeto. Me pareceu um lugar de muitos anos, três décadas talvez, desde os primeiros loteamentos. Uns comércios, serviços, uma escola franquia de uma grande rede (assim como os hambúrgueres, quem diria) próxima à estação, mercadinhos, bares de variados gostos, desde aqueles do churrasquinho na calçada aos equipados com muitas tevês de plasma, ou LCD, sei lá.

Tive essa sensação na volta, mas acho que vale dizer que, acostumado às cabeceiras do Pirajuçara desde sempre, aos relevos acidentados da área 
sudoeste da metrópole, e mesmo outras, as colinas abruptas das margens esquerdas dos rios Pirajuçara, Jaguaré, Morro do $\mathrm{S}$, Boçucaba, os da confluência interna Tietê Pinheiros, os vales encaixados das cabeceiras, ladeiras, subidões, escadarias, enfim, me era muito diferente, estranho todo aquele trajeto. Não imaginava São Paulo a partir daquela topografia, a planura insistente que por 40 minutos de caminhada multiplicava as perspectivas do imenso tabuleiro de xadrez. Pensei nos objetos que fazem parte das construções do realismo fantástico de Borges, o xadrez, o labirinto, nos quais, simultaneamente, agora eu caminhava. Pensei também que aquela paisagem eu havia visitado em outras cidades, que de meu vivido aqui nesta metrópole ainda me eram desconhecidas.

Encontrei Zélia em frente à escola pública Eckhio Tavares, na Avenida Dr. José Artur Nova. Essa avenida é um "limite" entre o que são os loteamentos propriamente ditos e as áreas ocupadas. Daí em diante, a paisagem muda, o asfalto avança somente alguns metros, e a maior parte do arruamento a partir de então é de terra. $O$ asfalto também tornou-se referência para Zélia ao mencionar o Pantanal. É nítido que, quanto mais adiante, em direção ao rio, mais o casario se modifica. Próximo ao asfalto, que parece mais consolidado e, novamente, com mais tempo de ocupação, as casas parecem mais acabadas, algumas já com dois andares, umas poucas com um terceiro.

Ao chegar à margem do rio Tietê, me pareceu que tudo se modifica. Primeiro o cheiro desagradável do rio, estreito e profundo, de uma coloração que mistura sedimentos e matéria orgânica. No trecho da rua em que estávamos, paralela ao rio, havia casas dos dois lados, ou seja, as do lado de lá faziam fundos com o próprio rio. O casario, ou grande parte dele, era construído com uma parte de alvenaria outra de materiais improvisados, outras até quase totalmente deste último tipo: madeiras de diversos tipos e tamanhos, placas de sinalização, telhas que cobriam as fachadas, telhados baixos, portas em retalhos de madeira. A essas, por hora, chamarei de muito precárias.

É nesta área à margem do rio, nas ruas paralelas a este que se situam as demolições, a desoladora terra arrasada sem a qual não se conta a história desta metrópole. Os escombros cobriam o chão das ruas, assim como eram usados por outros moradores como aterro. Assim que os moradores aceitam determinada forma de "compensação" por suas moradias (assunto que trato 
mais adiante), estas são demolidas. Fica a mensagem em meio aos escombros, subliminar e ao mesmo tempo concreta, o fantasma que passa a assombrar aos que ficam, como sinal de seu futuro. Observei em alguns "restos" de construção pisos de cerâmica, azulejos nas paredes, sinais de uma construção que se arrastou por anos, pois tais matérias de acabamento são, na maioria das vezes, os últimos a serem colocados.

Um detalhe que me chamou a atenção, que diz respeito ao discurso da sobre a necessidade de preservação das várzeas e a permeabilidade do solo. As demolições deixam o chão impermeável, não retiram o piso construído pelos moradores, ou seja, a preocupação é remover as populações e não restaurar as "qualidades ambientais" da várzea.

Zélia me contou que algumas dessas áreas que estávamos já haviam sido desocupadas antes, mas que muitos moradores voltaram, pois não obtiveram outra moradia para se situarem, a não ser um alojamento para onde foram levados por volta de 1996 (na primeira grande tentativa de remoção para a consolidação do Parque) e lá ficaram em condições que muito lembram os cortiços, no entanto, sob as rédeas da institucionalização. Anos mais tarde, voltaram, uns, depois outros, tornam a construir tudo do zero, e logo a paisagem passa a ser a mesma de antes. Catorze anos depois, novamente o conflito, a inundação, as remoções, os cães, as bombas os tratores. A fantasmagoria é uma presença insólita na vida dos que resistem, não sabem se virá sua vez de partir, e dos que se vão, não sabem para onde vão, não sabem se vão voltar.

Na visita que fiz em junho de 2014 junto com a Professora Amélia Damiani e a turma da disciplina Trabalho de Campo em Geografia algumas áreas das quais os moradores haviam sido removidos a partir de 2010, assim como suas casas "varridas", começavam a ser ocupadas novamente. Materiais improvisados, lonas, placas de sinalização, pedaços de madeira, alvenarias, partes de automóveis, tudo é válido para este retorno, ao mesmo tempo tudo é fantasmagórico, tudo é negativo.

A forma que permeia este capítulo, a fantasmagoria, desafia a análise, se apresenta e se oculta no tempo e no espaço, horas é virtual, horas é objetiva. Num espaço de dois anos, quando fiz a última visita, os cenários eram muito diferentes. Saber a que serve o conflito é antes de tudo, me parece, 
saber que este se apresenta como acumulação de espaço. No entanto, há polos antagônicos que se defrontam no e pelo espaço como lugar do conflito. Essa análise se cria num contexto que faz parte das apreensões e percepções na busca pela realidade como processo a ser desvendado, ser lido para além da forma. A produção do espaço é um momento político? É um momento da política? É uma simultaneidade de forças? O campo de luta dessa objetivação é concreto-abstrato, visível-invisível, próximo-distante. As representações dessa lógica espacial obscurecem o real pelo dilaceramento do vivido. Ao chegarmos a essa dimensão, se apresentam as formas como se encaminha a produção do espaço, a expropriação velada pelas representações como forma social necessária.

A produção do espaço como uma apreensão epistemológica da Geografia pressupõe uma integração entre diferentes escalas territoriais conduzidas objetivamente, mas que permeadas por modos de ser e de pensar que refletem sua representação enquanto objetividade. Dessa maneira, pensála significa que tais relações se apresentam contraditórias pela forma em que se defrontam os agentes dessa produção, aqueles externos ao espaço mas que para ele convergem suas formas político-econômicas, e os que nele vivem, tenho os chamado moradores, que são internos ao espaço mesmo, que dele e por ele se apropriam como cotidiano, seja pela fruição, seja pela precariedade, ou ambos, também como conflito que revela o lugar como uma unidade que integra e expressa espaço e tempo.

Espaço-tempo-lugar como conflito que se desdobra ao defrontar uns e outros quando se intenta re-produzir o espaço sob uma ordem geral que expressa as relações abstratas da reprodução contemporânea. Essa contradição se objetiva no espaço de luta, o Pantanal, não mais ao pôr e dispor o espaço enquanto simultaneidade, como forma desigual e desigualmente produzida da mesma maneira que em tempos atrás quando a urbanização refletia o legado industrial da reprodução da força de trabalho.

Os tempos são outros e, conforme Amélia Damiani, "não há urbano para todos" (DAMIANI, 2000, op. Cit.), o que nos leva a repensar as contradições deste espaço que é o Pantanal sob novas lógicas que operam não somente o cotidiano como espoliado, mas a expropriação em si, a destituição do urbano aos moradores. 
Repensar este processo não significa refazer as categorias de análise, mas entender as formas como estão tensionadas. O espaço se afirma como elemento da reprodução de maneira que a lógica da expropriação que historicamente opera, sobretudo, na formação de capital ainda se faz lógica e prática, mas se dispõe atualmente para outros modos em que a reprodução produz o espaço, não mais como produtor e produtivo, mas como uma forma disposta à realização de derivações da mais-valia em escala mundial e, mais ainda, da acumulação fictícia global em rendas e principalmente juros, ou seja, o espaço predisposto à realização financeira como aprofundamento da relação capital-espaço. Se há tempos, irregular, precário e ilegal eram formas necessárias à reprodução do proletariado, o que constituiu o espaço desigual e desigualmente produzido, torna-se imperativo à reprodução contemporânea recorrer a este processo que condiz e conduz à financeirização. Refaz-se também o discurso, não como expropriação aberta e desvelada, mas obscurecida por outras ordens, a da sustentabilidade e da sociedade de risco entre elas.

No Pantanal da Zona Leste de São Paulo a produção do espaço incorpora um jogo que pressupõe estratégias e ideologias que perpassam os diversos espaços de seus moradores, do corpo, da moradia, do entorno, do desejo, da afetividade, enfim, opera subjetiva e objetivamente a partir das formas contemporâneas de representação. Perpassa também uma prática a partir da operação do Sistema Alto Tietê. A forma finalizada seria a própria representação social, o Parque Várzea do Tietê, a forma abstrata que obscurece pela via sócio-lógica as contradições na luta pelo espaço no Pantanal da Zona Leste.

No interior desse conflito opera também a categoria da propriedade privada que realiza a costura final ao dispor para o concurso da produção do espaço a forma lógica da acumulação de espaço pela via da expropriação de parcelas da superfície terrestre. A propriedade aparece em "camadas", como nos fala Ricardo Baitz (BAITZ, 2010) que permitem sua mutação de maneira que possa ser solicitada em socorro à reprodução. Em nosso caso, a institucionalização como representação do espaço é a via pela qual se faz o percurso da moradia à expropriação para apreensão de como opera uma parte da lógica da reprodução contemporânea. 
A área do Pantanal que correspondente à Zona leste de São Paulo situa-se à margem esquerda do rio Tietê, mas as moradias se estabelecem em ambas as margens deste por vários municípios. Trata-se de uma área extensa que se inicia num ponto importante como estrutura técnica, que é a Barragem da Penha, construção que permite o controle da vazão do Tietê à jusante. Esta barragem encontra-se numa área de legislação própria já definida a partir dos diversos mecanismos de restrições ambientais previstos na lei de criação do Parque Várzea do Tietê (Lei 5598 de 1987), que é o Parque Ecológico do Tietê. A montante deste começam as moradias e outras formas de uso, como fábricas (como a fábrica Nitroquímica $S / A$, entre outros) e áreas de uso institucional (um exemplo é o Campus Leste da Universidade de São Paulo USP Leste).

Por sua extensão, o Pantanal abrange diversos logradouros, tais como Chácara Três Meninas, Jardim Pantanal, Jardim Romano, etc. Conforme os moradores são dezessete bairros ao todo. A história de sua ocupação como moradia também possui diferenças no tempo e no espaço, assim como as formas de expropriação. Com base numa conversa que tive com um antigo líder comunitário, Ronaldo Delfino (que atualmente não mais habita a região), as primeiras remoções que aconteceram com a construção do Parque Ecológico do Tietê já se ligavam às políticas viárias, pois a construção da Rodovia dos Trabalhadores, atualmente conhecida por Rodovia Ayrton Senna (liga, via Marginal Tietê, o município de São Paulo ao Vale do Paraíba), já havia propiciado a remoção de muitas famílias nas várzeas do Tietê nas proximidades da Barragem da Penha, isso nos primeiros anos da década de 1980, fato que corrobora coma afirmação da ocupação desde a década de 1970. Outro morador e líder comunitário, Sr. Luisão, em sua fala no 3ํo Fórum do Pantanal (15/06/12), contou que algumas áreas no Pantanal foram ocupadas por moradias ainda em fins da década de 1970, que os aterros do Jardim Helena começaram por volta de 1978, que este bairro se formou há mais de 40 anos. Enfim há vários relatos de vários momentos diferentes para lugares diferentes ao longo da várzea do Tietê.

Sr. Luisão, por exemplo, mora há certa distância do rio. Os primeiros terrenos ocupados guardavam essa distância, que foi se consumindo ao longo da ocupação, fato que resultou em uma proximidade cada vez maior com o rio 
para o caso dos moradores que ocuparam a área mais tarde. A própria condição de proximidade ou não ao rio Tietê é uma variável da ocupação. Trata-se da superfície de inundação e diz respeito aos que nela vivem e compartilham tal problema. É ainda o mais precário, aonde alguns serviços como água e asfalto não chegam porque são proibidos. É assim, a área institucionalizada, proibida para moradia e ao mesmo tempo morada de muitos. Porém, é também o conflito, o envolvimento de grupos de moradores nas tramas da expropriação.

Esse fato expressa uma fragmentação vivida que perpassa a percepção dos moradores da várzea do Tietê, os quais, embora com histórias comuns, passam a se diferenciar. O Pantanal, sua definição enquanto pertencimento passa então por um processo que envolve o dentro e o fora, o eu e o outro. As gradações na paisagem correspondem às da percepção, "o Pantanal é lá", "é onde tem enchente", "é onde o governo está tirando as casas" 98 . São as falas de alguns moradores do Jardim Helena que habitam nas proximidades da Linha 12 da CPTM que faz o percurso Brás-Calmon Viana, ou linha do trem como preferem aqueles, a qual percorre os terraços relativamente enxutos cuja morfologia plana acompanha o traçado dos terraços fluviais ("fill terraces" segundo Ab'Saber, 1957) abrigados das inundações. Esta área dispõe de estruturas urbanas e não se enquadra nos limites institucionalizados da várzea do Tietê. Foi a partir da linha do trem em direção ao rio que seguiu o fatiamento do solo. Há, portanto, uma história comum da ocupação das várzeas do Tietê, mas que se diferencia na lógica das formas de reprodução. A produção desigual do espaço expressa uma profunda fragmentação que se reflete na própria fragmentação social.

Para remontarmos um pouco a ocupação da região recorremos a alguns relatos como este divulgado no site do Coletivo Liberdade Socialista, de março de 2009:

O Pantanal localiza-se na zona leste da capital de São Paulo, à margem esquerda do Rio Tietê, no Distrito do Jardim Helena, em São Miguel Paulista. A região está a 30 quilômetros do centro de São Paulo. Como o próprio nome revela, antes da ocupação por moradores sem teto e por outros sem condições de pagar aluguel, o local inundava toda vez que chovia muito.

${ }^{98}$ Falas que pude acompanhar em um campo realizado no Pantanal em 01/06/2014 pela disciplina Trabalho de Campo em Geografia com a Professora Amélia Damiani. 
As inundações ainda acontecem, mas não com a intensidade de antes.

A região começou a ser formada com os contornos de hoje em 1986. Na ocasião, o então governador de São Paulo, Orestes Quércia, reintegrou uma área ocupada no Itaim Paulista, também na zona leste de São Paulo, e levou as duzentas famílias dali para as proximidades do Pantanal. Em um ano, no local já havia mais de 3.000 famílias. Os movimentos de moradia aproveitaram a onda e ocuparam às outras áreas ao longo da margem do rio. A área específica do Jardim Pantanal começou a ser ocupada em 1989.

Atualmente em toda a região existem cerca de 25.000 famílias. Isso significa quase 100 (mil) pessoas vivendo em uma área com oito quilômetros quadrados. São poucos os moradores que trabalham com carteira assinada. A grande maioria está desempregada ou trabalha em empregos precários: catadores, camelôs, empregadas domésticas e outros ${ }^{99}$.

Em outro relato, que procura resgatar a história da formação do Jardim

Pantanal, as ocupações se intensificam na segunda metade da década de 1980:

As famílias da Zona Leste, principalmente de São Miguel Paulista e Ermelino Matarazzo, sendo despejadas de suas moradias por não terem condições de pagar os alugueis, e organizadas em movimentos de moradias, vendo que não houve repressão nas ocupações dos mananciais da represa de Guarapiranga e Billings, deram início às ocupações nas várzeas do Rio Tietê, começando pelo terreno do Parque Ecológico do Tietê, região onde o rio havia sido retificado desde à Nitro-química até a Barragem da Penha possibilitando assim, o acesso de caminhões com aterros para a várzea do rio que hoje denomina-se União de Vila Nova e tem em torno de 8.000 (oito mil) famílias.

No início da ocupação o poder público estadual entrou com um processo de reintegração de posse, mas não teve êxito porque o Estado não era o proprietário da terra. Em 1988 foi criada a lei estadual que regulamenta as Áreas de Proteção Ambiental do estado de São Paulo e o terreno foi aí enquadrado, mesmo esta não tendo uma definição perimetral exata.

Em 1989 o movimento de moradia da região de São Miguel, começa a organizar um grupo para liderar a ocupação do Jardim Pantanal, sendo que a primeira região a ser ocupada foi à área que compreende as ruas Tietê, Manima, Cosme dos Santos, Árvore do Papel e Pinha do Brejo, que segundo a coordenação do movimento, pertencia uma parte à Marinha e outro ao Banco Itaú.

Em meados de 1989 começa a demarcação dos terrenos pelas ruas Erva do Sereno, Samôa Ocidental, Dom Miguel de Bulhões e Rua Caninana, mas no processo da ocupação não

${ }^{99}$ http://www.Isr-cit.org/movimentos/46-movimentos/462-jardim-pantanal-uma-referencia-na-lutapor-moradia-na-cidade-de-sao-paulo. Acesso em março de 2012. 
houve uma preocupação com um cadastro das pessoas pra saber se haviam pessoas se apoderando de mais de um lote de terra, e com isto várias pessoas ficaram com mais de cinco lotes. A área em que está instalado o Instituto Alana foi ocupada por último, pois o local era guardado por um caseiro, que era mantido pelo dono do terreno.

Os anos de 1990 e 1991 foram de construção de casas, abertura e aterramento das ruas, pois eram grandes as dificuldades de conseguir água potável, energia elétrica e, principalmente, a evacuação dos detritos de esgoto - que no início iam para o meio das ruas.

Até o ano de 1989 existia uma área verde, com campos de futebol e algumas lagoas, entre as ruas Tietê, Pinha do Brejo (antiga Rua São Paulo) e Árvore do Papel, mas com a necessidade de moradia da população desta área, e com os incentivos do movimento de moradia, a população não avaliou os riscos que correriam no futuro e construíram suas moradias neste local.

De 1989 a 1992 as casas foram construídas com muito sacrifício, mas as pessoas começaram a refletir se foi uma boa escolha, quando em 92 há a primeira enchente ${ }^{100}$.

Tais relatos explicitam por si um processo de luta pelo espaço, na convulsão dos embates sociais situados no plano da segregação espacial, das condições objetivas da propriedade privada e seus aportes jurídicos. Nos deparamos com uma população "itinerante" que, no interior da metrópole, busca um espaço de moradia definido por uma mobilidade espacial sempre a partir da ocupação de áreas vazias, seja num movimento particular, seja em conjunto com outras populações, organizadas ou não em torno de movimentos de moradia. Um espaço desigual e profundamente fragmentado se apresenta como processo histórico na metropolização.

O conflito para a remoção dos moradores da região do Pantanal por parte do Estado se inicia ainda na década de 1980, principalmente a partir da Lei 5598 - 1987, que cria o Parque Várzea do Tietê e, conforme dito anteriormente, define as áreas de preservação permanente como proibitivas à construção de moradias. A partir da década de 1990, os conflitos envolvendo a remoção de moradores das áreas de restrição impostas pela legislação passam a operar de maneira sistemática. E as grandes inundações tornam-se os momentos sistemáticos dessas formas operatórias, quando as atenções do Poder Público corroboradas com as das mídias de massa põem em evidência

\footnotetext{
${ }^{100}$ Documento cedido pelo Instituto ALANA: RESGATE HISTÓRICO DA COMUNIDADE DO JD. PANTANAL E OS PROCESSOS DE ENCHENTE NA REGIÃO - A RELAÇÃO COM O PODER PÚBLICO E O PROCESSO DE PARTICIPAÇÃO COMUNITÁRIO. S/D
} 
novamente a situação do flagelo. Vejamos trechos retirados do documento anterior:

[...] A vila foi crescendo e as pessoas foram acostumando com as frequentes cheias que ocorriam quase todos os anos até que, em janeiro de 1997, veio à grande enchente que dura em torno de 18 (dezoito) dias; as águas circulavam nas ruas e casas do Jardim Pantanal [...].

Secretário visita bairro inundado há 12 dias - Hugo Rosa, da Sec. De Recursos Hídricos do Estado, disse que vai sobrevoar região para descobrir origem das águas que cobrem Vila Pantanal, Zona Leste; moradores, desanimados, abandonam casas - "...Regional envia barcos para retirar flagelados."(Jornal O Estado de São Paulo - 15 de fevereiro de 1995)

Jardim Pantanal - entre a água e a lama, os Ilhéus da enchente. - "..."Um terreno num lugar seco pode custar mais de $\mathrm{R} \$ 10$ mil", explica o pedreiro alagoano Pedro da Silva. $\mathrm{Na}$ várzea do Jardim Pantanal não custava nada no tempo da invasão, em 1990. E tudo foi ocupado, apesar de ilegal, apesar do perigo. Surgiram assim, 15 bairros com cerca de 10 mil famílias. "Nem porco vive num lugar desses", diz Gabriel. Mas ele está hoje com mulher, cinco filhos, dois netos e dois cachorros no teto de sua terceira casa levantada em três anos." (Jornal O Estado de São Paulo - 2 de fevereiro de 1997) ${ }^{101}$.

Nesses momentos é que as lógicas contemporâneas da produção do espaço tornam-se potenciais e passam a operar, pois aparecem como soluções para o "flagelo" dessa população e se põem como justificativa para as remoções. Em uma conversa com outro líder comunitário, Oswaldo, em julho de 2012, período seco em São Paulo, este me falou que as pressões para a remoção haviam diminuído, pois é nos períodos chuvosos que elas aumentam em função das inundações. Dessa forma, as inundações passam a ser 0 convencimento social da remoção e ganham uma dimensão estratégica.

A ocupação do Pantanal data de fins da década de 1970, mas percebese que é nos momentos de inundação de vastas áreas da planície fluvial que passam a acontecer de modo sistemático as operações para a remoção da população, pois essa condição do ambiente fluvial das várzeas torna-se estratégica para os interesses em jogo. É a partir dessa situação que passam a operar também a insegurança, a incerteza, as pressões, o cotidiano tornado ficção. No entanto, elementos contrários à remoção também operam no jogo de forças, na forma das lutas por moradia em meio a processos de organização

\footnotetext{
${ }^{101}$ Idem, sem paginação.
} 
social em torno de movimentos populares para fazer frente à (des)informação do jogo político:

O ano de 1999 foi de intensa luta do MUP (Movimento Unificado do Pantanal) com os órgãos públicos municipais e estaduais, tentando barrar as remoções dos moradores das várias vilas do Pantanal. Mesmo com toda luta dos moradores do Pantanal, o governo conseguiu remover quase mil famílias para apartamentos da CDHU, no Conjunto Encosta Norte e Fazenda da Junta. E o pior foi que levaram as famílias para alojamentos de madeiras, com a promessa de construir as casas em um ano, o que não aconteceu. ${ }^{102}$

A questão dos alojamentos é retratada da pior maneira possível pelos moradores e pelos registros feitos, como é o caso do resgate histórico do Pantanal, no qual as formas de opressão postas a essas famílias nos alojamentos servem como pressão para o deslocamento, a desistência, enfim, tornam-se formas de desidentificação do morador com o lugar, a partir de um cotidiano oprimido pela institucionalização e meios de repressão que constroem a pura condição de ausência de direitos e de luta. É no confinamento nesses espaços que a ordem institucionalizada se define no controle dos horários, das visitas, da possibilidade de serem barrados nas portarias, no cotidiano vigiado e definido por normas, até que o próprio poder se torna ele mesmo definidor de outras formas de repressão além da mera institucionalização, como nos relata o trecho a seguir:

Depois da remoção das famílias, para os alojamentos dentro do terreno do Parque Ecológico do Tietê, e a demora para construção das casas e apartamentos, aconteceu muitas coisas no local como mortes, roubos, estupros e até expulsão de famílias inteiras de seus alojamentos, e também demorava muito o processo de urbanização que havia sido decretado sobre as vilas passíveis de legalização, como também não foi construído o parque nos locais que removeram as famílias, ficando como uso de varias atividades escusas, como utilizar os escombros para cativeiros de sequestros relâmpagos, desmanches de carros roubados, e tanto no Jardim Romano como na Chácara Três Meninas e no Cotovelo do Pantanal, o DAEE e CDHU, que fizeram todo processo, deixaram a maioria das paredes das casas que foram derrubadas pela metade. A população, que estava sofrendo todos os tipos de violências nos alojamentos e também nos apartamentos, vendo que já tinha passado três anos e nada tinha sido feito no local, começaram a voltar e reconstruir suas antigas moradias [...] e após mais um ano de o espaço ter sido desocupado houve um

102 Idem, sem paginação. 
processo de re-ocupação em massa perfazendo um total de 700 famílias só na região do cotovelo do Pantanal. ${ }^{103}$

Os métodos de convencimento e as promessas de outra moradia institucional são corroborados com as inundações. O cotidiano passa a ser institucionalizado no interior dos barracões do alojamento, sem deixar de situarse nas formas de segregação, nos mínimos, nas condições precárias as quais tal população é submetida. Mas a institucionalização tem também a forma política, a tentativa de barrar o movimento e a organização de luta por moradia. A segregação nos alojamentos torna-se forma de desarticulação assim como de convencimento para a busca de outras áreas de moradia, o que, neste caso, acabou por definir o retorno das famílias para o próprio Pantanal, mesmo com a premente condição das inundações, mesmo diante das formas precárias de moradia, mesmo com a ausência significativa de serviços básicos.

Os moradores voltaram, reconstruíram suas moradias, outros vieram com estes e novamente se instauram as moradias e o cotidiano no Pantanal da Zona Leste. É interessante notar que o processo de desocupação da várzea do Tietê é interrompido e mesmo não levado a cabo pelo Estado com a construção do Parque ou à conformação de um perímetro definitivo que possa resguardar os tais pressupostos de preservação conforme os termos da lei ${ }^{104}$. Isso acontece porque o território permanece sob o resguardo da legislação, pois sabe-se que mesmo se for ocupado já estará definido como irregular diante de pressupostos impostos anteriormente e dentro dos quais não se conforma nem a legalidade da moradia, menos ainda o acesso a certas infraestruturas urbanas de acordo com o previsto pela lei.

Veja-se que a formulação da lei de criação da Área de Proteção é de 1987 e somente dez anos depois houve uma grande operação de desocupação. Após longo período sem conflitos mais sérios (lembro que os conflitos são permanentes), as inundações do verão 2009-2010 trouxeram novamente a tensão na região. Fato é que os momentos mais prementes

\footnotetext{
${ }^{103}$ Idem, sem paginação.

${ }^{104}$ Conforme já dito anteriormente, as únicas áreas nas quais efetivamente alguma objetivação do referido Parque aconteceram foram o próprio Parque Ecológico do Tietê, ainda na remoção de populações para a construção da Rodovia dos Trabalhadores (atual Ayrton Senna) e o Núcleo Vila Jacuí do PVT como compensação ambiental de obras viárias como a ampliação da Marginal Tietê e o Rodoanel trecho Leste.
} 
dessa tensão entre moradores e instituições pela desocupação estão vinculados às situações de inundação.

Mas o território permanece como uma reserva, "congelado" por meio da legislação de restrição. Mais do que simples reserva, guarda a condição premente de tornar-se fiduciário de operações futuras e dessa forma seu tempo de "espera" na condição de congelamento permanece incógnito. Torna-lo uma representação do espaço por meio de instrumentos regulatórios aliados a ideologias é um momento necessário à sua destituição como moradia das populações empobrecidas. Por outro lado, as inundações parecem ser a forma mais acabada desse momento.

Embora a urbanização precária seja um processo dominante na metropolização de São Paulo, pela via da legislação que resguarda as várzeas do Tietê, tal precarização se aprofunda no Pantanal sob as variadas formas, expressas nas condições da moradia, na ausência de serviços, o que torna mais dramática a sustentação de um cotidiano quase ausente de objetos básicos, impostos pelas restrições legais como forma permanente de segregação aos moradores.

O que se apresenta em algumas imagens a seguir são os "territórios da escassez produzida" (ROBIRA, 2004 op. Cit.). As condições infraurbanas aqui visualizadas são, por outro lado, a forma através da qual penetra no imaginário dos moradores o acesso ao urbano, o desejo que remete à superação das condições precárias. São nesses interstícios que se qualificam os discursos sobre a "sustentabilidade social", como aqueles que enquadram os moradores no "risco social", na "vulnerabilidade". É também por essa escassez produzida que passam a operar as representações do espaço, pois que implicam os moradores na lógica da institucionalização pela via do acesso não somente à moradia "digna", mas às condições da "sustentabilidade social". 


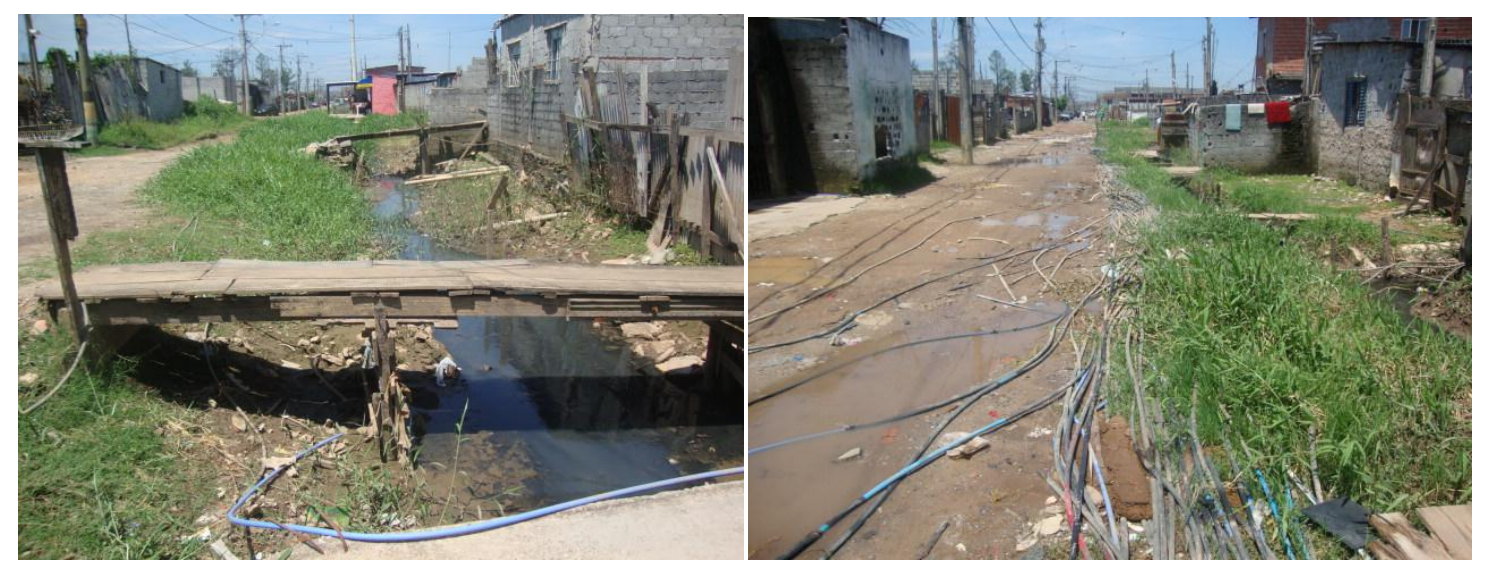

Algumas imagens do urbano desurbanizado do Pantanal. Para ter acesso a serviços básicos como água e luz, os moradores fazem ligações "irregulares" conhecidas por "gatos". É uma produção do espaço que se traduz não somente no privado, mas também no público, como a construção de "pinguelas" sobre a drenagem original e também aquela por eles realizada.
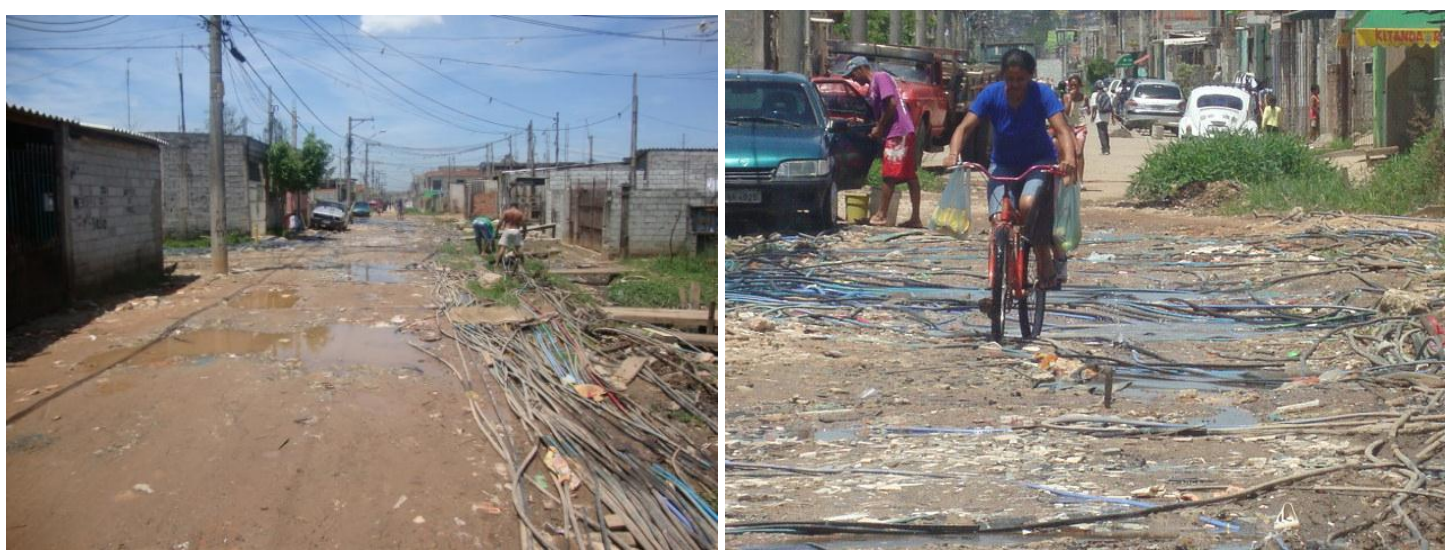

A maior parte das moradias é construída com alvenaria. Algumas apresentam mais de um pavimento. Outras ainda são totalmente construídas com materiais os mais variados, como placas, pedaços de madeira, lonas, etc.
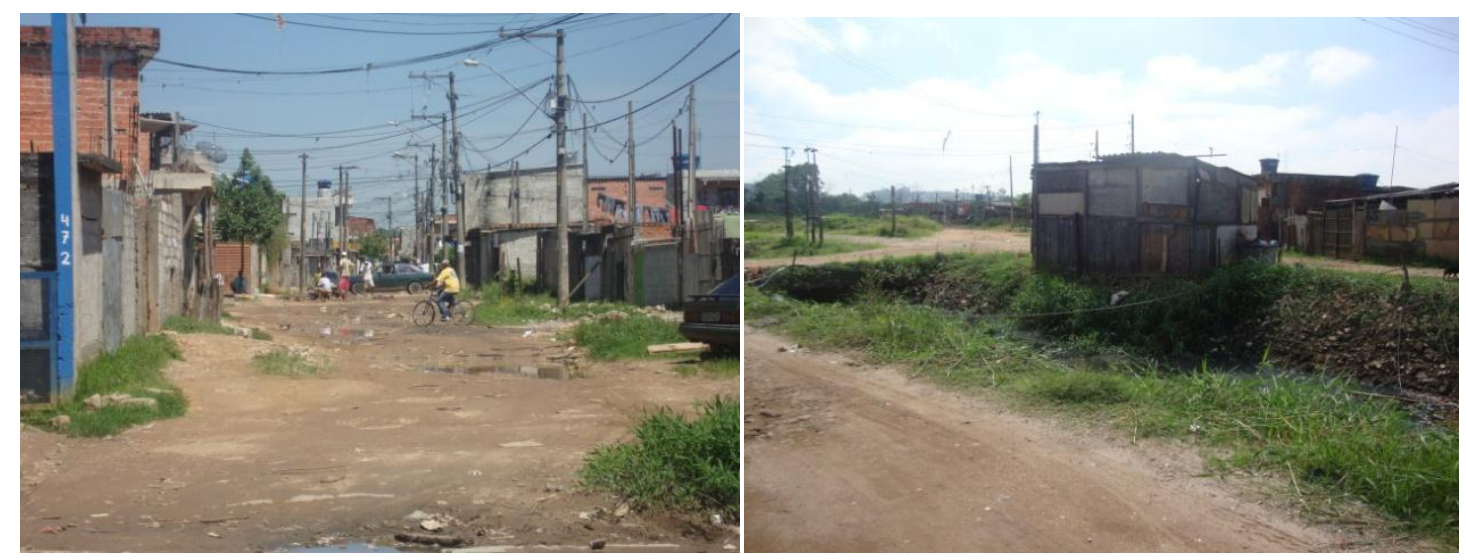
Por outro lado, tais condições infraurbanas derivam e são derivadas também da inserção dos moradores em formas de proletarização precária, baseada em serviços temporários, bicos, enfim, aquela sorte de atividades que Milton Santos (1994, op. Cit.) relacionou ao circuito inferior da economia e que permeiam a reprodução precária dessa população. Em pesquisa do IBGE, realizada no primeiro semestre de 2013, dos 10 bairros com menor renda em São Paulo, 3 estão no Pantanal da Zona Leste: Jd. Helena, Iguatemi, Jd. Paulista ${ }^{105}$. No site Agência Pública há uma vídeo-reportagem chamada Favela Fábrica ${ }^{106}$ feita no Pantanal. Mostra os trabalhos precários realizados por pessoas de diversas idades, incluindo crianças e adolescentes que costuram etiquetas em roupas, dobram sacolas que servirão de embalagens para lojas famosas dos shoppings de São Paulo, montam brinquedos, enfim, com poucas máquinas, em unidades montadas dentro de casa, jornadas extensivas e de baixa remuneração, essa população assume as formas de precarização e exploração extensiva da força de trabalho. No depoimento de um adolescente, de uns 12 ou 13 anos de idade, o trabalho de dobrar sacolas por longos períodos diários, em pé, é "distração para a cabeça", para não ficar "pensando nas drogas"... Mesmo posto como positivo nesta situação, podemos conclamar as proposições de Amélia Damiani, o trabalho como puramente negativo ${ }^{107}$. Aparece positivo nas palavras deste jovem porque confrontado com a própria condição de vida, o vivido como (des)interação espaço-tempo-lugar. Estamos diante, na verdade, de uma metrópole puramente negativa.

As restrições impostas pela legislação do Parque acabam, elas mesmas, por criar uma condição que podemos nomear infraurbana que torna-se parte constituinte do processo de expropriação como um todo. Diante do enfrentamento posto pela criação das áreas institucionais, este fator infraurbano torna-se discurso e poder ao mesmo tempo, pois o acesso a bens e serviços urbanos torna-se uma impossibilidade na medida em que "fere" os princípios estabelecidos pelo zoneamento, ao mesmo tempo em que se constitui como perpetuação desta situação precária e incorre numa

105 Reportagem postada pelo Site IG: ultimosegundo.ig.com.br/Brasil/SP/2013-08-11/vejaquais-são-os-dez-bairros-mais-pobres-de-as-paulo/HTML. Acesso em 13/08/13

${ }_{106}$ HTTP//apublica.org/2012/06/vídeo-favela-fabrica/ acesso em 09/2012

107 DAMIANI, 2000 p.28. 
impossibilidade imanente aos moradores, num abismo intransponível de acesso a estes bens.

O grande problema das áreas de ocupação precária dentro das várzeas se relaciona com as questões ambientais e sanitárias. Praticamente a totalidade das áreas de remoção são conformadas por invasões ou loteamentos não regularizáveis fato que dificulta ou mesmo impede a implantação de serviços públicos (SÃO PAULO, 2010BA p. 13)

Dessa forma:

Não existe cobertura adequada de esgotamento sanitário, coleta de lixo e abastecimento de água, fatores de degradação ambiental que torna as áreas insalubres e expõem a população a riscos sanitários. Essa situação é mais crítica no período de enchentes quando milhares de residências são invadidas pelas águas, muitas vezes poluídas e portadoras de vetores de enfermidades (Ibidem).

Para o caso do Pantanal o recrudescimento e a efetivação das operações de remoção se balizam por vários meios, mas a partir da condição particular da várzea, a inundação. Tornam-se mais objetivas, sobretudo nas inundações de grande monta. Nesses momentos são redigidos os destinos dessa população nos relatórios das instituições como se fossem seus próprios marcos históricos:

Em função das cheias excepcionais com ocorrência no período de verão, notadamente entre os meses de dezembro 2009 e fevereiro de 2010, estão sendo requeridas intervenções emergenciais visando a remoção e o reassentamento de populações residentes em áreas sob risco (SÃO PAULO, 2010B p. 16).

Uma nova onda de cheias corresponde a outra onda institucional para a remoção. A cada onda, o corpo institucional se refaz, transfigura-se a partir das formas de representação do espaço as quais se aproximam do desejo dos moradores em geral; cada vez mais imperiosas e apelativas pelas novas condições subjetivas socialmente aceitas, como é o caso da qualidade de vida, do ambientalismo, do acesso à moradia digna, da proteção social ao risco. Para este convencimento, agora é estratégico incorporar os próprios movimentos e suas lideranças locais no escopo da representação. A representação popular como representação do espaço, como estratégia de convencimento a partir da leitura "democrática" de um processo amparado por todos os setores sociais, inclusive os atingidos: 
A decisão de realizar o PVT foi amplamente divulgada através da imprensa e de varias reuniões realizadas com os representantes formais $e$ informais das comunidades envolvidas. As fortes enchentes que afetaram a RMSP no último período de chuvas (verão) proporcionaram maiores discussões sobre o PVT e aumentaram as reivindicações, por parte da população afetada e seus representantes, para sua imediata implantação execução. O PVT já foi discutido com duas instâncias consultivas: Comitê da Bacia Hidrográfica do Alto Tietê e o PVT (SÃO PAULO, 2010a p. 19).

Além das questões relativas aos territórios institucionais criados sob o cunho das legislações ambientais, habitar a várzea para os moradores do Jardim Pantanal implica em lógicas muito particulares em diferentes níveis ${ }^{108}$. São situações como a construção de aterros, comportas, barragens, andares superiores, tudo isso no próprio terreno da moradia.

Os moradores também se deparam com estruturas hidráulicas que influenciam diretamente na regulação do regime do rio Tietê a montante da Barragem da Penha, a mais influente nessa região pela sua condição de barrar as águas e mantê-las no Pantanal, uma forma sempre desdobrada, pois sua operação é determinada pelas possibilidades de regulação a jusante da barragem, onde se inicia a principal via do sistema de avenidas de fundo de vale, a Marginal Tietê. Por outro lado, os reservatórios nas cabeceiras do Tietê, Taiaçupeba, Biritiba-Mirim, Ponte Nova, Paraitinga e Jundiaí, também influenciam a vazão do rio diretamente nessa lógica desdobrada, pois podem inundar a área do Pantanal e, pela operação da barragem da Penha, preservar a Marginal Tietê.

Sobre a inundação ocorrida no verão 2009-2010, quando a região ficou alagada por quase dois meses, nossa hipótese é de que as estruturas hidráulicas a montante do Pantanal, as barragens de cabeceira do Tietê tiveram fundamental importância. Para esta análise é necessário pensar não somente no verão excepcional de 2009-2010, mas no inverno de 2009, no qual a atuação do sistema denominado La Niña produziu volumes de chuva muito acima das normais pluviométricas para o período:

O ano de 2009 teve uma acumulação anual de 1883,6mm, que é superior a média de 1933-2008 (1377,9mm). Nos meses de março, julho, setembro e novembro, a precipitação foi bem

\footnotetext{
${ }^{108}$ Sobre a particularidade que assume o cotidiano dos moradores das áreas de várzea na
} metrópole de São Paulo ver SILVA, 2009. 
maior que a média climatológica mensal. Sendo que o mês de julho teve uma acumulação de $200 \mathrm{~mm}$, enquanto a média climatológica é de $40 \mathrm{~mm}$. Em contrapartida, no ano de 2008 choveu apenas $0,4 \mathrm{~mm}$ em julho ${ }^{109}$.

Esses eventos em julho de 2009 foram de fato excepcionais, ou mesmo extremos, considerando as normais pluviométricas do período seco na região de São Paulo. Nossa hipótese é a de que os reservatórios de cabeceira citados acima e operados por concessionárias mantiveram esse volume pluviométrico das chuvas do inverno e da primavera de 2009 armazenado, até porque essa é a mercadoria que lhes permite a acumulação privada. O verão seguinte, também com eventos pluviométricos excepcionais, fez com que as concessionárias abrissem as comportas dos reservatórios por conta dos grandes volumes acumulados para o ano:

O trimestre de dezembro (2009), janeiro e fevereiro de 2010 (DJF), o verão, caracterizou-se por ter sido muito chuvoso ( $110 \%$ acima da média). O total acumulado neste trimestre foi de $1255,8 \mathrm{~mm}$, sendo mais chuvoso de toda série climatológica, que apresenta uma média de $609,7 \mathrm{~mm}$. Sendo assim, choveu mais do que o dobro do esperado para a estação. O mês de janeiro/2010 foi o mês mais chuvoso de toda a série histórica: $653,2 \mathrm{~mm}$ enquanto a média climatológica para este mês é de $222,4 \mathrm{~mm}^{110}$.

Com o volume das chuvas excepcionais do verão acrescidas àqueles também excepcionais já armazenados no inverno talvez acarretasse transbordamento do sistema de barragens. A solução foi "sangrar" estes reservatórios. Ao mesmo tempo, o volume de chuvas acrescido do excedente despejado pelos reservatórios faria o Tietê à jusante da Penha, ou seja, os trechos das Avenidas Marginais, transbordar para além do ocorrido na época. Diante desse fato, a decisão das operadoras foi fechar a barragem da Penha e impedir a passagem das águas de montante para jusante e assim preservar as Vias Marginais da interrupção por inundação ${ }^{111}$. Mesmo assim, ocorreram vários transbordamentos das Vias Marginais Tietê e Pinheiros. Por fim, as

109 BOLETIM CLIMATOLÓGICO TRIMESTRAL DA ESTAÇÃO METEOROLÓGICA DO IAG/USP - DJF 2009/2010 - VERÃO - p. 03 (grifos meus).

${ }^{110}$ lbidem.

${ }^{111}$ Em março de 2010 houve um debate na USP Leste do qual participou o Defensor Público Bruno Miragaia, que afirmou haverem sido fechadas neste período as comportas da barragem da Penha durante seis dias, conforme informações fornecidas pelo Departamento de Águas e Energia Elétrica (DAEE). Em conversa que tive com o líder comunitário Ronaldo Delfino, este confirmou que a barragem ficou fechada durante o período citado, fato que confirmou in loco, aumentando a linha da inundação no Pantanal. 
águas da inundação do Pantanal no verão 2009-10 correspondem não ao volume de chuvas daquele período (que certamente contribuiu), mas ao volume despejado pelas barragens de cabeceira aliados ao fechamento da Barragem da Penha, fato relatado em algumas reportagens, como a seguir:

17/12/2009 - 07h00

Comportas fechadas na barragem da Penha para proteger a marginal ajudaram a alagar a zona leste de SP

Fabiana Uchinaka

As seis comportas da barragem da Penha, na zona leste de São Paulo, foram completamente fechadas às 2h50 do dia 8 de dezembro, dia em que a cidade enfrentou fortes temporais e viu diversos pontos alagarem como há muito tempo não se via. Somente dois dias depois, às $17 \mathrm{~h} 20$, todas as comportas foram abertas. Os dados, fornecidos pelo engenheiro responsável pela barragem, João Sérgio, indicam que houve uma clara escolha da empresa responsável: alagar os bairros pobres da zona leste para evitar o alagamento das marginais e do Cebolão, conjunto de obras que fica no encontro dos rios Tietê e Pinheiros.

"Mesmo fechando as comportas, encheu o [córrego] Aricanduva. Se eu não tivesse fechado aqui, teria alagado as marginais e toda São Paulo", justificou Sérgio, que explicou que a decisão vem da direção da EMAE (Empresa Metropolitana de Águas e Energia), apesar de a barragem pertencer ao DAEE (Departamento de Águas e Energia Elétrica). Ele acrescentou ainda que no dia 9 duas comportas foram abertas às $10 \mathrm{~h} 10 \mathrm{e}$ mais duas às $21 \mathrm{~h}$.

$O$ engenheiro argumenta que cada barragem (são quatro em São Paulo: Móvel, Penha, Mogi das Cruzes, Ponte Nova) é responsável apenas por administrar o fluxo de água do local e não sabe o que acontece nos outros pontos, porque não há comunicação. Mas ele acredita que as comportas foram abertas nas barragens de cima, em Mogi, e isso influenciou no alagamento da região da zona leste. "Não recebo informações de outras barragens. As de cima são administradas pela Sabesp e as de baixo pela EMAE. Eu só respondo por essa barragem e às ordens da EMAE", disse. "Também acho estranho o nível da água não baixar aqui e não sei por que está indo para os bairros, mas não precisa ser especialista para ver que está assoreado [o rio]"112.

Os moradores têm consciência dessa operação. Em várias falas se revela a lógica da operação das barragens como fator da inundação na região.

Antes mesmo das chuvas o governo já fazia ações de alagamento. Uns três dias antes das cheias de dezembro, os córregos da região já estavam cheios, o que as pessoas não

${ }^{112}$ http://noticias.uol.com.br/cotidiano/2009/12/17/ult5772u6678.jhtm acesso 06/08/14 
entendiam, já que não chovia. Quando caiu a tempestade, ainda teve aquela ação do governo de abrir as comportas da Penha, que depois foram fechadas dia 7 e reabertas dia 10, às 7 horas. Foi isso que causou o primeiro alagamento", rememora. Vale lembrar que tal fechamento na Penha aliou-se à abertura das comportas da barragem de Mogi das Cruzes, em ponto mais alto do Tietê, de modo que a região alagada se transformasse inevitavelmente num piscinão, uma vez que se localiza no caminho entre as duas barragens. Difícil não enxergar orquestração de fatores (Ronaldo Delfino, à época membro do Conselho Gestor da APA Várzea do Tietê e líder comunitário, em depoimento para o Correio da Cidadania, 12 de fevereiro de 2010).

Em outro relato, a mesma relação entre a operação das barragens e a inundação:

\begin{abstract}
Alagados dois meses após o início das chuvas, desejavam que emergissem, ao menos, suas histórias e desejos. A causa principal da inundação, sustentavam, não eram os destemperos climáticos - mas a forma como foram manejadas seis das barragens do Alto Tietê. Atingidas pela cheia, ao menos 4 mil famílias sofriam pressões ilegais do governo do Estado para deixar suas casas, que eram derrubadas de imediato. Pomposamente apresentada como "o maior do mundo em seu gênero", o Parque Linear da Várzea do Tietê, obra que se pretendia construir na região, reforçava, ao invés de reverter, a segregação social e o divórcio com a natureza, que caracterizam as metrópoles brasileiras (Publicado na Seção outras palavras do Blog Terra livre conforme o link http://blogterralivre.wordpress.com/2010/04/27/\%e2\%80\%cperd eram-tudo-menos-a-vontade-de-lutar\%e2\%80\%9d/. Acesso 04/2012).
\end{abstract}

A própria leitura científica deste processo permite desvendar as relações de produção do espaço, uma vez que se realizam de acordo com as operações das estruturas técnicas e por elas se justificam, tal como aconteceu no caso da Light S/A na enchente de 1929, relatada no trabalho de Odette Seabra (1987, obra citada), cuja operação das barragens determinou o perímetro de apropriação privada das terras da várzea do rio Pinheiros pela Cia. LIGHT, assim como da expropriação das terras dos moradores por parte desta companhia, fato que se repete para o caso do Pantanal 80 anos depois, da mesma forma e com os mesmos requintes estratégicos:

Consistente com essa diretriz, o PVT (Parque Várzea do Tietê) se limita a remover as famílias que se encontram em situação de risco e ocupando áreas de preservação e conservação ambiental. A delimitação das áreas de intervenção para a implantação do parque linear foi determinada em função de estudos hidráulicos que definiram os limites das áreas 
inundadas de acordo com os parâmetros técnicos adotados pelo Programa (Tempo de Recorrência de 25 anos). Ainda se estudam a possibilidade de realizar algumas obras de contenção e drenagem que possam reduzir a extensão das enchentes e a necessidade de remoção (SÃO PAULO, 2010a p. 18).

Já diziam que "a tragédia se repete como farsa"113. Essa operação de barragens pode influir na área não somente como decisão política de manter o sistema de circulação viária das marginais, mas também como possibilidade de formular justificativas para a remoção dos moradores como forma de preservalos dos riscos da habitar uma área inundável (nunca é demais lembrar as famílias lá habitam há mais de trinta anos). Ou seja, são moradores que estruturaram seu cotidiano em meio a um espaço institucionalizado, sobre o qual incidem decisões políticas que determinam as relações socioespaciais, que obscurecem sua percepção ao invocar a tentativa de representar seus interesses. Aqui o cotidiano, a escala do indivíduo, da família, da vizinhança, o lugar como pertencimento e história se confronta com outra dimensão, do político, do poder, que a metrópole exprime como potência, do local ao mundial.

Tomemos emprestada a designação de Henri Lefebvre, o "ponto crítico" a respeito do momento histórico em que aquilo que se definia como cidade passa por uma metamorfose desencadeada por um processo de implosãoexplosão, o qual, para ser compreendido, necessita outra leitura no interior dos novos processos desencadeados (LEFEBVRE, 2004 p. 71-83). É dessa forma que o desvendamento das relações no Pantanal necessita também a compreensão dos diferentes agentes em diferentes escalas e processos que envolvem os conflitos ali estabelecidos. Tais condições pressupõem relacionar diferentes grupos que controlam não somente a mudança na legislação, a construção do Parque Várzea do Tietê, a remoção das famílias, mas também as empresas que manipulam o sistema hidrotécnico do Alto Tietê, que compreende as cinco barragens de cabeceira e a barragem da Penha, as quais permitem tanto o fluxo da vazão para montante como a retenção de toda a água do sistema para jusante.

\footnotetext{
${ }^{113}$ Karl MARX: O Dezoito Brumário de Louis Bonaparte. São Paulo: Centauro, 2008.
} 
Nesse ponto crítico se situa o conflito que defronta os moradores do Pantanal às instituições estatais e privadas, às formas contemporâneas de realização do capital que relacionam o espaço e a financeirização, os diferentes níveis e dimensões de uma economia política. Operam as instituições num território que configura objetivamente elementos da técnica e da engenharia para o controle dos processos naturais. Vivem os moradores tanto as condições do ambiente fluvial como as decisões políticas que procuram regular este ambiente. Por um lado, uma possível abordagem que permite a leitura simultânea desses muitos agentes no e pelo espaço remete à epistemologia da situação geográfica. Não se trata de um inventário, a tal ciência de síntese requerida por correntes positivistas, mas de uma condição simultânea que inclui a dimensão temporal do regime pluviométrico e da vazão do rio ao processo político que se desencadeia para a remoção dos moradores.

Nesses momentos de grandes inundações é que as formas de expropriação se recrudescem. O cotidiano se torna incerto no interior do jogo político. Os limites da área institucional não separam o que é edificado do que é permeável, o que é "sustentável" e o que não é, o que está no âmbito jurídico da "proteção" aos recursos naturais e o que está fora deste âmbito, "não protegido", sujeito à sorte das "mazelas" sociais. O limite separa o morador da moradia, das formas de sociabilidade, das condições destes estabelecerem uma relação espaço-tempo-lugar. Discurso e poder se instauram no cotidiano, nas perspectivas, no futuro, na incerteza. Povoa-se o imaginário do morador com um monstro a emergir das águas do rio, a qualquer momento, e pôr abaixo tijolo por tijolo, aquilo que a história cunhou e desenvolveu de diversas maneiras, o elementar, o direito, a propriedade, o obvio, o abrigo, o privado, o aconchego, as tantas e tantas definições deste que é o mais característico do humano, que Henri Lefebvre definiu como o habitar ${ }^{114}$. Tanto que, das estratégias de remoção é primordial: "Planificar a imediata desconstrução ou inutilização dos domicílios liberados para evitar risco de novas ocupações oportunistas" (SÃO PAULO, 2010BA p. 30). Tal estratégia vigora nas diversas

\footnotetext{
${ }^{114}$ Henri Lefebvre constrói a relação contraditória entre Habitar x Habitat a partir das formas de sociabilidade postas pela definição afetiva, pelos laços que resguardam o primordial momento do humano como construção de uma moradia contrapostos àqueles definidos pelas relações capitalistas, sobretudo as da propriedade privada como acesso à moradia. Ver LEFEBVRE, 2004 cap. IV.
} 
intervenções que ocorrem em São Paulo, tornaram-se uma prática para a qual implantou-se um termo cunhado nos meios institucionais como "desfazimento".

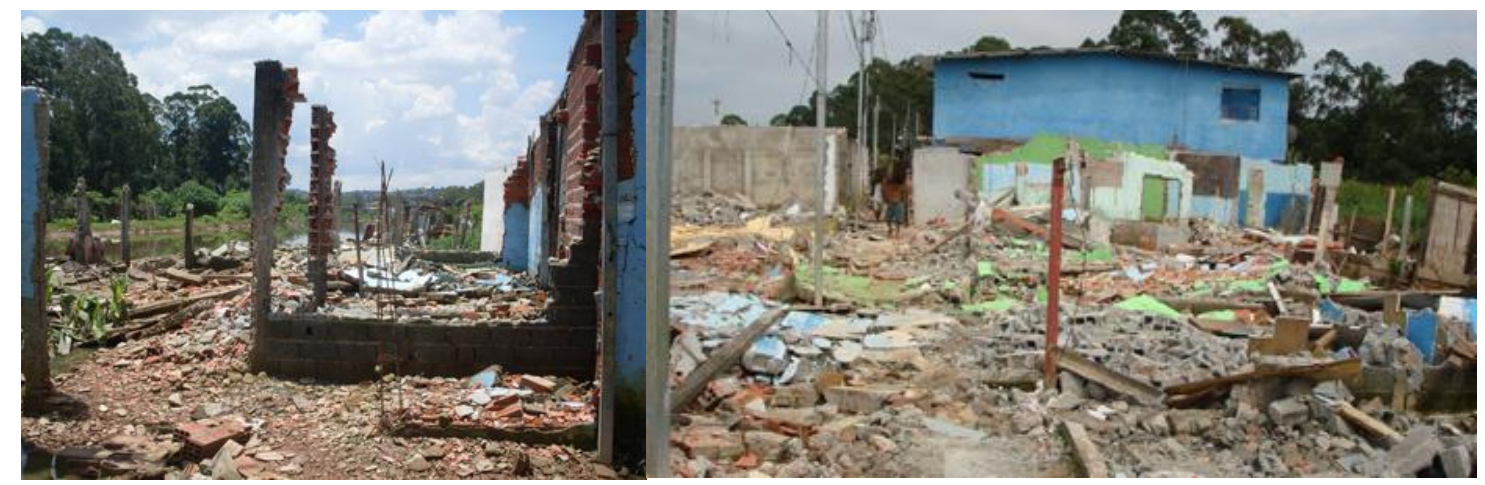

Uma das situações consideradas mais graves pelos moradores. As imagens da demolição das casas em meio às inundações do verão 2009/2010. Acima, fotos feitas na Viela dos Peixes por Ronaldo que pertenceu ao MULP (Movimento pela Urbanização e Legalização do Pantanal) e foi membro do Conselho Gestor. A foto da esquerda foi feita no dia 16 de janeiro, a da direita no dia 2 de fevereiro de 2010. Abaixo, as fotos também tiradas por Ronaldo em 23 de janeiro de 2010 mostram as casas sendo demolidas em meio à inundação. $O$ rio que aparece nas fotos é o Tietê.

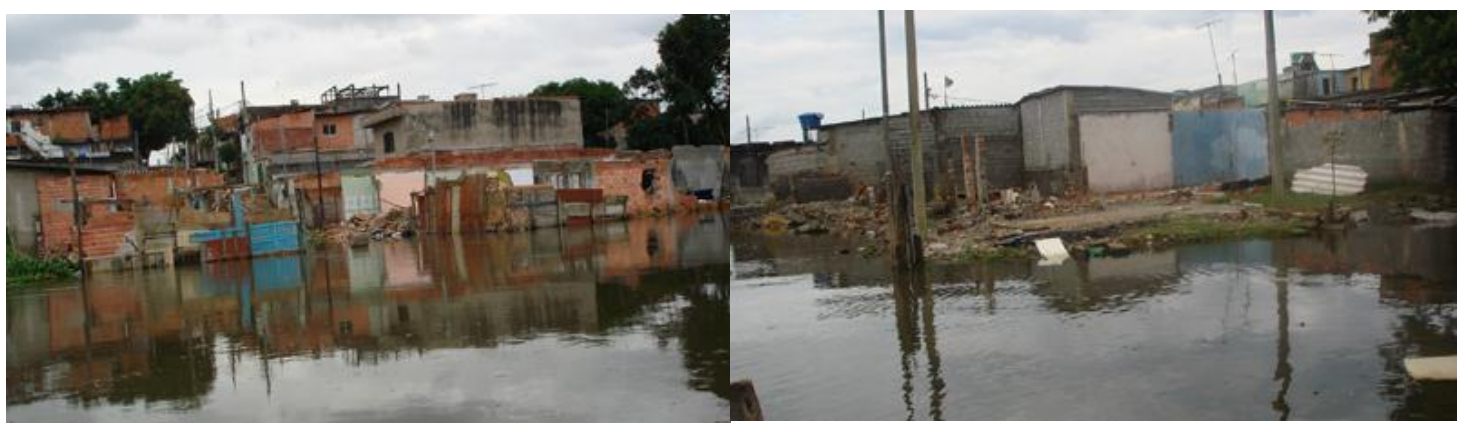

Disponível em : http://www.viomundo.com.br/arquivo/denuncias/ronaldo-do-pantanal-serra-ekassab-jogam-lixo-no-tiete/ _Acesso em 12 de 2012. 
A efetividade do discurso como possibilidade real se constitui num poder sobre o cotidiano dos moradores, poder este que se ramifica, em cuja rede formada repousam diversos outros poderes. A instituição, ela mesma não revelada, os próprios moradores que acatam a instituição, os que a querem negar, enfim, um emaranhado que os envolve e torna a insegurança exponencial. A fragilidade de sua luta em conjunto é o resultado. O monstro ganha forma no imaginário, do desfazimento, dos tratores chegando, da imponderabilidade, da remoção, da institucionalização da bolsa aluguel, são os tentáculos, uns poucos talvez para alguns, muitos para outros, um monstro que povoa o consciente e o inconsciente, o tempo dormido e o tempo acordado. Outrora, este ambiente dos rios sonolentos a divagar pelas planícies foram cunhadas por Aziz Ab'Saber de drenagem labiríntica. Para o caso dos moradores do Pantanal, hoje, labiríntica é a rede estruturada sob poderes que neste e por este território se sobrepõe.

As condições impostas para os moradores em remoção são as formas jurídicas vigentes nesta situação, a bolsa-aluguel e o cadastro para a aquisição de imóvel não quitado pela inserção nos programas habitacionais das secretarias de habitação municipal e estadual (SEHAB e CDHU respectivamente). Há relatos de populações removidas sem nenhum aparato de sustentação institucional. A Bolsa-Aluguel é o mecanismo a partir do qual a população recebe um auxilio para realocar-se, que corresponde a $R \$ 300,00$ mensais por seis meses e que pode ser renovado.

Também se trabalha com auxílio aluguel para custear as despesas de moradia enquanto se aguarda a disponibilização de uma solução habitacional definitiva ou mais adequada ao perfil socioeconômico da família em questão (SÃO PAULO, 2010a p. 19).

Algumas famílias que o receberam, conforme os relatos de alguns moradores como o de Zélia Maria, se dirigiram para áreas mais distantes, pois não era possível alugar um imóvel na região por esse preço. Conforme seu depoimento, depois das inundações de 2009/2010, diante das necessidades, ao menos temporárias, de realocação de algumas famílias, os aluguéis subiram na região, o que provocou o deslocamento de muitas para áreas mais distantes, como relatam alguns moradores e reportagens: 
[...] Mas, basta abrir a porta do apartamento 12 do condomínio para descobrir que as moradias oferecidas pelo governo estão longe de ser um bom exemplo de habitação adequada. $\mathrm{Na}$ unidade, de 42,6 metros quadrados, vivem 17 pessoas. São cinco crianças e um bebê recém-nascido, que dormem amontoados nos finos colchões doados pela prefeitura ainda na época das enchentes [...]. Pelos dados da prefeitura, atualmente 3.753 famílias estão recebendo o bolsa-aluguel, benefício de $R \$ 300$ oferecido durante seis meses àqueles que tiveram suas casas derrubadas. Destas, 340 foram levadas para os apartamentos da CDHU em Itaquaquecetuba. ${ }^{115}$

Conforme Zélia Maria, as formas de remoção e desfazimento acontecem de maneira obscura, pouco esclarecedora e no calor dos acontecimentos. A inundação das moradias pressionou muitos moradores a aceitarem a bolsaaluguel. Ao cadastrarem-se neste programa por não poderem ocupar suas casas inundadas por dois meses em certos casos, alguns moradores "automaticamente aceitavam" a remoção. Entre aspas porque ao serem cadastrados, automaticamente se comprometem a deixar a moradia. Nos relatos de Zélia, este fato não é esclarecido. Nas próximas horas virão as forças policiais para removê-los e por a casa abaixo. É o que aconteceu com a maioria dos moradores removidos, a casa é "marcada" com um X e posta abaixo.

O repertório político dessas ações torna-se, ao longo das inúmeras experiências na metrópole, uma tecnologia, um modus operandi cada vez mais incisivo e aparatado, uma construção biopolítica, pois que envolve o corpo naquilo que este expressa consciente e inconscientemente.

As reformulações políticas das formas de expropriação se recriam em função das novas condições objetivas, incluem-se as formas econômicas vigentes nos relações do Estado com a economia. Os planos preveem a contratação de empresas privadas para elaborarem o cadastro, além de outras tantas contratações em diversos campos de atuação, as chamadas terceirizadas para serviços variados: educação ambiental, serviços internos do futuro Parque, atividades de empreendedorismo, etc.

A UGP (Unidade de Gerenciamento do Programa [de Reassentamento]) será coordenada pelo DAEE, contará com a 
participação de representantes dos órgãos diretamente envolvidos na execução do PVT e com consultores externos, contratados para temas específicos. O trabalho de gerenciamento social que cuida da execução das atividades de campo será realizado através de empresas privadas contratadas (SÃO PAULO, 2010a p. 14).

Percebe-se uma lógica que enreda diversos setores por meio da remuneração financeira predisposta aos projetos não somente como obra propriamente dita, mas por diversos serviços elencados nos projetos e financiados pelas instituições. O quadro abaixo nos mostra diversos serviços remunerados a partir do financiamento os quais correspondem a um total de 14,65 milhões de reais para: "reabilitação e apoio social", "consulta e participação", "plano de comunicação social", "núcleo de atenção e reclamações", "monitoramento", "avaliação" e "gerenciamento social”; proposta do Plano Diretor de Reassentamento (São Paulo, 2010a p. 38).

Quadro 1

\begin{tabular}{|c|c|c|c|c|c|c|}
\hline \multicolumn{7}{|c|}{ Plano Diretor de Reassentamento/ Orgamento estimativo da primeira etapa em reais (R\$) } \\
\hline Item & Quantidade & Preço unitário & Total & BID & GESP & PMSP \\
\hline Soluções habitacionais/São Paulo & 7.500 & 60.000 & $450.000 .000,00$ & & 150.000 .000 & 300.000 .000 \\
\hline Soluções habitacionais/Guarulhos & 500 & 60.000 & $30.000 .000,00$ & 19.785 .600 & 10.214 .400 & \\
\hline Reabilitação e apoio social & 8.000 & 500 & 4.000 .000 & 250.000 & & 3.750 .000 \\
\hline Consulta e participação & 2 anos & 100.000 & 200.000 & 200.000 & & \\
\hline Plano de comunicação social & 5 anos & 100.000 & 500.000 & 500.000 & & \\
\hline Núcleo de atenção a reclamações & 5 anos & 100.000 & 500.000 & 500.000 & & \\
\hline Monitoramento & 5 anos & 200.000 & 1.000 .000 & 1.000 .000 & & \\
\hline Avaliação & 2 & 200.000 & 400.000 & 400.000 & & \\
\hline Gerenciamento Social (eq. Técnica) & Global & & 6.000 .000 & & 2.250 .000 & 3.750 .000 \\
\hline \multicolumn{3}{|l|}{ TOTAL } & $492600.000,00$ & $22.635 .600^{*}$ & 162.464 .400 & 307.500 .000 \\
\hline \multicolumn{3}{|l|}{ Participação (\%) } & $100 \%$ & $5 \%$ & $33 \%$ & $62 \%$ \\
\hline
\end{tabular}

(*) Componente reassentamento $=$ US\$13 milhões $x$ R\$1,7412 (PAF 2010 - 2012)

O orçamento geral para a construção do Parque também aponta diversas atividades orçadas relativas a serviços prestados a partir da contratação de empresas privadas, ou terceirização de serviços:

O objetivo geral da operação é a recuperação das várzeas da BAT e o propósito da implantação do PVT é conservar suas funções ecológicas, incluindo a redução de cheias. O Programa Várzeas do Tietê visa à recuperação, para efeito de amortecimento de ondas de

cheias, das várzeas remanescentes na bacia do Alto Tietê, a montante da Barragem da Penha, assim como, a atenuação dos efeitos de sua ocupação desordenada e dos consequentes problemas ambientais, urbanísticos e sociais, ensejando obter, de forma progressiva, a gestão integral de toda a várzea e melhor qualidade de vida para a população no entorno urbano da área de intervenção e, consequentemente da RMSP. Estes objetivos serão atingidos mediante a execução na $1^{\text {a }}$ Etapa do PVT de três componentes: 
i) Obras no valor de US\$154 milhões, que incluem movimentos de terra, obras estruturais (pontes, pequenos reservatórios de contenção de sedimentos, canais, proteção de taludes), implantação de núcleos/parques e via e ciclovia para circulação entre estas unidades, reflorestamento e recuperação de áreas degradadas;

ii) Reassentamento no valor de US $\$ 13$ milhões, com o objetivo de reassentar aproximadamente 500 famílias, no município de Guarulhos, vivendo em condições precárias em áreas de inundação. Este componente inclui os trabalhos de cadastramento das famílias e as ações de comunicação, consulta, divulgação, negociação de alternativas de reassentamento, construção ou compra de residências, acompanhamento e monitoramento das ações realizadas. As demais 7500 unidades habitacionais necessárias para o processo de reassentamento da $1^{\underline{a}}$ Etapa do PVT serão financiadas diretamente pelo Estado e pelo município de São Paulo;

iii) Sustentabilidade Ambiental e Social com investimento de US $\$ 17$ milhões, aplicados para apoiar as ações de fortalecimento das instituições envolvidas, educação ambiental para garantir a sustentabilidade das ações implantadas, preparação e implantação do Plano de Gestão do PVT, recomposição da cobertura vegetal das margens do rio e estudo de novas unidades de conservação no interior da APA VRT, em conformidade com o Sistema Nacional de Unidades de Conservação (SNUC).

Além dos três componentes acima o Programa contempla um componente gerencial (iv) composto pelas ações de Suporte Técnico e Gerenciamento (US\$16 milhões), que incluem o desenvolvimento de estudos e projetos específicos, a contratação da empresa de gerenciamento, atividades de supervisão e apoio ao Programa (São Paulo, 2010a pp18-9).

\section{A empresa DIAGONAL ${ }^{116}$ foi contratada para o cadastramento dos} moradores para formar o banco de dados do reassentamento. Tal situação implicou os moradores numa predisposição velada das moradias a serem demolidas. São várias as queixas em relação à forma como tal cadastramento aconteceu, principalmente com relação ao esclarecimento no que diz respeito à

\footnotetext{
116 DIAGONAL: Transformação de Territórios é uma empresa de Gestão Social que realiza diversos trabalhos para empresas variadas, tanto públicas como privadas, nacionais e internacionais, segundo site da empresa, em mais de vinte países. Neste site podemos visualizar uma variedade de projetos desenvolvidos no Brasil, todos eles de cunho "sócioambiental-territorial". Conforme os dizeres da própria empresa: "É também acreditar que o território - matriz da vida social, econômica e política - é gerador de sentido tanto individual quanto coletivo. Unir estas duas variáveis - pessoas e territórios - é a nossa busca. Desde o início percebemos que uma análise profunda do território e todas as suas variáveis eram a base para qualquer estratégia". Disponível em http://www.diagonal.net/Conteudo.aspx/Conteudo?idForm=bcb1ee31-becd-48cf-b985d8256c8f45f9\&idSub=00000000-0000-0000-0000-000000000000\&idConteudo $=00000000$ 0000-0000-0000-000000000000. Acesso em 10/2014.
} 
demolição da moradia. Ao se cadastrarem para o programa bolsa-aluguel por não terem condições de ocupar sua moradia em função da inundação, "aceitavam" sem que lhes fosse esclarecido, a demolição de suas moradias.

No Plano Diretor de Reassentamento (São Paulo, 2010a) consta a construção de uma Unidade de Gerenciamento (UG) responsável, entre outras coisas, pelas informações aos moradores (inclusive orçada conforme consta no Quadro 1 deste capítulo). Ninguém com quem eu tenha falado sabe sobre tal unidade. Em vários fóruns de discussão foi ressaltada a ausência do DAEE para esclarecimentos da população. Numa reunião da qual participei, os presentes tiraram a proposta de redigir um documento baseado na então recém-sancionada Lei da Transparência para solicitar ao DAEE as informações mais básicas sobre o Parque. Ainda em 2013, muitos moradores, mesmo lideranças, não sabem exatamente os limites das remoções:

Porque hoje eles não apresentam aquela delimitação, que é a delimitação de onde elas (as famílias) vão ficar e de onde elas vão sair, e para onde elas vão, se vão ser indenizadas, eu acho que não é justo a gente ficar 25 anos numa área que nem o Jardim Helena, morando lá, e nos ter de sairmos da nossa moradia, perder tudo e começar tudo de novo ${ }^{117}$.

$\mathrm{Na}$ verdade, esse é um dos pontos importantes que compõem as estratégias, a desinformação, a inacessibilidade aos órgãos definidores do processo, enfim, elementos da trama labiríntica que dispõe os moradores na incerteza. É comum nas reuniões e fóruns essa incerteza reinante, relativa ao perímetro do Parque, às remoções, ao acesso às novas moradias. As próprias instâncias do Poder Público que lutam em defesa dos direitos dos moradores têm dificuldade de acesso ou mesmo nenhuma informação a respeito do que se passava no Pantanal:

Trinta e cinco dias depois da primeira enchente, a Defensoria Pública continuava cobrando explicações da Secretaria de Infraestrutura Urbana e da Subprefeitura de São Miguel Paulista sobre o que estava sendo feito para garantir a vida e a saúde dos moradores dos bairros alagados. Sem respostas, o órgão entrou na Justiça com uma ação civil pública para obrigar a Prefeitura e o DAEE a realizar os serviços necessários e para que a Sabesp preste informações e entregue documentos sobre providências adotadas para drenagem da água retida (A partir do UOL Notícias, Disponível

\footnotetext{
117 Fala do líder comunitário Pedro Guedes - http://www.ptalesp.org.br/noticia/p/?id=5682\#.UIwWeNdWSo, acesso 06/08/14; reportagem 13/10/13.
} 
em $\quad$ http://blogterralivre.wordpress.com/2010/01/27/mp-edefensoria-de-sp-investigam-alagamentos-na-zona-lestemesmo-com-acao-judicial-pouco-foi-feito/. Acesso 04/2012).

Nas falas dos moradores são muitos os questionamentos sobre quando serão removidos, quem será removido, qual o perímetro de remoções, etc. Outra coisa muito presente são as formas de remoção até então estabelecidas, pela truculência das derrubadas das moradias, pela condição em que vivem os moradores removidos assistidos pelo programa bolsa-aluguel, os quais tiveram que se dirigir para áreas mais distantes pelo valor insuficiente para um aluguel na região, ou se estabeleceram em casa de parentes. Outros foram para unidades habitacionais ainda inacabadas ou insuficientes para o total de população removido, também para áreas mais distantes, como foi o caso de várias famílias removidas para Itaquaquecetuba ${ }^{118}$.

Outro momento das incertezas é o "congelamento", ou seja, a situação na qual os moradores são impedidos de construir benfeitorias, ampliar suas moradias, enfim, o medo de um trabalho que será perdido, de um esforço e um emprego de dinheiro que serão considerados ilegais nos termos da lei, ou mesmo "inúteis" uma vez que a moradia será demolida e esse dinheiro não ressarcido pela impossibilidade de indenizações prevista na lei. No 4ํㅜㄴóm do Pantanal com a presença dos Defensores Públicos do Estado de São Paulo que trabalham com as questões urbanas, alguns moradores levantaram essa situação, como foi o caso relatado de um morador que queria construir mais um cômodo e que foi aconselhado a não fazê-lo, pelas circunstâncias do congelamento. Há relatos de moradores que foram alertados pelas forças de vigilância, como é o caso da Operação Defesa das Águas (ver Anexo 1), de que as benfeitorias construídas seriam demolidas por força da lei.

Essa Operação conveniada entre várias instâncias do Estado age como força repressora dos processos de ocupação e mesmo de ampliação da moradia. Até a entrada de material de construção na área é considerada ilegal pelos agentes dessa operação. Os discursos institucionais os colocam, ao

\footnotetext{
${ }^{118}$ Nas intervenções dos moradores no $3^{\circ}$ Fórum do Pantanal, uma das falas da moradora Dona Ana revela que muitos moradores removidos para o conjunto habitacional de Itaquaquecetuba retornaram ao Pantanal dadas as precárias condições em que se encontravam naquela área. Segundo informação do representante da Secretaria, foram disponibilizadas neste conjunto 340 unidades habitacionais. Conforme o relato de Zélia Maria, a quantidade de unidades era insuficiente em relação ao total de famílias removidas e o conjunto habitacional ainda não estava pronto.
} 
contrário dos relatos dos moradores, em consonância com as ações dos próprios moradores:

A PMSP desde 2008, no marco da Operação Defesa das Águas, vem atuando fortemente no controle das ocupações nas áreas de proteção de mananciais do município e em áreas de interesse ambiental (Várzea do rio Tietê) na zona Leste da cidade. Essa operação se iniciou com a instalação de uma unidade da Guarda Municipal no local que juntamente com as ações da Secretaria do Verde, Polícia Militar e Civil, Subprefeitura e comunidade têm conseguido êxitos no controle das invasões, anteriormente bastante frequentes na região (SÃO PAULO, 2010a p.41) ${ }^{119}$.

Todo este aparato institucional alinhava os elementos jurídicos e executivos aos outros processos constitutivos da produção do espaço no Pantanal, processos estes de caráter coercitivo, de práticas que se repetem historicamente como o chamado "desfazimento", muito presente em outros tantos casos de remoção de moradores na metrópole de São Paulo, como já referenciado nos trabalhos, por exemplo, de Mariana Fix e Ana Fani Alexandre Carlos $^{120}$, tornou-se prática política amparada juridicamente em diversos processos de remoção.

Mas é importante salientar que novas estruturas sociais, subjetivadas nas "vontades" e "necessidades" comuns a todos os cidadãos, se põem agora como direitos elementares, como suporte da própria condição de vida na sua condição de "qualidade de vida". Tanto para as populações a serem removidas como as que permanecerem nas imediações do Parque, da mesma forma como um consenso da população em geral, se estabelece uma "carência" de estruturas de lazer, de espaços verdes, revelados nas estatísticas da quantidade de verde por habitante, cifra que tais projetos pretendem, no plano das aparências, diminuir. O "verde" torna-se média social, equivalência dos processos socioespaciais, justificativa apaziguadora das mazelas sociais, do redentor contato com a "natureza", no âmbito das formas contemporâneas dos espaços de representação. As novas estratégias de produção do espaço se inserem neste momento:

A área de intervenção, com extensão total de $75 \mathrm{~km}$ passará a caracterizar-se como um grande parque linear, respeitadas as

\footnotetext{
119 Ver FOLHETO ANEXO 1 Operação Defesa das Águas: folheto distribuído na comunidade, inclusive nas escolas, que criminaliza moradores das áreas de várzea.

${ }^{120}$ Conforme FIX, 2001; CARLOS, 2001.
} 
restrições do zoneamento e do plano de manejo da APA VRT, criando uma diversificada infra-estrutura de núcleos de uso público, com destaque para a oferta de estacionamento, áreas verdes e boas condições de acesso, além da variedade dos equipamentos de lazer, cultura e esportes, beneficiando grande parcela da população da RMSP (SÃO PAULO, 2010a p. 19).

Como nos lembra LEFEBVRE (2008), dentro das condições intrínsecas da reestruturação das relações sociais de produção, o que este autor denomina neocapitalismo, as novas condições para a produção do espaço se situam, sobretudo, nas estruturas do tempo-livre, extensão do tempo de trabalho como consumo do tempo, como tempo de consumo dentro da ordem socioespacial contemporânea. Tal conformação se relaciona às formulações do mesmo autor sobre a "sociedade burocrática de consumo dirigido" (LEFEBVRE, 1991). Os pressupostos das renovações urbanas das últimas décadas em São Paulo trouxeram à tona tais empreendimentos ${ }^{121}$, destinados às formas de uso do tempo. Dessa maneira, as estruturas do tempo-livre e as "carências" de espaços verdes se coadunam nas formas de representação do espaço como mecanismos de dominação política dentro das novas estratégias de produção do espaço embasadas nas médias sociais.

No 3ํFórum do Pantanal realizado em 15 de junho de 2012 houve a participação da Secretaria Municipal de Habitação fazendo a sua exposição sobre o andamento das obras de construção dos conjuntos habitacionais destinados à população que será removida. Segundo as palavras do representante desta secretaria, "ninguém será removido sem que haja uma moradia para reassentá-lo" (embora vários moradores já tivessem sido removidos sob o recurso do programa bolsa-aluguel e a própria apresentação mostrava a insuficiência de moradias diante da população desalojada).

De certa maneira, a remoção sob tal condição, de reassentamento, se ajusta, embora não seja um consenso, a algumas expectativas de moradores diante da impossibilidade de permanecerem no local, de receberem outra moradia em troca. A forma como esse processo será realizado é o grande questionamento da população, uma vez que é visível a insuficiência das moradias construídas, assim como a questão de lançar os moradores numa

\footnotetext{
121 Veja-se o trabalho de Otilia Arantes (in ARANTES, VAINER, MARICATO, 2000) Uma estratégia Fatal (PP 11-74); sobre a renovação urbana no centro de São Paulo definida nos termos da produção de espaços destinados ao consumo da cultura.
} 
dívida imobiliária, uma vez que esses projetos de moradia popular predispõem aos reassentados moradias não quitadas. Isso faz parte do pacote jurídico que não prevê indenização por benfeitorias, ou seja, as moradias construídas, uma vez que se trata de área pública, sem a propriedade privada juridicamente estabelecida, além da sempre referida nos relatórios institucionais "invasão" por parte dos moradores. Uma das bandeiras levantadas por alguns representantes de movimentos de luta é "uma casa por outra". Conforme alguns discursos que pude colher, na impossibilidade da permanência, alguns moradores se mobilizam para conseguir a remoção para outra casa. Numa entrevista dada ao jornal local Correio da Cidadania, edição de 29 de abril de 2010, Marzeni Pereira, integrante do Movimento Terra Livre, faz vários relatos a respeito das expectativas dos moradores relacionadas às ações dos poderes institucionais, entre elas a questão da aquisição de nova moradia pela perda da anterior:

[...] A prefeitura não pode forçar a derrubada das casas. Nós achamos que o governo tem o direito de projetar um parque desses, mas antes deve dar uma destinação correta às famílias que moram lá. Já derrubaram 3000 casas, sem conceder o bolsa-aluguel e novas moradias na mesma proporção. Sendo assim, o primeiro ponto é o fim imediato das ações de derrubada. O segundo é o fim do terrorismo e do desrespeito aos direitos humanos dos moradores em ações nas áreas inundadas. Eles chegam lá sem qualquer mandado judicial dizendo para as pessoas que vão derrubar as casas e derrubam mesmo. Ass vezes a pessoa sai de casa e, quando volta do trabalho, a casa está no chão. Em outros casos, a pessoa volta pra casa e seus móveis estão colocados na frente de outra casa. Exigimos também a construção sem custos de moradias para abrigar as famílias atingidas. Ou seja, trocar a casa da qual a pessoa foi removida por outra. Isso porque a prefeitura fala que vai construir novos apartamentos para as pessoas afetadas, mas irá vendê-los ao invés de concedê-los em troca da casa derrubada. E as famílias que já tinham sua casa querem outra em troca sem ter de comprar nada. $O$ terreno da Vila Curuçá, declarado zona de interesse social e local onde a prefeitura pretendia construir apartamentos para essas famílias, é um desses casos em que a prefeitura quer vender as casas para as pessoas, que ainda ficariam sem indenização $\quad[\ldots]$ (Disponível em http://blogterralivre.wordpress.com/2010/04/29/alagados-dazona-leste-de-sp-lutam-contra-remocoes-e-exigem-novasmoradias/. Acesso 04/2012). 
Percebe-se que o processo de remoção é feito de forma violenta e que não condiz com os apontamentos dos poderes instituídos representados neste fórum. Em outro depoimento, desta vez colhido neste fórum, a moradora do Jardim Romano Mariana faz diversos relatos que envolvem a luta dos moradores pelo acesso ao urbano, a condição de deixar o local somente pelo acesso a outra moradia e lembra que o trabalho objetivado na construção da moradia atual se define na justiça da aquisição de outra moradia sem custo:

Eu sou moradora do Jardim Romano, passei este $2010 \mathrm{com}$ a enchente, é muito pavoroso, você constrói a sua casa, você deixa de comer um pão para por um tijolo em cima do outro, para chegar a prefeitura e os nossos governantes lá em cima, porque somos pobres, que se fossemos ricos esses homens não faziam o que fizeram. Eu passei por provas difíceis lá no Jardim Romano, morreu foi muita gente, muita gente foi para os predinhos lá em Itaquaquecetuba e estão voltando porque não aguenta. Nós os moradores, nós podemos lutar, nós não temos armas, nós somos o povo, eles são só poucos governantes que podem fazer alguma coisa. Tenho minha casa, foi marcada, passou máquina, estourou o esgoto, eles chegaram a dizer para mim que meu esgoto não era pago e eu disse que ia à SABESP para eles indenizarem os vinte e dois anos que eu moro aqui. Não tem água, não tem luz, então o que eu estou pagando aqui é em vão? Nós somos moradores de uma caixinha de fósforo, nós pagamos imposto, nós temos o direito, e os nossos deveres também, então se eles querem as áreas nós podemos abrir mão sim, mas que deem uma casa digna sem ficar pagando uma coisa que nós já tiramos do bolso. Lutamos e somos moradores, nós aqui já tivemos tudo, vem a depressão, vem a morte, quantos pais de família já morreram porque deixaram os nossos governantes fazer uma coisa indevida dessas? Nós temos áreas invadidas e grandes, a [impossível entender], a Bauduco, áreas de várzea que tem hotel, os apartamentos da Caixa (Econômica Federal). [...] Luta! Vocês são os moradores, eu já saí com polícia muitas vezes. Fica! Bate o pé! A nossa proposta lá no Jardim Romano foi "uma casa pela outra".

A incerteza não se desfaz, assim como a insatisfação pela inserção num novo processo de moradia a partir da aquisição por dívida, isso para uma parcela a qual, pelo que notamos, não corresponde sequer à metade das remoções. Diante das explicações do representante da Secretaria de Habitação, o qual expôs por meio de um PowerPoint os números das remoções 
(da estimativa inicial de 5000 para o número atual de 7000$)^{122}$, assim como do andamento das construções de unidades habitacionais de conjuntos habitacionais (130 unidades previstas para dezembro de 2011 e 750 previstas para agosto de $2012^{123}$ ), das possíveis áreas de construção dos conjuntos que faltam para suprir a demanda, da quantidade de famílias vivendo com o bolsaaluguel (2350 famílias segundo ele, mais de 3000 conforme os moradores ). Os números não conferem com os do Plano Diretor de Reassentamento enviado ao BID pelo Governo do Estado de São Paulo, conforme os quadros abaixo:

Quadro 2 - Terrenos Selecionados pelo CDHU

\begin{tabular}{|c|c|c|l|}
\hline Município & Localização & Estimativa de UH's & \multicolumn{1}{|c|}{ Situação } \\
\hline \multicolumn{4}{|c|}{} \\
\hline Arujá & Arujá C & 700 & Propriedade da CDHU \\
\hline Itaquequacetuba & Sede & 1000 & Propriedade da CDHU \\
\hline \multirow{3}{*}{ Guarulhos } & Vila Aimoré & 190 & Com decreto de Interesse Social \\
\cline { 2 - 4 } & Sacramento & 60 & Laudo de avaliação concluído \\
\hline \multirow{3}{*}{ São Paulo } & S. Miguel Paulista & 280 & Laudo de avaliação concluído \\
\cline { 2 - 4 } & Lageado & 540 & Com decreto de Interesse Social \\
\hline Total & & 2710 & \\
\hline
\end{tabular}

Fonte: São Paulo, 2010a p. 42.

Quadro 3 - Terrenos Selecionados pela SEHAB

\begin{tabular}{|c|c|c|c|c|}
\hline Terenos/Emp. & Localização & Area $(\mathrm{m} 2)$ & Estimativa de UH's & Dist. Do PVT \\
\hline Cangaíba I & Penha & 8.143 & 219 & $640 \mathrm{~m}$ \\
\hline Cangaíba II & Penha & 9.784 & 228 & $600 \mathrm{~m}$ \\
\hline Cidade Lider I/II & Itaquera & 26.432 & 570 & $8,9 \mathrm{~km}$ \\
\hline Vila Curuçá & Itaim Paulista & 9.567 & 228 & $2,9 \mathrm{~km}$ \\
\hline Lageado 1 & Guainases & 24.423 & 380 & $5 \mathrm{~km}$ \\
\hline Lageado II & Guainases & 38.805 & 975 & $4,8 \mathrm{~km}$ \\
\hline Lageado III & Guainases & 27.715 & 475 & $4,6 \mathrm{~km}$ \\
\hline Lageado IV & Guainases & 6.390 & 190 & $4,7 \mathrm{~km}$ \\
\hline \multicolumn{2}{|l|}{ Total } & 151.259 & 3265 & \\
\hline
\end{tabular}

Fonte: São Paulo, 2010a p.41.

Mas, em tempos de fragmentação, o espaço torna-se o bem primordial e disposto às novas condições de reprodução. Além do Pantanal em si, o representante da Secretaria de Habitação apresentou outros projetos cujos perímetros também se situam na região e integram em parte a várzea do Tietê, como é o caso do Projeto Renova São Paulo, do perímetro Água Vermelha, $122 \mathrm{O}$ total de remoções disposto nos relatórios enviados ao BID pelo GESP é de 8000 , sendo 7500 em São Paulo e 500 em Guarulhos para a primeira etapa da execução do Projeto.

${ }^{123}$ Estávamos em 2012. 
onde se situa a Favela da Paz, em cuja fala do representante, será removida, sem nenhuma outra explicação.

Me chamou a atenção um significativo momento deste 3ํㅜórum, no qual estavam presentes representantes da Secretaria de Habitação e do escritório de arquitetura LIBESKINDLLOVET Arquitetos S/S Ltda., "vencedor" do projeto exposto em licitação para o Plano de Ação Integrada "Água Vermelha 2 - lote 17", perímetro da região incluída nas intervenções propostas pelo "Renova São Paulo"124. Após ouvir muitas críticas a respeito das incertezas da população e dos desmandos dos Poderes Públicos, a arquiteta do escritório contratado se manifestou da seguinte maneira:

"[...] estamos levantando onde tem escolas, quais as áreas carentes,[...] para poder ter um entendimento como um todo[...] eu não moro aqui, eu não conheço[...] depois do diagnóstico[...] saber quais são as carências, as necessidades[...] Somos profissionais da área, temos conhecimentos que vocês não têm[...] eu até entendo que ninguém quer sair de sua casa para ir morar num apartamento[...] Eu gostaria de fazer uma pergunta a vocês: vocês não gostariam de ter praças, ciclovias, escolas, equipamentos públicos, piscinas, bibliotecas, qualidade de vida?[...] O único jeito é pegar as áreas mais carentes, abrir espaços nessas áreas[...] Não há espaço para construir esses equipamentos"125.

Gostaria de ter talentos de artista para revelar o que foi este momento, por alguns instantes mesmo as almas mais inflamadas se aquietaram por fora e se inquietaram por dentro, numa espécie de silêncio resultante da própria impossibilidade de que o murmúrio que os inquietou pudesse se sobrepor.

\footnotetext{
${ }^{124}$ Diário Oficial do Município 09/03/2012 - 2011-0-270.200-1/INT.:HABI-G/contrato: 021/2011SEHAB/CONTRATADA LIBESKINDLLOVET ARQUITETOS S/S LTDA/ Desp.: À vista do que consta neste processo administrativo, e das manifestações técnicas de acolho, AUTORIZO a adoção de cronograma financeiro de $\mathrm{fl}(\mathrm{s}) 169$ referente ao contrato 21/2011 - SEHAB, firmado com a Empresa LIBESKINDLLOVET ARQUITETOS S/S LTDA, para a "Elaboração de plano urbanístico, estudo preliminar, projeto básico e executivo de urbanização e edificações para 0 Plano de Ação Integrada - AGUA VERMELHA 2 - LOTE 17". Em consequência e com fundamento nos Decretos no 52.934/2012 DETERMINO: I. A emissão de Nota de Reserva e Empenho de Recursos referentes ao primeiro quadrimestre/2012, no valor de $R \$ 913.307,24$ sendo $R \$ 879.279,14$ para pagamento de serviços e $R \$ 34.028,10$ para o pagamento do reajuste, de acordo com a PLANILHA DE EMPENHO - 2012 de $\mathrm{fl}(\mathrm{s})$ ํㅜ 170, em nome da empresa LIBESKINDLLOVET ARQUITETOS S/S LTDA inscrita no CNPJ/MF no 59.86.270/0001-15 onerando a dotação $n^{\circ}$ 8 86.10.16.451.1131.1.277.4.90.51.00.03 URBANIZAÇÃO DE FAVELAS.

${ }^{125}$ A gravação desta reunião está muito ruim, muita gente, conversas, crianças, além do sotaque, lembrando que o escritório é espanhol, enfim, selecionei trechos que considero importantes para se ter uma ideia das proposições gerais da arquiteta do escritório responsável, cujo nome também não consegui entender.
} 
Salvo o barulho das crianças, indiferentes às discussões, levadas ao fórum por alguma impossibilidade das mães de mantê-los em outro espaço, ninguém se manifestou. Manifestaram-se sim, ouvia-se o murmúrio quase concordando com a frase exposta, alguns "sim" penetraram o silêncio, como se uma brisa sibilasse a imensa vontade de todo aquele urbano ausente que a fala da arquiteta revelava como possibilidade.

É esse silêncio que soa como a captura do desejo. É nesse momento sutil no qual calam os fervores é podemos, ao menos, pressupor a lógica das representações no preenchimento dos interstícios sociais como espaços de representação. O concebido, anunciado como o acesso ao urbano reverbera no vivido, assume sua concretude no silêncio da consciência dentro da qual se embatem $o$ imaginário povoado pela ausência proposital $e$ as formas insinuadas do urbano.

Alguns instantes depois, mesmo antes do fim do discurso da arquiteta, o silêncio se quebra na fala de Zélia Maria ${ }^{126}$, que em termos gerais expõe que os moradores querem sim todos esses objetos citados pela arquiteta: "nós queremos tudo o que você falou, nós não somos contra o Parque [..]”. Em linhas gerais, Zélia expôs que pôr fim às mazelas das inundações, a ausência de equipamentos urbanos, são sim desejos da população, mas compreende um processo político de grande amplitude territorial ao relacionar, por exemplo, tal contexto das obras à realização da Copa do Mundo de 2014, como obras que integram um conjunto; que outras formas de uso são permitidas na várzea do rio. Citou vários exemplos, como o Centro de Treinamento do Corinthians; falou também da remoção dos moradores em 2010 para os "apertamentos" de Itaquequecetuba, de maneira não só irônica, mas com uma leitura de perda, de uma situação na qual sabe-se que a remoção para outras áreas é inevitável, mas que a luta, a crítica, o questionamento não cessam.

Nos diz Amélia Damiani: "Não é a ausência do urbano que lhes maltrata, é o insinuar de sua presença" (DAMIANI, 1993 p.213), aquela que toca fundo nos desejos manifestos de uma pobreza que não se mede pela equivalência em dinheiro. Claro está que os planejadores, o mercado imobiliário, os que

\footnotetext{
${ }^{126}$ Pelos mesmos motivos da fala anterior e com o agravante de que Zélia estava sem microfone, ficou impossível relatar sua fala na íntegra. Associei a gravação às anotações que havia feito no dia e exponho neste trecho uma ideia geral.
} 
movimentam os interesses do capital no espaço sabem bem do que se trata e se referenciam por meio dos pressupostos socialmente estabelecidos que conformam as representações do espaço, as médias sociais, o acesso à cidadania pelos direitos constituídos àqueles indivíduos ainda "desajustados" das condições contemporâneas da metrópole, para os quais a promessa de uma maneira "sustentável" de viver começa pela perda, pela remoção, se consubstancia na expropriação, tanto que vem resguardada com as palavras institucionalização, desfazimento, dívida imobiliária, tudo aquilo que enquadra os moradores nos moldes da racionalidade da reprodução contemporânea:

Considerar o reassentamento como uma oportunidade de desenvolvimento sustentável. A intenção é a de aproveitar os efeitos da inserção social que gera o acesso a condições adequadas de moradia e aos serviços essenciais, para promover uma situação que possibilite o desenvolvimento das comunidades envolvidas.

As políticas habitacionais do GESP e da PMSP trabalham com a ideia de que moradia digna é um conceito de cidadania que passa pelo direito à propriedade, pela urbanização e a promoção do desenvolvimento social. Essa visão coloca as ações sociais, principalmente as de pósocupação, no mesmo nível de importância das obras das unidades habitacionais, o que significa contar com recursos humanos e materiais para desenvolver programas de organização comunitária e de desenvolvimento pessoal e profissional (SÃO PAULO, 2010a p. 19).

Ao refletir sobre o urbano como ausência permanente, apresenta-se 0 desejo dessa população empobrecida do acesso às estruturas físicas que se situam no espaço, que lhes é não somente distante, mas principalmente alheia. Veja-se o impacto causado pela fala da representante do escritório responsável pelo perímetro "Água Vermelha" nos presentes ao fórum. A vida nos mínimos, representada pela moradia precária, pelo entorno precário, pelos serviços precários, pela vida precária enfim, revela-se desejosa e excluída de outras estruturas, como são os equipamentos de lazer, estes que virão com a construção do Parque Várzea do Tietê, com as intervenções do Projeto Renova São Paulo.

O espaço das representações tornado representação do espaço. Estes projetos, do Parque Várzea do Tietê, do Renova São Paulo, dos Parques Lineares, assim como tantos outros, insinuam o acesso aos serviços, ao lazer, às condições urbanas que distinguem os diferentes lugares da metrópole, 
assim como os seus moradores. Portanto, opera no desejo, este que é, de modo implícito, produzido pela condição em si da fragmentação urbana a partir de sua produção desigual. O "acesso" ao urbano insinuado nesses projetos opera no vivido dos moradores. Dessa maneira, se estabelece uma conexão entre o concebido e o vivido. Os termos da alienação são postos pela formulação proposital do desejo em meio à ausência vivida como infraurbano. As representações do espaço postas pela sua produção desigual, relativamente ao cotidiano espoliado, são instrumentais nessa lógica, pois criam a consciência do desigual e, ao mesmo tempo, o desejo. Essa tênue linha invisível e, ao mesmo tempo, concreta, é o fundamento do espaço de representação.

Neste momento a problemática do Pantanal da Zona Leste se amplia para inúmeras áreas da metrópole de São Paulo para as quais estão previstas as remoções de população cujas cifras se aproximam 100 mil pessoas ${ }^{127}$. São inúmeros projetos pautados em legislações próprias instituídas ao longo dos últimos 20 anos e, sobretudo, as recentes, que referenciam diversas condições de intervenção no espaço (ver Anexo IV - Mapa das Remoções).

Em todas essas intervenções há um fator em comum, a remoção dos moradores. A justificativa para tal efetivação se dá, sobretudo, pela razão da inexistência jurídica da propriedade privada (exceção de algumas áreas, inclusive com propriedades de alto preço no mercado imobiliário, como é o caso da Operação Urbana Água Espraiada para a construção de um parque linear ao longo da Avenida Jornalista Roberto Marinho), ou seja, loteamentos considerados irregulares e outras ocupações, principalmente as favelas.

Para o caso do Pantanal, diversos são os momentos tanto nos relatórios como nos relatos em que a não-propriedade é ressaltada como algo a ser extirpado, e que a partir dos investimentos, volta a reinar a legalidade, a moradia como regular.

Essa particularidade é que em mais de $90 \%$ dos casos, trata-se da remoção de bolsões de ocupação irregulares, carentes de infraestrutura básica e constantemente afetados por enchentes o que caracteriza um ambiente degradado com precárias

\footnotetext{
127 Conforme artigo publicado no site Carta Maior (acesso 05/2013): http://www.cartamaior.com.br/templates/materiaMostrar.cfm?materia id=21019
} 
condições sanitárias e de habitabilidade. Outro fato importante é que essa população há tempo vem reivindicando junto ao Poder público, soluções habitacionais para remover as famílias em situação de risco e obras de contenção para preservar as áreas mais consolidadas (SÃO PAULO, 2010a p. 04).

Nossa leitura é de que a permanência dos pobres como processo intrínseco da formação da metrópole estabelece condições lógicas nas formas de expropriação baseadas, como nos expõe Amélia Damiani (1993), num cotidiano assegurado, na forma do acesso à moradia a partir dos programas institucionais. Assegurado está também o espaço como condição para o capital, uma vez que a pobreza dessa população é paga com a pobreza da habitação institucional. Nestes termos a moradia assegurada (para alguns) se une intimamente às necessidades do capital. A não-propriedade é resultado do processo e não sua negação. É alçada à condição de propriedade como resposta lógica ao espaço como produto do capital, do qual somente se pode desfrutar a partir da constituição da propriedade:

Apesar de não estar prevista nenhum tipo de solução sem custo, normalmente as unidades habitacionais são vendidas a preços subsidiados e compatíveis com a renda de cada família atendida, a política habitacional do Estado e Município, permite estabelecer mecanismos de acesso à moradia sem custo ou a custo simbólico, porém sem transferência da propriedade do imóvel (Instrumento da concessão de uso) (idem p. 19).

A aquisição da moradia não quitada como proposição na qual as estruturas físicas resolveriam o cotidiano espoliado, do acesso não somente à propriedade, mas também aos benefícios da urbanização, revela o urbano como perda, ausência, formas insinuadas no acesso às infraestruturas, mas que não resolvem, ao contrário, afastam a condição do urbano como fruição e põem a propriedade privada e suas derivações como propósitos elementares da própria fruição:

O programa também proporcionará benefícios indiretos aos proprietários de imóveis e de estabelecimentos comerciais e de serviços localizados no entorno, na medida em que os investimentos proporcionarão aumento significativo na movimentação de recursos, prestação de serviços e valorização imobiliária, ao mesmo tempo em que atrairá maior número de frequentadores à região. Por outro lado, serão criadas no interior da área de intervenção, oportunidades de pequenos negócios, com geração de emprego e renda, na medida em que serão necessários serviços de permissionários 
diversos em atividades comuns aos parques urbanos (SÃO PAULO, 2010b p. 20).

É significativo o conflito que se estabelece, pois os moradores sabem dessa condição para a qual estão sendo empurrados. Lutam, se organizam, acabam até por se inserir neste processo pelas formas que os poderes instituídos definem sua inserção, como é o caso de Oswaldo, morador que tornou-se representante da comunidade no Conselho Gestor do Parque, substituiu Ronaldo Delfino, representante anterior. Ambos envolvidos de maneira diferente na luta para assegurar os direitos, mas estes somente na forma jurídica reconhecida, o que define a própria luta dos moradores como representação no interior da ordem institucionalizada-institucionalizante.

\begin{abstract}
Não tomamos aqui a escassez numa qualidade explicativa da história e menos ainda numa teoria econômica, mas a tomamos como um dado explicativo das atitudes (LEFEBVRE, 1991 p.29).

O estudo da vida cotidiana oferece um ponto de encontro para as ciências parcelares e alguma coisa a mais. Mostra o lugar dos conflitos entre o racional e o irracional na nossa sociedade e na nossa época [...] Ela visa a virar pelo avesso esse mundo em que os determinismos e opressões passam por racionais, ao passo que a razão sempre teve como sentido e fim o domínio dos determinismos [...] A atitude que valoriza as opressões contém de fato uma ideologia disfarçada de racionalidade e de ciência [...] Ao cotidiano, conjunto do insignificante, responde e corresponde o moderno, conjunto dos signos pelos quais essa sociedade se significa, se justifica, e que faz parte de sua ideologia (Idem, p. 30).
\end{abstract}

As forças políticas se definiram por diversos meios, a ciência, a técnica, a jurisprudência, a força policial, tudo isso se contrapõe à permanência dos moradores em suas moradias originais, aquelas pelas quais o muito trabalho da autoconstrução é de significativa relevância e que no contexto atual significa perda. O reconhecimento dessa perda se traduz num momento também significativo na minha leitura. Em uma reunião com lideranças e interessados nos assuntos da remoção foi tirada a proposta de uma grande divulgação para o próximo encontro, pois a participação popular massiva é fundamental nessa articulação para reivindicar junto ao Poder Público. Uma das ideias que os presentes abraçaram foi a adoção de um slogan que seria bandeira para apresentar a problemática aos moradores: "minha casa, minha dívida". A alusão ao programa de aquisição de moradias populares no qual os moradores 
se inserem os coloca, conforme sua leitura, numa condição não de cidadãos, mas de consumidores que novamente se dispõem, como a própria história de sua mobilidade na metrópole, à busca pela moradia definitivamente nos termos da mercantilização, ponto de chegada, o titulo de propriedade. Talvez uma leitura semelhante à de Henri Lefebvre que nos remete à propriedade como miséria traduzida naquilo este define como relação contraditória "habitarhabitat":

Uma nova miséria se estende, que toca principalmente o proletariado sem poupar outras camadas e classes sociais: a miséria do habitat, a miséria do habitante submetido a uma quotidianeidade organizada (na e pela sociedade burocrática de consumo dirigido) (LEFEBVRE, 2004 p. 142).

Dessa forma e por este caminho dirigido pela modernização da sociedade estruturada pelas condições da reprodução das formas sociais organizadas em torno de uma racionalidade posta pelas categorias fundamentais do capital é que uma multidão empobrecida por esta mesma razão instrumental é condicionada (esta designação é proposital) a aceitar pela via institucional a sua nova inserção na sociedade "burocrática de consumo dirigido". Não podemos perder de vista que, para o caso do Pantanal, essa via foi possível pela existência de uma forma política, o rio Tietê. Sim, natural e política. Natural porque suas particularidades, ambiente fluvial, ali estão manifestadas numa ordem cósmica que não deixará de sê-lo. Política, pois definida por uma ordenação territorial pressuposta no interior das definições postas pela relação capital-espaço na metrópole de São Paulo como metamorfoses imprescindíveis no movimento contemporâneo crise-acumulação capitalista.

Essa é a forma velada da violência que a expropriação expõe, está nos documentos como subtítulo, está subscrito no discurso das instituições. É a presença-ausência como momento da análise, da apreensão, a metalinguagem, mas a "ocultação necessária não pode ser absoluta e o conhecimento põe fim a ela” (LEFEBVRE, 2004 p. 56). É por esse obscurecimento que se impõe a produção do espaço como coisa conclamada socialmente, necessidade que se põe por meio das formulações da política média. É ideológica e prática ao mesmo tempo, sua violência aparece como o "reino da finalidade racional": 
Uma vez que a regra é o desenraizamento generalizado e as separações, um mal-estar geral acompanha a satisfação vinda da ideologia, do consumo, do predomínio do racional. Tudo torna-se calculável e previsível, quantificável e determinável. Tudo deve integrar-se numa ordem (aparente e fictícia) fortalecida pelas coações (Idem, p. 42-3).

Para o caso do Pantanal, da construção do Parque Várzea do Tietê, há uma lógica que o ambientalismo como pressuposto dispôs enquanto forma social, ou, ao contrário, que as formas sociais dispuseram o ambientalismo como lógica pressuposta. De uma maneira ou de outra, torna-se essa prática ambiental condicionante no momento atual para os financiamentos, sobretudo de agências internacionais, como é o caso do Banco Interamericano de Desenvolvimento que financia parte da construção do Parque Várzea do Tietê. A lógica ambiental se constitui como fundamento para a realização da lógica capital-espaço. Não se trata de simples expropriação, mas que torna-se necessário revesti-la de condições outras que perpassem as representações sociais, como são as do ambientalismo, das condições sustentáveis da moradia e da reprodução social. Dessa forma, a violência da expropriação é velada, realiza-se como necessidade social de todos na busca por condições sustentáveis que devem se tornar desejo e dever de todo e cada cidadão, do Estado e das entidades políticas, sociais e financeiras, como as agências de financiamento. Se apresenta a lógica das práticas sociais postas pela representação da natureza. Mais do que isso, as práticas sociais postas pela relação "verde por habitante" passam a representar as aspirações sociais do encontro, do gesto, da espontaneidade. O Parque Várzea do Tietê carrega tais representações e se assume como conteúdo disposto à fruição social.

Teoricamente, a natureza distancia-se, mas os signos da natureza e do natural se multiplicam, substituindo e suplantando a "natureza" real. Tais signos são produzidos e vendidos em massa [...] Todos os "significantes flutuantes" que a retórica utiliza se agarram à sua re-presentação para encontrar um sentido e um conteúdo (ilusórios). O que não tem mais sentido procura reencontrar um sentido pela mediação do fetiche "natureza" [...] Quanto aos "espaços verdes", última palavra das boas intenções e das deploráveis representações urbanísticas, o que pensar senão que constituem um substituto medíocre da natureza, um degradado simulacro do espaço livre, aquele dos encontros, dos jogos, dos parques, dos jardins, das praças? O espaço assim neutralizado numa degradante democratização [...] (LEFEBVRE, 2004 p. 36). 
Mas, vão mais além da pura ilusão. Como menciona acima Lefebvre, espaços neutralizados (o destaque é meu). Por cima da história se põe a representação como esquecimento da luta por moradia, até mesmo do cotidiano. A representação trata disso por muitas formas. Apresenta-se à sociedade em como signo que povoa o desejo pelo urbano, o racional, o desenho, o que thes foi sempre ausente como moradores. As imagens, como as que seguem abaixo, o plano, estendido sobre o papel, se refaz no imaginário e converte a burocracia estatista em ordem social: "conduz a projetos que perecem claros e corretos porque são projeções visuais sobre 0 papel e sobreo o plano de um espaço desde o início postiço" (LEFEBVRE, 2008 p. 22).

Criar camadas que se sobrepõem à práxis, como se fossem sedimentos geológicos que as escavações históricas pudessem revelar. São práticas que atravessam o tempo e ressignificam a dominação social. Como nos fala Guy Debord:

A necessidade capitalista satisfeita pelo urbanismo, como glaciação visível da vida, pode se expressar - segundo a terminologia hegeliana - como predominância absoluta da "pacífica coexistência do espaço" sobre o "inquieto devir na sucessão do tempo" (DEBORD, 1997, p. 113).

De certa maneira, o urbano desejado se insinua nos planos, povoados de imagens, como foram as apresentações (PowerPoint) das instituições nos fóruns do Pantanal. Se erguem as formas insinuadas sobre os escombros do vivido. Não se trata somente das demolições, da vida cotidiana e suas derivações, do insignificante como constructo da consciência e ao mesmo tempo social, estes que vem abaixo com os tratores. Povoar a própria consciência com significados exteriores, vindos da lógica que opera a varredura objetiva e subjetiva, essa é a preocupante insinuação dos espaços de representação.

As imagens difundidas pelos órgãos responsáveis pela construção do Parque, como as que estão abaixo, produzidas e divulgadas pelas instituições propugnam cenários idílicos nos quais se combinam a natureza e a sociedade num urbanismo "quase natural" de tão sustentável. 


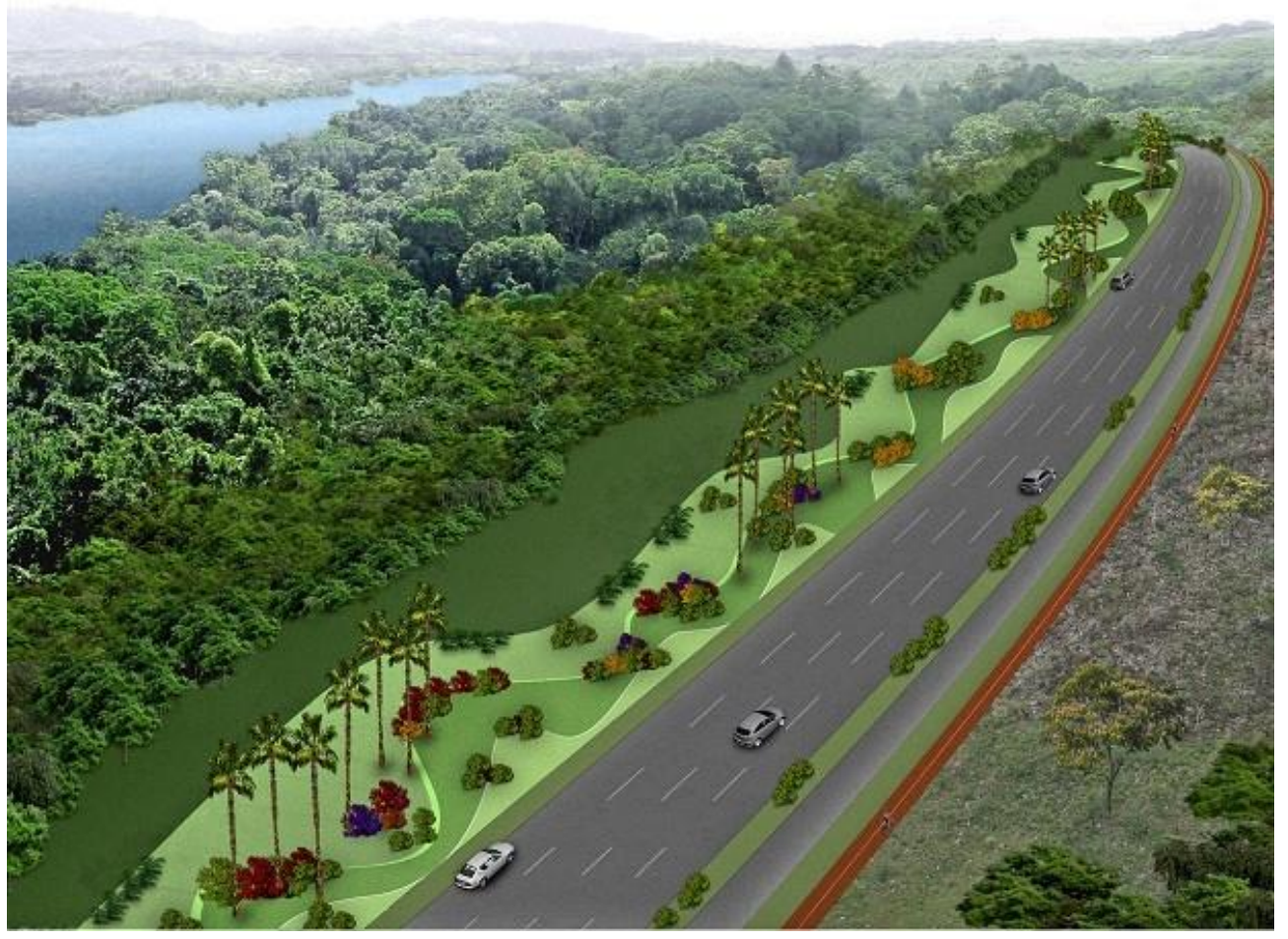

http://g1.globo.com/sao-paulo/noticia/2013/08/rio-tiete-tera-23-km-de-ciclovia-entre-penhae-itaquaquecetuba.html acesso 06/08/14

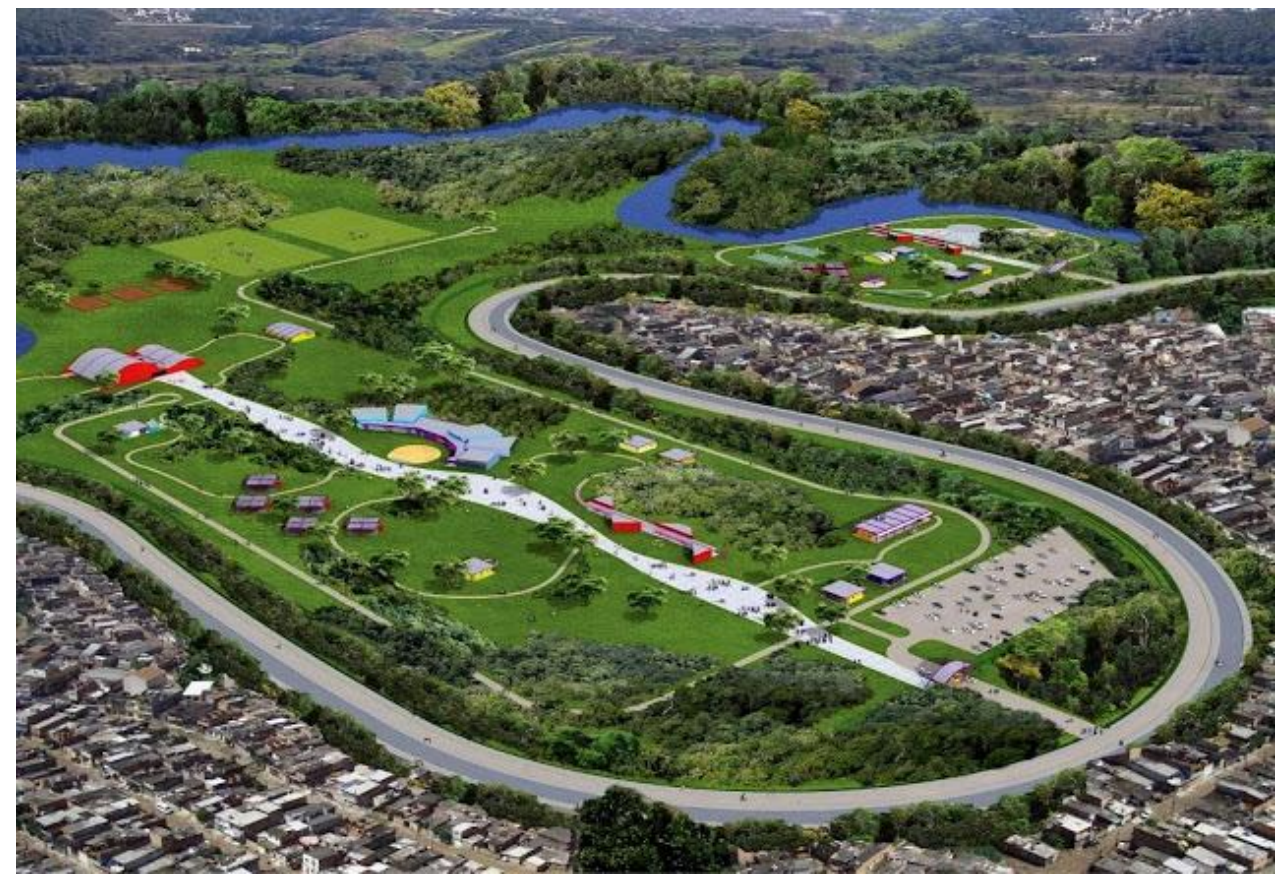

http://www.daee.sp.gov.br/index.php?option=com content\&view=article\&id=565:parquevarzeas-do-tiete-o-maior-parque-linear-do-mundo\&catid=48: noticias\&ltemid $=53$ acesso $06 / 08 / 14$ 
Da mesma maneira que outrora, como foi em fins do século XIX e primeiras décadas do $\mathrm{XX}$, em que a lógica da relação capital-espaço se apresentava num conjunto ideológico e prático que sustentava as formas de segregação, por exemplo, com as políticas higienistas, no nosso tempo, também se apresentam essas necessidades, postas ainda por outras formas tão veladas. São os casos das entidades que simulam a vontade social, que perpetuam o desejo social por condições igualitárias, paritárias, de se encontrar uma média nas relações sociais, uma forma que pressupõe a todos um ganho, a média social, a política média como nos fala Marcio Rufino da Silva ${ }^{128}$. São exemplos contemporâneos destas formas os fóruns representativos, como os conselhos gestores, ou mesmo as audiências públicas para a apreciação dos projetos políticos. Ainda que os planos para a existência de tais entidades fossem bem intencionados, o que não é o caso para a área do Pantanal, pois vários desses fóruns apresentados nos projetos e documentos das entidades tanto públicas como privadas nunca saíram do papel ${ }^{129}$, a verdadeira questão aqui é a da representação posta como condição de obscurecer o conflito de classe que se interpõe às novas condições da reprodução.

A expropriação como avesso da posse, mas integrada na forma propriedade. Não é possível habitar no Pantanal, essa ordem é posta pela propriedade. A sua forma resguarda tanto o institucional, o que foi decretado, como o ilegal, o que não existe perante o reino da racionalidade. Das duas maneiras o Estado integra o espaço pela desintegração imposta aos moradores. A estes resta integrar-se, pois, na promessa da expropriação está a

\footnotetext{
${ }^{128}$ Há tempos reverbera na sociedade contemporânea que determinados índices, tais como verde por habitante, moradia por habitante, saúde, educação, enfim, servem de patamar para projetar aquilo que se convencionou chamar "qualidade de vida", esta mesma como uma representação da média social. As médias mascaram as formas de apropriação, ou mesmo de acesso a bens e serviços urbanos, contabilizando e definindo o cidadão médio, ou seja, aquele que frui e desfruta dos significados sociais contemporâneos acima descritos. São os fundamentos da vida organizada, da urbanidade como razão funcional. Não somente uma diferenciação social se esconde por trás desses índices, mas que estes tornaram-se referência na busca social, precisam ser alcançados por meio de intervenções as mais variadas no espaço urbano e servem, por isso mesmo, às práticas e ideologias do planejamento. Sobre a política média, ver o trabalho Marcio Rufino da SILVA: A Reprodução Urbana nas Tramas da Metrópole: A Operação Urbana Consorciada Vila Sônia. Tese de Doutorado. São Paulo: Universidade de São Paulo, 2013.

${ }_{129}$ O projeto apresentado pelo Governo do Estado de São Paulo prevê a construção de uma Unidade Local de Gerenciamento responsável pelo esclarecimento dos moradores, suas queixas, detalhes sobre o projeto, enfim, uma exigência do BID para a execução de projetos desse tipo. Tal unidade nunca existiu.
} 
forma propriedade como finalista, a oportunidade oferecida pelas instituições aos moradores, ou melhor, a menor parte deles, de tornarem-se proprietários.

Para a outra parte, cuja expropriação pura e simples, sem nenhum destino, é fim último, como aconteceu em outros momentos no Pantanal, resta a mobilidade na metrópole, a busca por moradia. O mesmo processo aconteceu em 1996, quando as inundações daquele verão possibilitaram as ações de remoção dos moradores. Sem a consolidação da Área de Proteção Ambiental (APA, à época era esta a categoria), os moradores retornaram ao lugar. Todas as ações de 2009/2010 resultaram em algo parecido, pois o Parque não se consolida e os moradores retornam. Na visita em 01 de junho de 2014, lá estavam novamente assentando suas moradias nos lugares de onde foram expulsos. Os restos da metrópole, tábuas, placas, algumas alvenarias, tudo se põe novamente. $O$ mesmo vale para as instituições. $O$ Parque é um compromisso com os credores, pois as liberações dos financiamentos permanecem (ver Anexo 3). Estava previsto para o município de São Paulo em setembro de 2014 o início das obras de dois núcleos, Jardim Helena e Itaim-Biacica, os quais deveriam ser concluídos em novembro de 2016. De qualquer modo, a lógica imperativa da acumulação do espaço mantém tudo em suspenso, como se levitasse nas ondas de cheia do Tietê.

Habitar-habitat é em si uma contradição vivida por todos. No Pantanal, nos parece que a luta dos moradores é pelo reconhecimento daquilo que foi construído, não como matéria objetiva, mas como substância do vivido, embora em conflito, reconhecido e aceito com tal. Parece-nos imperar nessa lógica somente aquilo que é puramente negativo. 
Conclusão 
A metrópole é um fenômeno inconcluso. Suas metamorfoses recorrem a sua própria criação, rasgam na própria carne. Nesses tempos, o que parecia estável de repente se transforma. A mística do urbano como esperança, de multidões atrás da realização da vida melhor, como à procura de um objeto mágico, tal qual nos fez pensar Mario de Andrade $^{130}$, o muiraquitã, que traria sorte e felicidade aos que o possuíssem. A negatividade oculta nessa busca se enevoava na conquista aparente do que era perseguido, o trabalho, a moradia. Vistos assim, a olhos nus, apaziguavam o sofrimento e faziam calar a miséria diante do esforço dispendido nas longas jornadas da cotidianidade urbana. É como se todos pudessem tocar o muiraquitã, pouco que fosse.

Como na estória, o muiraquitã é uma propriedade privada, do Gigante Venceslau. Para além da sorte de ter 0 amuleto, seus poderes permitiam tragar as forças em torno de si, acumula-las, expandi-las. Viver dessa fome incomensurável tornou-se uma força aterradora que o próprio Venceslau não controlava. Sujeito e sujeitados caminham confrontados por esse poder. Não é assim que termina a estória, mas nos serve de adendo, pois que a nossa permanece aparente e oculta ao mesmo tempo, posta e disposta pela negatividade.

Não há urbano para todos talvez seja o nosso trágico fim, na metrópole antitética, não há permanências, tudo se rompe, se descontinua, e a história flui por essa negatividade, se refaz em outra de sua própria substância.

Seu corpo quase inteiro revela-se a partir de uma perspectiva, produto de uma divisão do trabalho anterior, como espaços da reprodução da força de trabalho. Agora, lançada numa outra lógica, se aproxima daquilo que anteriormente se constituía como sua ausência, física mesmo, de se materializar para além do infraurbano, o urbano como forma. Mas, nessa e por essa condição como resultado interno da metropolização, se constitui na formação simultânea da propriedade e, no interior desta, não como seu oposto, mas como impossibilidade mesmo, a não-propriedade.

Posta como mercadoria, a propriedade é negada como acesso para significativas parcelas da população empobrecida, o que resulta numa metrópole fragmentada pela lógica que constitui o legal e o ilegal, o regular e o

${ }^{130}$ Mario de ANDRADE: Macunaíma, o Herói sem nenhum caráter. Belo Horizonte: Itatiaia, 1985 
irregular. Diante de tais condições, a forma fictícia que representa a riqueza e o poder põe-se a mover sob novas relações ao requerer daqueles que à metrópole construíram, seus próprios espaços, suas moradias. É o formato recente da metropolização, a acumulação de espaço no interior da produção desigual deste. É esta, creio eu, a face contemporânea da reprodução que aqui se apresenta. Digo aqui, pois, o capital, ou seja, as relações sociais de produção sempre se reproduziam por simultaneidade, a própria condição do espaço fragmentado e desigual.

Na São Paulo do século XXI parece ser esta a realidade. Uma metrópole profundamente fragmentada e, ao mesmo tempo, homogênea pela força da reprodução. A condição antitética que esta assume diante de tal processo se revela na luta pelo espaço que se recrudesce nas últimas décadas. Claro que esta luta sempre se fez presente, mas penso ser este intenso conflito pelo espaço nas décadas recentes um dos sinais deste processo. As inúmeras reintegrações de posse de terras há muito ocupadas em diversas áreas da metrópole são sinais do interesse por essas novas condições para a remuneração de capitais pela via do espaço. Por outro lado, há um recrudescimento dos movimentos de luta por moradia, estes também em diversas áreas, na forma de ocupações de terrenos e edifícios há muito "congelados" no aguardo oportunidades de remuneração.

A fragmentação predispõe por diversos mecanismos vastas áreas da metrópole à expropriação, mesmo e apesar de estarem ocupados por moradia há várias décadas. É o caso não só do Pantanal, mas de boa parte da metrópole paulistana. Por essa lógica, o espaço se dispõe aos negócios financeiros, torna-se contrapartida de financiamentos privados e estatais, sobretudo para este último. Às estruturas produtivas anteriores, assumem o lugar novas estruturas não necessariamente improdutivas, mas que revelam novas formas de uso do tempo, o tempo livre como tempo de consumo, para o consumo do tempo. Áreas de lazer, turismo e, para o nosso caso, os Parques, com seus atributos e apelos ambientais, mas que servem ao capital financeiro pela via do financiamento a esses projetos territoriais que se tornam dívida pública para garantir a remuneração financeira.

No entanto, concretizar essa lógica não é simples expropriação, mas garantir a "aceitação social" de um processo tido como "necessário" tanto aos 
que são expropriados como aqueles indiretamente "beneficiados". São as representações do espaço como processos que obscurecem a face da relação capital-espaço em meio à expropriação. O fazem sob os conteúdos objetivos e subjetivos os quais tornam a leitura das contradições sociais algo que passa puramente pela necessidade do planejamento do espaço como meio para se atingir as médias sociais, como o "verde por habitante", a "sustentabilidade", o "regular", o juridicamente "legal".

Concretizar tais representações perpassa a interiorização, na forma de uma consciência mistificada que se objetiva naquilo que são os espaços de representação, de maneira que o concebido e o vivido se defrontem numa forma direta que os englobe.

Nessa lógica da reprodução, que se aprofunda contemporaneamente, o espaço torna-se importante categoria de análise, pois se trata do conteúdo objetivo e subjetivo através do qual as formas financeiras se territorializam e ampliam o predomínio do capital sem substância nas promessas das dividas públicas que espaço fiduciário cumpre.

Por tanto, se tornam ficção e ficcionalizam o vivido dos moradores dessas áreas, estes que lutam e se debatem contra as formas veladas da expropriação entre o real e a fantasmagoria dos novos tempos, cada vez mais obscuros, cada vez mais negativos. 


\section{Bibliografia}


AB'SABER, Aziz Nacib - Geomorfologia do Sítio Urbano de São Paulo. São Paulo: Universidade de São Paulo - F.F.L.C.H. Boletim 219, 1957

ANDRADE, M. M. - Industrialização, Urbanização e Vida de Bairro na São Paulo Além-Tamanduateí. In: CARLOS, A. F. A \& OLIVEIRA, A. U. (orgs.) Geografias da Metrópole. São Paulo: Contexto, 2004

ARANTES, O. - Uma Estratégia Fatal. In: ARANTES, O.; VAINER, C.; MARICATO, E. - A cidade do pensamento único. Rio de Janeiro: Vozes, 2000

BAITZ, R. - A Propriedade contra a posse e a propriedade. São Paulo: Geousp ํo 22, 2007 - Uma aventura pelos elementos formais da propriedade: nas tramas da revitalização, mobilidade e abstração, à procura da contrapropriedade. São Paulo: Faculdade de Filosofia, Letras e Ciências Humanas, Universidade de São Paulo, Tese de Doutorado, 2012

BONDUK, Nabil - ROLNIK, Raquel - Periferia de São Paulo: reprodução do espaço como expediente de reprodução da força de trabalho - in MARICATO, Ermínia. - A Produção Capitalista da Casa (e da Cidade) no Brasil Industrial. São Paulo: Ed. Alfa-Ômega, 1982

BURGOS, R. - Periferias Urbanas da Metrópole de São Paulo: Territórios da Base da Indústria de Reciclagem no Urbano Periférico. São Paulo: Faculdade de Filosofia, Letras e Ciências Humanas, Universidade de São Paulo, Tese de Doutorado, 2008

CARLOS, A.F.A. - Espaço-Tempo na Metrópole. São Paulo: Contexto, 2001 
- A Reprodução da Cidade como Negócio. In: CARLOS, A. F.

A \& CARRERAS, C. - Urbanização e Mundialização. São Paulo: Contexto, 2005

CALDEIRA, T. P. do R. - Cidade de muros. São Paulo, Edusp/34, 2000

CHESNAIS, F. - A Mundialização do Capital. São Paulo: Xamã, 1996

COGGIOLA, O. \& KATZ, C. - Neoliberalismo ou Crise do Capital? - São Paulo:

Xamã, 1996

DAMIANI, Amélia Luisa - A Cidade (Des)Ordenada: Concepção e Cotidiano no

Conjunto Habitacional Itaquera I. São Paulo: Faculdade de Filosofia, Letras e Ciências Humanas, Universidade de São Paulo, Tese de Doutorado, 1993 - A Metrópole e a Indústria: reflexões sobre uma urbanização crítica. São Paulo: Terra Livre n.15, 2000

- Urbanização Crítica e situação geográfica. In

CARLOS, A. F. A. \& OLIVEIRA, A. U. de (orgs.) - Geografias de São Paulo: São Paulo, Contexto, 2004 - Espaço e Geografia: observações de método. São

Paulo: Faculdade de Filosofia, Letras e Ciências Humanas, Universidade de São Paulo, Tese de Livre Docencia, 2008

DEBORD, G. - A Sociedade do Espetáculo. Rio de Janeiro: Contraponto, 1997 FERNANDES, Florestan - A Revolução Burguesa no Brasil. São Paulo: Globo, 2005 (1975).

FIX, Mariana - Parceiros da Exclusão. São Paulo: Boitempo, 2001

FOUCAULT, M. - Microfísica do Poder. Rio de Janeiro: Edições Graal, 1984

HARVEY, D. - Los Limites del Capitalismo e la Teoria Marxista. México: Fondo de Cultura Económica, 1990 
- O Novo Imperialismo. São Paulo: Loyola, 2004

JAMESON, F. - A Cultura do Dinheiro. Petrópolis: Ed. Vozes, 2001

KOWARIK, L. - A Espoliação Urbana. Rio de janeiro: Paz e Terra, 1993

KOWARIK, L. \& ANT, C. - Cem Anos de Promiscuidade: O Cortiço na Cidade de São Paulo. In: KOWARIK, L. - As Lutas Sociais e a Cidade. São Paulo: Paz e Terra, 1994

KURZ, R. - Os Últimos Combates. Petrópolis, Editora Vozes: 1997

LACOSTE, Y. - A Geografia: isso serve, em primeiro lugar para fazer a guerra.

Campinas: Papirus, 2005

LefebVRE, H. - O Pensamento Marxista e a Cidade. Póvoa de Vazin: Ulisséia, 1972

- A Vida Cotidiana no Mundo Moderno. São Paulo: Ática, 1991 - A Revolução Urbana. Belo Horizonte: Humanitás, 1999 - O Direito à Cidade. São Paulo: Centauro, 2001 - Espaço e Política. Belo Horizonte: Ed. UFMG, 2008 - A "práxis": a relação social como processo. In Sociologia e Sociedade: Leituras de Introdução à Sociologia. FORACCHI, M. M. \& MARTINS, J. S. (organizadores). Rio de Janeiro, Livros Técnicos e Científicos, 1980

LENIN, V. I. - Imperialismo, Fase Superior do Capitalismo. São Paulo: Global, 1979

MARICATO, E. - Auto-Constução, a Arquitetura Possível. In: MARICATO, E. (org.) - A Produção Capitalista da Casa (e da Cidade) no Brasil Industrial. São Paulo: Ed. Alfa-Ômega, 1982

MARTINS, F. E. da S. - A (Re)Produção Social da Escala Metropolitana: um 
estudo sobre a abertura de capitais nas incorporadoras e sobre 0 endividamento imobiliário em São Paulo. São Paulo: Faculdade de Filosofia, Letras e Ciências Humanas, Universidade de São Paulo, Tese de Doutorado, 2010

MARTINS, José de Souza - Capitalismo e Tradicionalismo: Estudo Sobre as Contradições da Sociedade Agrária no Brasil. São Paulo: Pioneira, 1975 - Fronteira: A Degradação do Outro nos Confins do

Humano. São Paulo: HUCITEC, 1997 - O Cativeiro da Terra. São Paulo: Hucitec, 2004 MARX, Karl - O Capital (Volume II, Livro 1). Rio de Janeiro: Civilização Brasileira, 1980 - O Capital (Volume IV, Livro 3). Rio de Janeiro: Civilização

Brasileira, 1980 - A Miséria da Filosofia. São Paulo: Global, 1985 - Manuscritos Econômico-Filosóficos. São Paulo, Boitempo, 2004

MARX, K. \& ENGELS, F. - A Ideologia Alemã. São Paulo: Boitempo, 2007 MENDES, R. da S. - Penha: Porta Oriental da Cidade de São Paulo. In: AZEVEDO, A. - A cidade de São Paulo - v.IV. São Paulo: Cia. Editora Nacional, 1958

MEYER, R. M. P.; GROSTEIN, M. \& BIDERMAN, C. - São Paulo: Metrópole. São Paulo: Edusp \& Imprensa Oficial do Estado, 2004 MONBEIG, Pierre - Pioneiros e Fazendeiros de São Paulo. São Paulo: HUCITEC, 1984

OLIVEIRA, F. de - Crítica à Razão Dualista. São Paulo: Boitempo, 2003 (1973) - Elegia para uma Re(li)gião. São Paulo: Boitempo, 2008 (1977) 
PEREIRA, P. C. X. - Dinâmica imobiliária e metropolização: a nova lógica do crescimento urbano em São Paulo. Barcelona: Scripta Nova (Revista Eletrónica de Geografía e Ciencias Sociales) ํำ194, 2005

PRADO JUNIOR, C. - A Cidade de São Paulo. São Paulo: Brasiliense, 1998 (1943)

ROLNIK, RAQUEL - A Cidade e a Lei: legislação, política urbana e territórios na cidade de São Paulo. São Paulo: Studio Nobel/FAPESP, 2003

ROBIRA, R. T. - Áreas Metropolitanas, Espaços Colonizados - In: CARLOS, A.

F. A \& CARRERAS, C. (orgs.) - Urbanização e Mundialização. São Paulo: Contexto, 2005

SAMPAIO, M. R. A.; PEREIRA, P. C. X. - Habitação em São Paulo. São Paulo, Estudos Avançados v. 17 № 48, 2003. Disponível em http://www.researchgate.net/publication/265940075 Globalizao e Desenvolviment o Imobilirio tendncias de reestruturao. Acesso 06/2014

SANTOS, M. - Por uma Economia Política da Cidade: o caso de São Paulo. São Paulo: HUCITEC/EDUC, 1994 - A Natureza do Espaço. São Paulo: Edusp, 2002

SÃO PAULO - Departamento de Águas e Energia Elétrica (DAEE) - Plano Diretor de Macrodrenagem da Bacia do Alto Tietê. São Paulo: Governo do Estado de São Paulo, 1999

- Departamento de Águas e Energia Elétrica (DAEE) PROGRAMA DE RECUPERAÇÃO DAS VÁRZEAS DA BACIA DO ALTO TIETÊ - Parque Várzea do Tietê - PLANO DIRETOR DE REASSENTAMENTO. São Paulo: Governo do Estado de São Paulo, 2010a 
- PROGRAMA dE RECUPERAÇÃO DAS VÁRZEAS DA BACIA

DO ALTO TIETÊ - ETAPA I - INFORME DE GESTÃO AMBIENTAL E

SOCIAL DO PROGRAMA. São Paulo: Governo do Estado de São Paulo, $2010 \mathrm{~b}$

SEABRA, O. C. de L. - Meandros dos rios nos meandros do poder - São Paulo: Faculdade de Filosofia, Letras e Ciências Humanas - Universidade de São Paulo, Tese de Doutorado, 1987 - Pensando o processo de valorização e a geografia. São

Paulo: Associação de Geógrafos Brasileiros (AGB), Boletim Paulista de Geografia ํำ66, 1988 - Economia política do espaço: a reestruturação da bacia do Alto Tietê - In: CARLOS, A. F. A \& CARRERAS, C. - Urbanização e Mundialização. São Paulo: Contexto, 2005 - Futebol, do ócio ao negócio. In: DEBORTOLI, J. A., MARTINS, M. F. A., MARTINS, S. M. Infâncias na Metrópole. Belo Horizonte: Ed. UFMG, 2008

SILVA, M. A. T. - O Ambiente Fluvial das Várzeas no Espaço da Metrópole.

São Paulo: Faculdade de Filosofia, Letras e Ciências Humanas, Universidade de São Paulo, Dissertação de Mestrado, 2009 SINGER, P. - Uso do Solo Urbano na Economia Capitalista. In: MARICATO, E. A Produção Capitalista da Casa (e da Cidade) no Brasil Industrial. São Paulo: Ed. Alfa-Ômega, 1982

WASHINGTON, D.C - BANCO INTERAMERICANO DE DESENVOLVIMENTO (BID) - Reasentamiento involuntario en los proyectos del BID: Principios y lineamientos: Washington, D.C. ,1999 


\section{Apêndice}

Mapas 1 e 2 


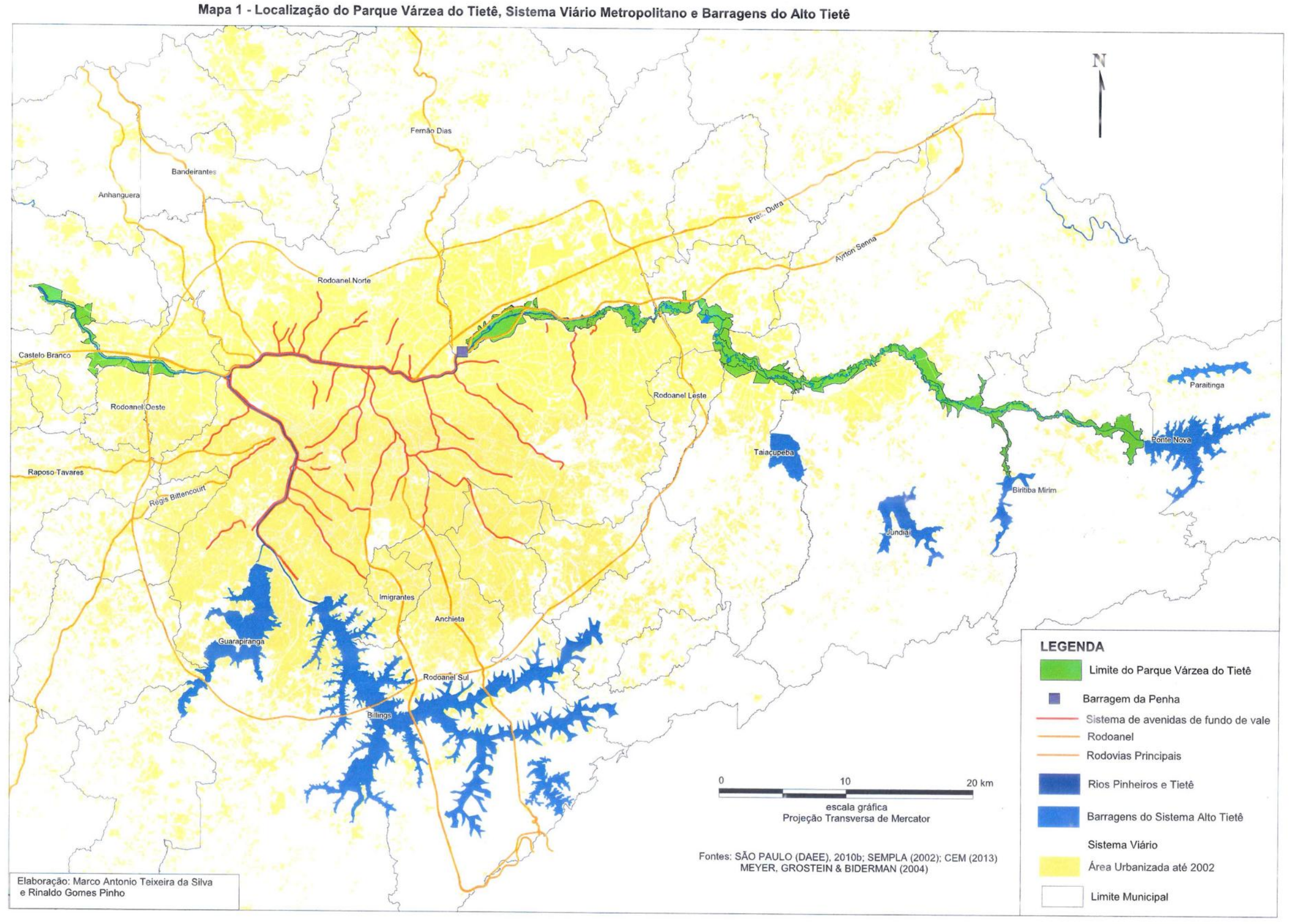


Mapa 2: Mapa Detalhado do Sistema Viário Metropolitano

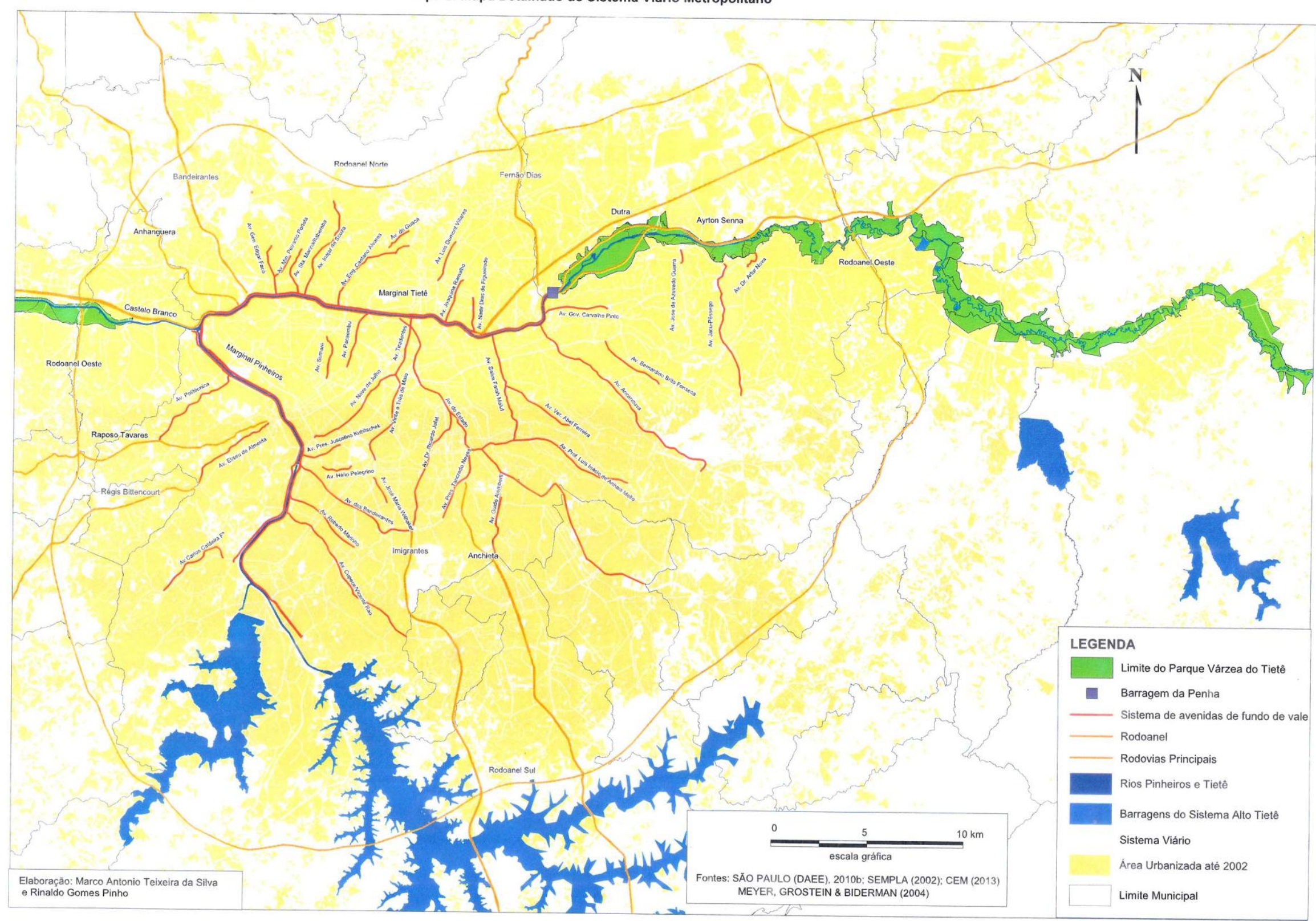


Anexo 1

Folheto Operação Defesa das Águas 
Como faço para jogar fora lixo ou entulho?

O lixo deve ser colocado em sacos plásticos e deixado na calçada para a coleta. O mesmo vale para pequenas quantidades de entulho (sacos até 50 litros). Para quantidades maiores, coloque em caçambas autorizadas.

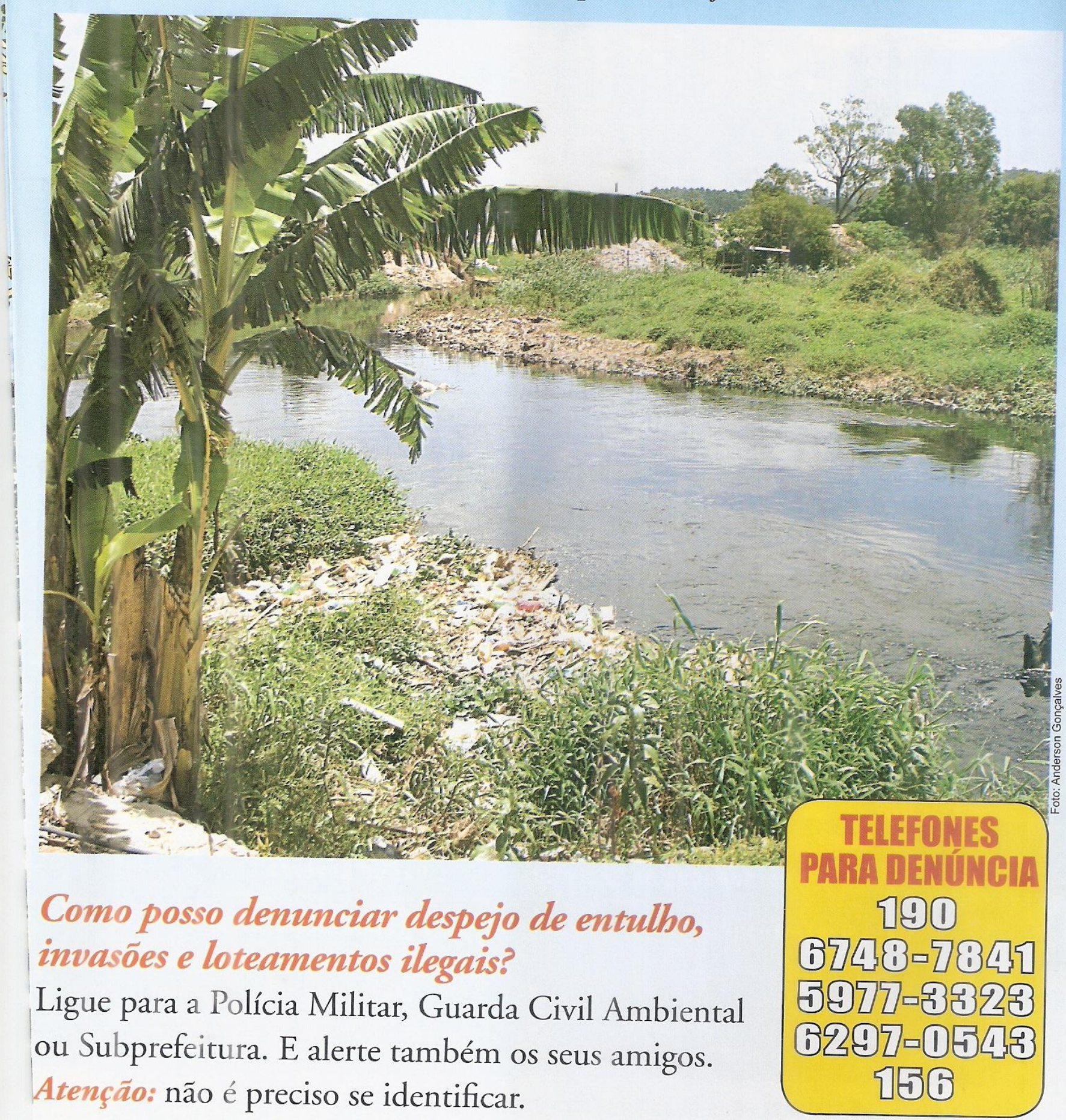


Oneração Defesa das Águas

Derrubar árvores para

construir é crime? é crime ambiental grave. Poda e remoção, só com autorização da Prefeitura.

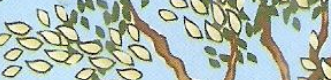

$009^{\circ}$

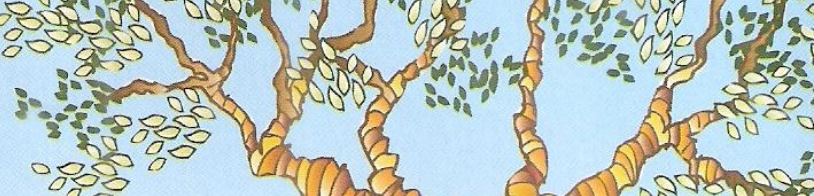
Fiscais da Prefeitura
percomem os
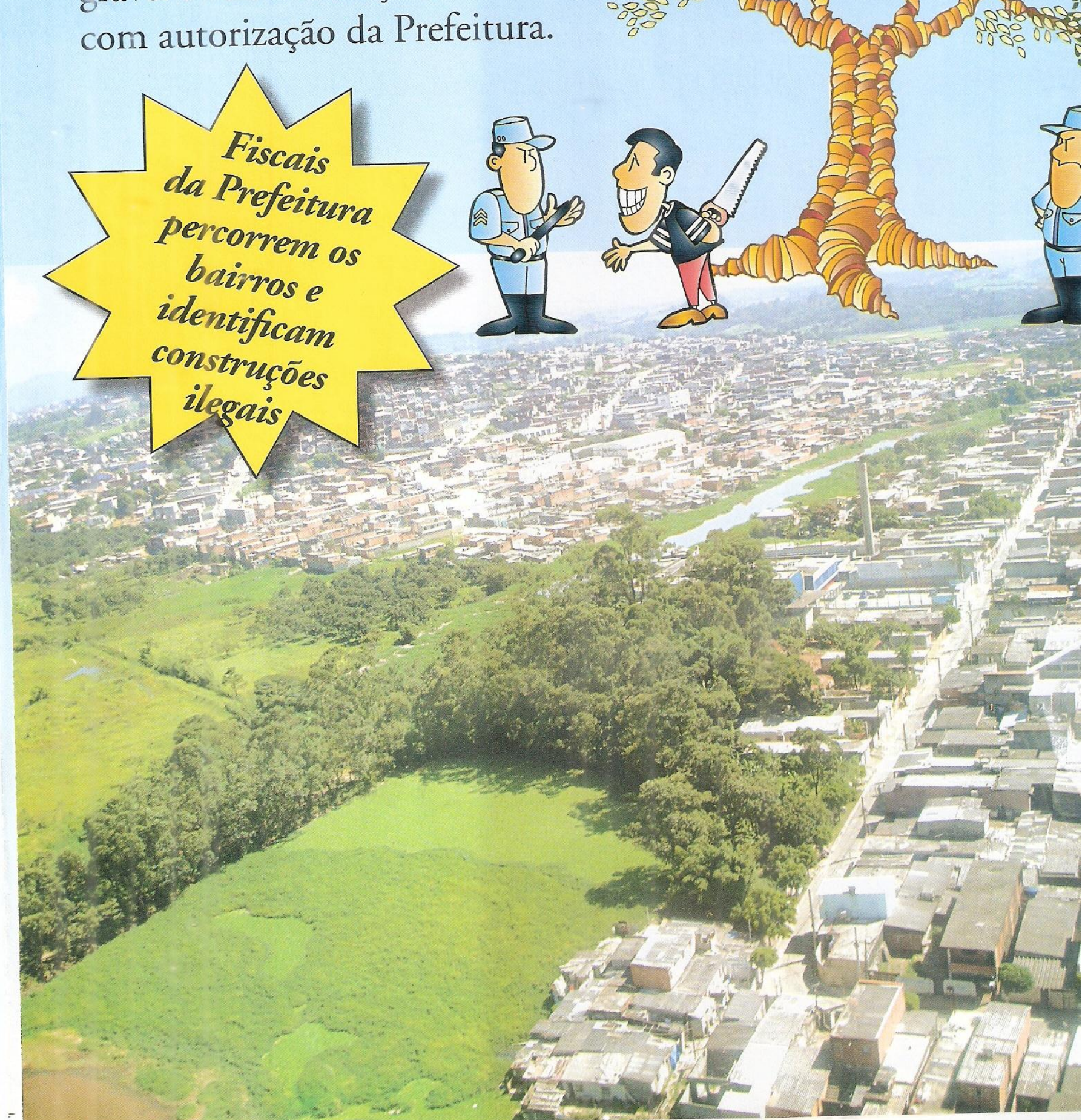
Posso reformar ou ampliar minha casa? Consulte a Subprefeitura. Algumas ampliações e reformas são permitidas, outras não.

\section{O que me dá garantia de propriedade} de meu imóvel?

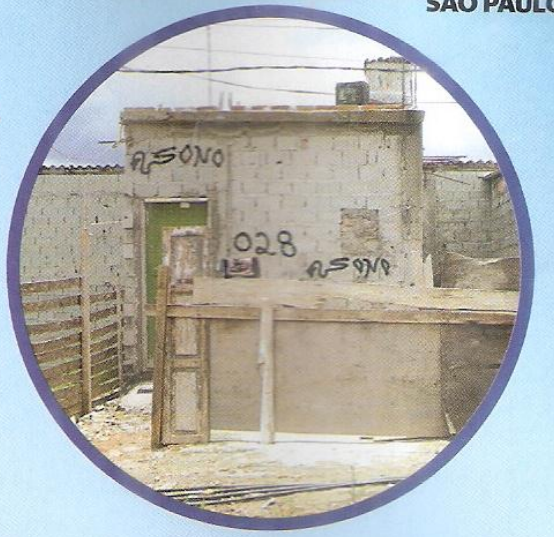

Você precisa ter uma escritura registrada num cartório de imóveis.

Atenção: a escritura garante a propriedade, mas não dá o direito de construir.

\section{Posso criar animais na minha propriedade?}

Em área urbana, é PROIBIDA a criação de porcos. Cães e gatos são permitidos, mas no máximo 10 numa residência. Outras aves domésticas podem ser criadas, mas em cercados fechados com tela. Animais de grande porte, só em locais adequados e sua circulação só em ruas não pavimentasdas.

\section{Posso construir na beira do rio ou do córrego?}

Não. É crime ambiental e pode dar multa, prisão e a demolição da casa.

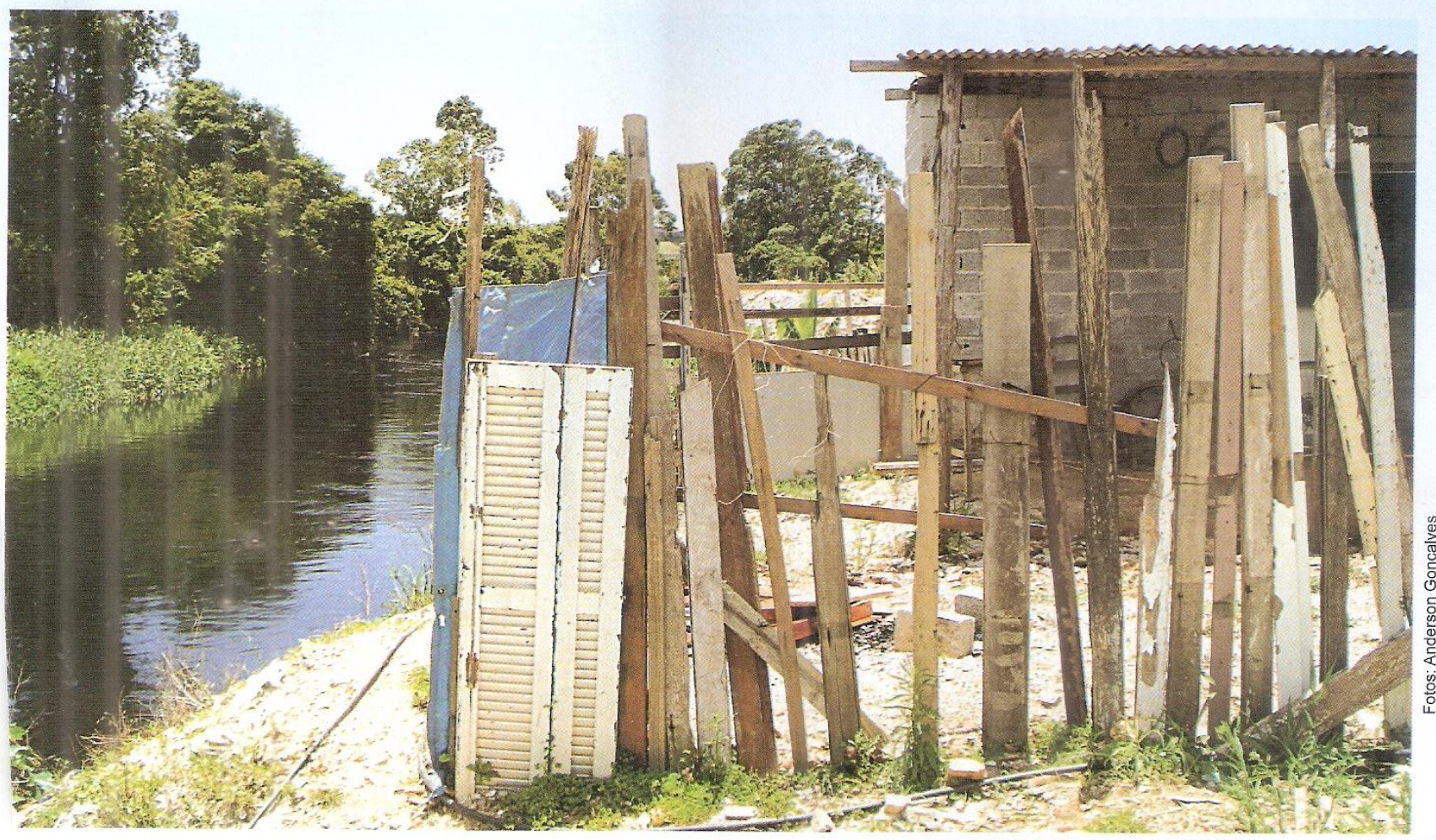


Operação Defesa das Águas

Se a casa onde moro estiver irregular, vão me expulsar de lá de repente?

Não. Os moradores só serão removidos se necessário. A Prefeitura estudará cada caso separadamente. E tentará regularizar os lotes.

Moro na Várzea do Rio Tietê há muitos anos. Isso não me dá o direito de ficar?

Construção antiga não significa construção regular. Só a Subprefeitura

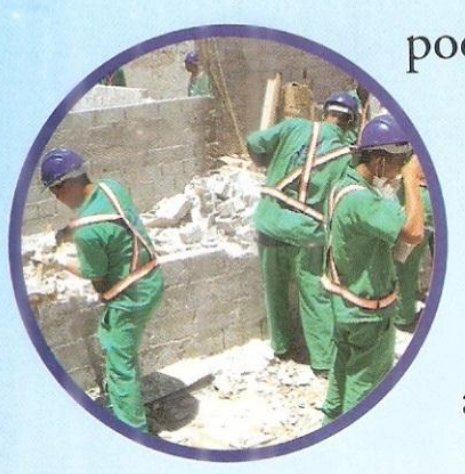

pode dizer se a sua propriedade é regular.

$E$ se eu colocar uma laje sobre a construção? Se a obra for irregular, será derrubada do mesmo jeito. A Guarda Sua construção será demolida. Muitas casas e ampliações já foram derrubadas.

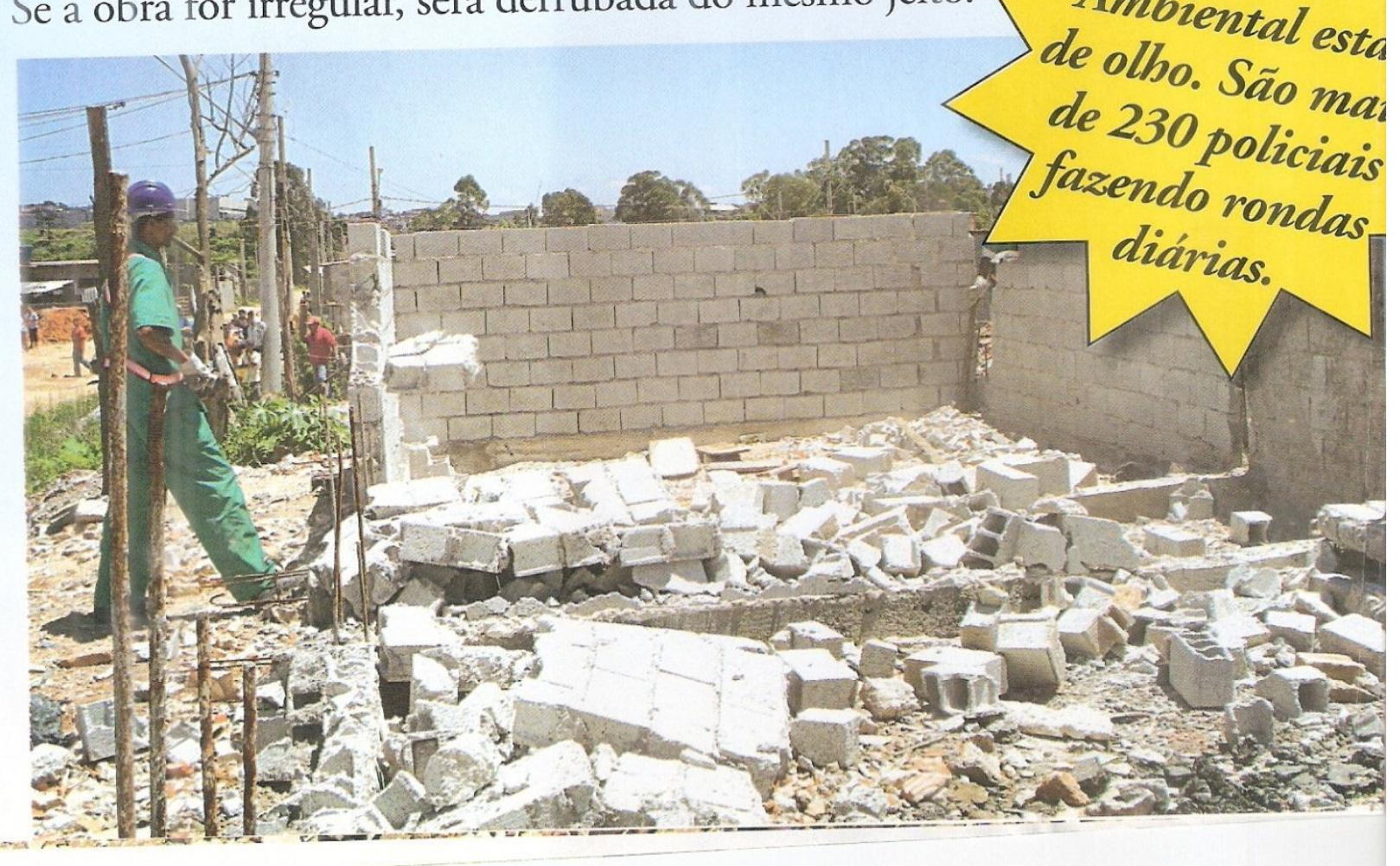




\section{TIRE AGORA AS SUAS DÚVIDAS}

\section{O que é Operação Defesa das Águas?} É um conjunto de medidas para preservar, proteger e controlar córregos, represas, nascentes e matas de invasões, construçóes irregulares e qualquer ato que signifique dano ao meio ambiente.

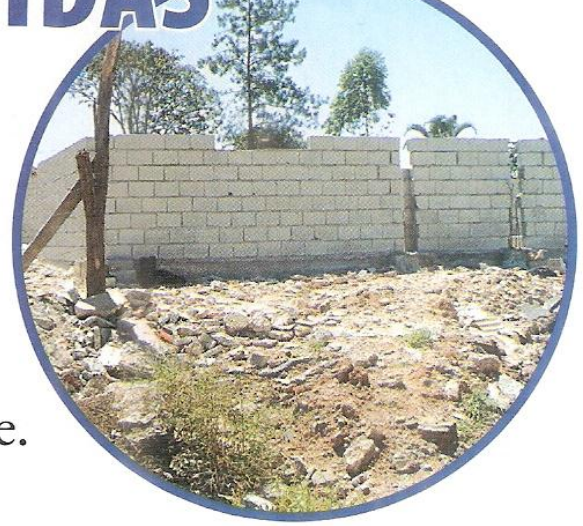

Como posso saber se a casa que vou comprar está regular? Consulte a sua Subprefeitura (veja o endereço na última página). Nunca compre uma casa nem terreno ou comece uma construção sem consultar a Subprefeitura. Você pode perder o dinheiro investido e ter a casa demolida.

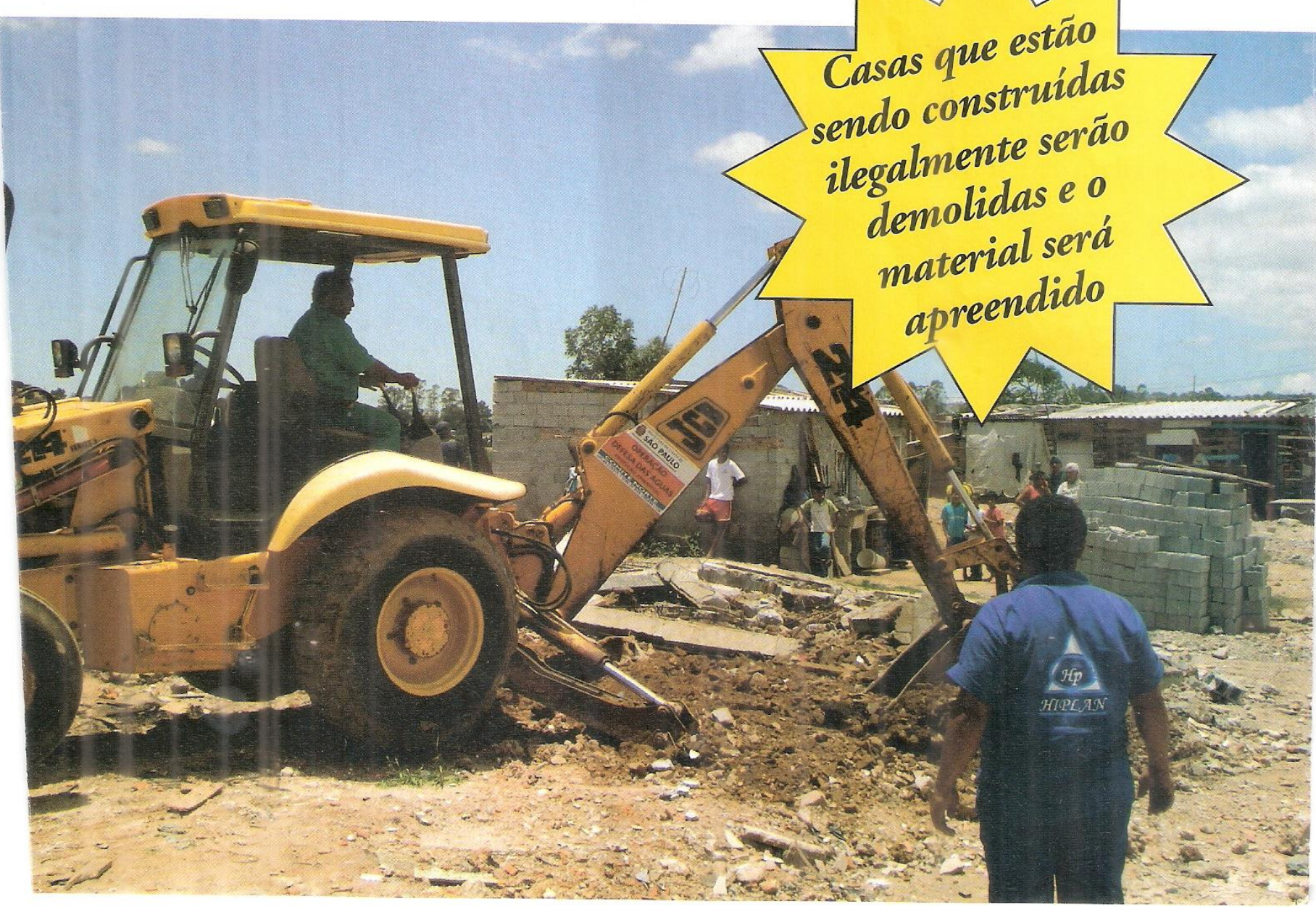




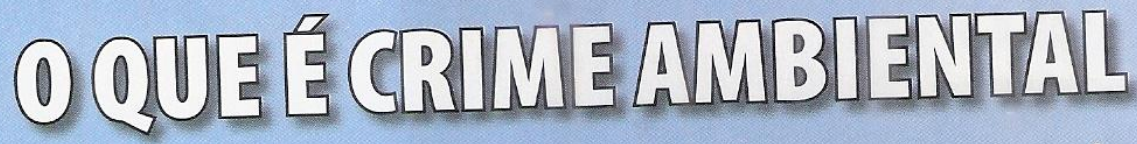

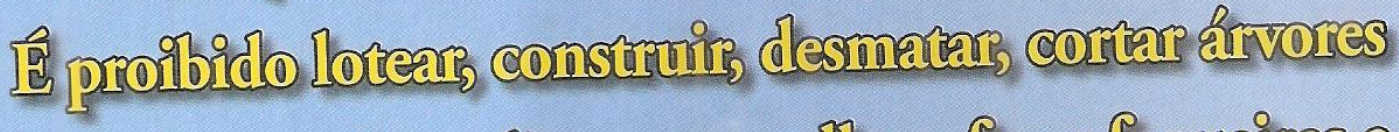
or arbustos, jogar liv:o or entur tho e faver fogueiras e

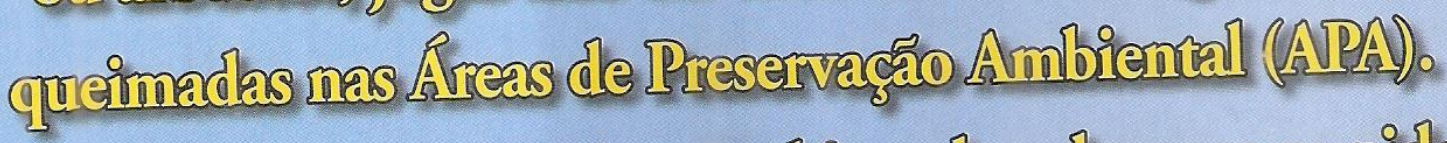
Pessoas que cometem erime amibiential poréem ser purnichas com multas e ate proisåo.
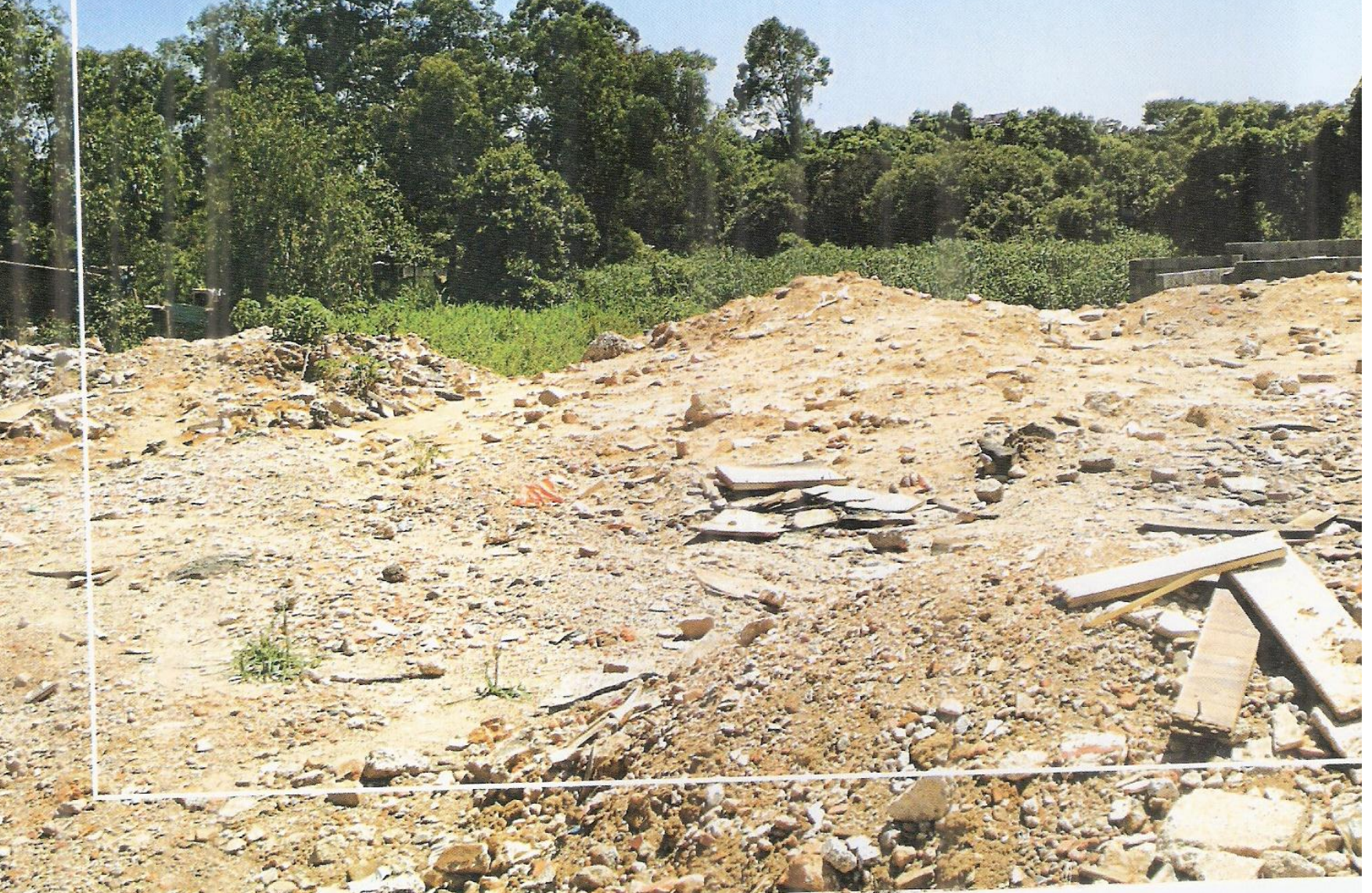


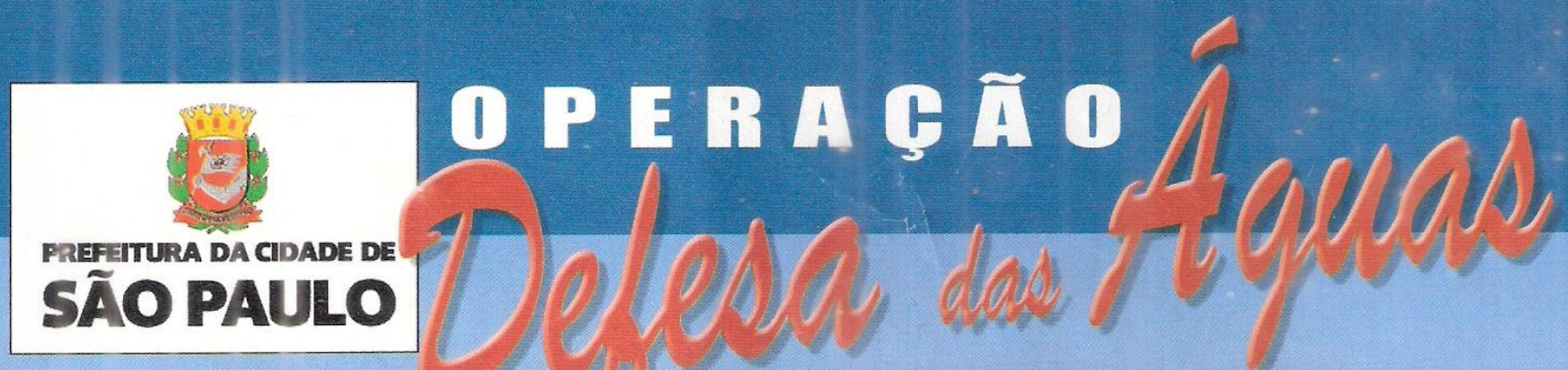

Informarão à Comunidade

$y$
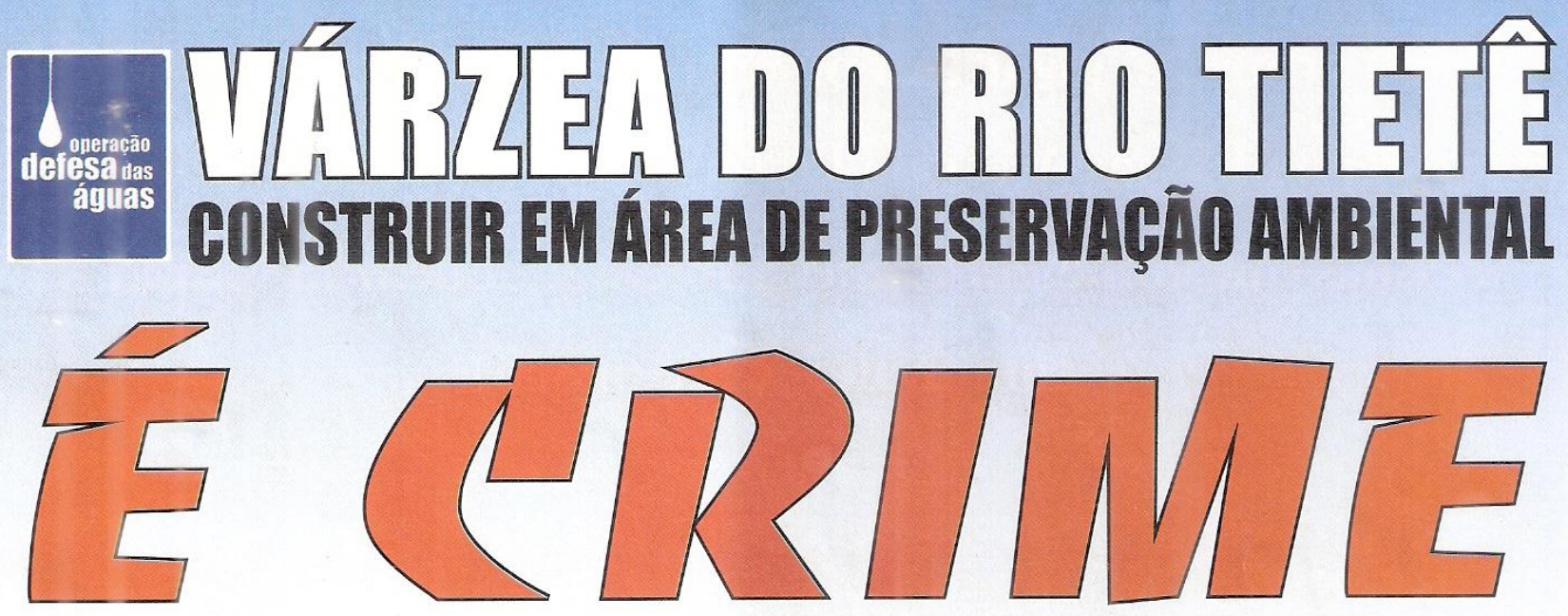

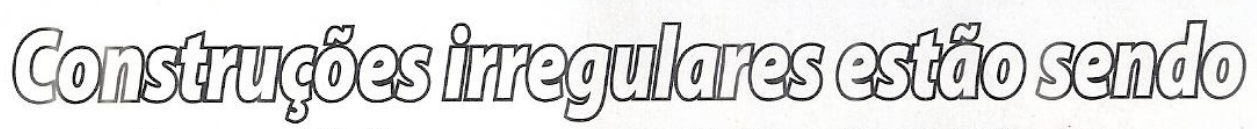

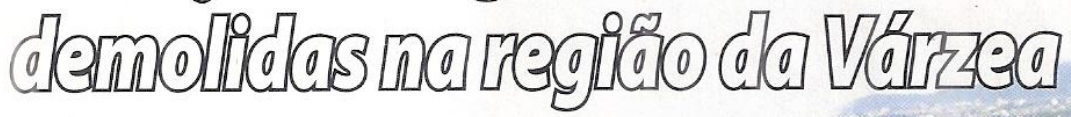

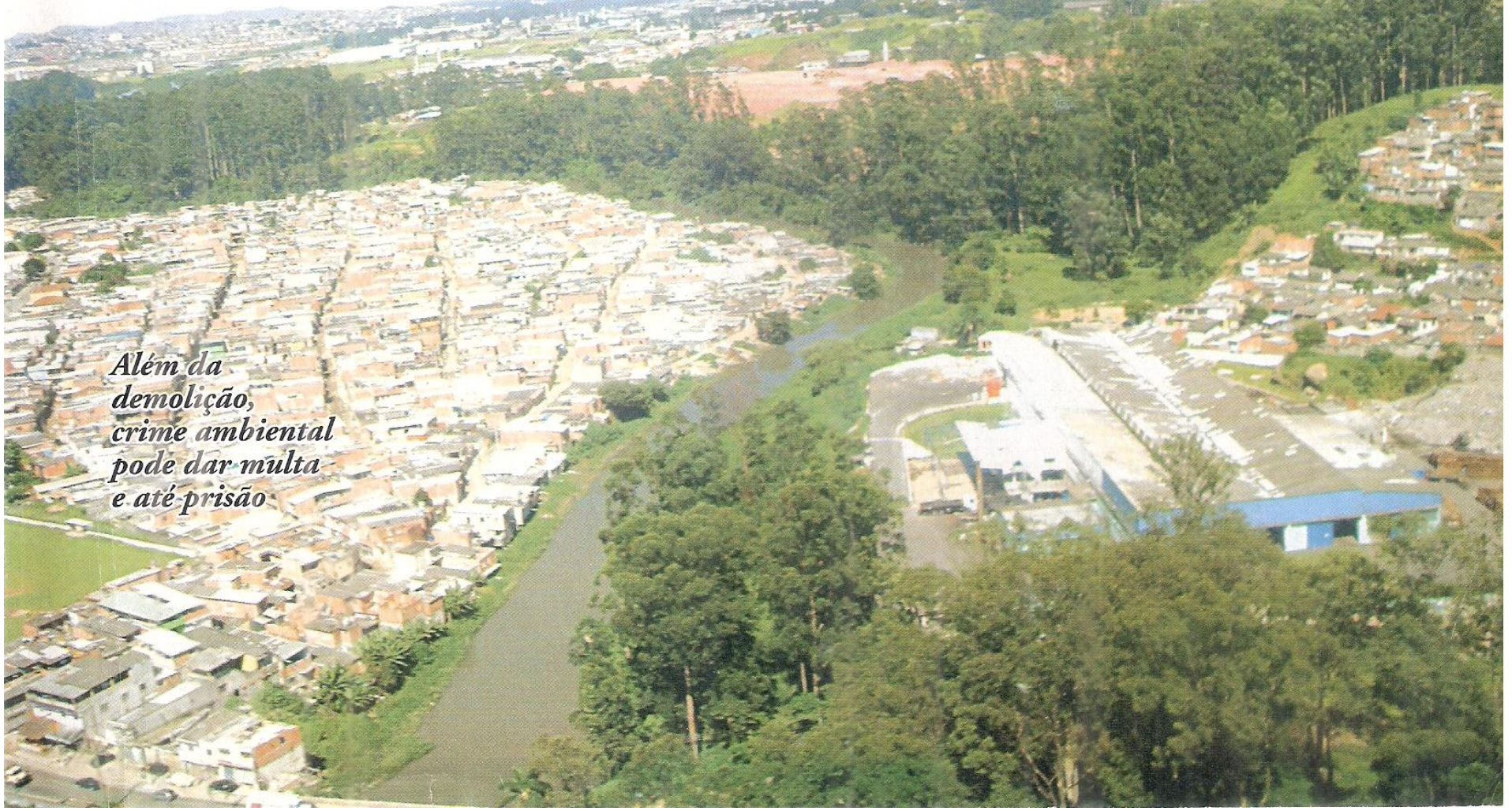




\section{Operação na Várzea do Tietê}

\section{Combate severo ao despejo de lixo e entulho e às construções illegais}

stá em curso, desde
dezembro de 2007 ,
a Operaçáo Defesa das Águas, conjunto de medidas da Prefeitura e do Governo do Estado para controlar e recuperar áreas de mananciais e represas. Duzentos e trinta homens da Guarda Ambiental patrulham as margens em carros e motos para prevenir construções ilegais. Pontosde-venda de material de construção e fábricas de blocos e tijolos na área estão sendo fechados. Caminhóes com material circulando na região, apreendidos. Quem faz casas novas tem a construção demolida - já aconteceu algumas vezes. Os locais foram mapeados e estão sendo visitados. Essas ações são permanentes, para controlar as invasóes, evitar a destruição do ambiente e não deixar a situação piorar.

\begin{tabular}{l} 
Prefeito \\
Gilberto Kassab \\
\hline EXPEDIENTE \\
Jornalista responsável \\
Sérgio Rondino-MTB 8367 \\
Produção editorial \\
Grupo CBI
\end{tabular}

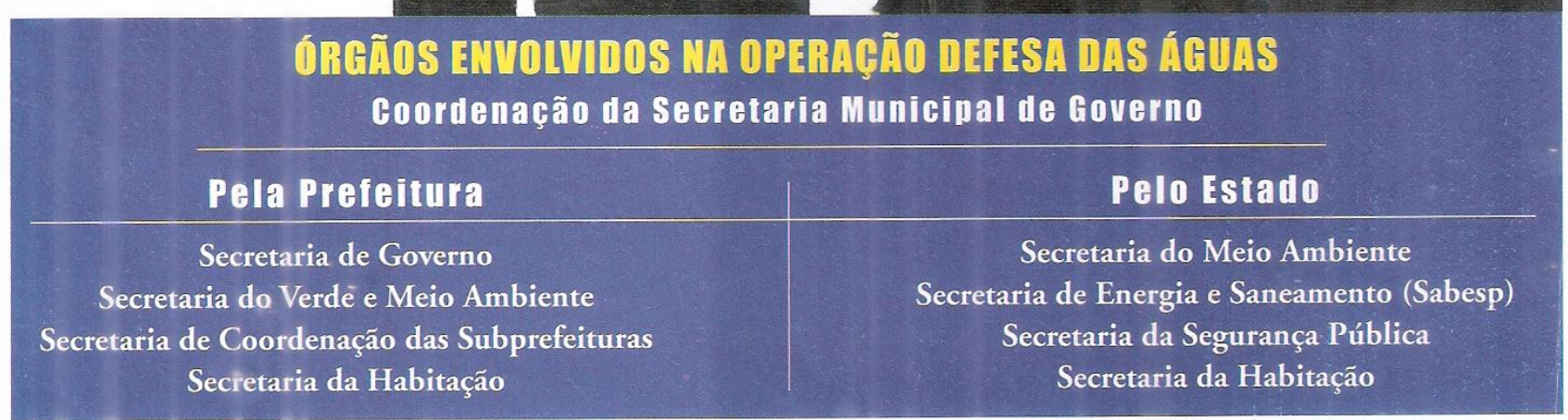

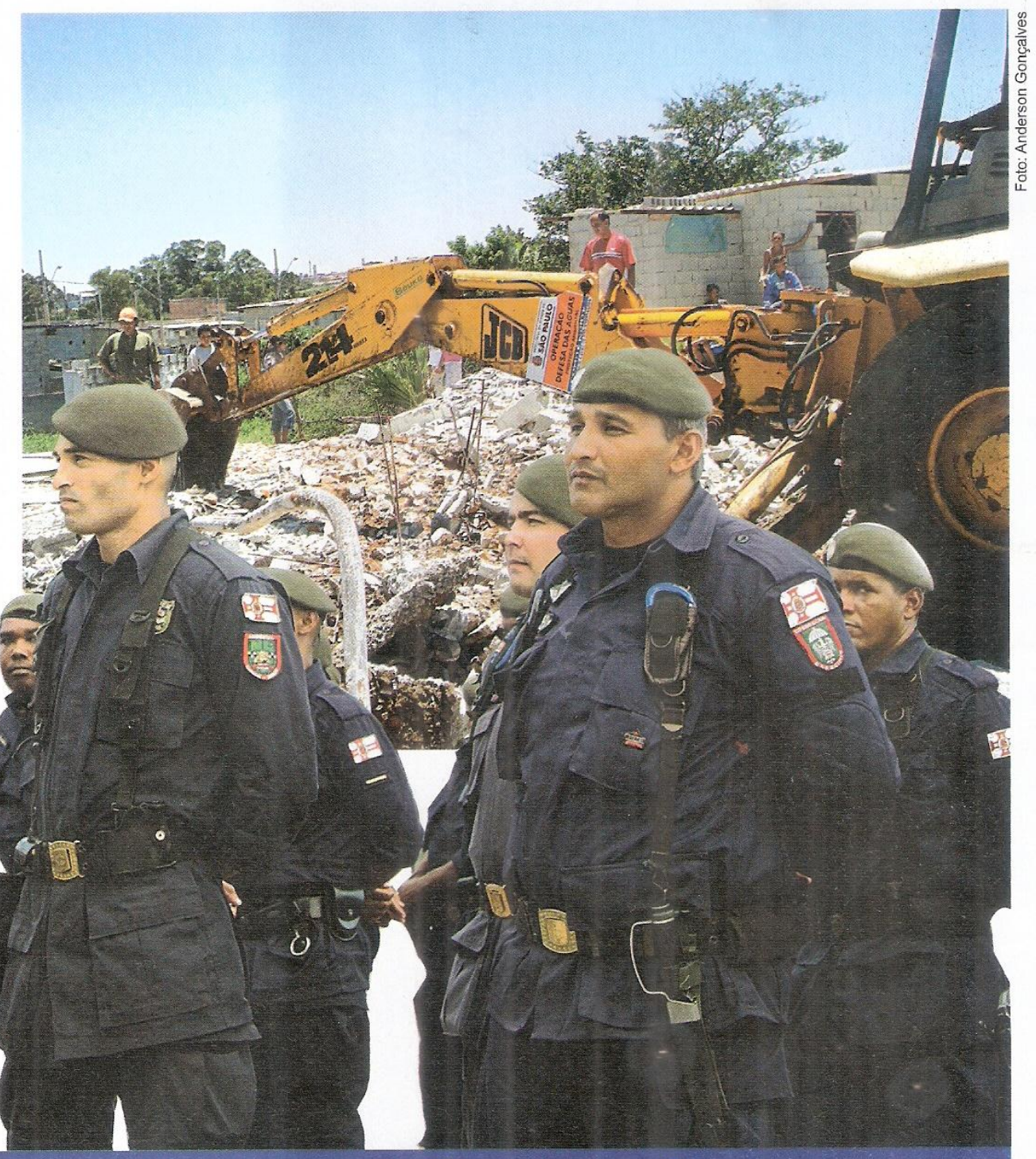




\section{Anexo 2}

Perímetro Parque Várzea do Tietê Departamento de Águas e Energia (DAEE) (adaptado do documento original) 
LINHA DE PERÍMETRO DO PARQUE VÁRZEAS DO TIETÊ:

> Iniciando pela Estrada do Casteluche;

$>\quad$ Segue paralelo a Avenida Eduardo Sabino de Oliveira;

> Segue paralelo a Rua Benedito Bastos Barreto;

$>\quad$ Segue paralelo a Rua Matilde Marchesi;

$>\quad$ Continua pela Rua Edalberto dos Santos;

$>\quad$ Continua pela Rua Parnaíba;

> Segue Margeando o Rio Tietê até Estrada Juscelino K. de Oliveira

$>\quad$ Segue paralela a Rua Emílio Cardoso Aires;

> Segue margeando construção até Rua Francisco Cirilo;

$>\quad$ Construções até Rua António Joaquim de Carvalho;

$>\quad$ Segue pela Rua dos Girassóis;

$>\quad$ Segue pela Rua Leonel Azevedo;

> Construções margeando Parque do Estado;

$>\quad$ Segue paralelo a Rua José Martins Lisboa; 
$>\quad$ Segue pela Rua Ubapitanga;

> Segue até Rua Cosme Damião;

> Segue pela Rua Cachoeira Itaguassava;

$>\quad$ Vira na $4^{\underline{a}}$ rua e segue margeando as casas até $1^{\text {a }}$ rua a frente da rua Tietê;

$>\quad$ Desce até o fim da rua, vira a esquerda e segue pela Rua Tietê;

$>\quad$ Segue até viela paralela a Rua Salsa Parrilha;

$>\quad$ Da viela segue até a Estrada da Biacica;

$>\quad$ Segue até Rua Tito de Lemos;

> Segue até Rua Forte de Aicobaça, até a Rua Apiú-quiribó;

$>\quad$ Desce até a Rua Bernardo Chaves Cabral;

$>\quad$ Sobe pela Rua Manuel Barbosa dos Reis;

> Sobe duas Ruas e atravessa a quadra até a Rua Valentino Lopes;

$>\quad$ Segue até a Rua Agostinho Alves Marinho;

$>\quad$ Segue até a Rua Rio Manuel Alves;

$>\quad$ Segue pela Rua Gruta das Princesas;

> Segue até último quarteirão até Rua Freguesia das Varges;

$>\quad$ Segue até Rua Abacatuaja; 


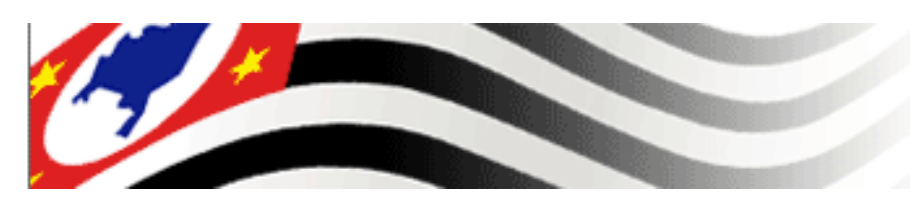

> Segue entre as Ruas Confluência da Forquilha e Rua Cachoeira Mangaval;

$>\quad$ Segue até a Rua Adobe;

$>\quad$ Segue até Rua Luis Botelho Mourão;

$>\quad$ Segue até quarteirão com a Rua Diogo Gonçalves Laco;

$>\quad$ Sobe até a Rua Francisco Cubas Ferreira virando a direita;

$>\quad$ Segue e vira a direita na Rua Duarte Martins Mourão;

$>\quad$ Segue e vira a esquerda na Rua Canacatagê;

$>\quad$ Segue e vira a direita na Rua João Barbosa Rabelo;

$>\quad$ Segue e vira a esquera da Rua Canacatagê;

> Segue e vira a direita na Rua Capachós;

$>\quad$ Segue e vira a esquerda na divisa do CÉU Três Pontes;
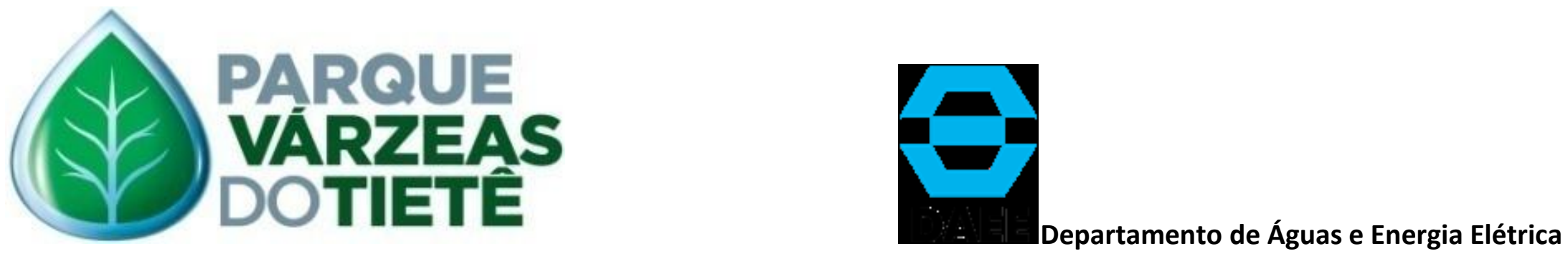


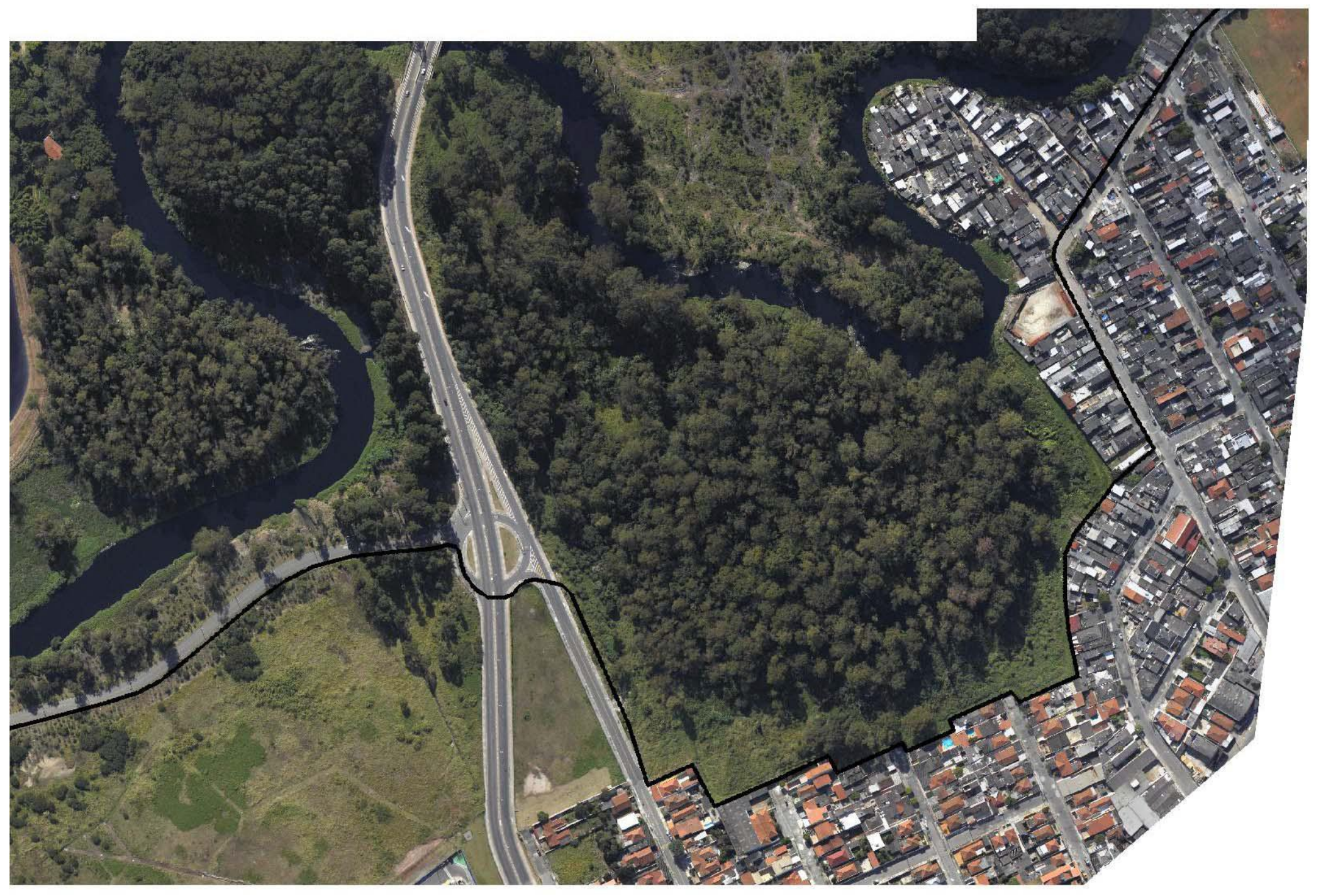




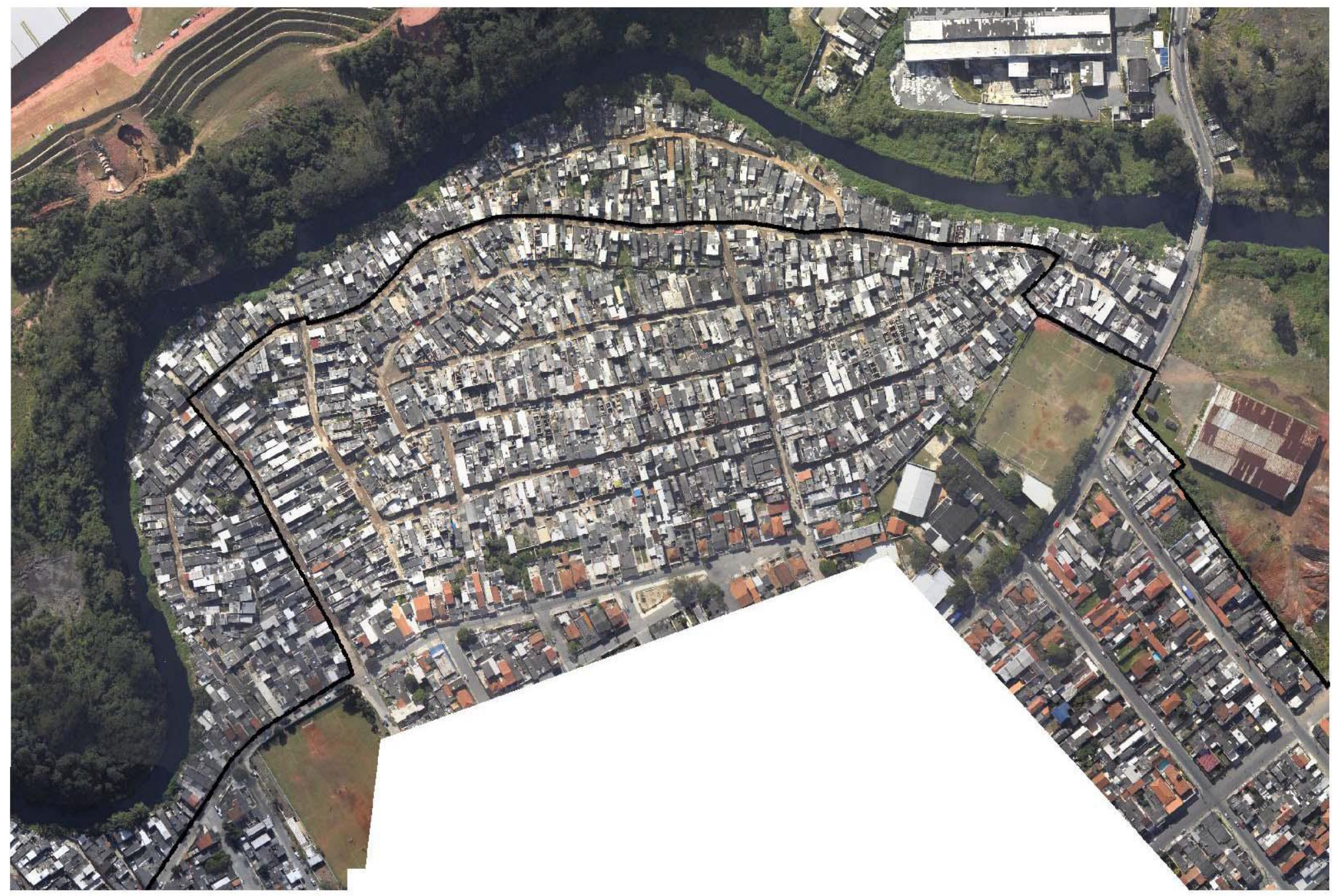




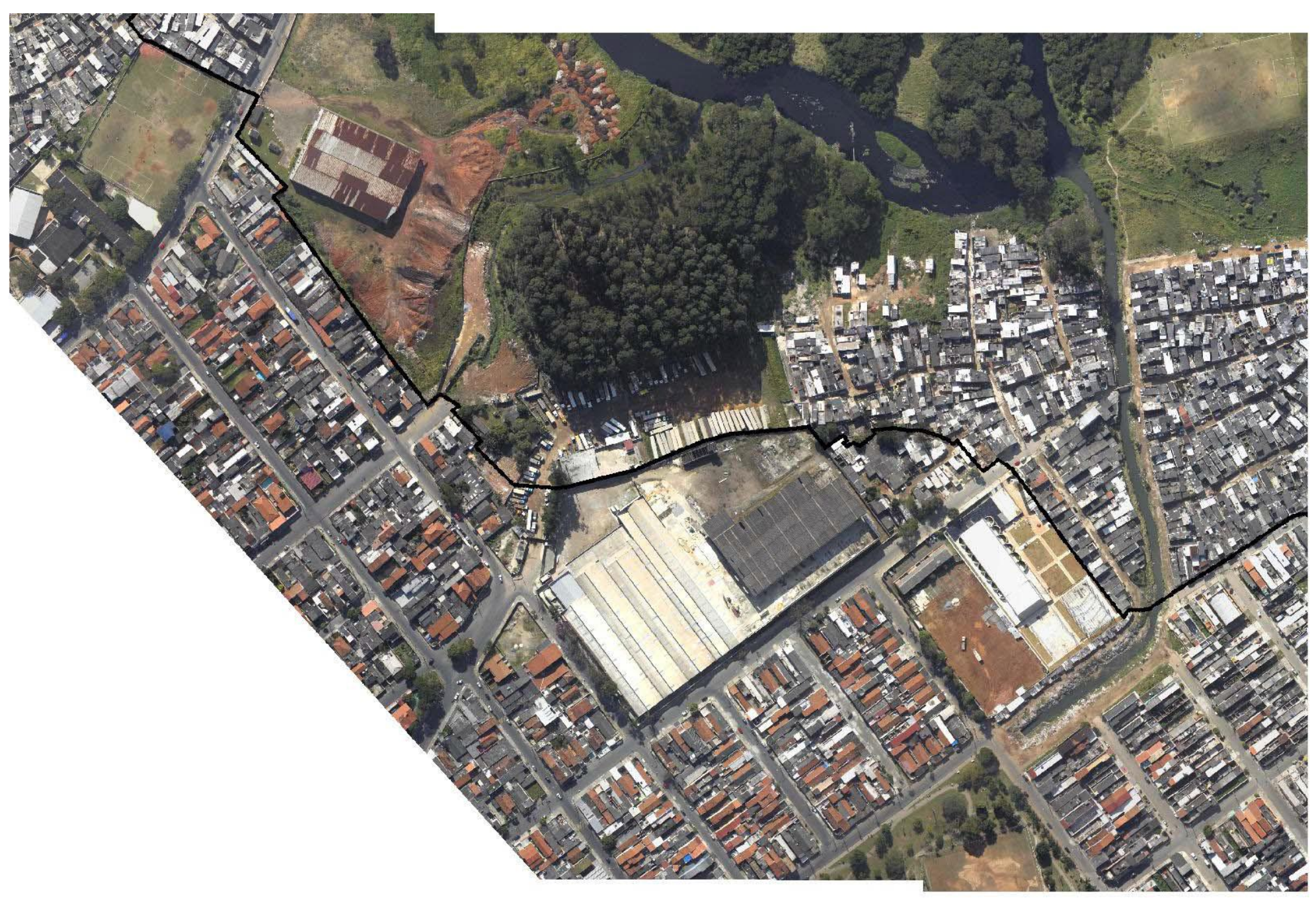




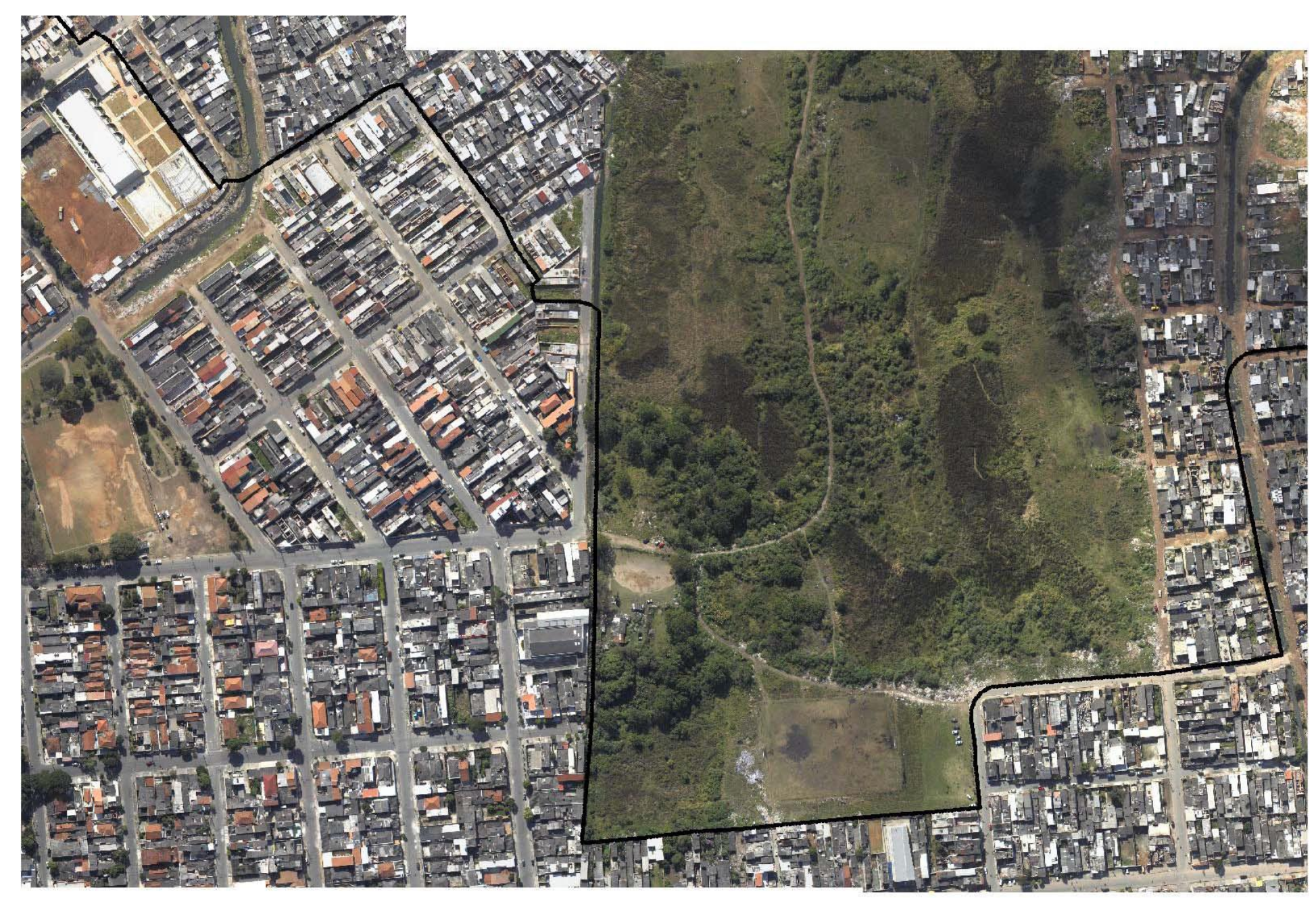




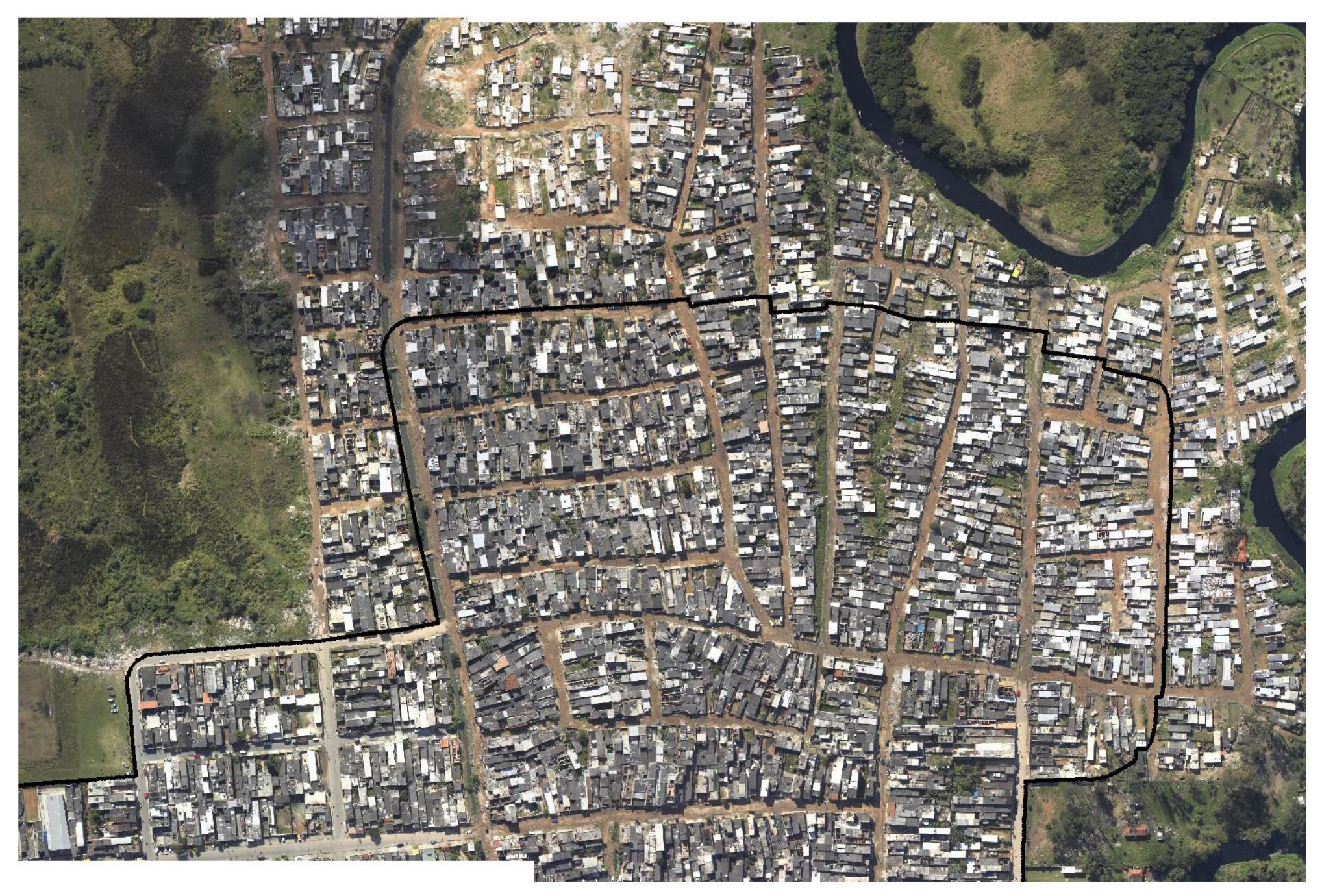




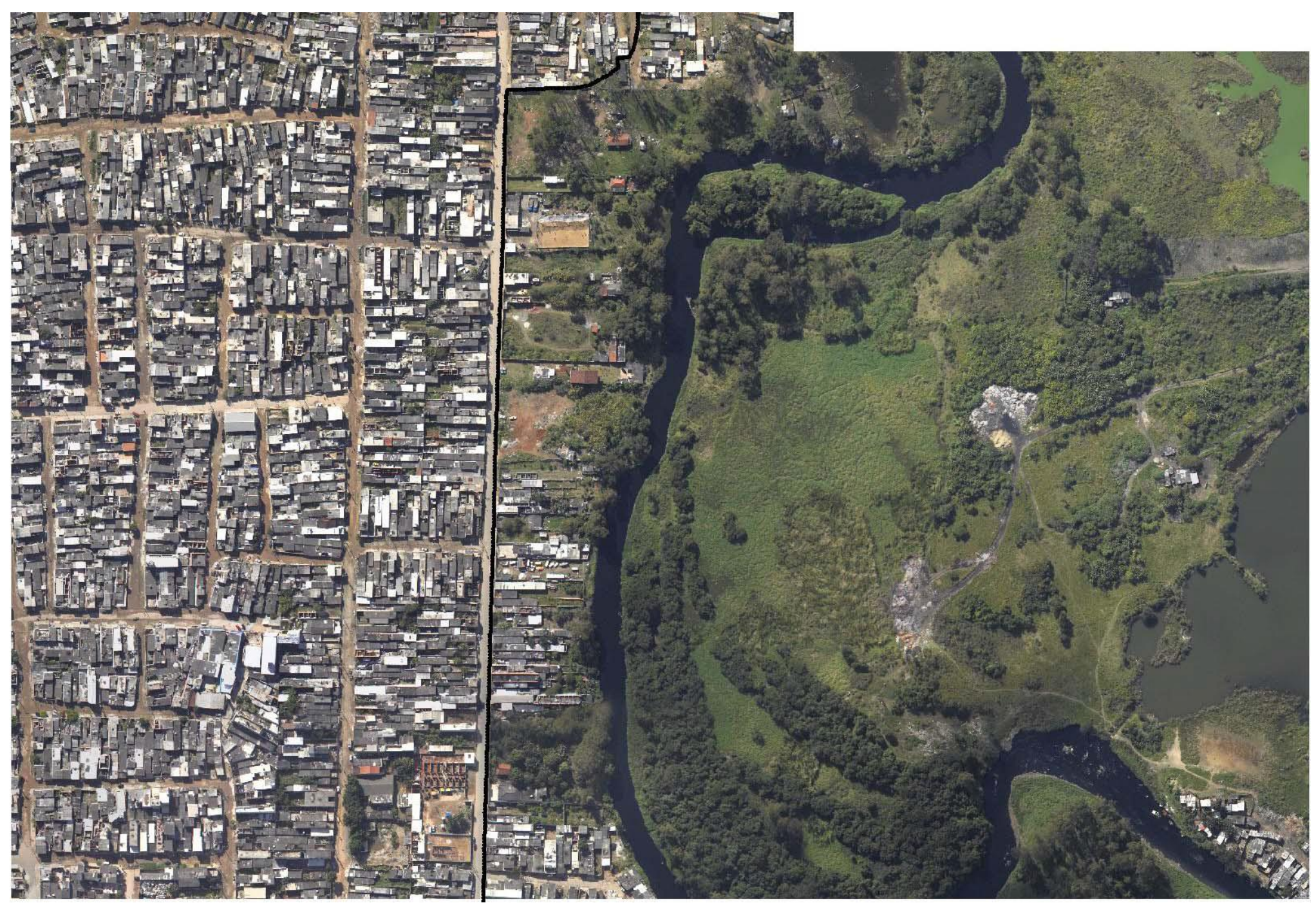




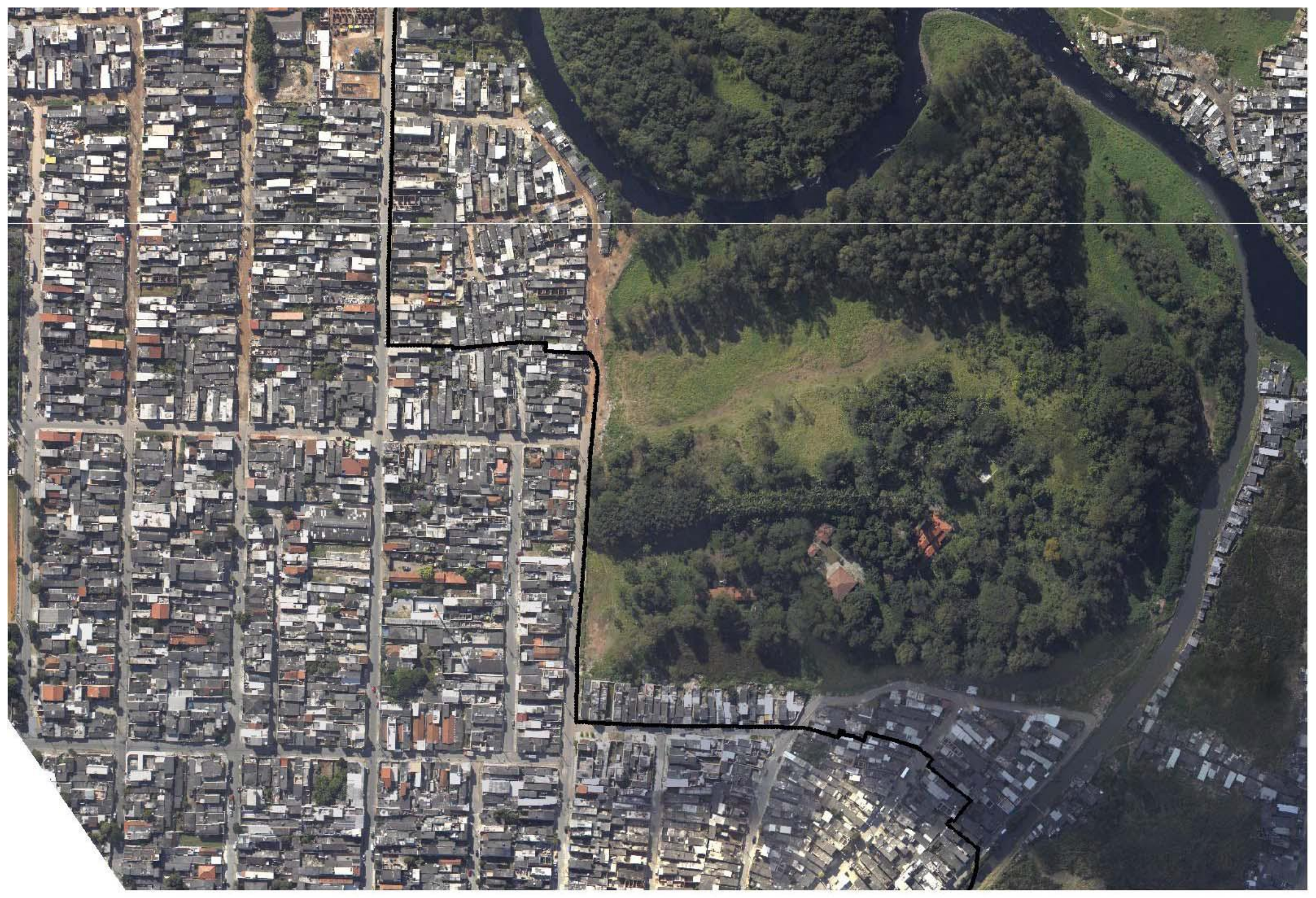




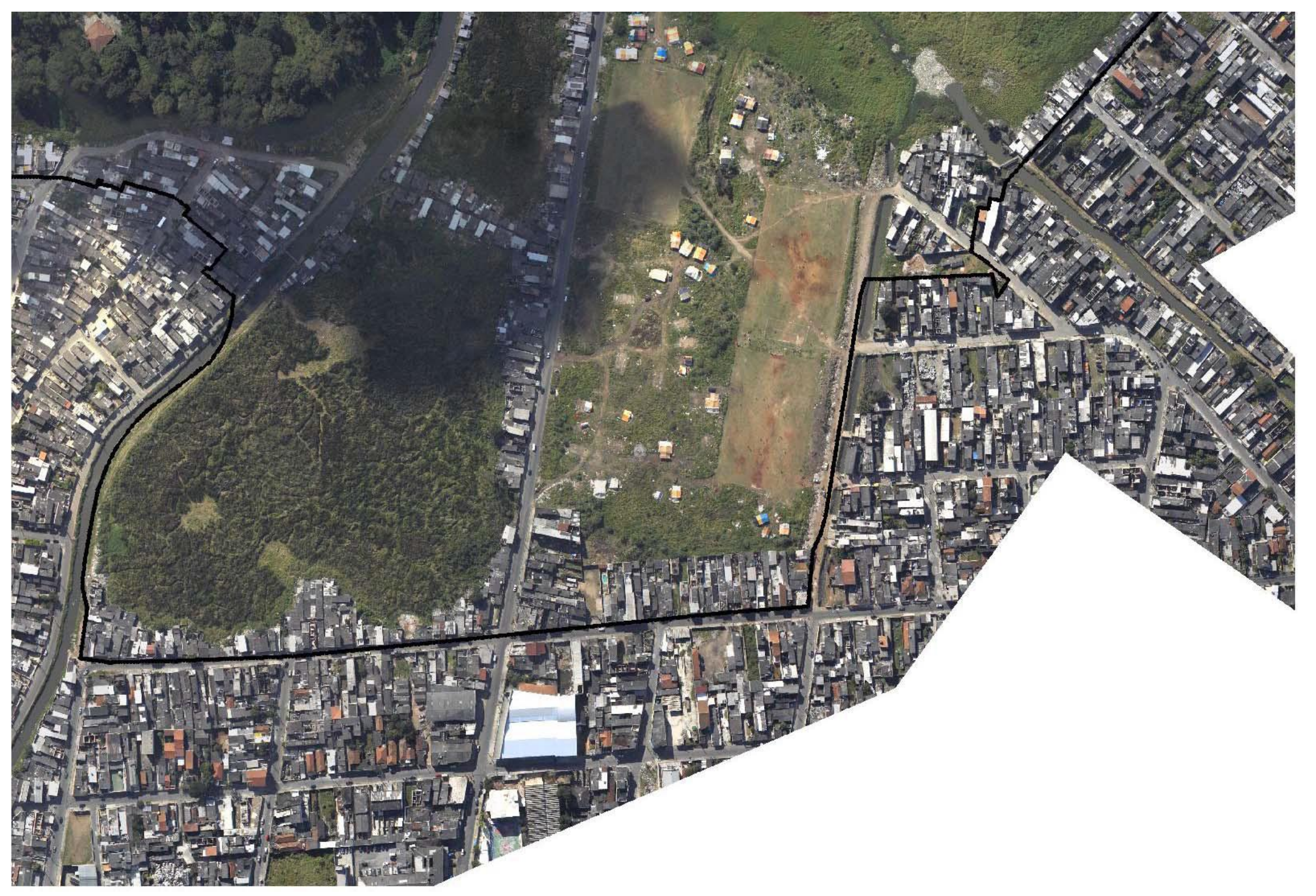




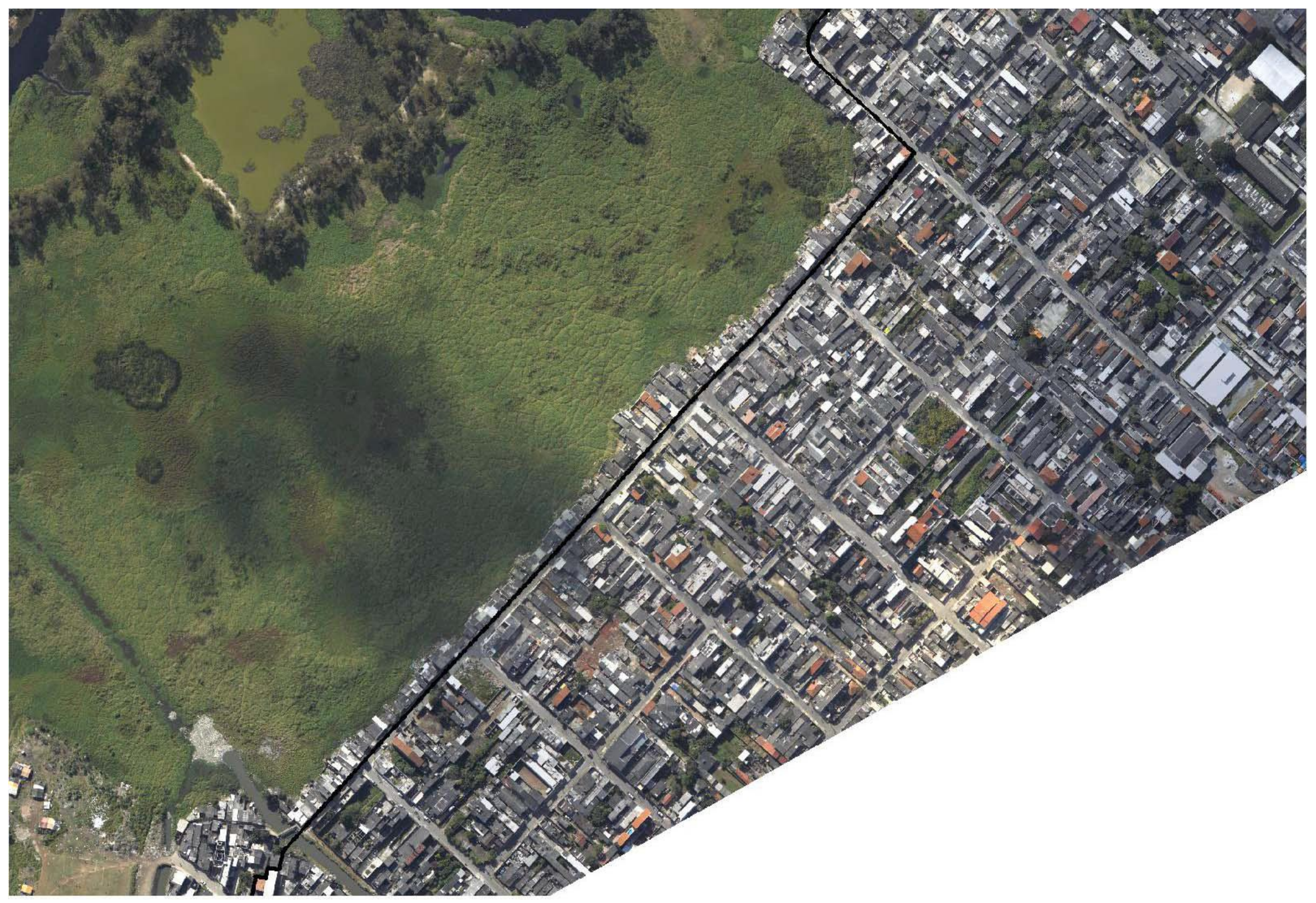




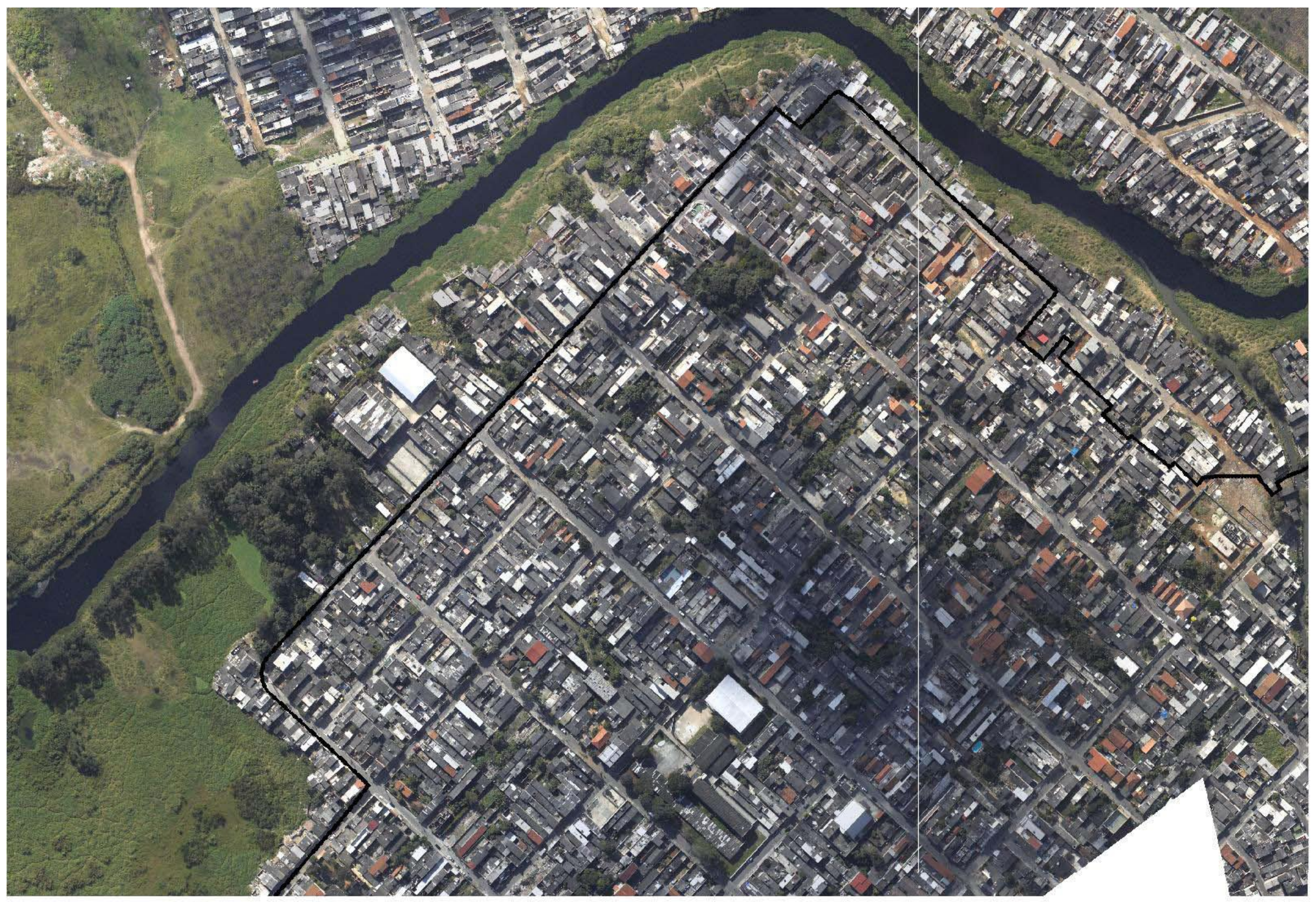




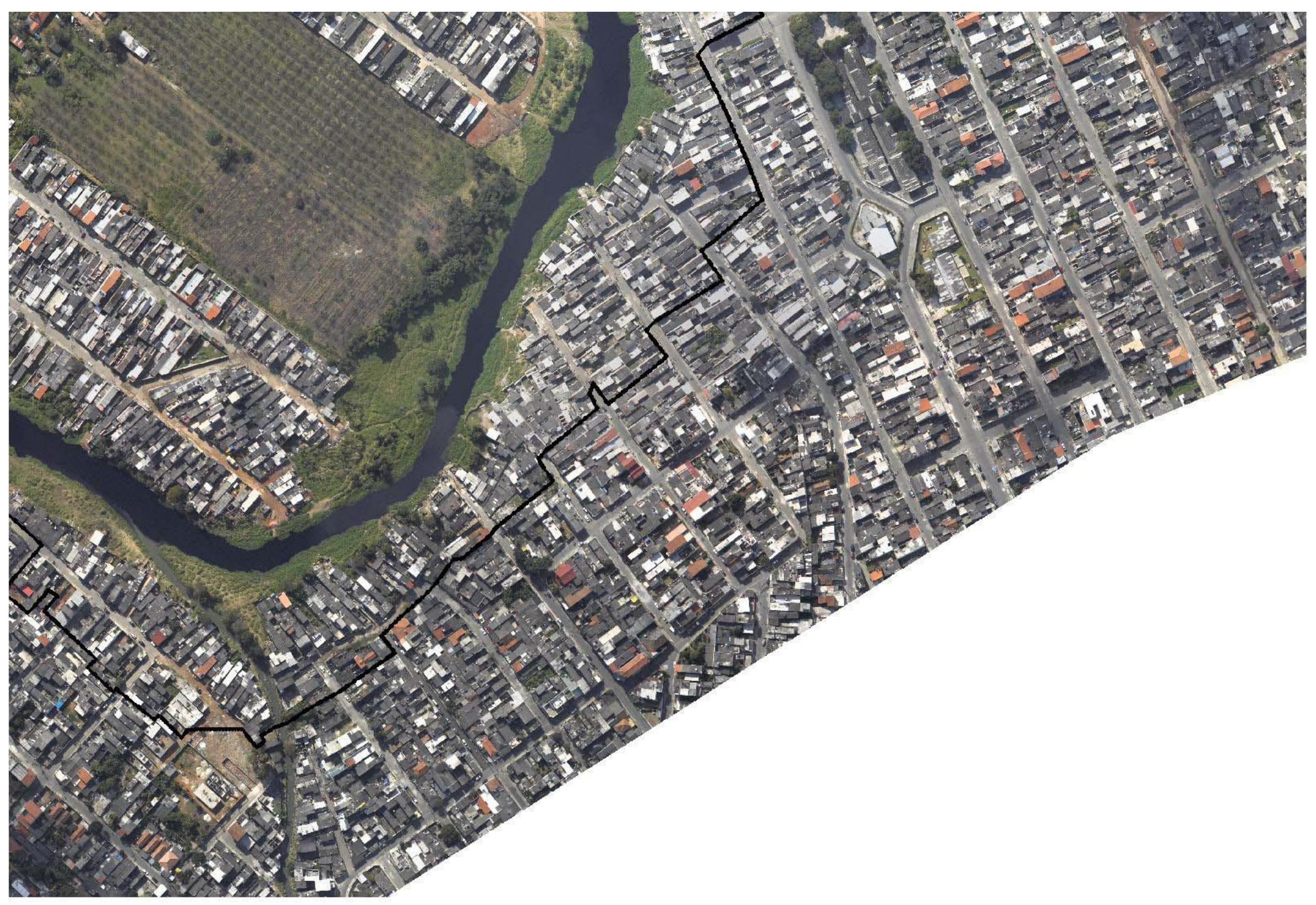




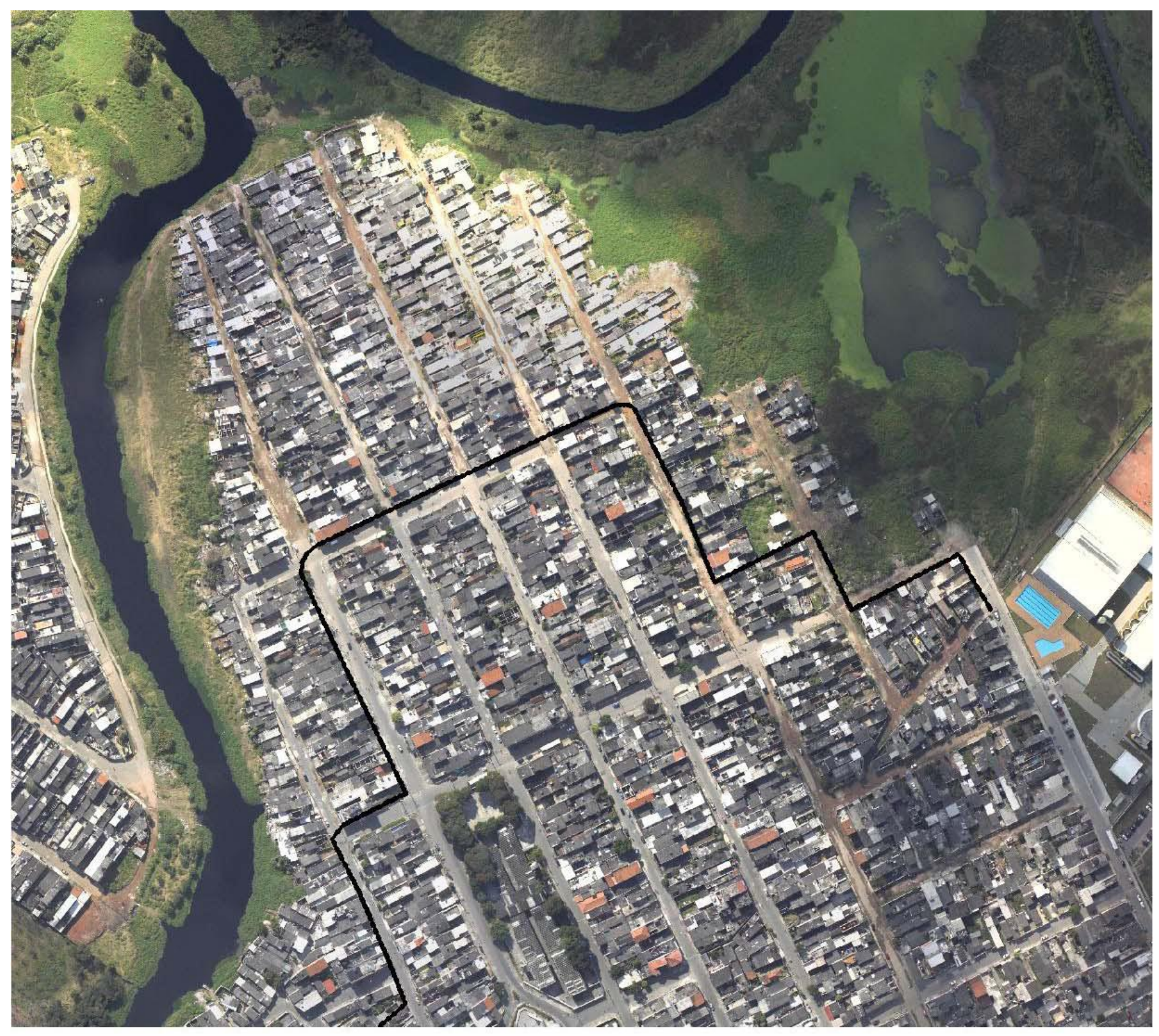


Anexo 3

Relatórios Banco Interamericano de Desenvolvimento (BID)

Operação BR - L1216 


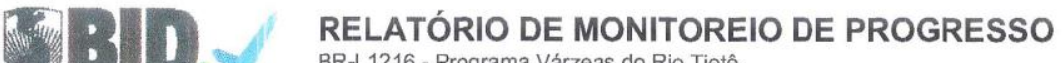 \\ BR-L1216 - Programa Várzeas do Rio Tieté}

$20122^{\circ}$ periodo com fechamento em (7-Mai-2013)
Banco Interamericano de Desenvolvimento - IDB Escritório de Planejamento Estratégico e Efetividade no Desenvolvimento Ültima Atualizaçăo do PMR: 01/04/2013

Relatório Resumido

$\begin{array}{lll}\text { Dados Gerais } & \text { Fundos Disponiveis (US\$) } \\ \text { Executor: } & \text { SECRETARIA DE ENERGIA Y SANEAMIENTO DEL ESTADO DE SAN PABLO }\end{array}$

$\begin{array}{ll}\text { Dados Gerais } & \text { Fundos Disponiveis (US\$) } \\ \text { Executor: } & \text { SECRETARIA DE ENERGIA Y SANEAMIENTO DEL ESTADO DE SAN PABLO }\end{array}$

Setor: WATER AND SANITATION

Estágio:

Tipo Operaçăo:

Operação Relacionada

Approved Desembolsado:

INV - Investimento \% Desembolsado

ESP - Specific Investment Operation

Custo Total e Fonte

Subtipo de Operação:

Reformulaçăo

$15.700 .000,00$ Original BID:

Corrente BID:

$115.700 .000,00$

Original Estimado:

$0.000,00$

$88,000.0000,00$

Validação

Categoria do impacto social:

A ( ) Os objetivos do projeto foram reformulados?

Validado pelo Chefe de Divisăo:

(9.78.

234
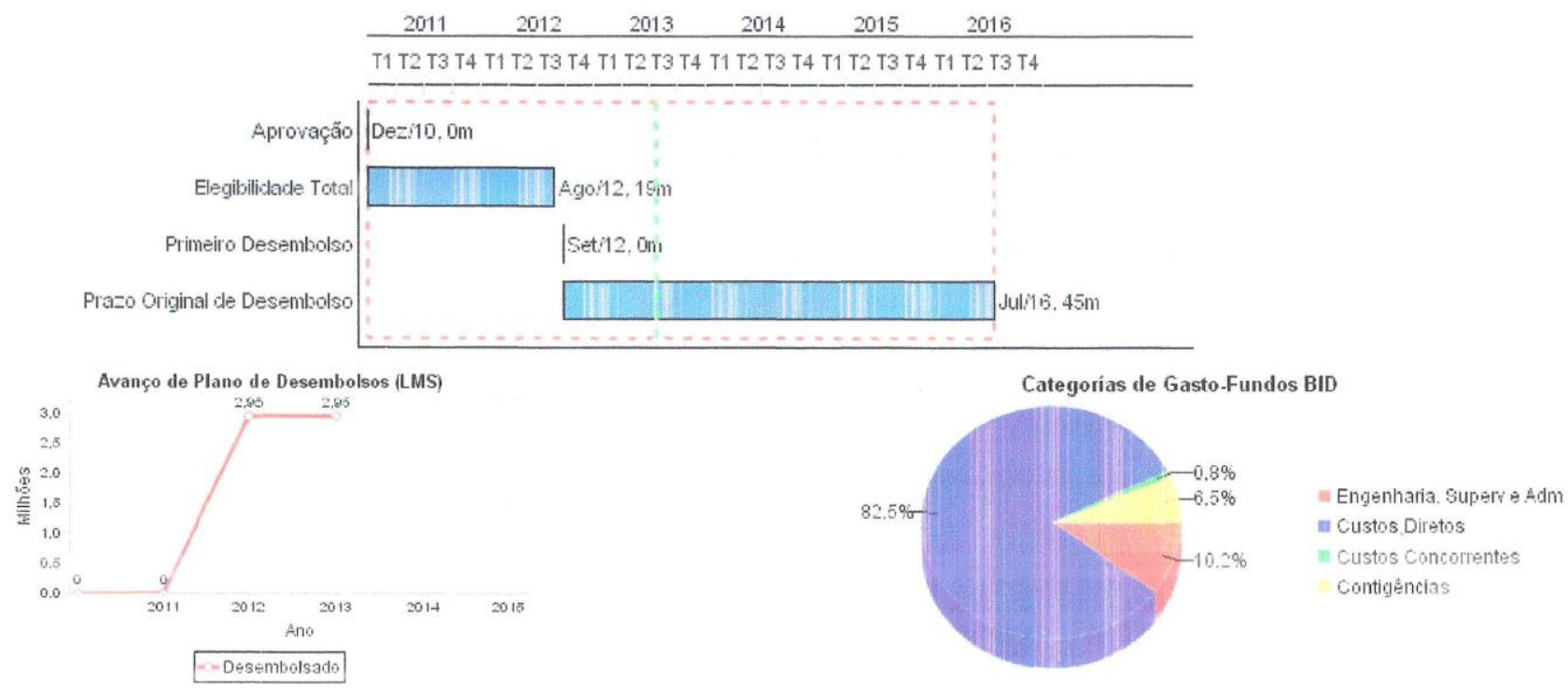


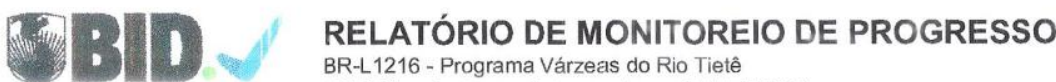

$20122^{\circ}$ periodo com fechamento em (7-Mai-2013)

Progresso Acumulado até 2012

Progresso Acumulado

1- Espaço de Convivência Jar di..

2 - Fannilizs reassemtadas com a..

$2,50 \%$

3 - Aterros mas áreas cle várzea

4- Desapropriaçöes (DUP / Desa.

5 - Ciclovias implantadas $41,02 \%$

6 - Plano de Gestäo do Parque .

7- Redes Coletoras construidas

8. Vias parque implantadas $41.67 \%$

9 - Espaço de Convivència Jardi.

10 - Obras de canalizą̧äo e prot

11 - Espaco de Convivência train

12 - Matas Ciliares recompostas

13 - Eventos de Educaçằ Ambient...

Financiamento BID $2.55 \%$

Calenćrio do Projeto HX

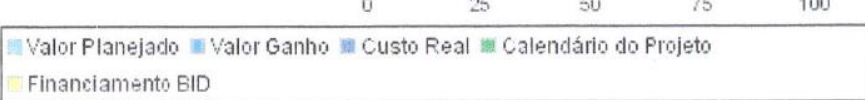

Banco Interamericano de Desenvolvimento - IDB Escritório de Planejamento Estategco e Efetividade no Desenvolvimento Última Atualizaçâu do PMR: 01/04/201 


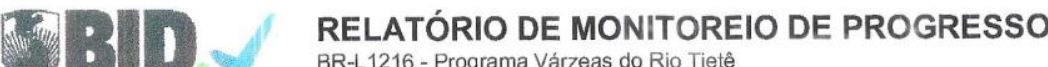 BR-L1216 - Programa Várzeas do Rio Tietê
$20122^{\circ}$ periodo com fechamento em (7-Mai-2013}

Banco Interamericano de Desenvolvimento - IDB

Escritório de Planejamento Estratégico e Efetividade no Desenvolvimento Ullima Atualizaçăă do PMR: 01/04/2013

\section{Resultados}

\begin{tabular}{|c|c|c|c|c|c|c|c|c|c|c|}
\hline \multicolumn{11}{|c|}{ Capacidade de retenção de água no trecho superior da bacia do rio Tietê ampliada } \\
\hline Indicador & Unidade Medida & $\begin{array}{c}\text { Linha } \\
\text { Base }\end{array}$ & $\begin{array}{c}\text { Ano Linha } \\
\text { Base }\end{array}$ & & 2011 & 2012 & 2013 & 2014 & 2015 & $\begin{array}{l}\text { Final do } \\
\text { Projeto }\end{array}$ \\
\hline $\begin{array}{l}\text { Tempo de retençăo das águas no trecho superior da } \\
\text { bacia do rio Tietê }\end{array}$ & Horas & 12,00 & 2010 & $\begin{array}{l}\mathrm{P} \\
\mathrm{A}\end{array}$ & 12,00 & $\begin{array}{l}12,00 \\
12,00\end{array}$ & 12,00 & 13,00 & 14,00 & 14,00 \\
\hline $\begin{array}{l}\text { Capacidade de retençăo de águas no trecho superior } \\
\text { da bacia do rio Tietê }\end{array}$ & $1.000 .000 \mathrm{~m} 3$ & & 2011 & $\begin{array}{l}\mathrm{P} \\
\mathrm{A}\end{array}$ & & $\begin{array}{l}0,80 \\
0,80\end{array}$ & 1,30 & 1,80 & 2,40 & 2,80 \\
\hline \multicolumn{11}{|c|}{\begin{tabular}{|l|l} 
Resultado: & Op̧̧öes de recreaçăo na área do projeto incrementadas \\
\end{tabular}} \\
\hline Indicador & Unidade Medida & $\begin{array}{l}\text { Linha } \\
\text { Base }\end{array}$ & $\begin{array}{c}\text { Ano Linha } \\
\text { Base }\end{array}$ & & 2011 & 2012 & 2013 & 2014 & 2015 & $\begin{array}{l}\text { Final do } \\
\text { Projeto }\end{array}$ \\
\hline População beneficiada com opçōes de recreação. & $\begin{array}{l}\text { milhares de } \\
\text { habitantes }\end{array}$ & 50,00 & 2010 & $\begin{array}{l}\mathrm{P} \\
\mathrm{A}\end{array}$ & 50,00 & $\begin{array}{l}50,00 \\
50,00\end{array}$ & 50,00 & 60,00 & 80,00 & 80,00 \\
\hline
\end{tabular}




\section{(10ituy : I I RELATÓRIO DE MONITOREIO DE PROGRESSO}

$20122^{\circ}$ período com fechamento em (7-Mai-2013)
Banco Interamericano de Desenvolvimento - IDB Escritório de Planejamento Estratégico e Efetividade no Desenvolvimento IItima Atualizaçâo do PMR: 01/04/2013

\section{Produtos: Progresso Físico e Financeiro Anual 2012}

\begin{tabular}{|c|c|c|c|c|c|c|c|c|c|}
\hline \multirow[b]{2}{*}{ Descrição } & \multirow{2}{*}{$\begin{array}{l}\text { Unidade } \\
\text { de medida }\end{array}$} & \multicolumn{4}{|c|}{ Fisico } & \multicolumn{4}{|c|}{ Financeiro } \\
\hline & & Planejado & Atual & $\begin{array}{l}\text { Unidades } \\
\text { Acumuladas }\end{array}$ & $\begin{array}{l}\text { Unidades } \\
\text { FDP }\end{array}$ & Planejado & Atual & $\begin{array}{l}\text { Custos } \\
\text { Acumulados }\end{array}$ & Custos FDP \\
\hline \multicolumn{10}{|l|}{ OBRAS } \\
\hline $\begin{array}{l}\text { Obras de canalizaçăo e proteçăo de cursos } \\
\text { d'água executadas }\end{array}$ & metro & & & & $2.000,00$ & & & & $11.523 .000,00$ \\
\hline Redes Coletoras construídas & metro & & & & $18.000,00$ & & & & $4.212 .000,00$ \\
\hline Aterros nas áreas de várzeas removidos & $1.000 .000 \mathrm{~m} 3$ & & & & $1.150,00$ & & & & $17.689 .000,00$ \\
\hline $\begin{array}{l}\text { Espaço de Convivência Jardim Helena } \\
\text { construído }\end{array}$ & $\begin{array}{l}\text { Espaço de } \\
\text { Convivência }\end{array}$ & & & & 1,00 & & & & $19.902 .000,00$ \\
\hline $\begin{array}{l}\text { Espaço de Convivência Itaim Biacica } \\
\text { construído }\end{array}$ & $\begin{array}{l}\text { Espaço de } \\
\text { Convivência }\end{array}$ & & & & 1,00 & & & & $13.048 .000,00$ \\
\hline $\begin{array}{l}\text { Espaço de Convivência Jardim Any Jaci } \\
\text { construído }\end{array}$ & $\begin{array}{l}\text { Espaço de } \\
\text { Convivência }\end{array}$ & & & & 1,00 & & & & $11.457 .000,00$ \\
\hline Vias parque implantadas & kilômetro & & & & 48,00 & & & & $15.418 .000,00$ \\
\hline Ciclovias implantadas & kilômetro & & & & 48,00 & & & & $6.608 .000,00$ \\
\hline \multicolumn{10}{|l|}{ REASSENTAMENTO } \\
\hline $\begin{array}{l}\text { Desapropriaçōes (DUP / Desap. Administrativa } \\
\text { ) executadas }\end{array}$ & $\mathrm{m}^{2}$ & & & & $1.081 .172,00$ & & & & $30.657 .000,00$ \\
\hline Famílias reassentadas com atendimento social & Domicilios & & & & 500,00 & & & & $20.020 .000,00$ \\
\hline \multicolumn{10}{|l|}{ SUSTENTABILIDADE AMBIENTAL E SOCIAL } \\
\hline Matas Ciliares recompostas & hectares & & & & 72,00 & & & & $14.954 .000,00$ \\
\hline Plano de Gestão do Parque implantado & plano & 0,35 & & & 1,35 & & & & $1.498 .000,00$ \\
\hline Eventos de Educaçăo Ambiental realizados & evento & & & & 15,00 & & & & $2.168 .000,00$ \\
\hline \multicolumn{10}{|l|}{ OUTROS } \\
\hline Estudos e Projetos & N/A & & & & & $159.000,00$ & & & $7.594 .000,00$ \\
\hline Gerência e Supervisăo & N/A & & & & & $2.420 .000,00$ & $1.392 .000,00$ & & $22.132 .000,00$ \\
\hline Avaliação & N/A & & & & & & & & $450.000,00$ \\
\hline Auditoria Financeira do Programa & N/A & & & & & & & & $450.000,00$ \\
\hline $\begin{array}{l}\text { Custos concorrentes, contigenciais e custos } \\
\text { financeiros }\end{array}$ & N/A & & & & & & & & \\
\hline \multicolumn{6}{|l|}{ (1) } & $2.579 .000,00$ & $1.392 .000,00$ & & $199.780 .000,00$ \\
\hline
\end{tabular}




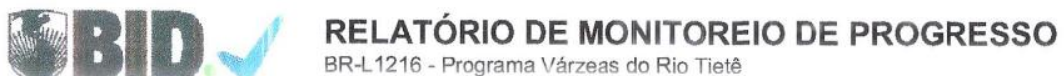

BR-L1216 - Programa Várzeas do Rio Tietê
$20131^{10}$ periodo com fechamento em (31-Out-2013)
Banco Interamericano de Desenvolvimento - IDB Escritório c'e Planejamento Estratécico e Efetividac's no Desenvolvimento Última Atualizaçăo do PMR: 26/09/2013

\section{Relatório Resumido}

Dados Gerais

Executci.

Setor:

Estágio:

Tipo Operaçăo:

Operaçăo Relacionada:

Subtipo de Operaçăo:

SECRETARIA DE ENERGIA Y SANEAMIENTO DEL ESTADO DE SAN PABLO

ESP - Specific Investment Operation

2500/OC-BR Atu

Approved Desembolsado:

esembolsado:

Categoria do impacto socia:

\section{Reformulação}

A ( ) Os objetivos do projeto foram reformulados?
Custo Total e Fonte

115.700.000,00 Original BID:

6.686.963,00 Corrente BID:

109.78 2 Pari-passu:

Cofinanciamento/P Período de Amortizaçăo (meses)
$115700,000,00$

$84.080 .000,00$ 234

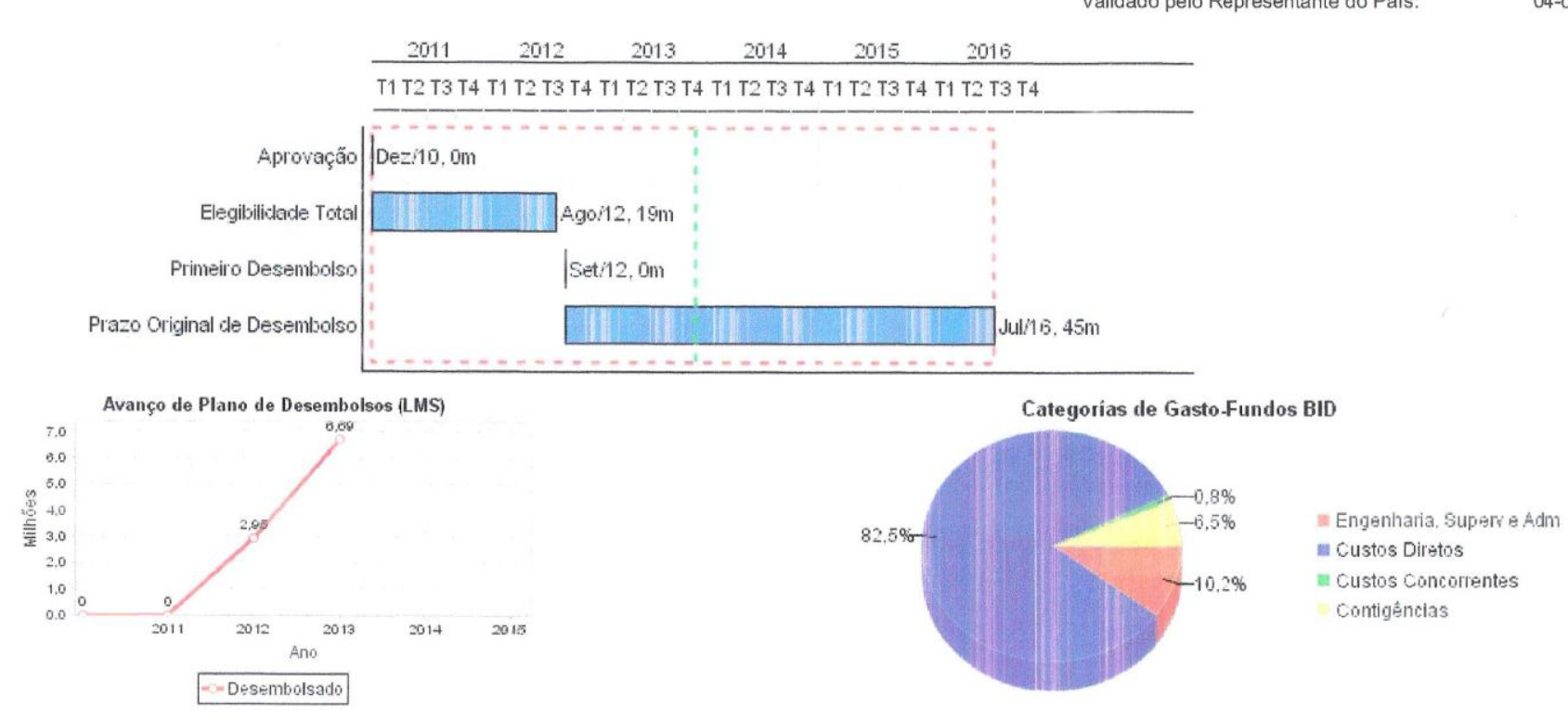




\section{(14ix) : I I RELATÓRIO DE MONITOREIO DE PROGRESSO}

BR-L1216 - Programa varzzas do Rio Tietée
$20131^{\circ}$ periodo com fechamento em (31-Out-2013)

Progresso Acumulado até 2013

Progresso Acumulado

1 - Espą̧̧ de Convivencia Jar di...

2 - Famúlias reassentadlas com a... 2, 2,002

3 - Aterros mas áreas de várzea-

4- Desapropriaçōes (Dup / Desa...

5 - Ciclovias implantadas

- Plano de Gestäo do Parque

7-Redes Coletoras construidas

8. Vias parque implantadas

9 - Espaço de Convivència Jardî.

10 - Obras de canalizaçäo e prot.

11 - Espaço de Convivència ttaim.

12 - Matas Ciliares recompostas

13 - Eventos de Educaçăo Ambient...

Financiamento BID

$5.78 \%$

Calendário do Projeto

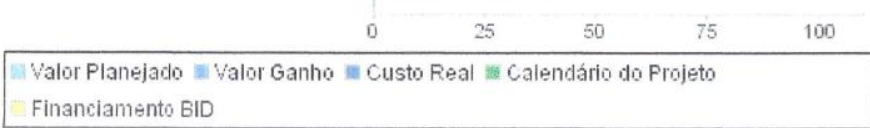

Banco Interamericano de Desenvolvimento - IDB Escritório cie Planejamento Estałégico e Efetividaça no Desenvolvimento Última Atualizaçăo do PMR: 26/09/2013 


\section{(40:14y) : 11 RELATÓRIO DE MONITOREIO DE PROGRESSO}

Banco Interamericano de Desenvolvimento - IDB $20131^{\circ}$ periodo com fechamento em (31-Out-2013)

Escritório ce Planejamento Estratégico e Efetividaća no Desenvolvimente Ullima Atualizaço do PMR: $26 / 09 / 2013$

\section{Resultados}

Resultado: $\quad$ Capacidade de retenção de água no trecho superior da bacia do rio Tietê ampliada

\begin{tabular}{|c|c|c|c|c|c|c|c|c|c|c|}
\hline Indicador & Unidade Medida & $\begin{array}{l}\text { Linha } \\
\text { Base }\end{array}$ & $\begin{array}{c}\text { Ano Linha } \\
\text { Base }\end{array}$ & & 2011 & 2012 & 2013 & 2014 & 2015 & $\begin{array}{l}\text { Final do } \\
\text { Projeto }\end{array}$ \\
\hline $\begin{array}{l}\text { Tempo de retençăo das águas no trecho superior da } \\
\text { bacia do rio Tietê }\end{array}$ & Horas & 12,00 & 2010 & $\begin{array}{l}\text { P } \\
\text { A }\end{array}$ & 12,00 & $\begin{array}{l}12,00 \\
12,00\end{array}$ & 12,00 & 13,00 & 14,00 & 14,00 \\
\hline $\begin{array}{l}\text { Capacidade de retenção de águas no trecho superior } \\
\text { da bacia do rio Tietê }\end{array}$ & $1.000 .000 \mathrm{~m} 3$ & & 2011 & $\begin{array}{l}\text { P } \\
\text { A }\end{array}$ & & $\begin{array}{l}0,80 \\
0,80\end{array}$ & 1,30 & 1,80 & 2,40 & 2,80 \\
\hline \multicolumn{11}{|c|}{\begin{tabular}{|l|l} 
Resultado: & Opções de recreação na área do projeto incrementadas
\end{tabular}} \\
\hline Indicador & Unidade Medida & $\begin{array}{l}\text { Linha } \\
\text { Base }\end{array}$ & $\begin{array}{c}\text { Ano Linha } \\
\text { Base }\end{array}$ & & 2011 & 2012 & 2013 & 2014 & 2015 & $\begin{array}{l}\text { Final do } \\
\text { Projeto }\end{array}$ \\
\hline População beneficiada com opções de recreaçăo. & $\begin{array}{l}\text { milhares de } \\
\text { habitantes }\end{array}$ & 50,00 & 2010 & $\begin{array}{l}P \\
A\end{array}$ & 50,00 & $\begin{array}{l}50,00 \\
50,00\end{array}$ & 50,00 & 60,00 & 80,00 & 80,00 \\
\hline
\end{tabular}




\section{4. : 1 RELATÓRIO DE MONITOREIO DE PROGRESSO}

BR-L1216 - Programa Várzeas do Rio Tietê
$20131^{\circ}$ período com fechamento em (31-Out-2013)
Banco Interamericano de Desenvolvimento - IDB Escritório de Planejamento Estratécico e Efetividada no Desenvolvimento Última Atualizaçăo do PMR: 26/09/2013

Produtos: Progresso Físico e Financeiro Anual 2013

\begin{tabular}{|c|c|c|c|c|c|c|c|c|c|}
\hline \multirow[b]{2}{*}{ Descrição } & \multirow{2}{*}{$\begin{array}{l}\text { Unidade } \\
\text { de medida }\end{array}$} & \multicolumn{4}{|c|}{ Fisico } & \multicolumn{4}{|c|}{ Financeiro } \\
\hline & & Planejado & Atual & $\begin{array}{l}\text { Unidades } \\
\text { Acumuladas }\end{array}$ & $\begin{array}{l}\text { Unidades } \\
\text { FDP }\end{array}$ & Planejado & Atual & $\begin{array}{c}\text { Custos } \\
\text { Acumulados }\end{array}$ & Custos FDP \\
\hline \multicolumn{10}{|l|}{ OBRAS } \\
\hline $\begin{array}{l}\text { Obras de canalização e proteção de cursos } \\
\text { d'água execuladas }\end{array}$ & metro & & & & $2.000,00$ & & & & $11.523 .000,00$ \\
\hline Redes Coletoras construídas & metro & & & & $18.000,00$ & & & & $4.212 .000,00$ \\
\hline Aterros nas áreas de várzeas removidos & $1.000 .000 \mathrm{~m} 3$ & 50,00 & & & $1.150,00$ & & & & $17.689 .000,00$ \\
\hline $\begin{array}{l}\text { Espaço de Convivência Jardim Helena } \\
\text { construído }\end{array}$ & $\begin{array}{l}\text { Espaço de } \\
\text { Convivência }\end{array}$ & & & & 1,00 & & & & $19.902 .000,00$ \\
\hline $\begin{array}{l}\text { Espaço de Convivência Itaim Biacica } \\
\text { construido }\end{array}$ & $\begin{array}{l}\text { Espaço de } \\
\text { Convivência }\end{array}$ & & & & 1,00 & & & & $13.048 .000,00$ \\
\hline $\begin{array}{l}\text { Espaço de Convivência Jardim Any Jaci } \\
\text { construído }\end{array}$ & $\begin{array}{l}\text { Espaço de } \\
\text { Convivência }\end{array}$ & & & & 1,00 & & & & $11.457 .000,00$ \\
\hline Vias parque implantadas & kilômetro & 13,00 & & & 48,00 & $6.425 .000,00$ & & & $15.418 .000,00$ \\
\hline Ciclovias implantadas & kilômetro & 13,00 & & & 48,00 & $2.750 .000,00$ & & & $6.608 .000,00$ \\
\hline \multicolumn{10}{|l|}{ REASSENTAMENTO } \\
\hline $\begin{array}{l}\text { Desapropriações (DUP / Desap. Administrativa } \\
\text { ) executadas }\end{array}$ & $\mathrm{m}^{2}$ & $500.000,00$ & & & $1.081 .172,00$ & $8.500 .000,00$ & & & $30.657 .000,00$ \\
\hline Familias reassentadas com atendimento social & Domicilios & & & & 500,00 & $500.000,00$ & & & $20.020 .000,00$ \\
\hline \multicolumn{10}{|l|}{ SUSTENTABILIDADE AMBIENTAL E SOCIAL } \\
\hline Matas Ciliares recompostas & hectares & & & & 72,00 & & & & $14.954 .000,00$ \\
\hline Plano de Gestão do Parque implantado & plano & & & & 1,35 & & & & $1.498 .000,00$ \\
\hline Eventos de Educação Ambiental realizados & evento & & & & 15,00 & $434.000,00$ & & & $2.168 .000,00$ \\
\hline \multicolumn{10}{|l|}{ OUTROS } \\
\hline Estudos e Projetos & N/A & & & & & $4.153 .000,00$ & & & $7.594 .000,00$ \\
\hline Gerência e Supervisăo & N/A & & & & & $6.714 .000,00$ & $1.733 .000,00$ & & $22.132 .000,00$ \\
\hline Avaliação & N/A & & & & & & & & $450.000,00$ \\
\hline Auditoria Financeira do Programa & N/A & & & & & $135.000,00$ & & & $450.000,00$ \\
\hline $\begin{array}{l}\text { Custos concorrentes, contigenciais e custos } \\
\text { financeiros }\end{array}$ & N/A & & & & & & & & \\
\hline & TOTAL & & & & & $29.611 .000,00$ & $1.733 .000,00$ & & $199.780 .000,00$ \\
\hline
\end{tabular}




\section{Anexo 4}

Mapa das Remoções

Município de São Paulo 


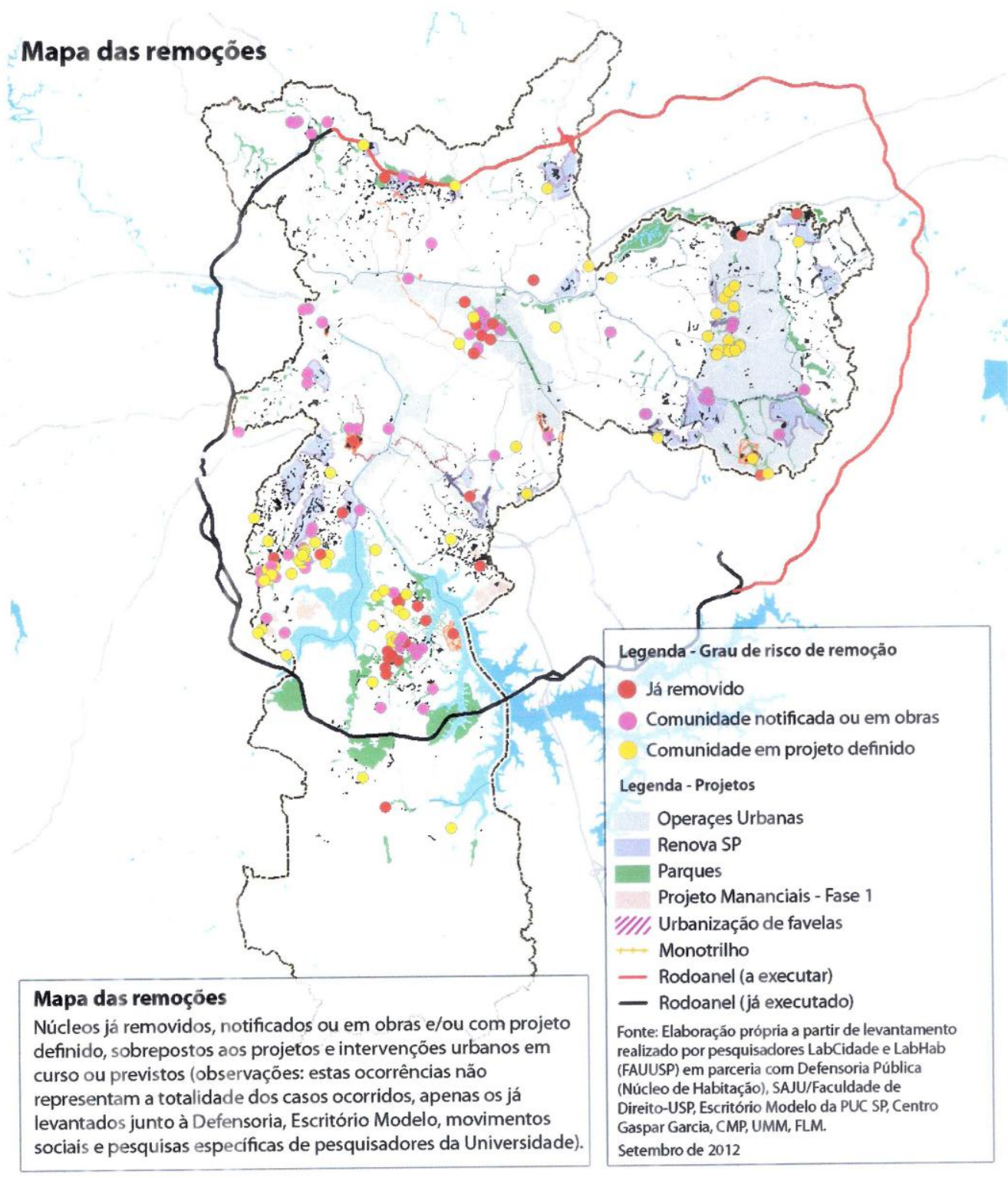

